\title{
Kwaliteit van klinisch onderwijs
}

Citation for published version (APA):

Wolfhagen, H. A. P. (1993). Kwaliteit van klinisch onderwijs. [Doctoral Thesis, Maastricht University]. Datawyse / Universitaire Pers Maastricht. https://doi.org/10.26481/dis.19930218hw

Document status and date:

Published: 01/01/1993

DOI:

10.26481/dis.19930218hw

Document Version:

Publisher's PDF, also known as Version of record

\section{Please check the document version of this publication:}

- A submitted manuscript is the version of the article upon submission and before peer-review. There can be important differences between the submitted version and the official published version of record.

People interested in the research are advised to contact the author for the final version of the publication, or visit the DOI to the publisher's website.

- The final author version and the galley proof are versions of the publication after peer review.

- The final published version features the final layout of the paper including the volume, issue and page numbers.

Link to publication

\footnotetext{
General rights rights.

- You may freely distribute the URL identifying the publication in the public portal. please follow below link for the End User Agreement:

www.umlib.nl/taverne-license

Take down policy

If you believe that this document breaches copyright please contact us at:

repository@maastrichtuniversity.nl

providing details and we will investigate your claim.
}

Copyright and moral rights for the publications made accessible in the public portal are retained by the authors and/or other copyright owners and it is a condition of accessing publications that users recognise and abide by the legal requirements associated with these

- Users may download and print one copy of any publication from the public portal for the purpose of private study or research.

- You may not further distribute the material or use it for any profit-making activity or commercial gain

If the publication is distributed under the terms of Article $25 \mathrm{fa}$ of the Dutch Copyright Act, indicated by the "Taverne" license above, 


\section{KWALITEIT VAN KLINISCH ONDERWIJS}

\section{Proefschrift}

ter verkrijging van de graad van doctor

aan de Rijksuniversiteit Limburg te Maastricht, op gezag van de Rector Magnificus, Prof. mr. M.J. Cohen, volgens het besluit van het College van Dekanen, in het openbaar te verdedigen op donderdag,

18 februari 1993 om 16.00 uur

door

Hubertina Antoinette Petronella Wolfhagen

geboren te Roermond in 1957 


\section{Promotores:}

Prof. dr. G.G.M. Essed

Prof. dr. H.G. Schmidt

\section{Beoordelingscommissie:}

Prof. dr. J.J.C.B. Bremer (voorzitter)

Prof. dr. B.P.M. Creemers (Rijksuniversiteit Groningen)

Prof. dr. G. Kootstra

Prof. dr. J.C.M. Metz (Katholieke Universiteit Nijmegen)

Prof. dr. W.H.F.W. Wiinen

Omslagontwerp en vormgeving: af bv

Drukwerk: Datawyse / Universitaire Pers Maastricht

CIP-gegegevens Koninklijke Bibliotheek, Den Haag

Wolfhagen, Hubertina Antoinetta Pertonella

Kwaliteit van klinisch onderwijs / Hubertina Antoinetta Petronella Wolfhagen. - Maastricht: Universitaire Pers Maastricht. - III.

Proefschrift Maastricht. - Met lit. opg. - Met samenvatting in het Engels.

ISBN 90-5278-052-8

NUGI 724

Trefw.: geneeskunde-onderwijs; Nederland; onderzoek. 
Quality.... you know what it is, yet you don 't know what it is. Butt that's selfcontradictory. But some things are better than others. That is, they have more quality. But when you try to say what that quality is, apart from the things that have it, it all goes poof! There's nothing to talk about. But if you can 't say what quality is, how do you know that it even exists? If no one knows what it is, then for all practical purposes it doesn't exist at all. But for all practical purposes it does exist. What else are the grades based upon? Why else would people pay fortunes for some things and throw others in the trash pile? Obviously, some things are better than others..... but what's the "betterness"?.... So round and round you go, spinning mental wheels and nowhere finding any place to get traction. What the hell is Quality? What is it? (Bron: Pirsig geciteerd bij Conrad en Blackburn, 1985, p. 284) 


\section{INHOUDSOPGAVE}

$\begin{array}{ll}\text { Voorwoord } & 7\end{array}$

1. Inleiding 9

2. Het medisch onderwijs 13

2.1 Ontwikkeling van het medisch onderwijs in Nederland 13

2.2 Internationale ontwikkelingen 24

2.3 Medisch onderwijs in discussie 27

2.4 Samenvatting 31

3. Opbouw van de studie geneeskunde te Maastricht 33

3.1 Basisfilosofie van de Medische Faculteit Maastricht 34

3.2 Opzet van de eerste vier studiejaren 35

3.3 Opzet van studiejaar 5 en $6 \quad 37$

3.4 Samenvatting 43

4. Evaluatie van co-assistentschappen 45

4.1 Typering van de onderwijsorganisatie en
de visie op onderwijs

4.2 Kwaliteit van stages gemeten 51

4.3 Samenvatting 54

5. Constructie van het meetinstrument 55

5.1 Omschrijving van voorwaarden 55

5.2 Evaluatievorm 64

5.3 Pilotstudy 66

5.4 Beschrijving van het instrument 67

$\begin{array}{ll}5.5 \text { Samenvatting } & 72\end{array}$

6. Interpretatie van evalualiegegevens 73

6.1 Interpretatie van gegevens: een inleiding 73

6.2 Normen 76

6.2.1 Absolute normen 76

6.2.2 Relatieve normen 77

6.2 .3 Zelfgerichte normering 79

6.2.4 Samenvatting 79

6.3 Toepassing van normen in de praktijk 81

6.4 Samenvatting 86 
7. Stage-evaluatie in de praktijk 87

7.1 Inleiding 87

7.2 Creëren van een evaluatieklimaat 89

7.3 Innovatie in de praktijk 91

7.4 Praktiiksituaties 96

7.4. 1 Studie 1: Dermatologie in een affiliatieziekenhuis 96

7.4.2 Studie 2: Kindergeneeskunde in een affiliatieziekenhuis 98

7.4.3 Studie 3: Voorbereiding op de stage 102

7.5 Samenvatting

8. Validiteit van het instrument 105

8.1 Inleiding validiteit 105

8.2 Studie 4: Constructvaliditeit $\quad 107$

8.2.1 Inleiding 107

8.2.2 Methode 109

8.2.3 Resultaten 114

8.3 Studie 5: Invariantie van correlatiematrices $\quad 115$

8.3.1 Inleiding 115

8.3.2 Methode 115

8.3.3 Resultaten $\quad 116$

$\begin{array}{ll}8.4 \text { Samenvatting } & 117\end{array}$

9. Betrouwbaarheid van het instrument 119

9.1 Inleiding betrouwbaarheid 119

9.2 Generaliseerbaarheidstheorie 121

9.3 Studie 6: Generaliseerbaarheid over stages $\quad 129$

9.3.1 Analyseprocedure 129

9.3.2 Resultalen 129

9.4 Studie 7: Generaliseerbaarheid over stageplaatsen 132

9.4.1 Analyseprocedure 133

9.4.2 Resultaten 133

9.5 Studie 8: Generaliseerbaarheid over stageplaats 136

9.5.1 Analyseprocedure 136

9.5.2 Resultaten 137

9.6 Algemene conclusie 139

9.7 Samenvatting 141

10. Discussie en conclusies 143

Samenvatting 151

Summary 161

Biilagen $\quad 169$

$\begin{array}{ll}\text { Literatuurlijst } & 187\end{array}$

$\begin{array}{ll}\text { Curriculum vitae } & 207\end{array}$ 


\section{VOORWOORD}

Deze studie is verricht in het kader van het project programma-evaluatie van de Faculteit der Geneeskunde van de Rijksuniversiteit Limburg. De fundamenten voor het systematisch evalueren van co-assistentschappen werden in 1986 gelegd door de toenmalige medewerkers van het project programma-evaluatie. Zij verschaften mij de basis waarop ik kon voortbouwen. Dit proefschrift is hiervan het resultaat.

Bii de totstandkoming van dit proefschrift zijn verschillende personen betrokken geweest wier inbreng ik zeer heb gewaardeerd: mijn beide "eerste" promotores Prof. dr. G.G.M. Essed en Prof. dr. H.G Schmidt voor de stimulerende wijze waarop zii mij begeleid hebben;

Cees van der Vleuten en Wim Gijselaers voor de wijze waarop ze alle stadia van het onderzoek kritisch hebben gevolgd en becommentarieerd;

Riny Rondas van Bureau Onderwijs van de Faculteit der Geneeskunde voor de voortreffelijke wijze waarop ze zorgdraagt voor het secretariaat van het project programmaevaluatie en het grote aandeel in de vormgeving van het manuscripl;

studenten en stagecoördinatoren die ervoor gezorgd hebben dat "input" door middel van vragenlijsten omgezet kon worden in "output". Hun betrokkenheid geeft aan dat de kwaliteit van het onderwijs ook hun zorg is;

de leden van de beoordelingscommissie voor de plezierige wijze waarop zij nog enkele punties op de "i" hebben gezet.

Een woord van dank is ook zeker op zijn plaats voor alle mensen die achter de schermen deze dissertatie mede mogelijk hebben gemaakt. Hun inspanningen worden vaak als te vanzelfsprekend beschouwd. Zonder anderen te kort te willen doen noem ik: Diana Dolmans, Bert Kerkhofs, Diana Riksen, Monique Seuren, Margariet Scharnigg, Fons Voesten, Margriet de Weijer en Germa Wijnen. En verder wil ik een dankwoord richten aan Petra en Gerard Steffanie, collega's, vrienden en de "Ardennengangers". Tot slot wil ik degenen noemen aan wie ik dit proefschrift opdraag: mijn ouders.

Ineke Wolfhagen

februari 1993 
$-8$ 


\section{Inleiding}

Binnen het hoger onderwijs is altijd wel aandacht besteed aan de kwaliteit van onderwijs. Echter de mate waarin, en de wijze waarop was sterk afhankelijk van de individuele docent en het opleidingsinstituut. Pas de laatste jaren wordt in Nederland zowel in het wetenschappelijk onderwijs (WO) als in het hoger beroepsonderwijs ( $\mathrm{HBO}$ ) structurele en systematische aandacht gegeven aan kwaliteitsvraagstukken (Heijnen, Joostens \& Vroeijenstijn, 1990). Daar zijn verschillende redenen voor aan te geven. Vanaf het begin van de zestiger jaren nam het aantal studenten sterk toe, waardoor het onderwijs een steeds groter aandeel begon op te eisen van het nationaal budget. Deze groei van het hoger onderwijs leidde viteraard naar de vraag hoe efficiënt en effectief met de besteding van de middelen kon worden omgegaan. Ook de invoering van de Wet Twee-Fasenstructuur (1979) en de Wet op het Wetenschappelijk Onderwijs (1981) riepen de vraag op of het mogelijk is binnen de gestelde randvoorwaarden kwaliteit te leveren. Voorts is er de laakste jaren een verschuiving waarneembaar van een centraal bestuurd hoger onderwijs naar een grotere autonomie voor de instellingen voor hel hoger onderwijs. De overheid verwoordde haar nieuwe filosofie met betrekking tot het hoger onderwijs in de nota "Hoger onderwijs autonomie en kwaliteit" (HOAK, 1985) en de nota "Hoger onderwijs onderzoek plan" (HOOP, 1987). Daarin beloofde zij terug le treden en de universiteiten meer autonomie en een grotere programmeervrijheid te geven op voorwaarde dat de kwaliteit gewaarborgd bleef. Op basis van deze "sturing op afstand" kriigen de instellingen van de overheid meer zelfstandigheid, mits deze achteraf verantwoording afleggen over de inzet van financiële en materiële middelen in relatie tot de gerealiseerde produktie. Het hoger onderwijs stelde vitdrukkelijk dat de kwaliteit van hel onderwijs een aangelegenheid moet zijn van de instituten zelf. Dit resulteerde in de beslissing van de minister om de instellingen in beginsel zelf verantwoordelijk te stellen voor de kwaliteit van het onderwijs, waarbij zij zorg dienen te dragen voor kwaliteirsbewaking door middel van interne en externe evaluatie. 
De overheid heeft daarnaast een eigen verantwoordelijkheid met betrekking to de kwaliteitsbewaking in het hoger onderwijs, in welk verband er een wettelijke taak is weggelegd voor de onderwijsinspectie. De inspectie heeft de taak toe te zien op de deugdelijkheid van het systeem: meta-evaluatie (Bresters, 1990; HO-overlegkamer, 1985 en 1986). De minister drong aan op eenzelfde sysleem voor kwaliteitszorg bij het $\mathrm{HBO}$ en het WO. Het $\mathrm{HBO}$ koos echter voor een systeem van kwaliteitszorg binnen de instelling: sectorale kwaliteitszorg. De universiteiten kozen ervoor de aandacht te richten op een landelijke aanpak. Deze aanpak was "faculteitsgericht" en gebaseerd op het werken mel visitafiecommissies (Vroeijenstijn, 1991). Hierbij wordt een onderscheid gemaakt in interne en externe kwaliteitszorg. Interne kwaliteitszorg is de systematische, gestructureerde aandacht, die binnen een instelling besteed wordt aan kwaliteitshandhaving en kwaliteitsverbetering. Hiervan wordt jaarlijks verslag gedaan in het universitaire onderwijsverslag (Bouhuijs, 1990; Inspectie hoger onderwijs, 1989). Externe kwaliteitszorg is de systematische en structurele aandacht voor de kwaliteit van het onderwijs waarbij commissies van externe deskundigen worden ingeschakeld. Een visitatiecommissie bestaande vit externe deskundigen voert de kwaliteitszorg uit. Het visitatiestelstel is gebaseerd op het besluit van de gezamenlijke universiteiten. Het Bestuurlijk Overleg van de Vereniging voor Nederlandse Universiteiten (VSNU) is de opdrachtgever van de visitatiecommissie, die echter worden ingesteld door het ministerie van Onderwijs en Wetenschappen. De visitatiecommissies maken onder meer gebruik van de zogenaamde "zelfstudie" die de instellingen schrijven. Het document behoort aspecten te behandelen die te maken hebben met de kwaliteit van het onderwijs in de betreffende discipline. Bij de samenstelling van de zelfstudie wordt gebruik gemaakt van het onderwijsverslag (VSNU, 1990). De koppeling van interne en externe kwaliteitszorg is sinds 1988 een nieuw verschijnsel dat binnen alle universiteiten zijn intrede heeft gedaan. De eerste visitaties van de medische faculteiten hebben plaatsgevonden in het najaar van 1991. Het rapport van de onderwijsvisitatie is in april 1992 verschenen (VSNU, 1992).

Een logisch gevolg van deze vraag naar informatie over de kwaliteit van het onderwijs is, dat binnen het hoger onderwijs behoefte was aan systemen die het mogelijk maken verantwoording af te leggen over de kwaliteit. De ontwikkeling van dergelijke systemen heeft de laatste jaren dan ook een grote vlucht genomen. Aan de Rijksuniversiteit Limburg, werd al geruime tijd voordat de kwaliteitszorg van onderwijs in Nederland actueel was, gewerkt aan de ontwikkeling van systemen voor kwaliteitszorg. Dat heeft een duidelijke oorzaak. In 1974 werd in Maastricht de achtste medische 
faculteit van Nederland opgericht. De opzet van hel onderwijs vindt plaats vanuit een probleemgestuurde benadering (Tiddens, Willighagen \& Wijnen, 1975; Schmidt, 1979). Deze onderwijsvorm wijkt af van de onderwijsstrategie van haar zusterfaculteiten. Dit betekende dat een geheel nieuw curriculum ontwikkeld diende le worden. Informatie over de kwaliteit van de programma's was daarom zeer gewenst. Daarenboven bestond een sterke behoefte om verantwoording over de kwaliteit van het onderwijs af te leggen aan derden zoals zuslerfaculteilen en de overheid. Vanaf 1974 werd daarom, zij het op bescheiden schaal, informatie verzameld, ter ondersteuning van de curriculumontwikkeling. Daarmee werd de basis gelegd voor een systematisch programma-evaluatie.

In 1982 werd door de toenmalige onderwijscommissie binnen de medische faculteit een werkgroep programma-evaluatie ingesteld met als doelstelling: evaluatie van het medische curriculum in de eerste vier studiejaren. Uitgangspunt was dat instrumenten, die ontwikkeld en toegepast zouden worden, een hoge praktische bruikbaarheid zouden moeten hebben. Dat wil zeggen dat het mogelijk moest zijn aan te geven welke aspecten van het onderwijs verbeterd moeten worden (Gijselaers \& Schmidt, 1990). Dit resulteerde in 1985 in de opzet van een gestandaardiseerd evaluatiesysteem voor de eerste vier studiejaren (Gijselaers, 1988). Pas later vond er een vitbreiding van evaluatieactiviteiten plaats naar het programma van studiejaar 5 en 6 . Gedurende deze twee jaren lopen de studenten stages binnen ziekenhuizen en diverse instellingen van de gezondheidszorg, de zogenaamde "co-assistentschappen". Co-assistentschappen vinden plaats op verschillende lokaties en in verschillende ziekenhuizen. Het onderwijsaanbod wordt, binnen bepaalde randvoorwaarden, grotendeels bepaald door de betreffende ziekenhuisafdelingen. Als gevolg van deze sterk gedecentraliseerde aanpak is het voor de faculteit moeilijk om controle uit te oefenen op de inrichting en vormgeving van de stages. Het onderwijs in de tweede fase ontrok zich daardoor grotendeels aan de invloed van de faculteit. Zeker gezien de belangrijke plaats die de co-assistentschappen binnen de totale opleiding tot basisarts innemen, vond de faculteit het belangrijk om meer inzicht te kriigen in de kwaliteit van stages om zonodig maatregelen ter verbetering te kunnen treffen. Dit resulteerde in 1986 in inititatieven om ook een systeem voor kwaliteitszorg voor de co-assistentschappen op te zetten. Enerzijds betekende dit de ontwikkeling van een evaluatiesysteem voor de extra-murale stages, huisartsgeneeskunde en het ambulante deel van de stage psychiatrie, en anderzijds voor de intra-murale co-assistentschappen.

Dit proefschrift beschrijft de ontwikkeling van een systeem voor kwaliteitszorg van de intra-murale stages. De stage huisartsge- 
neeskunde en de stage psychiatrie (zowel het ambulante als het klinische deel) blijven in deze studie buiten beschouwing. Zij zijn al eerder object van onderzoek geweest (Bouhuijs, 1983; Kraan \& Crijnen, 1987). De doelen van de in dit proefschrift te rapporteren studie kunnen als volgt geformuleerd worden:

1) de ontwikkeling van een instrument voor een valide en betrouwbare beoordeling van de kwaliteit van co-assistentschappen;

2) het creëren van voorwaarden voor de invoering van dit instrument in de onderwijspraktijk;

3) het bevorderen van het gebruik van het instrument en het op grond van empirische gegevens doen van voorstellen om het onderwijs te verbeteren.

Hieronder volgt een beknople karakterisering van de inhoud van de verschillende hoofdstukken. Hoofdstuk 2 beschrijft de geschiedenis van het medisch onderwijs, waarbij de belangrijkste ontwikkelingen de revue zullen passeren. Hoofdstuk 3 beschriift de opzet van het onderwijs aan de Medische Faculteit Maastricht. Speciale aandacht krijgt de inrichting van het klinisch onderwijs. Hoofdsfuk 4 beschrijft de organisatie van de co-assistentschappen. Daarbij wordt enerzijds een typering gegeven van het organisatieklimaat en anderzijds van de functie die docenten binnen het onderwijs vervullen. Voorts wordt in dit proefschrift aandacht besteed aan de gekozen evaluatiebenadering. Hoofdstuk 5 gaal in op de constructie van het evaluatie-instrument. De verschillende stappen in het constructieproces komen aan de orde. Allereerst volgt de operationalisering van het begrip kwaliteit. Vervolgens wordt aandacht besteed aan de vormgeving van het instrument. En tenslotte wordt het instrument beschreven. Het gebruik van de evaluatiegegevens vereist de berekening van scores voor de diverse kwaliteitsaspecten en de toekenning van een waardering hieraan. In hoofdstuk 6 komt de interpretatie van evaluatiegegevens aan de orde. Hoofdstuk 7 bespreekt de invoering van het instrument en illustreert de praktische toepassing aan de hand van een aantal voorbeelden. In de daaropvolgende twee hoofdstukken staan de meeteigenschappen van het instrument centraal. Hoofdstuk 8 bespreekt de validiteit van het instrument. Hoofdstuk 9 gaat in op de betrouwbaarheid, waarbii gebruik wordt gemaakt van de generaliseerbaarheidstheorie. In hoofdstuk 10 worden enkele afsluitende opmerkingen geplaatst. 


\section{Het medisch onderwijs}

De bevoegdheid tot het uitoefenen van de geneeskunde kan uitsluitend verkregen worden door het volgen van een universitaire opleiding. Dit is niet altijd zo geweest. Van oudsher waren er diverse opleidingsmogelijkheden om in het bezit te komen van een artsentitel. De artsentitels waren onderling niet vergelijkbaar waardoor er weinig eenheid in de beroepsuitoefening was. Deze situatie duurde totdat in 1865 de geneeskundige wetten van Thorbecke van kracht werden. Op dat moment is er sprake van één bevoegdheid en éen opleiding. Deze oorspronkelijke diversiteit in opleidingen heeft de organisatie en de opzet van het medisch onderwijs sterk beïnvloed. In dit hoofdstuk staat de historische ontwikkeling van dat onderwijs centraal. Paragraaf 2.1 beschrijft de geschiedenis van het medisch onderwijs in Nederland. Betoogd zal worden dat al enige honderden jaren lang kritische geluiden klinken over de inrichting van het medisch onderwijs. Na een periode van betrekkelijke stabiliteit na de Tweede Wereldoorlog wordt steeds duidelijker dat studenten onvoldoende toegerust zijn voor "de gezondheidszorg van de toekomst" en de opleiding aanpassing verdient. Niet alleen in Nederland zijn deze geluiden hoorbaar, maar ook elders in de wereld. In paragraaf 2.2 komt aan de orde op welke wijze het medisch onderwijs zou moeten veranderen. In paragraaf 2.3 volgt een beschrijving van de kritiek op het huidige medisch onderwijs en een beschrijving van recente vernieuwingen. Paragraaf 2.4 sluit af met een samenvatting.

\subsection{Ontwikkeling van het medisch onderwijs in Nederland}

In het verleden was er zowel sociaal als wetenschappelijk een scheiding tussen de universitair geschoolde doctores medicinae aan de ene, en de praktisch geschoolde heel- en vroedmeesters aan de andere kant. De doctores medicinae behoorden tot de gegoede stand en voelden zich verheven boven de chirurgijns, die meestal voortkwamen uit de kringen der kleine ambachtslieden (Baumann, 
1915; Prakken, 1977). De doctores medicinae studeerden, nadat zij de Latijnse school doorlopen hadden, aan één der universiteiten: Leuven (opgericht in 1426), Leiden (1575) of Utrecht (1636) of aan één der provinciale inrichtingen: Franeker (1585), Groningen (1614), Harderwijk (1648), of aan één der "lllustre scholen": 's Hertogenbosch (1629), Breda (1646), Middelburg (1656), Amsterdam (1659). Het onderwijs was sterk theoretisch gericht met het accent op natuurwetenschappelijke vakken. De opleiding aan de universiteit werd meestal vervolgd met een studiereis naar een beroemde buitenlandse academie, meestal een Franse of Italiaanse, om aldaar de doctorsgraad te behalen. In latere tijden promoveerden de artsen doorgaans aan een der Nederlandse universiteiten of hoge scholen. Bij de promotie tot doctor in de geneeskunde legden de aspirant-artsen de eed van Hippocrates af. De verplichtingen van de doctoren vloeiden voort uit de eed en waren anderdeels bepaald door bestaande verordeningen (Lindeboom, 1977). De heel- en vroedmeesters stonden onder het toezicht van de gilden. De vroedmeesters behoorden tot het chirurgijnsgilde, maar vormden hierbinnen een eigen groep (Lieburg, 1978, 1988). In het chirurgiinsgilde waren de beoefenaars van het medische beroep verenigd. Een van de taken van een dergelijk gezelschap was toezicht te houden op de opleiding en examinering van toekomstige collegae. De opleiding vond plaats volgens hel meester-gezel principe. De aanstaande chirurgijn leerde het vak door bij een ervaren meester-chirurgijn praktijk te doen in alles wat in die tijden tot de uitwendige geneeskunst gerekend werd, zoals behandeling van wonden, beenbreuken, gezwellen en dergelijke. De meester stelde een contract op met de leerjongen dat hem verplichtte de leerjongen een zekere tijd "in sijn huys te logeren ende te onderhouden" en hem gedurende die tijd "te sullen leren getrouwelijck het hantwerk van chirurgie" (geciteerd bij Lieburg, 1978, p. 17). De leeriongen functioneerde veelal als een goedkope arbeidskracht. De gilden registreerden het moment dat een leerjongen was aangenomen, vooral om te kunnen nagaan of aan de vereiste minimum leerperiode van twee jaar zou worden voldaan. De leerlingen haalden hun theoretische kennis uit boeken, door het volgen van lessen en door het bijwonen van operaties op kadavers. Het chirurgijnsgilde besefte al vroeg de noodzaak van een gedegen theoretische en praktische scholing. In steden organiseerden zii daarom regelmatig onderwijsbijeenkomsten om leerlingen de vereiste theoretische kennis bij te brengen. Dit leidde tot het optreden van repetitoren in de chirurgie.

In 1593 voerde het chirurgijnsgilde reeds examens in. Als examinatoren functioneerden meesters die hun sporen in de chirurgie verdiend hadden. In de loop van de tijd werden de examens 
steeds zwaarder en uitgebreider. Aanvankelijk richtte het examen zich vitsluitend op de toetsing van theoretische kennis maar sedert $1626 \mathrm{kwam}$ ook de beheersing van praktische vaardigheden aan de orde. De examinandus ging daarvoor met de proefmeester en de stadschirurgijn naar het gasthuis "om aldaer geexamineert en ondervraecht te werden in de practycque van chirurgia, op ieder werck sodanich hem alsdan vertoont sal werden" Igeciteerd bij Lieburg, 1978, p. 16). De invoering van examens had zijn weerslag op het onderwijs en eiste van meesterchirurgijns een zeer serieuze bijdrage inzake de vorming van de leerjongen (Lieburg, 1978).

In de Franse tijd (1795-1813) werd het gildewezen afgeschaft en daarmee ook de opleiding en examinering in gildeverband (Drogendijk, 1977). In 1798 werden alle gilden bij Algemene Wet officieel ontbonden verklaard. Voor de Franse tijd bestond er geen toezicht op geneeskundigen of geneeskundige aangelegenheden. De Fransen brachten door de instelling van zowel gewestelijke als plaatselijke toezichtcommissies een andere en tevens betere vorm van controle op de geneeskunde in Nederland. De Fransen stelden "Departementale Commissien voor Geneeskundig Onderzoek en Toevoorzigt" in, die voortaan alle medische examens op niet-academisch niveau zouden afnemen. Zij kregen het recht heelen vroedmeesters, apothekers en vroedmeesters in stad en platteland te examineren en die kwaliteit te bevorderen. Daarnaast hielden zij algemeen toezicht op de vitoefening van de geneeskunst en troffen maatregelen bij uitbrekende epidemische ziekten. De "Plaatselijke Commissien voor Geneeskundig Toevoorzigr" hielden roe zicht op de uitoefening van de geneeskunst in de grote steden, waarin vier of meer doctores medicinae waren gevestigd (Drogendijk, 1977). Deze nieuwe organisatie werd op 20 maart 1804 vastgelegd in een Geneeskundige Staatsregeling. Plaatselijke verorderingen regeiden verdere bevoegdheden. Wat de omvang van de praktijk betreft, mochten de doctores medicinae volgens artikel 2 van het "Reglement der Geneeskunde" (1808) alleen de inwendige geneeskunde beoefenen en "in geval van consultatie of buitengewonen omstandigheden, zijnen bemoeijingen ook tot de heel- en verloskunde uitstrekken" (geciteerd bij Drogendijk, 1977, p. 1967). Voor deze laatste twee kundes van de geneeskunde, toen nog onderscheiden, behoefden zij zich niet apart te bekwamen of een examen af te leggen. De opleiding van respectieveliik doctores medicinae en chirurgijns bleef in de Franse tijd echler onveranderd. De doctor, de geleerde, genoot een academische opleiding, de chirurgiin, de handwerksman, een praktische (Drogendijk 1977; Lieburg, 1978; Lindeboom, 19711.

Na een intermezzo van toezicht rijdens de Franse rijd poogde 
de regering in ons land de oude structuur te herstellen. In 1814 leidde dit tot de instelling van een "commissie tot herziening der geneeskundige wetten en verordeningen, zoowel in de noordelijke als de zuidelijke provinciën des rijks in vigeur". Mede door conflicten binnen de commissie onderging het toezicht na 1822 enige wijzigingen, welke overigens geen enkel gevolg voor de praktijk hadden. Door de afwezigheid van structuur en personeel was het toezicht op de opleiding en gezondheidszorg slecht en waren de kwaliteitsverschillen tussen artsen groot (Goudsmit, 1978). Het geneeskundig onderwijs viel officieel geheel onder verantwoordelijkheid van de universiteiten van Leiden, Utrecht en Groningen. Volgens het toenmalige Besluit tol regeling van het hoger onderwijs (1815) zouden de medische faculteiten aldaar bevoegd zijn tot het verlenen van drie graden die de medische praktijk toen kende: die van doctor medicinae, doctor chirurgiae en doctor artis obstetricae. Daarnaast bestond de mogelijkheid om een opleiding te volgen aan de "Klinische Scholen". Deze waren in 1823 opgericht om in de behoefte aan geneeskundige hulp, met name op het platteland, te voldoen. De Klinische Scholen hadden niet de status van een wetenschappelijk opleidingsinstituut. Dit blijkt ook uit de toelatingseisen die aan de aspirant-kwekeling werden gesteld namelijk het bezit van "een gezond en voor de vitoefening van het beroep geschikt ligchaamsgestel, een bewijs van een onbesproken gedrag, het kunnen lezen en schrijven en ingeval men de chirurgie tot hoofdvak koos, het vermogen om de gedachten geregeld in schrift (te) kunnen uitdrukken" (geciteerd bij Lieburg, 1978, p.62). ledere stad mocht een Klinische School oprichten mits "zonder bezwaar van 's Lands kas" (Arntzenius geciteerd bii Goudsmit, 1978, p. 21). Het gevolg was dat de kwaliteit van Klinische Scholen enorm viteenliep, al naar gelang een stad bereid was veel of weinig geld aan deze instelling te besteden. Het resultaat was dat ons land halverwege de 19 de eeuw diverse soorten artsen kende, met verschillende bevoegdheden op verschillende gebieden (Goudsmit, 1978). De striid binnen het medisch beroep tussen die van de academisch gevormde doctores medicinae aan de ene kant en de niet-universitair geschoolde heel- en vroedmeesters aan de andere kant bleef dan ook voortbestaan. De vervaging van de grenzen tussen de praktijkvoering van beide categorieën bereikte in de tweede helft van de 19 de eeuw een climax. Een kleine groep van meest jonge, progressieve denkende geneesheren zocht de oplossing van deze conflicten niet in een regeling van de intercollegiale verhoudingen tussen beide hoofdcategorieen, maar in een uniformering van de medische stand (Lieburg, 1988). De eenheid van hel geneeskundig beroep, die in de meeste omringende landen reeds een feit was, en liefst ook de een- 
heid van opleiding diende volgens hen ook in Nederland gerealiseerd te worden. Als eerste resultaat van streven richtten zij in 1849 de Nederlandsche Maatschappij tol Bevordering der Geneeskunst (NMG) op. Het doel van de NMG was "de waardigheid van den geneeskundigen stand in de oogen des Nederlandschen publieks te doen rijzen en de belangen en regten van dien stand te doen rijzen en de belangen en regten van dien stand krachtdadig te handhaven" (geciteerd bij Festen, 1974, p.49). De eindoverwinning volgde tenslotte in 1865, loen regeringsleider en minister van Binnenlandse Zaken, Thorbecke, er na een serie mislukte pogingen eindelijk in slaagde de wetten betreffende geneeskundige staatsregeling door het parlement aanvaard te krijgen. De eenheid van het beroep, tot uitdrukking gebracht in de nieuwe titel "arts" was daarmee wettelijk tot stand gebracht. Voor de "tweede geneeskundige stand", de heelen vroedmeesters, betekende de vitkomst van de stemming door de Tweede en Eerste Kamer het doodvonnis (Lieburg, 1988). Er werden twee nieuwe staatsexamens ingevoerd, een natuurkundig en een geneeskundig - die werden afgenomen door commissies die onathankelijk van de medische faculteiten zich zouden verzekeren van de bekwaamheid der aanstaande beoefenaren der geneeskunst. Het natuurkundig examen was geheel theoretisch. Het geneeskundig examen daarentegen was theoretisch en praktisch. Toelating tot het geneeskundig examen vereiste dat de kandidaat minstens twee jaar betrokken was geweest bij de behandeling van zieken en het bewijs dat hij in tegenwoordigheid van een verloskundige twaalf bevallingen had verricht. De titel van genees-, heel- en verloskunde werd uitsluitend toegekend aan diegenen, die het natuurkundig en geneeskundig examen hadden afgelegd. Aan deze titel was "de bevoegdheid tot vitoefening der praktijk in haren geheelen omvang" verbonden (Staatsblad, 1865, nr. 59). De algemene geldigheid van het artsdiploma werd daarmee een feit. Ook de eenheid van opleiding beslaande uit een theoretisch en praktisch gedeelte, was daarmee binnen het vizier gebracht. De Klinische Scholen werden in 1865 . 1866 gesloten. Als gevolg hiervan moesten alle toekomstige artsen het universitair onderwijs volgen. Vanwege de toename van het aantal studenten dientengevolge ontstonden er op de universiteiten personeels- en materiële problemen wat de kwaliteit van het onderwijs niet ten goede kwam. Voorts bleek de invoering van het staatsexamen andere effecten te hebben dan de regering ermee beoogde. Vaak werd geheel verouderde kennis geëxamineerd en het onderwijs werd op deze eisen afgestemd, "zoodat zij geen vraag missen" (geciteerd bij Goudsmit, 1978, p.30). De wet van 1865 resulteerde dan ook niet in betere opgeleide artsen (Goudsmit, 1978; Lieburg, 1978). 
Na 1865 is er op wetenschappelijk gebied een snelle ontwikkeling te constateren op het terrein van de natuurkunde en scheikunde. Dit is van invloed op de inhoud van het medisch onderwijs. Hel theorefische deel van het curriculum breidde zich steeds meer uit en de afstand tot de praktiik werd steeds groter. Stellingen werden verkondigd als: "'Het physisch-chemisch onderzoek dient aan de anamnese vooraf te gaan', alsof de taak van den geneeskundige en van den veearts dezelfde waren" (geciteerd bij Goudsmit, 1978, p.40). Een eenzijdig accent op de theorie blijkt ook uit het feit dat de twee staatsexamens inmiddels geheel theoretisch waren en in 1878 leidde tot de invoering van een derde examen - het artsexamen. De staatscommissie die verantwoordelijk was voor de afname van examens functioneerde geïsoleerd van de faculteit, wat niet effectief bleek te zijn. Men besloot de verantwoordelijkheid voor de examinering over te dragen aan de faculteiten. Het gevolg was dat de eigen docenten van de faculteiten wederom de examens gingen afnemen. Namens haar beroepsgroep sprak de Nederlandse Maatschappij tot bevordering der Geneeskunst haar bezorgdheid vit over de kwaliteit van de afgestudeerden. Zij stelt: "De jonge arts komt, volgens de vrij wel algemene mening der deskundigen, nief goed genoeg beslagen ten ijs. Ofschoon hij vrij wat heeft geleerd, staat hij nog re onbeholpen voor de praktijk. Men wenscht hem beter geoefend te zien, vooral ook in de behandeling van zieken" (Nederlandse Maatschappii tol Bevordering der Geneeskunst [NMG], 1909 , p. 358). Het NMG pleitte voor maatregelen om de kloof tussen theorie en praktijk re verkleinen bijvoorbeeld door - naar analogie van Duitsland- de invoering van een "Praktisch Jahr", waarbij de student na het artsdiploma buiten de universiteit een jaar als assistent werkt in een ziekenhuis.

De 20ste eeuw werd gekenmerkt door de opkomst van verschillende specialismen, het resultaat van arbeidsdeling in diverse disciplines. Het aantal specialistische vakken dat de student moest volgen, nam door deze ontwikkeling sterk toe, wat resulteerde in een langere studieduur. De opleiding bedroeg inmiddels zeven tot acht jaar. Het inzicht ontstond dat bii ziekten ook psychische en maatschappelijk factoren een rol spelen. Het zijn met name de praktiserende geneeskundigen die ervoor pleitten om het accent van het theoretisch deel van de opleiding in die richting te verschuiven. Dit leidde tol de invoering van de vakken gezondheidsleer en sociale geneeskunde. Er werd echter geen geld beschikbaar gesteld voor leersłoelen, waardoor de fysisch en biologisch georiënteerde vakken de overhand bieven houden in het curriculum. Het resultaat was een opleiding bestaande vil twee gescheiden fasen: de pré-klinische en de klinische fase. De pré-klinische docenten, in afnemende mate 
zelf arts, doceerden de basisvakken. Dat onderwijs volgde de ontwikkelingen op de afzonderlijke vakgebieden, onafhankelijk van de vraag of die kennis wel of niet van nut was voor de latere beroepspraktijk. De specialisten doceerden het klinische deel van de opleiding. Zij zagen de basale universitaire opleiding vooral als voorbereiding op de specialisatieperiode en op die van hun eigen vak. Het onderwijs aan het "ziekbed" kwam steeds meer in het gedrang.

Kennis van de sociale geneeskunde vonden de meeste docenten van minder belang. Voor de beroepsuitoefening van hun vak was alleen dat vak zelf van alles overheersend belang. Normen, richtliinen of doelstellingen kenden de opleiding niet of nauwelijks. Het resultaat was een opleiding die ver stond van de medische en sociale problemen van alledag. Illustratief hiervoor is de uitspraak: "De student leert wel ziekten, doch geen zieken te behandelen" (Romein gecireerd bij Goudsmit, 1978, p.70).

In november 1920 werd het ontwerp voor een nieuw Academisch Statuut aan de minister aangeboden. Op 24 en 25 mei 1921 nam de Tweede Kamer het wetsontwerp aan. Het Academisch Statuut betekende voor de medische opleiding evenals voor de meeste studies een bestendiging van de bestaande situatie. Voor de medische faculteit volstond het Academisch Statuut met een opsomming van te examineren vakken in plaats van doelstellingen voor de opleiding. De faculieiten waren vrij om binnen de grenzen van het Academisch Statuut te onderwijzen wat hen goed dunkte. Het staatsexamen werd officieel afgeschaft (Goudsmit, 1978).

$\mathrm{Na}$ de Tweede Wereldoorlog nam het aantal studenten in het hoger onderwijs toe. Universitaire voorzieningen werden daarenlegen niet uitgebreid, wat zorgde voor de nodige problemen. De discussie die al voor de Tweede Wereldoorlog over de relatie tussen de maatschappij en het wetenschappelijk onderwijs werd gevoerd, laaide weer fel op en was in 1946 aanleiding tot de instelling van de commissie-Reinink, officieel "de Staatscommissie tot reorganisatie van het hoger onderwijs". Een sectie van deze commissie hield zich expliciet bezig met het medisch onderwijs. De taak van deze sectie was een antwoord te geven op de vraag in hoeverre reorganisatie en vernieuwing aangebracht behoorden te worden in de geneeskundige opleiding, examens en promoties opdat die in overeenstemming zouden worden gebracht mel de eisen van wetenschap en maatschappij (Reinink, 1949). Het rapport van de commissie-Reinink noemde een grool aantal organisatorische veranderingen die zouden moeten worden doorgevoerd: 
- $\quad$ uitbreiding van het aantal medische faculteiten;

- verdubbeling van het aantal hoogleraren;

- vitbreiding van het aantal affiliatie-ziekenhuizen om meer studenten buiten het academisch ziekenhuis te kunnen opleiden; vergroling van de mogelijkheden voor studenten om welenschappelijk werk te doen door uitbreiding van de laboratoria; opstelling van doelmatige onderwijsprogramma's voor studenten en

bespreking van de problemen van het geneeskundig onderwijs door de gezamenlijke medische faculteiten.

Wat de inhoud van de studie betreft, kwam het voorstel om de sociale geneeskunde in de studie meer op de voorgrond te plaatsen en hiervoor binnen elke universiteit een hoogleraar te benoemen. Verder stelde de commissie nog een tweetal hervormingen voor ten aanzien van het doctoraal examen en de specialistenopleiding. De sectie wenste een apart doctoraal examen te scheppen dat niet verplicht was voor de opleiding tot algemeen arts, maar alleen voor degenen die wilden promoveren of een specialistenopleiding wilden volgen. Bovendien werd voorgesteld de opleiding van specialist . die onder verantwoordelijkheid viel van de betreffende beroepsgroepen - bij de universiteit onder te brengen, terwij studenten al na het kandidaarsexamen het pad naar het artsexamen zouden kunnen verlaten om via een apart doctoraalexamen specialist te worden. Op die manier zou een vroege specialisatie ontstaan. Al bij hel verschijnen van het rapport van de commissie-Reinink in 1949 bleek uit de discussies onder medici, dat weinig steun voor deze voorstellen bestond. De Koninklijke Nederlandse Maatschappij tot bevordering van de Geneeskunst (KNMG) verzette zich tegen de plannen to differentiatie van de medische studie, omdat daarvoor opnieuw verschil in opleidingsniveaus en daarmee - evenals in 1865 - verschil in stand gecreëerd werd. De eenheid van opleiding tot arts moest behouden blijven (Koninklijke Nederlandse Maatschapij tot bevordering der Geneeskunst [KNMG], 1951). Ten aanzien van de inhoudelijke eisen die de sectie stelde aan de verbetering van het medisch onderwijs, was het de mening van de KNMG, dat het niet de taak was van de overheid om zich te bemoeien met de inhoud van iets waar ze geen verstand van had, ondanks het feit dat men het met veel eisen eens was. Dit verzet was te herleiden tot het beleid van de KNMG dat gericht was op het behoud van haar positie en aanzien in de praktijk van de gezondheidszorg. Illustratief hiervoor is de reactie van Professor van Loghem (1949) op het rapport van de staatscommissie: "Het is de taak van de faculteit eenheid en evenwicht te behouden bij de geleidelijke wijzigingen die 
zich openbaren. Zij heeft acht te geven op hen die aan haar voordeur kloppen en het oog te houden op anderen die langs de achterdeur trachten haar binnen te dringen. Door het voorstel der Sectie voor Geneeskunde van de Staatscommissie tot Reorganisatie van het Hoger Onderwijs worden deze eenheid en evenwicht bedreigd. Maar de strekking van het voorstel gaat verder en dieper. Laten wij erkennen, dat het tot een maatschappelijk kwaad leidt: de ondermijning van het aanzien van de geneeskundige stand" (van Loghem, 1949). De felle kritieken hadden tot gevolg dat er met de aanbevelingen van het rapport-Reinink in de praktijk weinig werd gedaan.

In de loop van de zestiger jaren ontstond opnieuw beweging, gericht op de verbetering van de opleiding. Zo verscheen in 1965 in Utrecht een "Nota over de artsopleiding" (Utrecht, 1965), waarin gepleit werd voor meer wetenschappelijke vorming, meer klinische contacten en een specialisatie tot huisarts. In 1966 startte de Rotterdamse medische faculteit met een aantal vernieuwingen zoals verhoging van de zelfwerkzaamheid van studenten door reductie van het aantal hoorcolleges en invoering van keuze-vakken. Daarnaast legden men het accent op wetenschappelijke vorming en op vroeglijdige introductie van het klinisch onderwijs, ondermeer door de invoering van junior-co-assistentschappen (Moll, 1983; van der Werff ten Bosch, 1973). Ook aan de andere faculteiten waren er allerlei aanzetten tot vernieuwingen. Het Academische Statuut van 1921 hield echter - door de opsomming van vakken - grootschalige veranderingen tegen. In de faculteiten groeide de overtuiging dat een flexibele en ruimere formulering van het Statuut noodzakelijk was om de opleiding beter te kunnen aanpassen aan de eisen van de tijd. Er diende een nieuw Academisch Statuut te komen, waarin een lijst met globale doelstellingen moest komen in plaats van een concrete vakgerichre opsomming. Het voordeel hiervan zou zijn dat niet voor elke curriculumwijziging Staluutwijzingen behoefden te worden aangebracht.

In 1966 verzocht de minister van Onderwijs en Wetenschappen het Interfacultair Overleg Geneeskunde (IOG), dat al ver voor de jaren ' 60 bestond, maar nauwelijks functioneerde, een advies over de opbouw en de lengte van de medische studie uit te brengen. In de opdracht lag besloten, dat ook aandacht aan de plaats en de duur van de huisartsopleiding geschonken moest worden. Het artsdiploma gaf de wettelijke en feitelijke bevoegdheid tot zelfstandig vitoefenen van de geneeskunde in haar volle omvang; en daarmee dus ook van de huisartsgeneeskunde, waarvoor toen nog geen afzonderlijk specialisme bestond. Al vanaf het begin van de jaren '60 pleitten huisartsen in toenemende mate voor de erkenning van het eigen karakter van dat vak. Dit mede op basis van de kritiek op de bestaande medische opleiding, die volgens de huisartsen niet 
voldeed aan de eisen die door de eerstelijnsgeneeskunde werden gesteld. Aan dit laatste punt werd prioriteit gegeven in de vorm van een "Raamplan-huisartsenopleiding" (Interfacultaire Overleg Geneeskunde $[I O G], 1967)$. Het IOG stelde voor de duur van de artsopleiding terug te brengen tol zes jaar welke niet automatisch het recht tot de uitoefening der huisartsgeneeskunde zou verlenen. Het eindniveau van de nieuwe opleiding diende het ingangsgniveau te zijn voor alle medische specialisaties inclusief de huisartsgeneeskunde. Dit schema, waardoor de huisartsgeneeskunde als "specialisme" erkend zou worden, werd door de overheid toentertijd afgewezen op juridische gronden. De overheid koos voor een in zes jaar op te leiden "assistent-arts", die eerst na een aanvullende scholing van een jaar het arts-examen zou kunnen afleggen. Alleen aan het behalen van het artsexamen zou de volledige bevoegdheid verbonden worden. Deze opzet gold voor alle artsen, inclusief huisartsen (Metz, 1984). Voorts stelde het IOG voor om de vakgerichte opsomming in het Academisch Statuut te laten vervallen ten gunste van een kwalitatieve omschrijving van het gebied en van het niveau waarop de medische opleiding zich beweegt. Op 8 oktober 1968 werd deze ruime formulering voor het Academisch Statuut bij Koninklijk Besluit goedgekeurd. De examens van de artsenstudie worden dan niet langer aangeduid als een opsomming van vakken, maar met een globale omschrijving. Tussen 1968 en 1973 is het Academisch Statuut in een aantal opzichten verder aangepast of aangevuld. Het gaat hierbii om afschaffing van het assistent-artsexamen (Academisch Staluut, artikel 27, 1973). Her doctoraalexamen wordt gevolgd door het artsexamen. De nu tweejarige post-doctorale opleiding blijft de voorbereiding beogen van de volle verantwoordelijkheid die op de arts rust, en op hel zich bekwamen tot zelfstandige vitoefening van de geneeskunst door voortgezette vorming in een aantal facetten of onderdelen van de geneeskunde. Formeel omvat het artsexamen echter slechts her "onderzoek van de bekwaamheid tot het vitoefenen van de geneeskunst" (Koninklijk Besluit 8 mei 1973, Stbld. 206).

Vanaf 1968 pogen de universiteiten een zesjarige basisartsopleiding en een huisarlspecialisatie tot werkelijkheid re maken. De toenemende studentenaantallen en de kosten van de medische opleiding waren voor de overheid aanleiding enige richling te geven aan de ontwikkelingen. Professor dr. A. Querido werd gevraagd de ministeries van Onderwijs en Wetenschappen, en van Sociale Zaken en Volksgezondheid te adviseren omtrent organisatie en planning van het medisch onderwijs. Dit resulteerde in Memorandum I (Querido, 1970). De belangrijkste conclusies van Memorandum I waren dat de planning in ons land een achterstand vertoonde vergeleken 
met die in het buitenland. Gesteld werd dat de kwaliteit van de opleiding wel eens ernstig te lijden zou kunnen krijgen bij het uitblijven van een meer planmatige aanpak en bij het ontbreken van onderzoek naar de financiële, personele en technische consequenfies van het gevoerde beleid. Als vervolg hierop werd in 1971 de Werkgroep Planning Medisch Wetenschappelijk Onderwijs ingesteld bestaande uit de hoogleraren A. Querido, P.J. Thung en H.A.W.M. Tiddens. Het werk van deze groep resulteerde in Memorandum II (Werkgroep planning medisch welenschappelijk onderwijs, 1971), dat is opgesteld in samenspraak met het Interfacultair Overleg Geneeskunde. Memorandum II beschreef de knelpunten die de faculteiten verwachten en pleitte ervoor de vage formuleringen van de inhoud van het onderwijs zoals verwoord in het Academisch Statuut nader te preciseren. Tiddens stelde in Memorandum II (1971): Zolang men nog niet in staal is tot het nauwkeurig aangeven van doelstellingen en wenselijke leersituaties en we ons dus met globale benaderingen moeten behelpen, lopen we het risico van de invoering van schijnoplossingen". De onderwijscommissie van het IOG stelde dat een dergelijke opleiding van toekomstige artsen en specialisten met duidelijke doelstellingen, een hoeksteen is voor een effectief en efficiënt beleid van de gezondheidszorg. De onderwijscommissie van het $1 O G$ ontwierp in de loop van 1973 een rapport over de globale doelstellingen van de artsopleiding, onder de titel "Raamplan 1974". In juni 1974 werd dit raamplan door alle faculteiten onderschreven (Interfacultair Overleg'Geneeskunde [IOG], 1974). Het raamplan bevat een vijftal doelstellingen, die als richtliinen bedoeld zijn voor de faculteiten en de colleges voor beroepsopleidingen.

Eind 1975 wordt de Wet Herstructurering Wetenschappelijk Onderwijs (1975) aangenomen, waarbij cursus en inschrijvingsduur werden beperkt. De meeste medische opleidingen duurden nog zeven tot zeveneneenhalf jaar en moesten beperkt worden tot zes jaar. Herprogrammering was onontkoombaar. Tevens waren zowel staf en studenten het erover eens dat de gelegenheid moest worden aangegrepen om de studie af te stemmen op de praktijk van de gezondheidszorg. We zullen in paragraaf 2.3 nader ingaan op aanzetten tot vernieuwingen, die daarvan het gevolg waren. Eerst zullen echter enkele belangriike internationale ontwikkelingen beschreven worden, die mede van invioed zijn geweest op de Nederlandse situarie. 


\subsection{Internationale ontwikkelingen}

In de zeventiger jaren zijn er ook internationaal gelviden hoorbaar dat het medisch onderwijs onvoldoende is afgestemd op de eisen van de roekomstige samenleving. Er zijn diverse aanzetten om het onderwijs op een andere manier gestalte te geven. Een belangrijk initiatief hiertoe is in 1979, mede door het toedoen van de World Health Organization (WHO), de oprichting van het "Network of Community-Oriented Educational Institutions for the Health Sciences". Bij het Network zijn medische faculteiten uit de hele wereld aangesloten die gezamenlijk zorg willen dragen voor onderwijs dat aansluit bij de behoeften van de samenleving. Halverwege de twinligste eeuw werden in de relatie tussen medisch onderwijs en gezondheidszorg twee verschillende, hoewel met elkaar gerelateerde problemen, gesignaleerd. Ten eerste werd vastgesteld dat bevolkingsgroepen niet in dezelfde mate een beroep kunnen doen op de gezondheidszorg. Mede doordat in bepaalde delen van de wereld een tekort aan artsen is. Dit komt enerzijds doordat artsen zich bij voorkeur vestigen in gebieden waar voldoende technische faciliteiten voor de beroepsuitoefening aanwezig zijn en waar een zekere mate van welvaart heerst. Anderzijds ontbreekt het in bepaalde landen en streken aan opleidingsmogelijkheden voor artsen, waardoor elders een opleiding gevolgd moet worden en afgestudeerden veelal niet terugkeren naar het gebied van herkomst. Deze problematiek manifesteert zich het sterkst in de ontwikkelingslanden. Een tweede probleem is dat de praktische opleiding van medische studenten hoofdzakelijk plaatsvindt in ziekenhuizen. De faciliteiten die in opleidingsziekenhuizen aanwezig zijn, ontbreken daar waar artsen na hun opleiding te werk gesteld worden. Daarnaast wijkt de populatie patiënten in ziekenhuizen af van die waar een arts normaliter mee geconfronteerd wordt. Om wat tegen deze problemen te ondernemen besloot een twintiglal faculteiten over de hele wereld zich te verenigen in een Network. Het doel was om zogeheten "communityoriented medical curricula" te propageren. Dergelijke curricula kenmerken zich doordat het onderwijs is opgezet aan de hand van belangrijke actuele gezondheidsproblemen van de bevolking binnen een bepaalde samenleving. De problemen en hun oplossingen zijn afhankelijk van de populatie, omgeving en tijd waarin mensen leven. Problemen waarmee de gezondheidszorg in de ontwikkelingslanden kampt zullen anders zijn dan die van de geindustrialiseerde landen. Praktisch onderwijs zou moeten plaatsvinden in diverse instellingen die vanuit verschillende invalshoeken betrokken zijn bij de zorgverlening. Niet alleen ziekenhuizen, maar ook eerstelijnsvoorzieningen zouden voor onderwijs ingezet moeten wor- 
den. Gezondheidsvoorlichting en preventie zouden in het curriculum aan de orde moeten komen naast het aanleren van klinische vaardigheden. De leden van het Network komen jaarlijks bijeen om ideeën uit te wisselen en elkaar te ondersteunen bij onderwijsvernieuwing. Het aantal leden is in de loop van de jaren toegenomen van 20 instituten in 1979 to 167 instituten in 1990 (Richards et al., 1987; Schmidt et al., 1991).

In de Verenigde Staten is het Flexner-rapport (1910) lange tijd toonaangevend geweest voor de inrichting van het medisch onderwijs. Hel rapport is indertijd opgesteld op verzoek van de American Medical Association (AMA) door Abraham Flexner, lid van de "Carnergie Foundation for the Advancement of Teaching". De aanleiding voor dit rapport was de kritiek op de wetenschappelijke kwaliteit van het medisch onderwijs in de Verenigde Staten. De kerngedachte van het rapport is dat studenten gedurende hun universitaire opleiding een gedegen wetenschappelijke opleiding én praktische klinische opleiding dienen te kriigen. Vanaf het begin van de twintigste eeuw fungeerde hel Flexner-rapport als leidraad om het onderwijs in de Verenigde Staten te reorganiseren. De wetenschappelijke kwaliteit van de opleiding kreeg hierdoor een sterk accent. De praktiik van de gezondheidszorg werd echter vit het oog verloren (Starr, 1982). Omstreeks de zeventiger jaren zijn er in de Verenigde Staten al meer geluiden te horen dat het onderwijs onvoldoende zou aansluiten bij de veranderde samenleving. Ideeën over de richting van mogelijke veranderingen zijn verwoord in het "Report of the Panel of the General Professional Education of the Physician and College Preparation for Medicine" ook wel aangeduid als het "GPEP-rapport" (Association of American Medical Colleges, 1984). Het rapport is opgesteld door verlegenwoordigers van alle medische beroepsverenigingen in de Verenigde Staten. Op basis van een analyse van de opleiding en de eisen die de samenleving stelt aan artsen, worden een vijftal conclusies getrokken.

De eerste conclusie heeft betrekking op de doelen van de medische opleiding. Naast aandacht voor kennisverwerving moet volgens het rapport eveneens tijd besteed worden aan het verwerven van vaardigheden en attitudevorming. Het onderwijsprogramma dient in te spelen op de behoeften en wensen van de veranderde samenleving. Naast medisch-lechnische vaardigheden dient ruimte te zijn voor preventie en voorlichting van ziektes. De samenstellers van het GPEP-rapport pleitten voor duidelijk omschreven doelstellingen waaraan de aspirant-arts dient te voldoen. De vaststelling van de doelstellingen moet gebeuren in overleg tussen artsen die participeren in de pré-klinische en de klinische fase van de opleiding.

De tweede conclusie betreft de opzet van een brede algemeen ge- 
oriënteerde opleiding. Een vroegtijdige specialisatie is niet gewenst. Naast kennis van de medische en natuurwetenschappen is scholing in sociale wetenschappen noodzakelijk. De toelating tot medische opleidingen dient niet uitsluitend gebaseerd te zijn op academische kwalificaties, maar ook op het vermogen om kritisch en zelfstandig te kunnen werken.

De derde conclusie heeft betrekking op het verwerven van kennis en vaardigheden. In de latere beroepsuitoefening speelt het analyseren en begrijpen van problemen een belangrijke rol. Daarom dient tijdens de opleiding aandacht te zijn voor het verwerven van vaardigheden in het zelfstandig oplossen van problemen. Vermindering van het aantal colleges is wenselijk ten gunste van onderwijsactiviteiten waarbij de zelfwerkzaamheid van studenten centraal staat, bijvoorbeeld in werkgroepen en practica. Door de verroosterde tijd lerug te brengen, komt er meer ruimte voor zelfstudie. Het evaluatiesysteem moet dusdanig zijn dat toetsing van het probleemoplossend vermogen van studenten plaatsvindt. Tenslotte moet het gebruik van computers binnen het onderwijs gestimuleerd worden.

De vierde conclusie heeft betrekking op de inrichting van het klinisch onderwijs. Structurering van het klinisch onderwijs is een voorwaarde. Een omschrijving van kennis, vaardigheden en attitudes in de vorm van doelstellingen is noodzakelijk, waardoor ook de beoordeling van prestaties betrouwbaar kan gebeuren. Binnen het klinisch onderwijs is zowel het verblijf van de student op de polikliniek als op de ziekenhuisafdeling belangrijk. Artsen moeten tijd krijgen voor de voorbereiding en vitvoering van het onderwijs.

De viffde conclusie heeft betrekking op de samenstelling van een interdisciplinair en interdepartementaal team van faculteitsmedewerkers, dat de verantwoording draagt voor een coherent en inhoudelijk goed onderwijsprogramma. Een team moet eveneens zorgdragen voor de selectie van instructie- en evaluatiemethoden. Voorts moet een dergelijke groep zich bezig houden met de planning, de implementatie en de supervisie van onderwijsactiviteiten. Faculteitsmedewerkers moeten gelegenheid krijgen zich begeleidings- en didaclische vaardigheden eigen te maken.

De ideeën van het GPEP-rapport zijn van grote invloed geweest op veranderingen van hel medisch onderwijs binnen è buiten de Verenigde Staten. Als vervolg op het GPEP-rapport vinden er talrijke conferenties plaats, die de ideeën van het GPEP-rapport proberen te vertalen naar de praktijk van het medisch onderwijs. Belangrijk zijn in dit kader de "Edinburgh Declaration", opgesteld door de World Federation for Medical Education en de World Health Organization (1988). Het document stelt, dat het medisch onderwijs, ondanks de grote voorvitgang in de biomedische weten- 
schappen, er niet in is geslaagd artsen op te leiden die de gezondheid van alle mensen kunnen bevorderen. In het rapport worden een aantal aanbevelingen gedaan die in grote lijnen overeenstemmen met die van het GPEP-rapport (World Federation for Medical Education, 1989). Om de aanbevelingen die vermeld staan in de Edinburgh Declaration te effectueren voor de Europese regio vond in 1988 te Lissabon een "Ministerial Consultation" plaats, waaraan werd deelgenomen door de Nederlandse Vereniging voor Medisch Onderwijs en ambtelijke vertegenwoordigers van het ministerie voor Welzijn, Volksgezondheid en Cultuur en het ministerie van Onderwijs en Wetenschappen. Deze bijeenkomst heeft geresulteerd in "The Lissabon Initiative". De inhoud van dit document richt zich op maatregelen om het medisch onderwijs te reorganiseren tegen de achtergrond van de behoefte van de gezondheidszorg (Lissabon Initialive in Scherpbier, 1988).

\subsection{Medisch onderwijs in discussie}

De hierboven beschreven suggesties voor verandering worden gereflecleerd in de discussies die in dezelfde periode in Nederland plaatsvonden. Met name het interfacultaire overleg van de Nederlandse faculteiten heeft veel aandacht besteed aan de opleiding tot arts. In hun nota's zijn de belangrijkste kritiekpunten terug te vinden (IOG, 1967; Moll \& Gerritsma, 1983). Het hiernavolgende bevat een samenvatting van de voornaamste commentaren op het medisch onderwijs. Vervolgens komen de belangrijkste vernieuwingen aan de orde die zich de laatste jaren in Nederland hebben voorgedaan.

In het onderwijs fungeert de docent als kennisoverdrager en de student als ontvanger. De student kriigt hierdoor de rol van een "passief en noodgedwongen geïnteresseerd consument". Zowel studenten als docenten pleiten voor onderwijs waarbij studenten actiever betrokken worden zodat de "student inzicht krijgt in de wetenschappelijke denkmethoden, deze methoden leert beheersen en 'de weg naar het feit' opnieuw aflegt met behulp van hen, die de weg beheersen en tevens om dit te doen in werkgroepen" "Juffermans geciteerd bij Goudsmit, 1978, p. 155). Daarom moet de opzet van het onderwijs meer studentgericht zijn in plaats van docentgericht.

Het onderwijs gaat uit van de diverse disciplines. Er is onvoldoende integratie van de basisvakken en de klinische specialismen. Door de vakgerichte benadering bereidt het onderwijs studenten onvoldoende voor op de praktijk. Door uit te gaan van problemen, afkomstig uit de gezondheidszorg, zou het onderwijs meer aansluilen bij de praktijk en meer motiverend zijn voor studenten (Schmidt, 
1978). Daarom moet de opzet van het onderwijs probleemgericht zijn in plaats van disciplinegericht.

Het medisch onderwijs is onvoldoende afgestemd op de maatschappelijke veranderingen die zijn opgetreden in de begrippen "ziekte" en "ziektegedrag" en in het daarmee samenhangende functioneren van de gezondheidszorg. Het onderwijs zou zich moeten richten op de problemen van de gemeenschap en de problemen van de huidige tijd zoals hart- en vaatziekten, kanker, slijtage en ouderdom, ziekten in en rond het bedrijf en het aandeel van psychosociale factoren in het ziektepatroon, vitbreiding en verbetering van de eerste-lijnsgezondheidskunde. Voorts ligt het accent te veel op stages in ziekenhuizen. Er dient aandacht te zijn voor stages in de eerste-lijnsgeneeskunde en andere gezondheidsinstellingen (Roelink, 1980). Daarom moet de opzet van het onderwijs "communitybased" in plaats van "hospital-based" zijn.

De kennis die de basisarts zich moet eigen maken is eenzijdig cognitief en natuurwetenschappelijk gericht. Hierdoor ontstaat bij de student een eenzijdig natuurwetenschappelijk mensbeeld. Voorts heeft de student niet geleerd hoe hij met onzekerheden moet omgaan en heeft te weinig geleerd kritisch te denken onder andere over zijn eigen medisch handelen. In het onderwijs ligt het accent op medisch-technische handelingen en de training van sociale vaardigheden, attitude en persoonlijkheidsontwikkeling komen onvoldoende aan de orde. Integralie van vakgebieden als sociale geneeskunde en psychologie is daarom wenselijk (Gerritsma \& Smal, 1974). Daarom moet in het onderwijs niet vitsluitend aandacht zijn voor de medisch-technische aspecten maar ook voor psycho-sociale aspecten.

Het onderwijs wordt te veel gekenmerkt door een curriculum, dat voor alle studenten identiek is. Studenten kriigen hierdoor onvoldoende de mogelijkheid om eigen accenten te leggen en zelf te bepalen wat zij willen leren. Onderwiis moet naast een kerncurriculum de mogelijkheid geven tot differentiatie (van der Werff ten Bosch, 1973). Daarom moet meer ruimte komen voor keuze-onderwijs, waardoor de studenten eigen accenten kunnen leggen.

Het onderwijs moet een planmalig opgezet curriculum zijn, waardoor docenten en studenten op de hoogte zijn van wat geleerd moet worden. In de pré-klinische fase is hel onderwijs veelal beter gestructureerd. In de co-assistentschappen daarentegen ontbreekt een onderwijskundige structuur. Het onderwijs is afhankelijk van de betreffende vakgroepen. Een helder overzicht van doelstellingen ontbreekt (Dokter, 1984; Loor, 1988; Metz, 1984). Daarom moet het curriculum gekenmerkt worden door een onderwijskundige structuur, waarbij zicht is op de doelstellingen. 
Vanuit deze IOG-kritiek op het onderwijs, die grote overeenkomsten vertoont met de inhoud van het GPEP-rapport, zijn er de laatste jaren pogingen gedaan om het medisch onderwijs te veranderen. De onvrede met de het discipline-gericht onderwijs heeft ertoe geleid dat gezocht werd naar mogelijkheden om het vakgericht onderwijs te doorbreken en leerstof geïntegreerd aan te bieden. Rotterdam is de eerste universiteit in Nederland die een curriculum heeft ingevoerd waarbinnen de vakkenstructuur doorbroken werd. De leerstof werd geordend rondom "orgaansystemen", omdat dit meer zou aansluiten bij reële patiëntproblemen (Rotterdam, 1966). De medische faculteit in Maastricht heeft bij haar oprichting in 1974 besloten om de leerstof geintegreerd aan bod te laten komen door vit te gaan van medische problemen zoals casuistiek afkomstig uit de medische praktijk. Tevens kreeg de eerste-lijnsgeneeskunde binnen de opleiding een sterk accent (Basisfilosofie achtste medische faculteit, 1972). In Nijmegen is het discipline-gerichte curriculum vervangen door geïntegreerd thematisch onderwijs (Bernards, 1983; Nijmegen, 1970 en 1982).

Vanuit het besef dat kennis van en over ziekten niet het enige belangrijke is, maar ook de invloed van de omgeving op de patiënt, hebben medische psychologie en medische sociologie een plaats binnen het curriculum gekregen. Het belang van de relatie artspatiënt wordt meer en meer onderkend. Dit leidde tot de opzet van programma's voor gespreksvaardigheden en attitudevorming. De medische faculteit van Utrecht is een van de eerste die dergelijke programma's ontworpen heeft (Gerritsma \& Small, 1974). Deze ontwikkelingen hebben op andere universiteiten navolging gevonden.

Om meer duidelijkheid te krijgen over de inhoud van de opleiding en over datgene dat een co-assistent behoort te kunnen en te weten om een bekwame basisarts te worden, zijn aanzetten gedaan om de eindtermen voor de co-assistentschappen op concreet niveau te formuleren. In dit kader is op verzoek van het ministerie van Onderwijs en Wetenschappen het project Beleidsgericht Onderzoek Co-assistentschappen (BOC-projecl) op 1 seplember 1988 van start gegaan. Het project is uitgevoerd door de groep onderwijsontwikkeling van de Faculteit der Geneeskunde en Tandheelkunde van de Katholieke Universiteit Nijmegen. Hel doel van het project was een overzicht samen te stellen van onderwijsprogramma's in de tweede fase van alle faculteiten. Daarnaast het preciseren van de door opleiders wenselijk geachte leerdoelen, inventarisatie van de algemene, discipline-overstijgende leerdoelen en een loetsing van de wenselijk geachte leerdoelen aan de ervaringen van co-assistenten en van beginnende huisartsen in opleiding. In september 1990 heeft de eindrapportage plaalsgevonden (Melz, Bulte \& 
Poridon, 1990). Als vervolg hierop is in 1991 de Centrale Coördinalie Commissie herziening 2 de fase artsopleiding opgericht, waarin personen van de verschillende medische faculteiten zitting hebben. De taak van deze landelijke commissie is om concrete discipline gebonden en algemene eindiermen te definiëren voor de basisartsopleiding, concrete voorstellen te doen ten aanzien van de toetsing van studenten (zowel op centraal als decentraal niveau) en voorstellen te formuleren inzake de professionalisering van docenlen.

Om studenten beter voor te bereiden en het onderwijs beter of te stemmen op de praktijk zijn er diverse typen vaardigheidstrainingen opgezet. Het doel was om meer systematiek te brengen in het aanleren van praktische vaardigheden. Voorbeelden hiervan zijn het project praktisch medisch onderwijs en de opzet van het Skillslaboratorium van de medische faculteit te Maastricht (Gerritsma \& Small, 1982; Lodewick, Schmidt \& Lulofs, 1976; Metz \& Scherpbier, 1989).

De invoering van het algemeen co-assistentschap (ALCOschap) in het vijfde jaar van de studie verdient hier eveneens vermelding. Het ALCO-schap is bedoeld om studenten beter voor te breiden op co-assistentschappen door een gerichte training in algemene basale vaardigheden zoals training in vaardigheden op het gebied van anamnese, lichamelijk onderzoek, eenvoudig laboratorium onderzoek, schriiven van een stalus, het presenteren van een patiënt, hel omgaan met functionele klachten e.d. en specifieke trainingen als voorbereiding op een bepaald co-assistentschap, bijvoorbeeld omgaan met psychiatrisch onderzoek (Postma \& Metz, 1989).

Om de stap van fantoom tot werkelijke patiënten te vergemakkelijken, heeft het gebruik van "simulatiepatienten" zijn intrede gedaan. Simulatiepatienten zijn mensen die zich vit vrije wil - al dan niet tegen betaling- beschikbaar stellen als proefpersonen ter praktische vaardigheidsoefening door medische studenten (Phaff, 1987).

De ontwikkeling van computer ondersteund onderwijs [COO] maakt een geweldige ontwikkeling door. Er zijn talrijke computerprogramma's ontwikkeld om theoretisch verworven kennis toe te passen in diagnostische en therapeutische situaties. Studenten worden daardoor in een vroeg stadium bekend gemaakt met patiëntbehandelingsproblemen. Ook voor een aantal pré-klinische vakken zoals anatomie, fysiologie en celbiologie zijn programma's ontwikkeld (van Es \& van der Doef, 1990; de Jong, van Andel, Leiblum \& Mirande, 1991; Ronteltap, 1990a, 1990b; Verbeek, 1982).

De kritiek dat studenten onvoldoende voorbereid zijn op de taak van arts heeft geleid tot voorstellen om een algemeen klinische vormingsperiode in te voeren. Hierop wordt in het rapport van Borst- 
Eilers, Querido en Kock van Leeuwen (1989) uitvoerig ingegaan. De klinische vormingsperiode zou moeten plaatsvinden nadat het artsexamen is afgelegd en voordat de vervolgopleiding start. Discussies over een adequate voorbereiding zijn nog steeds volop aan de gang.

Op het gebied van de toetsing van medische vaardigheden en competentie hebben zich talrijke ontwikkelingen voorgedaan. Om toetsingen objectiever en realistischer te maken zijn mede onder invloed van internationale ontwikkelingen, gestructureerde examens ingevoerd om vaardigheden te toetsen. Bij een dergelijke examen doorloopt de student een aantal stations. Bij elk station voert de student een taak uit. Een of meerdere examinatoren beoordelen de vaardigheden van de student aan de hand van een gestructureerde checklist. Deze examens staan bekend onder de naam stationsexamens ofwel "objective structured clinical examinations" (Metz \& Scherpbier, 1989; van der Vleuten, 1989).

Concluderend kan men stellen dat her medisch onderwijs in beweging is en gewerkt wordt aan de professionalisering van een op onderwijskundige principes gebaseerde opleiding.

\subsection{Samenvatting}

In dit hoofdstuk is de ontwikkeling van het medisch onderwijs in hoofdlijnen beschreven. Voorts zijn enkele belangrijke internationale ontwikkelingen aan de orde gekomen. De geschiedenis overziende kan men constaleren dat de aandacht binnen hel onderwijs zich op verschillende terreinen richtte. Activiteiten in de 19de eeuw waren primair gericht op het bewerkstelligen van eenheid binnen de opleiding tot arts. Het begin van de twintigste eeuw kenmerkte zich door de belangstelling voor de inhoud van het onderwijs. Men streefde naar een opleiding die niet vitsluitend bio-medisch georiënteerd was, maar ook gedrags- en maatschappijwetenschappelijk. De tweede helft van de twintigste eeuw daarentegen richt zich op de vormgeving van een curriculum dat aansluit bij de behoeften van de maatschappii en daarnaast op de realisering van een studentgericht curriculum. 


\section{Opbouw van de studie geneeskunde te Maastricht}

Sedert de aanname van de Wet Herstructurering Wetenschappelijk Onderwijs (1975) bestaat de studie geneeskunde uit een zesjarig curriculum. Het eerste studiejaar, de propaedeuse, heeft een oriënterend en selecterend karakter. Aan het einde van het propaedeutisch jaar beslist de student - of de opleiding- of het verstandig is om de studie te continueren. Aansluitend aan het eerste jaar volgt het doctoraalprogramma met een cursusduur van drie jaar. Het doctoraal examen vormt daarvan de afsluiting. Het doctoraal examen wordt gevolgd door een periode van twee jaar praktisch medisch onderwijs in de dagelijkse praktijk van de gezondheidszorg. De student loopt stage op diverse klinische afdelingen van ziekenhuizen, in huisartspraktijken en in de ambulante en klinische geestelijke gezondheidszorg. Het basisartsexamen vormt de afsluiting van de studie geneeskunde. Hierna is het mogelijk zich verder te bekwamen in de sociale geneeskunde, huisartsgeneeskunde of een van de klinische medische specialismen. Afhankelijk van het soort specialis. me duurt een dergelijke opleiding twee tot zeven jaar. De vervolgopleidingen vallen onder verantwoordelijkheid van de diverse beroepsverenigingen (Dutrée, 1990). De opbouw van het medisch onderwiis is aan alle Nederlandse universiteiten identiek. Elke universiteit heeft de vrijheid om aan het onderwijs zijn eigen manier invulling te geven, passend binnen het Academisch Statuut (1973). In Nederland is het onderwijs overwegend discipline-gericht georganiseerd. De Rijksuniversiteit Limburg heeft gekozen voor een curriculumopbouw waarin de vakkenstructuur is doorbroken. Daar de onderhavige studie is uitgevoerd aan de Faculteit der Geneeskunde van de Rijksuniversiteit Limburg, volgt een beschrijving van het programma zoals dat aan deze faculteit wordt gerealiseerd. Paragraaf 3. 1 gaat in op de basisfilosofie. Paragraaf 3.2 geeft een beschriiving van het onderwijs in studiejaar $1 \mathrm{t} / \mathrm{m} 4$. In paragraaf $3.3 \mathrm{komt}$ de opzet van het onderwijs in studiejaar 5 en 6 aan de orde. In paragraaf 3.4 volgt een samenvalting. 


\section{I Basisfilosofie van de Medische Faculteit Maastricht}

Na een lange tijd van voorbereiding ging in 1974 in Maastricht de achtste medische faculteit van Nederland van start (Knegtmans, 1992). Zoals in het vorige hoofdstuk beschreven, bestond in de zeventiger jaren veel kritiek op de medische faculteiten elders in het land. Kanttekeningen werden geplaatst bij het opleidingsaanbod, dat onvoldoende gericht was op de veranderende samenleving. Daarnaast richtte een deel van de kritiek zich op de traditionele aanbieding van de leerstof, waarbii nauwelijks rekening gehouden werd met vernieuwde inzichten binnen de onderwijskunde en leerpsychologie. Het streven was om in Maastricht een "student-centered" en "community-centered" opleidingsprogramma te realiseren. De Commissie voorbereiding achiste medische faculteit heeft in haar "Basisfilosofie" (1972) verwoord op welke wijze het onderwijs gestalte zou moelen kriigen:

"De medische faculteit Maastricht heeft niet alleen tot taak richting en kwaliteit van het onderwijs te bewaken; zij zal tevens het systeem van onderwijs en gezondheidszorg verder moeten beinvloeden door onderzoekend en experimenterend bij te dragen aan een zo goed mogeliike structuur en werkwijze van de gezondheidszorg. Onderzoek is nodig inzake vraag en aanbod en met betrekking tot kwesties als taakafbakening en onderlinge afstemming, ook al in de opleiding ("beeld van de arts"), van de naar richting en niveau (integratie Wetenschappelijk Onderwijs en Hoger Beroepsonderwijs) verschillende werkers in de gezondheidszorg en voorts ten aanzien van athankeliikheid van somatische verschiinselen aan de ene en psychisch/maatschappelijke klachren aan de andere kant. Speciale aandacht en onderzoek moet worden besteed aan de opleiding van artsen voor het eerste echelon, gezien de ontwikkelingen op dit terrein. Voorop gesteld wordt, dat het noodzakelijk is dat de arts grondige kennis en inzicht in de somatische aspecten van de geneeskunde heeft en dus bij elke student het vermogen moet worden ontwikkeld om in dit gebied problemen te analyseren en tot oplossing brengen. Het somatische vormt immers het wezenskenmerk van de geneeskundige inbreng in de gezondheid en welzijnszorg. Daarnaast is echter een betere scholing van de (aanstaande) arts in de in gedrags- en sociale wetenschappen een duidelijk vereiste. Dit accent wordt niet zozeer gelegd "ter ontwikkeling van een goede attifude van de arts", maar zal in de eerste plaats moeten dienen als ondergrond voor de lprobleem/benadering van circa $70 \%$ niet-(uitsluitend) somatische klachten waarmee de huisarts in zijn functie nu wordt geconfronteerd. Hierbii komt, dat de steeds meer complexe structuur van de in vele 
specialismen onderverdeelde curatieve en prevenfieve geneeskunde en de navenante ontwikkeling binnen het gebied van de welzijnszorg steeds zwaardere eisen gaan stellen aan de psychosociale begeleiding van de patiënt, zowel bij de verwijzing in het verticale (2e en $3 e$ echelon) als in het horizontale (welziinszorg) vlak. Teamvorming van de arts met niet-medische deskundigen, de ontwikkeling van groepspraktijken en de bouw van speciale gezondheidscentra liggen hierbij in de lijn der verwachting. Naast de speciale aandacht voor het le echelon zullen in het nieuwe curriculum de andere richtingen binnen de gezondheidszorg /namelijk de curatiefspecialistische zorg, de maatschappelijk en geestelijke gezondheidszorg en het medisch wetenschappelijk onderzoek) voldoende aandacht moeten krijgen".

\subsection{Opzet van de eerste vier studiejaren}

Vanuit de doelstelling, zoals verwoord in de basisfilosofie, heeft de faculteit invulling trachten te geven aan het onderwijsprogramma. Bii de inrichting van het curriculum is zoveel mogeliik rekening gehouden met onderwijskundige principes. Als onderwijsmethode werd gekozen voor probleemgestuurd onderwijs. Een onderwijsbenadering waar "problemen" uit de praktijk van de gezondheidszorg het vitgangspunt voor studie zijn. In deze methode heeft de student een grote mate van zelfstandigheid en eigen verantwoordelijkheid bij het inrichten van de studie (Barrows \& Tamblyn, 1980; Schmidt, 1983; Schmidt \& de Volder, 1984). Dit heeft geresulteerd in een curriculum dat duidelijk anders is dan elders in Nederland het geval is (Greep, 1979; Schmidt, 1978; Tiddens, Willighagen \& Wiinen, 1975).

Deze methode is oorspronkelijk ontwikkeld aan de McMaster University in Hamilton Canada (Hamilton, 1976; Neufeld \& Barrows, 1974; Sweeney \& Mitchell, 1975]. De ideeën van McMaster University zijn van grote invloed geweest op het Maastrichtse programma.

In hel programma van jaar $1 \mathrm{t} / \mathrm{m} 4$ slaan niet de verschillende medische vakgebieden maar medische probleemgebieden ofwel thema's centraal (Schmidt, 1978). De basis- en klinische vakken komen aan de orde in hel kader van deze thema's. Het onderwijsprogramma is daartoe verdeeld in blokken, die elk vier of zes weken duren. Elk blok is opgezet rondom een bepaald thema, bijvoorbeeld "Aanval en afweer" (blok 1.4), "Groei en differentiatie" (blok 2.5), "Pijn" (blok 3.5) en "Bloedverlies" (blok 4.5). Gedurende elk blok werken 8 à 10 studenten twee keer per week twee uur samen in een onderwijsgroep. Een dergelijke groep wordt op aselecle wijze uit de jaargroep samengesteld en wisselt per blok. Dit 
heeft als voordeel dat sfudenten in de loop van hun studie veel medestudenten leren kennen en met collega's leren samenwerken die verschillende of uiteenlopende kennis, vaardigheden, ervaringen en opvattingen hebben. Bovendien blijven de gevolgen van een eventueel slecht functionerende samenwerking beperkt tot een overzienbare periode. Aan iedere onderwijsgroep is een staflid als begeleider, tutor genoemd, toegevoegd. Het is de taak van de futor de kwaliteit van het werken in de groep te bewaken en te bevorderen. Een probleem - ook wel taak genoemd - is het startpunt van het leerproces. In de loop van vier studiejaren werkt de student aan ongeveer 300 problemen, die gerelateerd zijn aan de praktijk van de gezondheidszorg. Een probleem bestaat vit een verzameling fysische, biologische, psychologische of sociale verschijnselen die op een of andere wijze met elkaar samenhangen. De taak van de studenten is het probleem te analyseren door verklaringen van en oplossingen voor de betreffende problemen te bedenken. Dat gebeurr door ideeën en veronderstellingen die naar aanleiding van een probleem bij hen opkomen in een gestructureerde discussie te expliciteren. Het resultaat van de discussie is een beschrijving van de principes, processen of mechanismen die volgens de studenten aan het probleem ten grondslag zou kunnen liggen evenals van de probleemoplossingen. Tijdens de analyse zullen vragen opkomen over een aantal zaken die niet begrepen, verhelderd of verklaard zijn. Dit vormt de basis voor het formuleren van leerdoelen voor zelfstudie. In figuur 1 is een voorbeeld van een probleembeschrijving met bijbehorende leerdoelen opgenomen.

Figuur 1 Voorbeeld van een probleembeschrijving met biibehorende leerdoelen (Bron: blok 2.6 "Geboren en getogen" studiejaar 1990/1991)

"De laatste jaren is Ellen behoorlijk snel gegroeid. Ze was altijd al een lange meid, maar ze is nu 11 jaar en met haar $164 \mathrm{~cm}$ steekt ze een kop boven de rest van de klas uit. De mensen schatten haar altijd ouder en dat is soms vervelend. Wat moet dat later worden?

De pubertiid moet nog komen.."

Leerdoelen:

1. normale groei van het kind

2. regelmechanisme van groei en ontwikkeling

3. wat betekent het voor iemand om door zijn lengte een buitenbeentje te zijn. 
In de tijd die verloopt tussen twee onderwijsgroepsbijeenkomsten, gewoonlijk enkele dagen, werken studenten individueel of met elkaar aan de leerdoelen door het bestuderen van vakliteratuur of tijdschriften, het bekijken van videobanden en het raadplegen van docenten. In een volgende groepsbijeenkomst gaan de studenten na in hoeverre zij het probleem nu beter begrijpen en zouden kunnen oplossen. Ook is binnen elk blok plaats ingeruimd voor plenaire activiteiten zoals lezingen en vragenuren. Daarnaast worden er practica georganiseerd om vaardigheden te oefenen, bijvoorbeeld het uitvoeren van een gynaecologisch onderzoek, het voeren van een gesprek. Voorts vindt regelmatig attitude-onderwijs plaats. De activiteiten sluiten zoveel mogelijk aan bij de thematiek van het blok (Moust, Bouhuijs \& Schmidt, 1989). Bii elk blok hoort een blokboek, waarin organisatorische en inhoudelijke informatie over het onderwijs is opgenomen. De problemen of taken die voortvloeien uit het thema, vormen de kern van het blokboek. Daarnaast bevat hel blokboek de jaar- en blokdoelstellingen, het rooster, beschrijvingen van lezingen en practica, een lijst met beschikbare audio-visuele middelen, aanbevolen literatuur en namen van deskundigen op de relevante vakgebieden die geraadpleegd kunnen worden ingeval er inhoudelijke problemen met de leerstof zijn. Aan het einde van elk blok vindt er een toets plaats, waarvan de inhoud gerelateerd is aan het thema. Naast de verplichte, reguliere blokken zijn er gedurende de eerste vier jaar van de studie vijf blokken gereserveerd voor keuze-onderwijs. Hieraan geeft de student zelf invulling met dien verstande dat de faculteit vooraf diens plan in deze moet goedkeuren.

\subsection{Opzet van studiejaar 5 en 6}

Tiidens jaar 5 en 6 van de studie ligt het accent op het praktisch medisch onderwijs (PMO) en lopen de studenten stage in de praktijk van de gezondheidszorg. Er is geprobeerd dit onderwijs op een planmatige wijze te ontwikkelen. Om te benadrukken dat het gaat om "leerplaatsen" spreekt men in Maastricht bij voorkeur van stages en/of praktisch-medisch onderwijs in plaats van de elders veelal gehanteerde term "co-assistentschappen". In dit proefschrift wordt zowel de term stage als co-assistentschap gehanteerd om te refereren aan leerplaatsen.

De visie van de faculteit op de gezondheidszorg, verwoord in de basisfilosofie (1972), vormt de basis voor de inrichting van het praktisch medisch onderwijs. De medische faculteit zou speciale aandacht moeten besteden aan de opleiding van artsen voor het 
eerste echelon, huisartsen dus. In het vijfde jaar is daarom drie maanden gereserveerd voor een stage in de huisartspraktijk. De ruimte voor een dergelijke lange stage, relatief ten opzichte van elders in het land, is gecreëerd door de andere klinische stages van kortere duur te laten zijn dan aan andere Nederlandse faculteiten gebruikelijk is. De stage praklisch medisch onderwijs in de huisartspraktijk (PMO-H) is zeer gestructureerd. De student verblijft twintig uur per week, verdeeld over vier dagen per week in een huisartspraktijk en wordt gekoppeld aan een huisartsopleider. De resterende liij is bestemd voor vitwerking van opdrachien en voor zelfstudie. De huisartsopleider is verantwoordelijk voor het onderwijs op de stageplaats. Tussen de opleider en student vindt dagelijks een leergesprek plaats op basis van de door de student gemaakte patiëntverslagen. Elk leergesprek wordt afgesloten met afspraken voor zelfstudie. Daarnaast vindt wekelijks een zogenaamde terugkomdag op de universiteit plaats. Tijdens deze dagen wisselen de studenten ervaringen uit en komen thema's (bijvoorbeeld verslaving, omgang met buitenlandse patiënten, de oudere mens) en patiëntpresentaties aan de orde. De studenten stellen zelf de onderwerpen van de terugkomdagen vast. Er wordt gewerkt in kleine groepen onder begeleiding van een huisarts (Bouhuijs, 1983; Bouhuijs, Brouwer \& Mol, 1980; op 't Root, 1990).

Daarnaast vindt er een zogenaamde psycho-medische stage (PMO-PMS) van twee maanden plaats in ambulante en klinische instellingen voor geestelijke gezondheidszorg zoals een Regionaal Instituut Ambulante Geestelijke Gezondheidszorg (RIAGG), Psychiatrisch Afdeling van een Algemeen Ziekenhuis (PAAZ), Psychomedisch streekcentrum. Tijdens deze stage voert de student zelfstandig gesprekken mel en onderzoek van patiënten/cliënten en verricht al de hieruit voorkomende handelingen onder supervisie uit. Voorts is de słudent aanwezig bij patiënt/cliëntbesprekingen in de diverse behandelingsteams. Tijdens deze stage vindt er aanvankelijk twee - later eenmaal wekelijks in groepen van 10 studenten onder begeleiding van een tutor een terugkommiddag plaats. Voor de inhoud van deze middagen zijn de studenten en tutoren gezamenlijk verantwoordelijk. Naast aandacht voor het persoonlijk en beroepsmatig functioneren van de student wordt aandacht besteed aan casuistiek. De behandeling van de casus vindt patiënt- of themagericht plaats. $\mathrm{Bij}$ een patiëntgerichte bespreking gaat de groep na welke stappen van de basale hulpverlening met betrekking tot de probleemoplossing aan de orde zijn gekomen. Bij themagerichte bespreking wordt de ingebrachte casus verklaard aan de hand van literatuur. 
Aanvankelijk was het de bedoeling om de klinische stages een totaal hernieuwde invulling te geven, die aansloot bij de basisfilosofie van de medische faculteit. Het oorspronkelijke plan hield in dat studenten gedurende twee periodes van zes maanden gestationeerd zouden worden op een zogenaomde thuisbasis, respectievelijk de afdelingen algemene heelkunde en interne geneeskunde. Vanuit deze basis zouden de studenten een aantal patiënten volgen inclusief overplaatsing naar andere afdelingen of bij consulten. Het ontwerp bleek niet haalbaar. Het idee van de "thuisbasis" met uitzwermende studenten over diverse afdelingen stuitte op bezwaren van organisalorische aard. De discipline-overschrijding strandde op de sterke disciplinaire grenzen binnen de ziekenhuisorganisatie. Een groot deel van het onderwijsprogramma vloeide niet direct voort vit de rouline-gezondheidszorgtaken, hetgeen eveneens op problemen stuitte. Het gevolg was dan ook dat het oorspronkelijke plan nooit gehonoreerd is. Dif leidde tot een opzet van stages in ziekenhuizen die sterke gelijkenis vertoont met de opzet van de coassistentschappen elders. Afgezien van het PMO-H en PMO-PMS lopen de studenten stage op de afdelingen van interne geneeskunde, chirurgie, kindergeneeskunde, neurologie, gynaecologie/obstetrie en de zintuigvakken (Onderwijscommissie, 1984). De stages vinden plaats op verschillende afdelingen van het Academisch Ziekenhuis Maastricht (AZM) en van geaffilieerde ziekenhuizen, dat wil zeggen niet-academische ziekenhuizen die een samenwerkingsverband op het gebied van onderwijs hebben 'met een academisch ziekenhuis. Daarnaast is er in het vijfde en zesde jaar van de opleiding 13 weken gereserveerd voor keuze-onderwijs. Het plannen hiervan gebeurt op eigen initiatief van de studenten in de perioden waarin geen co-assistentschap plaatsvindt. De invulling van het keuze-onderwijs is vrij maar er dient vooraf ter goedkeuring een plan worden voorgelegd aan de projectgroep keuze-onderwijs. In tabel 1 staat een overzicht van het soort stages en de duur van de stages die studenten lopen aan de Medische Faculteit Maastricht. 
Interne geneeskunde (inclusief cardiologie en pulmonologie)

Chirurgie (inclusief urologie en orthopaedie)

Gynaecologie/obstetrie

12 weken

Kindergeneeskunde

8 weken

Neurologie

6 weken

Oogheelkunde

4 weken

3 weken

Keel, neus- en oorheelkunde (KNO)

3 weken

Dermatologie

3 weken

Praktisch medisch onderwijs in de huisartspraktijk (PMO-H)

12 weken

Praktisch medisch onderwijs in psycho-medische setting (PMO-PMS)

Keuze-onderwiis

Tabel 1 Overzicht van het soort stages en de duur van de stages aan de Medische Faculteit Maastricht (gegevens 1991)

Aan het begin van het vijfde jaar krijgt elke student een stagespoor toegekend, waarin de volgorde van de stages is opgenomen. Het stagespoor varieert per student met dien verstande dat de student begint met of huisartsgeneeskunde of interne geneeskunde of chirurgie. Hiervoor is gekozen omdat vanuit deze disciplines een brede oriëntatie op het vakgebied mogelijk is. Het hiernavolgende beschrijft welke activiteiten studenten verrichten tijdens de stages.

Voor de aanvang van elke stage ontvangt de student een stageboek. In het stageboek is organisatorische en inhoudelijke informatie opgenomen zoals de doelstellingen van de stage, relevante literatuur en leermiddelen, thema's van onderwijsbijeenkomsten en voordrachten en vragen voor zelfevaluatie. Het stageboekje fungeert als "spoorboekje" en beschrijft wat de student kan verwachten tijdens de stage. De stagecoördinator stelt het stageboek jaarlijks bij.

Elke stage heeft een stagecoördinator, die verantwoordelijk is voor de algemene begeleiding van de student en als aanspreekpunt fungeert voor de student indien er vragen en/of problemen zijn. De stagecoördinator houdt regelmatig een gesprek met de student over de voortgang. Hiervoor informeert de coördinator bij de andere artsen, die met de student gewerkt hebben. De stagecoördinator draagt daarnaast zorg voor de planning van de stage, organisatie van inhoudelijke bespreking e.d.

Elke stage begint mel een introductie, waar allerlei organisatorische zaken aan de orde komen. De coördinator verzorgt de 
introductie. Hij houdt een inleidend gesprek en bespreekt het komende programma. De sludenten ontvangen een rooster waarin een overzicht van alle activiteiten is opgenomen.

Het doel van elke stage is dat studenten vaardigheden en kennis leren toe te passen in de praktijk van de gezondheidszorg. Daartoe verblijft de student tijdens elke stage op de polikliniek en de verpleegafdeling. De werkzaamheden van de student op de polikliniek bestaan in hoofdzaak uit het statussen van nieuwe patiënten en uit het observeren van de specialist tijdens zijn werkzaamheden. Bij hel verrichten van de intake van nieuwe patiënten krijgt de student gelegenheid om de anamnese af te nemen en lichamelijk onderzoek te verrichten bij de patiënt. De student noteert de bevindingen en doet voorstellen voor behandeling, therapie of verder onderzoek. De student bezit geen medische bevoegdheid en werkt altijd onder verantwoordelijkheid van een supervisor. De supervisor neemt dan ook opnieuw de anamnese af, voert het lichamelijk onderzoek uit en rondt het consult met de patiënt af. Op een vastgesteld tijdstip vindt er een nabespreking met de studenten plaats. Observatie van professioneel handelen bevat belangrijke leermomenten, daarom is het belangrijk dat de student de arts regelmatig observeert bij zijn werkzaamheden. Het is de bedoeling dat eventuele vragen over het handelen van de arts door de student genoteerd worden. Bij de nabespreking kan de student om verduidelijking en/of toelichting vragen.

Tijdens zijn verblijf op de verpleegafdeling neemt de student bij opgenomen patiënten een anamnese af, verricht lichamelijk onderzoek en diagnostische handelingen, bijvoorbeeld interpreteren van laboratoriumgegevens en van onderzoeksuirslagen en stelt een therapeutisch plan op, bijvoorbeeld medicatie, dieet. Deze werkzaamheden verricht de student onder begeleiding van de verantwoordelijke zaalarts.

Bii de snijdende disciplines vinden pre-operatieve besprekingen en operaties plaats. De student maakt voor de operatie van een operatie-patiënt een status. De student neemt de anamnese zelfstandig af en verricht het onderzoek in aanwezigheid van de afdelingsassistent. De evaluatie en uitstippeling van het verdere programma vindt plaats tijdens de pre-operatieve besprekingen. Tijdens deze bespreking presenteert de student de betreffende patiënt-casus. In de regel woont de student de operatie bij van de patiënt die hij zelf pre-operatief heeft nagekeken. In overleg is het mogelijk om bij ingrepen te assisteren.

Dagelijks vinden er afdelingsvisites plaats, waarbij de zaalarts en een verpleegkundige een ronde maken over de afdeling. De studenten zijn hierbij aanwezig. De activiteiten van de studenten variëren van observeren van de arts tot in aansluiting op de visite 
het zelf verrichten van voorkomende hand- en spandiensten, bijvoorbeeld infuus inbrengen, bloed afnemen, hechtingen verwijderen. De afdelingsvisites zijn bij uitstek geschikt voor "bedside-teaching", waarbij de zaalarts aan de hand van concrete problemen uitleg geeft over ziektebeelden.

Op elke afdeling vinden er diverse patiëntbesprekingen plaats zoals ochtendrapport, overdrachtsbesprekingen en voorbesprekingen van opgenomen en te opereren patiënten. Studenten zijn hierbij aanwezig. Daarnaast vinden er binnen elke stage disciplinegebonden besprekingen plaats met de patholoog-anatoom en de röntgenoloog. De frequentie van de besprekingen wisselt per discipline en ziekenhuis. Röntgenbesprekingen vinden veelal dagelijks plaats. Tijdens dergelijke besprekingen bespreekt de röntgenoloog de rönlgenfoto's van patiënten in aanwezigheid van de behandelende artsen. Pathologie-besprekingen vinden veelal wekelijks plaats aan de hand van coups (folo's) en macroscopisch preparaten. Het is de bedoeling dat de student ook van deze bijeenkomsten een aantal bijwoont.

In een aantal stages draait de student nacht-, avond- en weekenddiensten. De student assisteert de dienstdoende arts-assistent of specialist bij voorkomende werkzaamheden. Voor dienstdoende coassistenten zijn faciliteiten (slaapkamers, restauratieve voorzieningen) aanwezig. Tijdens deze diensten worden studenten geconfronteerd met acule patiëntproblemen.

De stagecoördinator organiseert onderwijsbijeenkomsten die speciaal voor studenten bedoeld zijn. Tijdens dergelijke bijeenkomsten houden deskundigen van de betreffende discipline een voordracht of de co-assistenten bereiden zelf een praatje voor. Het is de bedoeling dat er wekelijks tenminste één voordracht plaatsvindt. Het aanlal voordrachten wisselt per co-assistentschap. Daarnaast vinden bij verschillende vakgroepen refereeravonden plaats, primair bestemd voor de specialisten en assistenten in opleiding, maar ook voor co-assistenten toegankelijk. Artsen bespreken en demonstreren op dergelijke avonden probleempatiënten en/of gastsprekers houden wetenschappelijke voordrachten.

In de stages interne geneeskunde, chirurgie en gynaecologie/obstetrie die gelopen worden in AZM vinden per twee weken attitude-bijeenkomsten plaats. Het doel van dergelijke bijeenkomsten is begeleiding en stimulering van het proces van bewustwording. Elke bijeenkomst begint met een verhaal van een student omtrent een gebeurtenis of ervaring tijdens de stage. De aandacht wordt geconcentreerd op de betekenis van een en ander voor de student. Bijvoorbeeld: "Ik heb er zo'n moeile meer zoals wij reclaal moeten toucheren". "Ik was bij het overlijden van een patiënt op de OK". 
De inhoud van het verhaal wordt secundair en vormt als het ware het decor van het bewustwordingsproces. De eigenlijke inhoud van de bijeenkomsten is gericht op de visie, belevingen en handelswijze van de betrokkenen zelf. De manifeste attitude wordt niet op waarde beoordeeld, maar neutraal behandeld. De nadruk ligt op de gevoelens, belevingen en reakties die bij ervaringen horen. Studenten werken in kleine groepen onder begeleiding van een gedragswetenschapper en een arts.

Op de afdeling gynaecologie/obstetrie, interne geneeskunde en kindergeneeskunde van het AZM vinden medisch-ethische besprekingen plaats. Hiertoe selecteren co-assistenten klinisch of poliklinisch patiëntencasus waarbij het medisch beleid naar hun mening aanknopingspunten biedt voor medisch-ethische reflexie. Ze stellen eigen ethisch-maatschappelijk waarde-oordelen en eigen ervaringen ter discussie, bijvoorbeeld medische consumptie, standpunten euthanasie. Studenten werken in kleine groepen onder begeleiding van een arts en ethicus.

Gedurende de stage zal de student naar aanleiding van patiënten op bepaalde probleemgebieden stuiten, bepaalde hiaten in zijn voorkennis ontdekken en over bepaalde zaken meer willen weten op grond van observaties van artsen. Op momenten dat er geen activiteiten gepland zijn, heeft de student gelegenheid voor zelfstudie. Op elke afdeling zijn hiervoor leermiddelen in de vorm van video's, boeken en tijdschriften beschikbaar en is er een studieruimte.

Daarnaast vinden er in elke stages activiteiten plaats die gebonden zijn aan de betreffende discipline zoals verblijf op de verloskamer en op de afdeling Eerste Hulp bij Ongelukken (EHBO).

Aan het einde van elke stage krijgt de student een stagebeoordeling. Deze bestaat uit een oordeel voor het functioneren tijdens de stage zowel wat betreft praktijk als theorie. Toetsing van medische kennis en competentie vindt plaats aan de hand van casusmateriaal en/of patiëntproblemen. De beoordeling is voldoende als de student goed heeft gefunctioneerd, alle verplichte activiteiten heeft bijgewoond en de toets voldoende heeft gemaakt.

\subsection{Samenvatting}

In dit hoofdstuk is de opzet van het medisch onderwijs beschreven. Hierbij is vitgegaan van het onderwijsprogramma van de Faculteit der Geneeskunde van de Rijksuniversiteit Limburg. De opzet van het programma wijkt af van dat van de universiteiten elders in Nederland. Het onderwijs in de eerste vier studiejaren is ingericht volgens de principes van probleemgestuurd leren. Aangegeven is op welke 
wijze deze principes gerealiseerd zijn in het programma. Vervolgens is een beschrijving gegeven van klinische stages die in studiejaar 5 en 6 plaatsvinden. 


\section{Evaluatie van co-assistentschappen}

Zoals eerder betoogd had de Faculteit der Geneeskunde behoefte aan een instrument om de kwaliteit van co-assistentschappen te meten. Een zorgvuldige meting, zo was de overtuiging, zou een bijdrage kunnen leveren aan de bevordering van de kwaliteit van het onderwijs. Een adequaat gebruik en toepassing van een dergelijk instrument vraagt echter om een institutionele context waarbinnen evaluatie mogelijk is, dat wil zeggen de aanwezigheid van een infra-structuur waarbij verantwoordelijkheden en taken van docenten en commissies zijn vastgelegd en ingebed in de organisatie. Dit hoofdstuk beschrijtt de context waarbinnen het instrument moet fungeren. Daartoe $z a l$ in paragraaf 4.1 een beschrijving worden gegeven van het organisatieklimaat en de visie van docenten op onderwijs. Evaluatie kan enerziijs vanuit een produktgerichte benadering plaatsvinden en anderzijds vanuit een procesgerichte benadering. Hierop wordt in paragraaf 4.2 ingegaan. In paragraaf 4.3 volgt een samenvatting.

\subsection{Typering van de onderwijsorganisatie en de visie op onderwijs}

De invoering van een gestandaardiseerde evaluatiemethode naar onderwijskundige maatstaven stelt bepaalde eisen aan de context. De context kan men enerzijds beschrijven aan de hand van het organisatieklimaat waarbinnen een instrument moet fungeren en anderzijds aan de hand van rolopvaltingen van docenten. Aan de hand van beschrijvingen hierover van Darling-Hammond, Wise en Pease (1983) wordt een typering gegeven van het organisatieklimaat en de rolopvattingen van docenten die betrokken zijn bij coassistentschappen.

Darling-Hammond et al. (1983) maken onderscheid in twee organisatiemodellen en vier manieren waarop naar het onderwijsproces en met name naar de rol van de docent gekeken kan worden. Zij maken onderscheid in rationalistische en natuurlijke organisatiemodellen. Een rationalistisch organisatiemodel kenmerkt zich door een hiërarchische opbouw, een centrale besluitvorming, een 
uitgewerkte regelgeving en een functionele scheiding in docentrollen. In een dergelijke organisatie zijn programma's planmatig en modelmatig opgezet. Beslissingen worden centraal in bestuursorganen genomen en niet door individuele docenten. In de context van een rationalistisch model zal informatie over onderwijsprogramma's worden verzameld. In een natuurlijk organisatiemodel ligt de verantwoordelijkheid voor het onderwijs decentraal, vooral bij de individuele docent. De docent bezit de autonomie en de organisatie creëert slechts een aantal randvoorwaarden om globale opleidingsdoelen te bereiken. In die situatie zal de evaluatie zich richten op de individuele docent en zijn programma (Parlett \& Hamilton, 1977).

Voorts onderscheiden Darling-Hammond et al. (1983) de volgende rollen c.q. functies van docenten over onderwijs: "teaching as labor", "teaching as craft", "teaching as profession" en "teaching as art". Bij teaching as labor is de docent verantwoordelijk voor hel vitvoeren van het onderwijsprogramma zoals dar door anderen ontworpen is. De leiding formuleert doelen, kiest een strategie, zorgt voor voldoende middelen en controleert of bepaalde nauw omschreven taken op correcte manier zijn uitgevoerd. De docent moet het onderwijs verzorgen op de in het programma voorgeschreven manier en daarbij rekening houden met de regels en voorschriften die binnen de opleiding ziịn opgesteld. De instelling verwacht niet van de docenten dat zij op eigen initiatief wijzigingen in het programma aanbrengen. Bii teaching as craft wordt de docent gezien als vakman: iemand die over de nodige specialistische kennis en technieken beschikt om zijn vak uit te oefenen en die zelfstandig in bepaalde situaties keuzes kan maken om de door de instelling voorgeschreven doelen te bereiken. De eindtermen van de opleiding zijn redelijk nauw omschreven. Het is de taak van de docent dat leerlingen aan deze eisen kunnen voldoen, hetgeen impliceert dat de docent slechts binnen beperkte marges mogelijkheden heeft om de leerstof te kiezen. Bii teaching as profession wordt de docent gezien als een professional, die in principe het best geïnformeerd is over wat nodig is en hoe dat bereikt kan worden. Hij is nauw betrokken bij de opzet van het programma, of bepaalt zelf de inhoud van het programma. Van de docent wordt verwacht dat hij zowel over voldoende didactische kennis beschikt om een programma uit te voeren, als over voldoende inzicht om zelfstandig beslissingen te nemen over de inhoud en werkvormen binnen het programma. Het is de taak van de organisatie om didactisch en vakinhoudelijk bekwame docenten aan te stellen en deze van voldoende middelen te voorzien om hun werk goed uit te voeren. Bij teaching as art is de docent als creatief kunstenaar volledig verantwoordelijk voor de inhoud en vitvoering van zijn programma. Hoe het onderwijspro- 
ces verloopt is in wezen onvoorspelbaar en is in deze opvatting sterk afhankelijk van de persoon die doceert. De onderwijsorganisatie heeft slechts tot taak de voorwaarden te scheppen waaronder docenten hun werk in alle vrijheid verrichten. Het essentiële verschil tussen deze opvattingen is de mate van autonomie van de docent. Bij teaching as labor en teaching as craft is de autonomie van handelen vrijwel afwezig. Bij teaching as profession beschikt de docent over zekere mate van autonomie, maar binnen bepaalde grenzen. $\mathrm{Bij}$ teaching as art is de docent volledig autonoom in zijn handelen.

Veelal zal een rationalistisch organisatiemodel samengaan met rolopvattingen waarbij de docent minder autonoom kan handelen (teaching as labor/craft). Daar zowel de organisatie, als de inhoud en de vitvoering van het onderwijs tot in detail beschreven en vastgelegd zijn past hierbii een evaluatie-benadering met een cursus- of docentoverstijgend karakter. Een modelmatige evaluatiebenadering ligt hier voor de hand, waarbii gebruik gemaakt wordt van standaard evaluatie-instrumenten, die voor alle disciplines identiek zijn. Een natuurlijk organisatiemodel zal gewoonlijk samengaan met docentenopvattingen waarbij de docent autonoom kan handelen (teaching as profession/art). De organisatie, de inhoud en de vitvoering zullen niet expliciet beschreven zijn evenmin als de bevoegdheden van docenten. In dit kader zal evaluatie vooral een bijdrage moeten leveren aan de besluitvorming van de individuele docenten. Een modelmatige evaluatiebenadering is minder voor de hand liggend dan een holistische benadering, waarbij instrumenten gebruikt worden die zijn toegespitst op de setting van de individuele docenten. In figuur 2 is de relatie tussen organisatievorm, opvatting over onderwijs en de evaluatiebenadering schematisch weergegeven.

Relatie tussen organisatievorm, onderwijsopvatting en evaluatiebenadering

\begin{tabular}{|lll|}
\hline Organisatievorm & Onderwijsopvatting & Evaluatiebenadering \\
\hline Rationalistisch model & $\begin{array}{l}\text { Teaching as labor } \\
\text { Teaching as craft }\end{array}$ & $\begin{array}{l}\text { Modelmatige benadering } \\
\text { Gestandaardiseerde } \\
\text { evaluatie }\end{array}$ \\
Natuurlijk model & $\begin{array}{l}\text { Teaching as profession } \\
\text { Teaching as art }\end{array}$ & $\begin{array}{l}\text { Holistische benadering } \\
\text { Niet-gestandaardiseerde } \\
\text { evaluatie }\end{array}$ \\
\hline
\end{tabular}


De traditionele situatie in de tweede fase van hel medisch onderwijs kan getypeerd worden als een natuurlijk organisatiemodel waarbij de docenten volledig autonoom handelen. De onderwijskundige aanpak werd niet op een centraal niveau bepaald maar door de betreffende vakgroep. Gevolg was dat klinische co-assistentschappen zich grotendeels onttrokken aan de invloed van de faculreiten. Dit blijkt uit het feit dal voor stages in ziekenhuizen geen duidelijk omschreven opleidingsconcept aanwezig was en er weinig formele voorschriften waren omtrent de invulling van de opleiding. ledere ziekenhuisafdeling of vakgroep gaf een eigen invulling aan de opleiding van studenten. Het leren verliep hoofdzakelijk volgens het meester-gezel principe of het gilde-model, waarbij de student studeerde onder direcle verantwoordelijkheid van de betreffende specialist, veelal een hoogleraar, die de inhoud van de opleiding bepaalde. De opleider wist wat goed voor de student was en de student leerde door "mee te lopen" met de opleider. Er werd vertrouwd op de deskundigheid van de opleider. Doelstellingen waren niet expliciet geformuleerd. Daarenboven waren er verschillen in opvattingen en vitvoering te constateren tussen de academische ziekenhuizen en geaffilieerde ziekenhuizen (zie hoofdstuk 2).

Echter de laatste jaren is in Nederland een tendens waarneembaar, waarbij men streeft naar een meer onderwijskundige benadering van co-assistentschappen. Dit blijkt uit het feit dat er meer aandacht is voor de functies van co-assistentschappen, de leereffecten van co-assistentschappen en de criteria die aan co-assistentschappen gesteld moeten worden (Scherpbier \& Metz, 1989.) Ook worden er pogingen gedaan om het onderwijs beter te structureren, bijvoorbeeld door eindtermen voor de co-assistentschappen op concreet niveau te formuleren. Een duidelijke aanzet hiertoe wordt gegeven in het in hoofdstuk 2 besproken Beleidsgericht Onderzoek Co-assistentschappen (Metz et al., 1990). Naar aanleiding van dit BOC-project is er bij verschillende medische faculteiten meer oog gekomen voor de doelstellingen- en de toetsingsproblematiek. Een ander signaal is dat in de taakstelling van klinische docenten, naast hun taak in de patiëntenzorg, vildrukkelijker aandacht gevraagd wordt voor formele onderwijsactiviteiten: de begeleiding van studenten en de coördinatie van onderwijs. Ook is men meer oog gaan krijgen voor de arts als opleider en dientengevolge voor de didactische scholing van opleiders. Dit blijkt ook vit de groei die de Nederlandse Vereniging voor Medisch Onderwijs de laatste jaren doormaakt en de geluiden die er zijn om het medische onderwijs "professioneler" op te zetten (van der Heiden, 1990). Op basis hiervan kan geconcludeerd worden dat er in de setting waarbinnen co-assisrentschappen gerealiseerd worden een verschuiving waarneembaar 
is van het natuurlijke naar een rationalistisch organisatiemodel en docentrollen waarbij de docent niet meer volledig autonoom kan handelen.

In het hiernavolgende wordt expliciet aandacht besteed aan elementen van de organisatie van het.klinisch onderwijs aan de Faculteit der Geneeskunde van de Rijksuniversiteit Limburg die illustreren dat daar gestreefd wordt naar een rationalistisch organisatiemodel waarbij bevoegdheden van docenten en commissies duidelijk beschreven en afgebakend zijn.

Binnen de faculteit hebben de studierichtingscommissie (SRC) en de onderwijscoördinatiecommissie (OCC) een belangrijke functie. De SRC, die conform artikel 80 van de WWO is ingesteld, fungeert als centrum van hel gehele facultaire onderwijs. Zij vervult zowel beleidsvoorbereidende als -uitvoerende taken. De SRC is primair belast met strategisch onderwijsbeleid. De OCC is een commissie van de SRC. Zij draagt zorg voor de organisatie en coördinatie van het onderwijs en houdt tevens toezicht op de nadere regeling en vitvoering van het onderwijs. Een groot aantal partijen participeert in de co-assistentschappen, zoals de klinici binnen de diverse ziekenhuisafdelingen, de bestuurlijke organisaties binnen de faculteit, en de diverse ziekenhuizen zowel het Academische Ziekenhuis Maastricht als de geaffilieerde ziekenhuizen. Om tot een adequate inhoudelijke en organisatorische afstemming te komen zijn er door de SRC en OCC op verschillende niveaus ten behoeve van het klinisch onderwijs, zowel stagegebonden als stage-overstijgende overlegorganen ingesteld.

Per co-assistentschap is een stagecoördinator aangesteld die werkzaam is in het Academisch Ziekenhuis Maastricht en verantwoordelijk is voor de coördinatie van de co-assistentschappen die gedurende de tweede fase van de opleiding binnen zijn discipline, hetzij in het academisch ziekenhuis hetzij in een affiliatieziekenhuis plaatsvinden. De stagecoördinator is tevens voorzitter van de stageplanningsgroep. De taak van de stageplanningsgroep is de verschillende co-assistentschappen binnen een discipline op elkaar af te stemmen. De stageplanningsgroep overlegt over de inhoud, afstemming en problemen binnen een co-assistentschap en is verantwoordelijk voor de vormgeving van de stages in de betreffende discipline. Voor elke discipline is zulk een stageplanningsgroep ingesteld, bestaande uit de stagecoördinator, de klinisch onderwijscoördinator, vertegenwoordigers van affiliatieziekenhuizen waar de betreffende stage wordt gelopen, en een student. Ze komen jaarlijks tenminste één à twee keer bij elkaar om de onderwijssituatie te bespreken (Onderwijscommissie FdG Maastricht, 1984). Zowel de 
functie van de stagecoördinator als de planningsgroep is stagegebonden. Daarnaast zijn er een aantal stage-overstiigende organen en funclies gecreëerd.

Om het onderwijs in de tweede fase van de opleiding tot bujisarts te coördineren is in november 1986 een klinisch onderwijscoördinator aangesteld in de rang van hoogleraar. Deze heeft als opdracht leiding le geven aan de coördinatis, integratie en ontwik. keling van het klinisch onderwijs in de geneeskunde.

Binnen de affiliatieziekenhuizen worden verschillende coassistentschappen gelopen. Voor een goede gang van zaken is het nodig dal do diverse onderwijsactiviteiten binnen het graffilieerde ziekenhuis en de werkcontacten tussen de betrokken groeperingen worden geregeld en gecoördineerd. Daartoe is in elk affiliatie-ziekenhuis een affiliatiecoördinator aangesteld. Dit is een arts, die over een ruime klinische ervaring beschikt en bovenal het vertrouwen van de medische staf ter plaatse en van de faculteit geniet. De affiliatiecoördinator is verantwoordelijk voor het coördinerer van onderwijsactiviteiten binnen ziekenhuis en het coördineren van werkcontacten tussen de faculteit en ziekenhuis.

Daarnaast functioneert er sedert 1986 binnen elk opleidingsziekenhuis een onderwijscommissie, waarin zaken op het niveau va het afzonderlijke ziekenhuis in relatie tot de Faculteit der Geneeskunde worden bespre ken. Deze commissie bestaat uit de affiliatiecoördinator, vertegeriwoordigers van de disciplines, die coassistenten in opleiding hebben, aangevuld met enkele vertegenwoordigers van de onderwijscoördinatiecommissie van de Medische Faculteit Macstricht. Bovendien heeft de onderwijscoördinatiecommissie maatregelen genor.en om de inrichting van de co-a sistentschappen meer controleerbaar en beheersbaar te maken door het verplicht stellen van een slageboek, de opzet van een uniform beoordelingssysteem om de resultaten van studenten te beoordelen en de invoering van een systeem voor de evaluatie van de kwaliteik van de stages.

Elke planningsgroep is veiplicht voor zijn stage een stageboek samen te stellen. In het stageboek is praktische en inhoudelijke informatie opgenomen (Essed, 1987). Hierin zijn roosters vasigelegd, onderwijsbijeenkomste, vermeld evenals de gehanteerde procedure bij beoordeling en toetsing, de verantwoordelijkheden van de co-assistenten en dergelijke. Daarnaast beval het stageboek zaken die rechtstreeks op de inhoud van het co-assistentschap zijn gericht zoals een overzicht van de doelstellingen van de stage, aanbevolen literatuur, een overzicht van belangrijke patiëntproblemen en een zelftoets om het eigen kennisniveau vast t $\epsilon$ stellen. De stageboeken worden jaarlijks bijgesteld. Elk student ontvangt het stage- 
boek voordat hij/zij met het betreffende co-assistentschap begint. Door het stageboek kriigt de faculteit meer zicht op datgene wat binnen een co-assistentschap gepland is. Signalering van afwijkingen van het geplande programma is daardoor makkelijker. Bovendien geeft het stageboek de studenten inzicht in de eisen die gesteld worden.

Aan het einde van elk co-assistentschap worden de studenten beoordeeld op hun kennis en kunde. Het streven is dat de beoordeling in alle co-assistentschappen op een uniforme wijze plaatsvindt. Om hiervoor zorg te dragen is in 1988 de stagebeoordelingscommissie (SBC) ingesteld onder voorzitterschap van de klinisch onderwijscoördinator. De SBC heeft tot taak een stage-evaluatie procedure te ontwikkelen voor de stages in het vijfde en zesde studiejaar, en wel volgens de randvoorwaarden en bepalingen van het vigerend examenreglement (Essed, 1989).

Om de kwaliteit van de stages te bewaken is op verzoek van de toenmalige studierichtingscommissie en onderwijscommissie het project programma-evaluatie gevraagd om een systeem voor stageevaluatie op te zetten en te implementeren. Het project programmaevaluatie heeft tot taak gegevens te verzamelen over de kwaliteif van het onderwijs, die als basis moeten dienen om verbeteringen in stages aan te brengen. In 1987 is gestart met een jaarlijkse evaluatie van de co-assistentschappen. De evaluatierapporten bevatten een overzicht van knelpunten binnen een stage en voorzien de planningsgroepen van feedback-informatie ter behoud en verbetering van de kwaliteit van het onderwijs. De onderwijscoördinatiecommis. sie controleert of de evaluatiegegevens daadwerkelijk gebruikı worden voor de bijstelling van programma's (Wolthagen \& Essed, 1989).

Uit deze maatregelen blijkt dat binnen de Medische Faculteit Maastricht gestreefd is naar een rationalistische organisatievorm van het onderwijs, waarbij de functie van docenten duidelijk omschreven is.

\subsection{Kwaliteit van stages gemeten}

$\mathrm{Bij}$ anderzoek naar de kwaliteit van onderwijs wordt veelal een onderscheid aangebracht in metingen die zich richten op de kwaliteit van het leerproces of op de kwaliteit van de uitkomst (Stufflebeam et al., 19711. De operationalisering van begrip kwaliteit verschilt al naar gelang het betrekking heeft op het onderwijsleerproces of de vitkomst daarvan. 
Vanuit opvattingen over kwaliteit die gericht zijn op het onderwijsleerproces richt men zich op de voorwaarden waaronder leren plaatsvindt. De nadruk wordt hierbij gelegd op hel verhelderen en beschrijven van de condities die bijdragen tot een optimaal leerklimaat (Provus, 1971; Stake, 1967; Stufflebeam el al., 1971). Enerzijds kan men zich richten op interne en anderzijds op externe voorwaarden. Interne voorwaarden hebben betrekking op eigenschappen van studenten en/of leerstrategieën die het leren zouden bevorderen. Hierbij gaat men uit van een leerpsychologische invalshoek. Deze benadering vereist dat kennis beschikbaar is omtrent de wijze waarop leren verloopt. Bij externe voorwaarden doelt men op condities in de omgeving van de leerling waarvan men aanneemt dat ze leren bevorderen. Hierbij hanteert men een meer onderwijskundige invalshoek. Een voorbeeld van evaluatiebenadering die gestoeld is op de procesbenadering is hef "countance-model" van Stake (1967). Ook de "goal-free evaluation" van Scriven (1974) en het "Context, Input-, Proces- en Produktevaluatie model" van Stufflebeam e.a. (1971) vloeien voort vit deze opvatting.

$\mathrm{Bij}$ opvattingen over kwaliteit die gericht zijn op de output van het onderwijsleerproces, concentreert men zich veelal uitsluitend op het meten van de effectiviteit van het onderwijsprogramma (de Groot, 1983; van der Linden, 1992). Men richt zich op het verband tussen de vooropgezette doelen en de feitelijk bereikte doelen. Een dergeliike benadering vereist een operationalisatie van doelstellingen. De mate waarin de beoogde doelstellingen bereikt zijn, wordt binnen deze aanpak veelal bepaald aan de hand van toetsen, die als een operationalisatie van de vooropgezette doelen zijn te beschouwen. Opvattingen waarbij men de kwaliteit van onderwijs operationaliseert in termen van outputmelingen, zijn gebaseerd op het "doelstellingen denken" van Tyler [1950). Een groot aantal ontwikkelingen op het gebied van het specificeren van doelstellingen moet binnen deze traditie geplaatst worden. Bloom (1979) ontwikkelde zo een raamwerk voor het classificeren van onderwijsdoelstellingen. Ook het werk van Mager (1962) hoort in deze traditie thuis. Het zal duidelijk zijn dat deze laatste benadering van kwaliteitsmeting aantrekkelijk is voor degenen die van mening zijn dat doelstellingen de centrale plaats dienen in te nemen in het onderwijs.

Wanneer men outpulmetingen gebruikt als middel om de kwaliteit van het onderwijs te verbeteren, kleven hieraan tekortkomingen. Het nadeel van deze benadering dal er een te eenzijdige nadruk ligi op de prestaties van studenten. De leereffecten worden veelal gemelen met een roets. Bii onvoldoende toetsresultaten kunnen deze toegeschreven worden aan de kwaliteit van het meetinstrument, aan de kwaliteit van het leerproces of aan de inzet van de stu- 
denten. Men verkrijgt zo geen aanwijzingen over "wat" zou moeten veranderen omdat de bron van de problemen lastig gedetermineerd kan worden. Procesindicatoren daarentegen geven aanwijzingen over de achtergronden, het "waarom" van de opbrengsten. Hierdoor ontvangt de onderwijsgevende informatie over verschillende deelaspecten van het onderwijs waarvan men aanneemt dat deze invloed hebben op het onderwijs (Oakes, 1989). Bij deze benadering loopt men het gevaar, dat hel viteindelijk doel van onderwijs, het bewerkstelligen van leereffecten, op de achtergrond raakt.

Gezien de doelstelling die het instrument in deze studie beoogt namelijk het verschaffen van evaluatieve informatie over de kwaliteit van co-assistentschappen - is het zaak inzicht te verkriigen op de sterke en zwakke aspecten van een co-assistentschap. Een doelstellinggeoriënteerde benadering geeft nauwelijks informatie over datgene wat zou moeten veranderen en daarenboven zijn er tot op heden geen vitgeschreven doelstellingen van co-assistentschappen beschikbaar. Wel dient opgemerkt te worden dat er allerlei voorbereidingen worden getroffen om doelstellingen voor het praktisch medisch onderwijs te expliciteren (Metz, Bulte \& Paridon, 1990). Een gevalideerde outputmeting is op dit moment echter (nog) niet mogelijk. Een benadering waarbij kwaliteit gemeten wordt in termen van de "output" is in deze onderhavige studie dan ook niet ondernomen. Een benadering waarbij kwaliteit gemeten wordt in termen van het "proces" ligt meer voor de hand. Hierbij geld de volgende beperking. Er wordt niet ingegaan op allerlei interne voorwaarden, dat wil zeggen eigenschappen van sfudenten die leren bevorderen, zoals intelligentie, motivatie en dergelijke. Immers op dit moment is weinig bekend over de wijze waarop het leren tijdens co-assistentschappen verloopt. Alhoewel ook hier geldt dat er met betrekking tot co-assistentschappen een toenemende aandacht is vocr theorieen modelvorming als voor empirisch onderzoek naar leerprocessen en de invloed op leereffecten (Boshuizen, 1989). De nadruk in deze studie ligt op een onderwijskundige aanpak waarbij ingegaan wordt op externe voorwaarden, in casu op condities waarvan aangenomen wordt dat ze voorwaardenscheppend zijn voor hel goede verloop van de stage. Deze benadering is zinvol vanuit de gedachte dat structurering van stages systematisch leren bevorderd (de Bie, 1989). Voorts wordt inzicht verkregen in aspecten van de leeromgeving die veranderbaar en ook manipuleerbaar zijn. Bijvoorbeeld wanneer blijkt dat studenten op de polikliniek niet over een ruimte beschikken waar ze zelfstandig patiënten kunnen onderzoeken, dan is mogelijk om hierin verandering te brengen of wanneer de begeleiding van studenten slecht georganiseerd is, kan in een dergelijke situatie verbetering aangebracht worden door hierover afspraken te maken. 
Concluderend kan gesteld worden dat in .eze studie de meting van de kwaliteit van co-assistentschappen gericht is op de voorwaarden waaraan een co-assistentschap naar onderwijskundige maatstaven zou moeten voldoen. Een volgende stap is om aan te geven welke deze voorwaarden zijn. Hierop wordt in hoofdstuk 5 nader ingegaan.

\subsection{Samenvatting}

In dit hoofdstuk is beschreven dat een onderwijsorganisatie aan een aantal kenmerken moet voldoen, wil een gestandaardiseerde programmaevaluatie mogelijk zijn. Typering van de organisatie vindi plaats aan de hand van een omschrijving van het organisatieklimaat en de opvaltingen over de rol van docenten. De Faculteit der Geneeskunde van de Rijksuniversiteir Limburg kent een rationalistisch organisatieklimaat waarbij de rollen en functies van docenten omschreven zijn. Hierdoor is een klimaat ontstaan, waarbinnen een gestandaardiseerde evaluatie van stageprogramma's tot de mogelijkheden behoort. Vervolgens is aangegeven dat evaluatie kan gebeuren vanuit de produktgerichte benadering of de procesgerichte benadering. Beargumenteerd is waarom deze evaluatiestudie uitgaat van de procesbenadering. Deze meting van de kwaliteit van klinisch onderwijs richt zich op de voorwaarden waaraan een coassistentschap naar onderwijskundige maatstaven moet voldoen. 


\section{Constructie van het meetinstrument}

In het voorgaande hoofdstuk is aangegeven dat de setting binnen de Faculteil der Geneeskınde van de Rijksuniversiteit Limburg geschikt is voor de invoering van een gestandaardiseerde evaluatie van klinische co-assistentschappen. Kwaliteit van klinisch onderwijs wordt in deze studie opgevat als de voorwaarden waaraan co-assistentschappen in ziekenhuizen naar onderwijskundige maatstaven zouden moeten voldoen. De volgende stap is de constructie van een instrument om de kwaliteit van stages te meten. Het constructieproces bestaat uit vier stappen. De eerste stap is het identificeren van de voorwaarden waaraan een stage moet voldoen. De tweede stap betreft het kiezen van een geschikte evaluatievorm. De derde stap bestaat uit een try-out van het instrument op kleine schaal en de vierde stap uit de vaststelling van het instrument. In paragraaf 5.1 tot en met 5.4 worden deze stappen achlereenvolgens besproken. In paragraat 5.5 volgt een samenvalting.

\subsection{Omschrijving van voorwaarden}

De inrichting van stages was lange tijd vitsluitend een aangelegenheid van het bedriff c.q. instelling waar stage werd gelopen. De opleiding bemoeide zich nauwelijks met de inhoud en vormgeving van dit onderwijs. De laatste jaren is er vanuit opleidingen, met name binnen het beroepsonderwijs, een toenemende belangstelling te constateren voor de inrichting van stages. De reden hiervan is dat de opvalting terrein wint, dat stages een leermiddel zijn om bepaalde opleidingsdoelen te realiseren. De stage gaat daardoor een wezenlijk onderdeel vitmaken van het totale opleidingsprogramma. Dit leidt tot een schoolgerichte benadering van stageplaatsen of wel het "pedagogiseren van de stageplaatsen" (van den Dool, 1987; de Vries, 1988]. Als gevolg van deze ontwikkeling gaan opleidingen zich meer bezinnen op de functie van stages.

Er wordt een onderscheid gemaakt lussen oriënterende stages en beroepsopleidende stages. Bij oriënterende stages is het doel om de student op globale wijze kennis te laten maken met het beroeps- 
veld. Het befreft veelal korte stages van enkele dagen of een week. De beroepsopleidende stages zijn een directe voorbereiding op het beroep (de Jong, 1982; Mertens, 1981). Vanuit deze functies worden verschillende eisen gesteld aan de inrichting van de stage. De betrokkenheid en inbreng vanuit de opleiding voor stages neemt hierdoor toe, waardoor de kwaliteit van stages een directe aangelegenheid wordt van de opleidingen. Binnen het beroepsonderwijs hebben talrijke experimenten plaatsgevonden die zich richten op de verbetering van de inrichting van stages, bijvoorbeeld door het ontwerpen van stagemodellen. Bekend zijn het studiestagemodel voor de opleiding lot onderwijsgevenden (de Jong et al., 1984), en diverse modellen voor leren in arbeidssituaties (de Bruijn, 1985; van Zwieten, 1985).

Binnen het medisch onderwijs is aanmerkelijk minder aandacht gegeven aan een op onderwijskundig gestoelde inrichting van stages (Scherpbier \& Metz, 1989). In Nederland is in dit kader onderzoek verricht door Van Rossum (1977) en Bouhuijs (1983). Van Rossum heeft onderzoek gedaan naar de inrichting van de stage gynaecologie/verloskunde, terwijl Bouhuijs de stage huisartsgeneeskunde binnen de opleiding tot basisarts tot object van studie heeft gemaakt.

De Vries (1988) concludeert op basis van studies dat bij stages in plaats van de principes van de schoolse didactiek de principes van "training on the job" gelden. Hieronder verstaat hij een georganiseerd leerproces op de werkplaats dat aan zekere voorwaarden voldoet en zich van niet-georganiseerde leerprocessen onderscheid met name door de expliciete aanwijzingen van de begeleider. Hieruit volgt dat de situatie op de stageplaats aan bepaalde eisen moet voldoen. Klinische stages zijn in termen van De Vries te definiëren als een beroepsopleidende stage waarbij "training on the job" plaatsvindt. Om te komen tot een set van eisen waaraan een effectieve stage moet voldoen, heeft De Vries een uitgebreide inventarisatie gemaakt van onderzoeken die gericht zijn op het opsporen van factoren die van invloed zijn op leren. Hij maakr een onderscheid in drie relevante groepen factoren. De eerste groep heeft betrekking op kenmerken van het onderwijs in relatie tot de stages. Onderwiiskenmerken omvatten zowel die van het normale binnenschoolse onderwijs van een school als die van activiteiten van een school ten behoeve van een onderwijsvorm met een buitenschoolse leerplaats. Kenmerken van het onderwijs hebben enerzijds betrekking op de wijze van structurering van de stages, dat wil zeggen hel aantal stages, de duur per stage, het stagemodel, en anderzijds op de wijze en mare van sturing, dat wil zeggen op de door de opleiding gepleegde interventies ten behoeve van het leerproces 
tijdens de stage. Tot de tweede groep behoren stageplaatskenmerken, door De Vries onderscheiden naar de inhoud van het werk van stagiaires, de omstandigheden en voorwaarden waaronder zii werken en de begeleiding die zij krijgen. Tot de derde groep behoren leerlingkenmerken. Hieronder verstaat hij eigenschappen van leerlingen zoals de beginsituatie, de motivatie voor het stagewerk en de capaciteit van studenten om in ongestructureerde situaties te leren.

Onderzoeken waarin onderzocht wordt welke factoren van invloed zijn op de leereffecten, gaan veelal uit van studentwaarnemingen. Studenten geven aan wat in hun perceptie belangrijke factoren zijn die bijdragen tot leren. Relatie met de feitelijke leerresultaten ontbreken op dit moment nog. Het blijkt dat van genoemde drie groepen kenmerken van de stageplaats doorslaggevend zijn. Kenmerken van het onderwijs zijn van minder belang dan aanvankelijk verondersteld werd. Deze conclusie wordt door veel onderzoeken bevestigd. Uit een studie van Owens en Owen (geciteerd in van den Dool, 1987) blijkt bijvoorbeeld dat aspecten die te maken hebben met de inhoud van het werk, de uitvoering en de begeleiding van belang zijn. Studenten geven aan dat ze het meest leren als ze actief betrokken worden bij de vitvoering van het werk, en het takenpakket representatief is voor het werk op de stageplaats. Hieruit volgt dat leerinhouden die beroepsspecifiek zijn door studenten als zeer leerzaam worden ervaren. Ze moeten gelegenheid krijgen om zelfstandig te werken, voldoende verantwoordelijkheden krijgen, zich nuttig voelen en de taken moeten uitdagend zijn. De beste leerervaringen worden opgedaan in plaatsen waar een positieve relatie met opleider bestaat en waar de leerlingen een directe begeleider hebben.

Uit onderzoek van Leske en Persico (1984) komt naar voren dat leerlingen een stage effectiever vinden als het werk op de stageplaats een realistische afspiegeling is van het werk waarop zij voorbereid worden. Meijer en Lucassen (1985) concluderen dat voor de realisatie van leereffecten een combinatie van stageplaars- en stagiaire- kenmerken het belangrijkste is. Onderwijskenmerken worden als minder belangriik beschouwd. Een adequate voorbereiding van de stagiaire op de stage blijkt echter wel van invloed te zijn op de leereffecten. De motivatie van de stagiair om het betreffende stagewerk te willen leren, de intensiteit van begeleiding, de kwaliteit van het werk en, zij het in mindere mate, betrokkenheid bij het bedriif blijken van grote invloed te zijn op het leereffect. Tenslotte blijkt het belangrijk te zijn dat een stagiair in staat is om in ongestructureerde situaties te leren, hetgeen ondermeer tot uiting komt in het stellen van vragen, hel zelfstandig zoeken naar oplossingen voor problemen. 
Op basis van onderzoeken binnen het beroepsonderwijs kan geconcludeerd worden dat de volgende elementen door studenten als belangriik voor een effectieve stage gezien worden:

de voorbereiding op hel werk;

de helderheid van informatie over de situatie op

de stageplaats;

de inhoud van het werk;

het takenpakket;

de kwaliteit van het werk;

het realiteitsgehalte van het werk;

de uitvoering van het werk;

de omstandigheden van het werk;

de mate van zelfstandigheid;

de mate van afwisseling;

de intensiviteit van begeleiding.

De begeleiding op de werkplaats wordt unaniem als één van de meest belangrijke voorwaarden gezien voor een effectieve leeromgeving. Het is dan ook niet verwonderlijk dat veel studies zich expliciet richten op de kenmerken waaraan begeleiders zouden moeten voldoen.

Amerikaanse studies naar de inrichting van klinische settings richten zich veelal uitsluitend op effectieve gedragingen van docenten. Miller (1961) concludeert op basis van onderzoek naar docentgedrag van klinici, dat effectief docentgedrag zich kenmerkt door geduldig zijn, het stellen van probleemoplossende vragen, het geven van samenvaltingen en het aanmoedigen van kritisch denken. Coombs en Boyle (1971) hebben onderzoek gedaan naar effectief docentgedrag van artsen. Uit hun onderzoek blijkt dat de belangrijkste variabelen voor effectief docentgedrag zijn: enthousiasme, interesse in studenten, goede organisatie van voordrachten en relevante leerstof overbrengen. Byrne en Cohen (1973) hebben op basis van een onderzoek naar onderwijsactiviteiten in twee "teaching hospitals" van de universiteit in Toronto een overzicht samengesteld van leeractiviteiten die door studenten tijdens de stages werden ondernomen. Zij onderscheiden tien leervormen: variërend van passieve tot actieve leervormen. In het onderzoek werd eveneens nagegaan welke leervormen door studenten tijdens een stage geprefereerd worden. De resultaten wijzen uit dat actieve leervormen het meest geprefereerd werden en de passieve leervormen het minst. Stritter et al. (1975) hebben een poging gedaan om de gedragingen van meest effectief klinisch onderwijsgedrag op le sporen. Doel van hun onderzoek was om de gedragingen van docenten op te sporen die volgens studenten faciliterend zijn voor effectief leren. Hel onderzoek vond plaats bij 265 medische studenten in het derde en vierde 
jaar van de universiteit van North Carolina en de universiteit van Alabama. De studenten kregen een vragenlijst voorgelegd met 77 items. De items hadden betrekking op de gedragingen van docenten, de interactie docent-student, de klinische instructie en andere aspecten, niet betrekking hebbend op de vakinhoud. Voorts waren er een aantal items toegevoegd betrekking hebbend op zaken waarvan verondersteld werd dat deze niet van invloed zouden zijn op effectief docentgedrag. Van elk van die items moest op een vijfpuntsschaal worden aangegeven in welke mate het bijdroeg aan effectief leren. Op basis hiervan geven Stritter el al. (1975) een overzicht van factoren. Het is belangrijk dat docenten aan studenten een actieve rol toekennen door bijvoorbeeld studenten vaardigheden te laten demonstreren en hen te betrekken bij het oplossen van problemen. De positieve opstelling van de docent naar de student is zeer belangrijk in termen van interesse tonen, vriendelijkheid, enthousiasme, dynamiek en energie. Positief is als de docent de student geregeld informeert over zijn voortgang. Daarnaast dient de opleider in de ogen van de student deskundig op zijn vakgebied te zijn. Opgemerkt dient te worden dat er geen relaties tussen effectief docentgedrag en studieresultaten zijn onderzocht. Mattern, Weinholtz en Friedman (1983) hebben getracht via observatie een aantal strategieën te achterhalen die karakteristiek zijn voor effectieve klinische instructie. Het onderzoek is uitgevoerd gedurende in 1980 aan the Department of medicine van de universiteit of North Carolina at Chapel Hill en in het North Carolina Hospital. Zes medische afdelingsteams werden a-select geselecteerd. Deze teams werden gedurende 62 afdelingsronden en een aantal andere instructie-activiteiten geobserveerd. Voorts werden 57 interviews gehouden met teamleden. Mattern et al. (1983) concluderen dat het mogelijk is "good clinical teaching" te expliciteren en te evalueren, ook in complexe situaties van afdelingsvisites van een ziekenhuis. Uit de gegevens blijkt dat belangrijk is dat docenten tijd vrij maken voor de student, een klimaat van vertrouwen creëren, goed luisteren, vragen stellen en indrukken van studenten als aanleiding gebruiken voor verdere discussie en analyse en dat de docent oog heeft voor de psychosociale aspecten in de patiëntenzorg. Irby $(1978,1981,1983)$ heeft talrijke studies verricht naar de kenmerken van effectief docentgedrag in medische settings. Hij identificeert zeven factoren die bijdragen tot effectief docentgedrag: het verzorgen van heldere voordrachren, enthousiasme en een stimulerende houding, de vaardigheid om problemen te analyseren, didactische vaardigheden om groepsonderwijs te verzorgen en supervisie te geven, het beschikken over voldoende kennis, het vervullen van een voorbeeldfunctie voor studenten. Rothman, Poldre en Cohen (1989) exploreerden de 
didactische kwaliteit van dacenten. Om uitspraken te doen over de kwaliteit van onderwijs moeten naar hun mening echter meer gegevens verzameld worden. Naast informatie over de docent, verzame len zij gegevens over alle onderwijsactiviteiten en verrichtingen van studenten die zijn vitgevoerd tijdens de stage. Zij laten het gedrag van de artsbegeleiders beoordelen door studenten en collega-begeleiders. Hierbij wordt aandacht besteed aan attitude van de arts, organisatie, voorbereiding, bereidheid tot helpen, het geven van constructieve kritiek, het geven van feedback, problemen vanuit verschillende oprieken bekijken, bevorderen van kritisch denken, rolmodeling en het algemeen oordeel van de student over de stage. Van alle docenten wordt een archief bijgehouden waarin informatie is opgenomen inzake hun begeleidingsvaardigheden. Gedurende elke stage wordt een overzicht gemaakt van onderwijsactiviteiten die hebben plaatsgevonden. Studenten wordt gevraagd aan de hand van gestruclureerde lijsten een oordeel over alle onderwijsactiviteiten (zoals lezingen en patiëntprestentaties) gevraagd. Daarnaast laten zij studenten een overzicht geven van de verrichtingen die zij hebben uitgevoerd tijdens de stage. Ook komt aan de orde hoe vaak deze door opleiders gedemonstreerd zijn en hoe vaak de studenten door opleiders geobserveerd zijn.

Al deze studies benadrukken het belang van een goede begeleiding op de stageplaats. De concrete invulling van de begeleiding kan verschillen. Essentieel is echter dat de begeleider een positieve houding heeft tegenover de begeleiding en werkelijk belangstelling toont voor de individuele studenten. De begeleiding moet zich richten op technische handelingen maar ook op aspecten die te maken hebben met de patiënt en de omgeving.

Naast empirisch onderzoek zijn ook, meer normatieve maatregelen geformuleerd die door een onderwijsinstelling getroffen moeten worden om een stage succesvol te laten verlopen. Een overzicht van formele voorwaarden voor stages is ondermeer gemaakt door Snoek (1980). Hij stelt dat er in ieder geval een stagecontract opgesteld moet worden, doelstellingen geformuleerd moeten worden, een stagementor, een stagebegeleider en een stagecoördinator aangesteld moeten worden met duidelijk omschreven taken en verantwoordelijkheden. Daarnaast moet er een adequate voorbereiding op de stage plaatsvinden, integratie tussen binnen- en buitenschoolse activiteiten, een evaluatie van de stage en een beoordeling van de stagiair. Voorts zijn er talrijke interne rapporten van opleidingen waarin de instellingen zelf aangeven welke eisen zij stellen aan de stagebiedende instanties, welke maatregelen de opleiding treft om de stage zo goed mogelijk te laten verlopen en welke eisen aan studenten gesteld worden. 
Bij de constructie van de vragenlijst voor de beoordeling van de kwaliteit van stages die in dit proefschrift beschreven wordt, is zoveel mogelijk met deze elementen rekening gehouden. Het lijkt gerechtvaardigd om bij de definiëring van voorwaarden waaraan stages zouden moeten voldoen uil te gaan van de kenmerken van de stageplaats. Het merendeel van de besproken studies heeft de volgende aspecten gemeenschappelijk.

1. De stage dient aan te sluiten op de voorkennis van de student (Meijer \& Lucassen, 1985).

Aansluiting bij de vooropleiding van de student is van belang omdat anders van veel nieuwe informatie de betekenis zou ontgaan. Er dient voortgebouwd te worden op reeds beschikbare kennis en verworven vaardigheden. Over het geheel genomen blijkt dat stageresultaten positiever zijn naarmate de studenten beter voorbereid zijn op de stage voor wat betreft kennis en vaardigheden.

2. De studenten dienen intensief begeleid te worden door de artsen op de stageplaats.

Uit onderzoek (Irby, 1981, 1983; Mattern et al., 1983; Rothman et al., 1989) is bekend dat een adequate begeleiding de leerzaamheid bevordert. Binnen beroepsonderwijs en binnen klinisch onderwijs is veel aandacht besteed aan de vormgeving van de begeleiding. De begeleiding moel zich op velerlei aspecten richten. Enerzijds zal de begeleiding zich in sterke mate moeten richten op het persoonlijk functioneren van de student in relatie tot de stagewerkzaamheden. Anderzijds zal de begeleiding een op hel werk gericht karakter moeten hebben met aandacht voor medisch-technische vaardigheden en aspecten die verband houden met de patiënt en zijn omgeving.

3. Studenten dienen duidelijk geïformeerd te worden over datgene wat hun te wachten staat gedurende de stage (de Vries, 1988).

Heldere informatie over wat studenten kunnen verwachten op verschillende terreinen, is bevorderlijk voor een efficiënt verloop van de stage. Dit betekent dat de studenten geinformeerd moeten worden over de doelstellingen van de stage, de werkzaamheden die verwacht worden en de wijze waarop de beoordeling plaatsvindt. Voorts is het belangrijk dat studenten op de hoogte zijn van organisatorische en praktische zaken zoals roosters, de namen van de begeleiders, relevante literatuur etc. 
4. Studenten dienen aanwezig te zijn bij besprekingen over patiënten (Bouhuijs, 1983; van Ros um, 1977).

$\mathrm{Bij}$ ue behandeling van patiënten worden specialisten uit diverse disciplines betrok! on. In dit kader zullen er regelmatig overlegsituaties tussen artsen plaatsvinden. Het is belangrijk dat de student hiervan kennis neemt door bij zoveel mogelijk besprekingen aanwezig te zijn zoals patiëntbesprekingen, pathologie-besprekingen en röntgenbesprekingen.

5. Studenten dienen op verschillende lokaties te verblijven binnen een stage (van Rossum 1977).

Een stage dient onderscheiden doch samenhangende leermomenten te bevatten en studenten moeten participeren in de werkzaamheden op verschillende afdelingen. In klinische stages betekent dit dat de student aanwezig zal moeten zijn op de operatiekamer, de verloskamer, de polikliniek, de verpleegafdeling.

6. Studenten dienen de beschikking te hebben over voldoende faciliteiten.

Wanneer studenten bij hun werkzaamheden in de patiëntenzorg op problemen stuiten moeten ze in de gelegenheid zijn om zaken na te zoeken en/of te bestuderen. Hiervoor is het noodzakelijk dat er de nodige leermiddelen in de vorm van boeken, tijdschriften, naslagwerken en/of audio-visueel materiaal aanwezig zijn. Tevens dient er een ruimte te zijn waar ze ongestoord kunnen studeren.

7. De student moet voldoende tijd doorbrengen op de stageplaats en voldoende tijd besteden aan studieactiviteiten (Bouhuijs, 1983).

De sludent dient voldoende tijd te besteden aan de stage. Het aantal niet-leerzame momenten zoals "routine klussen" of het bijhouden van de administratie, het halen van statussen dient duidelijk ondergeschikt te zijn aan het aantal leerzame momenten.

8. De student moet zelfstandig kunnen werken (Meijer \& Lucassen, 1985).

Een groot deel van de werkzaamheden zal plaatsvinden op de polikliniek. Met name op deze plaats zal de student de intake van nieuwe patiënten verrichten. Het is daarom belangrijk dat er zowel in de polikliniek als op de af- deling een geschikte ruimte is waar de student in de gelegenheid wordt gesteld zelfstandig een patiënt te onderzoeken.

9. Leren dient primair plaats te vinden aan de hand van "levensechte" patiëntproblemen (Leske \& Persico, 1984).

De stage-situatie dient een afspiegeling te zijn van de sifuatie 
waarvoor studenten opgeleid worden. Een belangrijke "meerwaarde" van praktijkstages is dat de student in contact komt met echte patiënten. Dit in tegenstelling tot de eerste vier jaar van de opleiding, waarin de student vaardighed en heeft geoefend op fantomen en simulatiepatiënten. Tijdens de stage moet de student met voldoende patiënten in aanraking komen. Daarnaast is het zaak dat de student met diverse soorten patiëntproblemen geconfronteerd wordt, omdat hierdoor zicht wordt verkregen op vakgebied en verschillende vaardigheden geoefend kunnen worden.

10. Een stage moet gekenmerkt worden door een heldere afsluiting in de vorm van een stagebeoordeling, die adequaat besproken wordt mei de student (van den Dool, 1987). Aan het einde van elke stage vindt een beoordeling plaats. Deze beoordeling heeft betrekking op het functioneren tijdens de stage en op de beschikbare kennis van de student over het betreffende vakgebied. De beoordeling moet plaatsvinden op de afgesproken tijd en op basis van duidelijk geformuleerde criteria. Elke beoordeling dient grondig met betrokkene doorgesproken te $v$ orden, opdat de student hiermee ook zijn voordeel kan doen voor de volgende stages.

11. De student moet in de gelegenheid zijn om binnen de stageperiode te studeren c.q. te oefenen op vaardigheden (Bouhuijs, 1983).

De student heeft gedurende de eerste vier studiejaren kennis en praktische vaardigheden verworven. Gedurende de stage worden deze in praktiik gebracht. De student zal naar aanleiding van ervaringen in de praktiik bepaalde tekorten in zijn kennis en vaardigheden opmerken. Daarom moet gelegenheid gegeven worden om zelfstandig zijn leemtes weg te werken.

12. Voor studenten dienen speciale onderwijsbijeenkomsten plaats te vinden (Bouhuijs, 1983; van Rossum, 1977).

De stage is een onderwijsleersituatie, waarbii patiëntcontacten een belangrijke leerbron zijn. Dit impliceert dat de stage voldoende momenten dient te bevalten waar de studenten ook daadwerkeliik iets leren en die een educatieve waarde hebben. Enerzijds zullen dit formele leermomenten zijn, bijvoorbeeld bijeenkomsten die georganiseerd zijn voor studenten en qua inhoud expliciet afgestemd ziin op deze doelgroep. Anderzijds zullen er veel informele leermomenten zijn, dat wil zeggen activiteiten waarvan het leereffect hoog is maar die niet expliciet georganiseerd zijn voor studenten.

13. In ziin algemeenheid kan gesteld worden dat de leeromgeving gekenmerkt moet zijn door een goede werksfeer, een 
doorzichtige onderwijsorganisatie en een leerzame omgeving.

Het effect van een stage zal toenemen wanneer een co-assistentschap gekenmerkt wordt door een goede werksfeer is, een duidelijke organisatie en veel leerzame momenten.

\subsection{Evaluatievorm}

In de vorige paragraaf is aangegeven aan welke kenmerken een coassistentschap moet voldoen. Door deze aspecten meetbaar te maken, krijgt men zicht in welke mate hieraan is voldaan. Dergelijke informatie vormt de basis om uitspraken te doen over de kwaliteit van stages zodal gericht aan verbetering van de stage gewerkt kan worden. De volgende stap is de constructie van een instrument voor stage-evaluatie.

Bij evaluatie van onderwijsprogramma's gebruikt men diverse typen instrumenten. Enerzijds instrumenten gericht op het verzamelen van meer kwalitatieve informatie, bijvoorbeeld door middel van "learner reports" of interviews, en anderzijds door instrumenten die zich richten op het verzamelen van meer kwantitatieve informatie zoals gestructureerde vragenlijsten (van Os, 1987). Professioneel opgezette systemen voor onderwijsevaluatie maken meestal gebruik van vragenlijsten. Voorbeelden van evaluatiepakketten zijn: Docent en Onderwijs Evaluatiesysteem (DOE) van het Instituut voor Onderzoek van het Wetenschappelijk onderwijs, Onderwijsverbetering op basis van Studentoordelen (OSO) van de Erasmus Universiteit Rotterdam, Universiteit van Amsterdam onderwijsevaluatie pakket (UVALON). Hef instrumentarium voor de Systematische Evaluatie van Kursussen" (ISEK-procedure) maakt zowel gebruik van schriftelijke vragenlijisten als interviews (zie van Os, 1987). Vragenlijsten hebben als voordeel dat het mogeliik is om in relatief korte tijd bij een grote groep respondenten informatie te verzamelen. Voorts is de afname organisatorisch makkelijk te verwezenlijken en kan de verwerking op een geautomatiseerde en gestandaardiseerde wijze plaatsvinden. De interpretatie gebeurt aan de hand van vooraf geformuleerde richtlijnen.

Op basis van ervaringen elders is besloten om voor de evaluatie van co-assistentschappen eveneens een schriftelijke vragenlijst te construeren. Aspecten waarvan aangenomen wordt dat ze kenmerkend zijn voor effectieve stages, dienen daartoe geoperationaliseerd te worden in items. Daaraan voorafgaande moet de respondentgroep, de vraagvorm en de meetschaal vastgesteld worden. 


\section{Informatiebronnen}

Er zijn in principe meerdere informatiebronnen mogelijk die inzicht kunnen geven in de kwaliteit van een co-assistentschap. Men kan artsbegeleiders, studenten of bestuurders om hun mening vragen of externe deskundigen inhuren om het onderwijs te inspecteren. Artsbegeleiders en studenten hebben als voordeel dat ze beiden als "directe" participanten van het onderwijs beschouwd kunnen worden en dus feitelijk actoren, getuigen, zijn van het leren in de stage. Bestuurders van een faculteit zijn op een afstand betrokken bij het onderwijs en zijn afhankelijk van de informatie die zij veelal van derden ontvangen. Hetzelfde geldt voor externe deskundigen, zoals visitatiecommissies. Ook zij zullen veelal afhankelijk zijn van informatie die zij van anderen ontvangen. De voorkeur gaat daarom uit naxr een respondentgroep die op basis van eigen ervaringen een uitspraak kan doen over de mate waarin aan de geformuleerde aspecten voldaan wordt. In principe zijn hiervoor de studenten en de begeleiders het meest aangewezen. Er is weinig onderzoek bekend waarin op grote schaal gebruik gemaakt wordt van oordelen van docenten om de kwaliteit van onderwijs te beoordelen. $\mathrm{Er}$ zijn daarentegen talrijke onderzoeken waarbij studenten als respondentgroep worden gebruikt om een oordeel te geven over de kwaliteit van de onderwijs. Uit onderzoek verricht door Gijselaers (1988), Marsh (1984) en Stillman (1983) blijkt dat studentoordelen een betrouwbaar beeld kunnen geven van de kwaliteil van onder. wijs en dat de studenten als ontvanger van onderwijs zeer wel in staat zijn het onderwijs op zijn merites te beoordelen.

Gezien de directheid van betrokkenheid en de ervaring die opgedaan is met studenten als informatiebron is hier gekozen voor studentoordelen als basis voor kwaliteitsuitspraken.

\section{Meetschaal}

Vervolgens is een keuze gemaakt voor de meetschaal. Door middel van een schaal worden kwalitatieve karakteristieken vitgedrukt in kwantitatieve eenheden. Bif de keuze hiervan is gebruik gemaak van onderzoek dat verricht is door Albanese et al. (1991), Berk (1979), Cohen (1981), Gijselaers (1988) en Marsh (1984). Uit deze studies blijkt dat het werken met stellingen die voorzien zijn van een Likert-schaal betrouwbare informatie geeft. Op basis van een studie van Lissitz (1975) naar schaalpunten kan geconcludeerd worden dat een vijfpuntsschaal het meest effectief is en de grootste bruikbaarheid heeft in termen van constructie en interpreteerbaarheid (Berk, 1979). Het blijkt dat een toename van het aantal schaalpunten vergezeld gaat met een toename van schaalbetrouwbaarheid. Echter de betrouwbaarheid stijgt niel meer vanaf vijf schaal- 
punten. Hieruit volgt dat maximalisering van het aantal schaalpunfen op statistische gronden niel nodig is. Daarom is gekozen voor een vragenlijst bestaande vit een aantal stellingen die voorzien zijn van een vijfpunts-Likert-schaal. De studenten geven op een schaal lopend van één tot vijf aan of zij het met een bepaalde stelling volledig oneens (1), tamelijk oneens (2), neutraal (3), tamelijk eens (4), volledig eens (5) zijn (Gijselaers, 1988; Swanborn, 1988).

Met in achtneming van deze afwegingen werd een schriftelijke vragenlijst geconstrueerd. De vragen werden zoveel mogelijk geformuleerd in stellingen, voorzien van een vijfpuntsschaal. Voorts werd er een vraag opgenomen waar studenten een algemene waardering voor de stage konden geven in de vorm van een schoolcijfer. In de vragenlijst was verder ruimte gereserveerd voor op- en aanmerkingen op de stage, die in de vragenlijst niet expliciet aan de orde werden gesteld. Bij elk aspect werden een of meerdere items geformuleerd. Hierbij werd erop gelet dat de items zo concreet mogelijk geformuleerd werden en relevant waren voor alle co-assistentschappen.

Voorts werd erop toegezien dat de items aspecten van het onderwijs betroffen waarop docenten in principe invloed kunnen vitoefenen.

\subsection{Pilotstudie}

Om inzicht te kriigen in de praktische bruikbaarheid van het instrument en zicht te krijgen op de helderheid van de geformuleerde vragen, werd de vragenlijst gefaseerd ingevoerd. Alvorens het instrument op grote schaal te implementeren, werd het instrument ter tryout gebruikt bij de co-assistentschappen gynaecologie/obstetrie en kindergeneeskunde. Met de coördinatoren van deze co-assistentschappen bestond reeds een intensieve samenwerking tijdens de constructie van het instrument en zij voelden zich sterk betrokken bij het invoering van het evaluatie-instrument. Gedurende een proefronde van zes maanden werd de lijst in 1986 bij deze twee co-assistentschappen afgenomen. De ervaringen die met de proefronde werden opgedaan waren viterst posilief. De coördinatoren vonden de resultaten goed interpreteerbaar en bruikbaar voor de verbetering van de stage. In september 1987 werd de evaluatielijst bij zes van de acht co-assistentschappen ingevoerd. Na een jaar van gebruik werd de vragenlijst in 1988 wederom voorgelegd aan de roenmalige stagecoördinatoren met het verzoek de items nogmaals te bekijken op relevantie voor hun co-assistentschap en desgewenst items toe te voegen. Ook werd door studenten commentaar geleverd, dit gebeurde zowel op individuele basis als via de studentenorganisatie voor co-assistenten. Dit heeft geleid tot marginale aanpassingen. 


\subsection{Beschrijving van het instrument}

De vragenlijst bestaat uit een uniform deel voor alle co-assistentschappen met daarnaast een specifiek deel. In het stage-specifieke deel per co-assistentschap komen aspecten aan de orde die uniek en belangriik zijn voor een bepaald co-assistentschap. Tijdens het co-assistentschap gynaecologie/obstetrie speelt bijvoorbeeld het verblijf op de verloskamer een belangrijke rol; tijdens hel co-assistentschap neurologie de neurochirurgische besprekingen en de overdrachisbesprekingen. In stages waar röntgenbesprekingen of pathologie-besprekingen van bijzonder belang zijn, worden hierover vragen gesteld. De lijst bevat 53 algemene vragen en 7 specifieke vragen. De vragenlijst is onderverdeeld in clusters van vragen. In deze studie spreken we steeds van domeinen. Het betreft de volgende domeinen:

1. de voorbereiding van de studenten op de stage inzake kennis en vaardigheden;

2. de informatie die studenten ontvangen over de inhoud en opzet van de stage in de vorm van een stageboek;

3. de persoonsgebonden begeleiding die studenten ontvangen met betrekking tot hun stagewerkzaamheden;

4. de begeleiding die de student ontrangt bij het medisch-technisch handelen;

5. de aandacht die tijdens de stage gegeven wordt aan zaken die niet patintgebonden zijn, maar betrekking heeft op alle aspecten die te maken hebben met de patiënt en zijn context;

6. de kwaliteit van onderwijsactiviteiten, die speciaal georganiseerd worden en qua inhoud expliciel ziin afgestemd op studenten;

7. het aanbod van patiëntproblemen met betrekking tot het aantal en het soort patiëntproblemen waarmee de studenten in aanraking komen;

8. de kwaliteit van patiëntgebonden leersituaties die plaatsvinden in een stage, zoals verbliif op de afdeling, het meelopen met visites, pathologie-besprekingen en röntgenbesprekingen;

9. de kwaliteit van de polikliniek wat betreft de beschikbare ruimte om zelfstandig patiënten te kunnen onderzoeken en de leerzaamheid;

10. de kwaliteit van studiefaciliteiten die beschikbaar zijn tijdens de stage, zoals ruimlelijke voorzieningen en leermiddelen;

11. de kwaliteit van stagebeoordeling die studenten aan het einde van een stageperiode ontvangen van de opleider;

12. de gelegenheid tot zelfstudie die aan studenten gegeven 
wordt om naar aanleiding van praktijkervaringen zelfstudie te verrichten;

13. het algemeen oordeel van de student over de stage ten aanzien van de sfeer, de organisatie en de leerzaamheid;

14. de tijdsbesteding tijdens de stage.

De analyses die beschreven worden in de volgende hoofdstukken zijn gebaseerd op de versie van 1989. In het hierna volgende is een overzicht opgenomen van de items. Voor een volledige vragenlijst wordl verwezen naar bijlage 1 .

1. Voorbereiding op de stage

volledig volledig oneens eens

- Over het geheel genomen was ik op de benodigde vaardigheden voldoende voorbereid.

- Over het geheel genomen was ik qua theoretische kennis voldoende voorbereid.

2. Informatie over de stage (Stageboek)

- Uit het stageboek werd duidelijk welke kennis en vaardigheden aan het begin van de stage verwacht werden. $\quad \begin{array}{lllll}1 & 2 & 3 & 4 & 5\end{array}$

- Het stageboek gaf een duidelijk overzicht van de patiëntproblemen die van belang waren.

- Uit het stageboek werd duidelijk op welke wijze de rol van co-assistent ingevuld zou worden (welke mate van verantwoordelijkheid, werkzaamheden e.d.).

- Het stageboek verschafte duidelijke informatie over de kennis, vaardigheden, attitude en medisch denken en handelen die aan het einde van de stage verwacht werden.

- Het stageboek verschafte een duidelijk overzicht over de wijze van beoordeling. 
3. Persoonsgebonden begeleiding

- Ik werd voldoende geintroduceerd op de stageplaats.

Ik had een duidelijk takenpakket.

volledig volledig

oneens eens

- Het was mij duideliik wie mijn begeleider(s) was (waren).

- De begeleider(s) was (waren) op de hoogte van de uitgangspunten van het Maastrichtse onderwijssysteem.

- De begeleider(s) was (waren) op de hoogte van de stagedoelen.

Ik vond de begeleiding van voldoende kwaliteit.

- Ik ben tevreden over frequentie en duur van de begeleiding.

$\begin{array}{lllll}1 & 2 & 3 & 4 & 5 \\ 1 & 2 & 3 & 4 & 5\end{array}$

$\begin{array}{lllll}1 & 2 & 3 & 4 & 5\end{array}$

$\begin{array}{lllll}1 & 2 & 3 & 4 & 5\end{array}$

$\begin{array}{lllll}1 & 2 & 3 & 4 & 5\end{array}$

$\begin{array}{lllll}1 & 2 & 3 & 4 & 5\end{array}$

$\begin{array}{lllll}1 & 2 & 3 & 4 & 5\end{array}$

4. Begeleiding bij medisch-technisch handelen

- De begeleiders(s) demonstreerde(n) mii in voldoende mate een aantal vaardigheden met de bedoeling om mijn vaardigheden te optimaliseren.

- Ik kreeg nuttige adviezen met betrekking tot mijn functioneren.

- Voldoende aandacht besteed aan anamnese, lichameliik onderzoek, interpretatie van gegevens, $D D$, therapie en aanvullend onderzoek. $\quad 1 \quad 2 \quad 3445$

De doelen voor deze stage in aanmerking genomen werd door de begeleiders voldoende aandacht besteed aan:

- Verslaglegging.

- Fysisch-diagnostische vaardigheden. 11203445

- Therapeutische vaardigheden. 1233445 
volledig volledig

5. Aandacht voor de patiënt en zijn context

De doelen voor deze stage in aanmerking genomen werd door de begeleiders voldoende aandacht besteed aan:

- Voorlichting aan patiënten.

- Vervolgen respectieveliik begeleiden patiënten.

- Gesprekstechnische vaardigheden.

- Miin omgang met patiënten.

- Integrale benadering van somatische en psychische aspecten.

- Emoties die bii mii opgeroepen zijn.

- Organisatie gezondheidszorg.

- Kostenaspect van de gezondheidszorg.

- Samenwerking le en 2e lijn.

- Multi-disciplinaire benadering van patiëntproblemen.

- Medisch-ethische aspecten.

- Samenwerking tussen artsen en verpleegkundigen.

$\begin{array}{lllll}1 & 2 & 3 & 4 & 5 \\ 1 & 2 & 3 & 4 & 5 \\ 1 & 2 & 3 & 4 & 5 \\ 1 & 2 & 3 & 4 & 5 \\ 1 & 2 & 3 & 4 & 5 \\ 1 & 2 & 3 & 4 & 5 \\ 1 & 2 & 3 & 4 & 5 \\ 1 & 2 & 3 & 4 & 5 \\ 1 & 2 & 3 & 4 & 5 \\ 1 & 2 & 3 & 4 & 5 \\ 1 & 2 & 3 & 4 & 5\end{array}$

6. Kwaliteit van onderwijsactiviteiten

- Het aantal specifiek voor het onderwijs in groepsverband (los van de routine gezondheidszorg) georganiseerde bijeenkomsten was voldoende. $1 \quad 2 \quad 2 \quad 3 \quad 4 \quad 5$

- Deze bijeenkomsten vond ik leerzaam. $122 \quad 3445$

7. Aanbod van patiëntproblemen

- Het patiëntenaanbod was voldoende gevarieerd.

- Het aantal patiëntproblemen waarmee ik geconfronteerd ben was voldoende.

8. De kwaliteit van patiëntgebonden leersituaties

- Het meelopen met afdelingsvisites was leerzaam.

- De patiëntbesprekingen waren leerzaam. $1 \quad 2 \quad 3 \quad 4 \quad 5$ 
volledig volledig

oneens

eens

Specifiek:

- Het verblijf op de OK was leerzaam. $\quad \begin{array}{llllll}1 & 2 & 3 & 4 & 5\end{array}$

- Het verblijf op de verloskamer was leerzaam.

- Het meedraaien van diensten

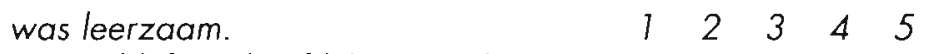

- Het verbliff op de afdeling was leerzaam. $1 \quad 2 \quad 3 \quad 4 \quad 5$

- De röntgenbesprekingen waren leerzaam. $122 \quad 3 \quad 4 \quad 5$

- De PA-besprekingen waren leerzaam. $\quad 1 \quad 2 \quad 3 \quad 4 \quad 5$

9. Kwaliteit van het onderwijs in de polikliniek

- Het verbliff op de poli was leerzaam. $12 \begin{array}{llll}2 & 3 & 4 & 5\end{array}$

- Er was op de poli een ruimte om zelfstandig een patiënt te kunnen onderzoeken. $1 \begin{array}{lllll}1 & 2 & 3 & 4 & 5\end{array}$

10. De kwaliteit van studie-faciliteiten

- Er was een geschikte plaats om te studeren beschikbaar.

$\begin{array}{lllll}1 & 2 & 3 & 4 & 5\end{array}$

- Als ik er behoefte aan had kon ik van de beschikbare leermiddelen gebruik maken.

- De leermiddelen waren inhoudelijk Specifiek: van voldoende kwaliteit.

12345
12345

- Er waren voldoende ruimtelijke voorzieningen beschikbaar voor de avond-, nacht en weekenddiensten. $\quad 1 \quad 2 \quad 3 \quad 3445$

11. De kwaliteit van de stagebeoordeling

- De stagebeoordeling vond plaats op het afgesproken tijdstip.

- De wijze van beoordeling vond plaats zoals afgesproken.

- Het is mii duidelijk op grond van welke informatie ik beoordeeld ben.

$\begin{array}{lllll}1 & 2 & 3 & 4 & 5 \\ 1 & 2 & 3 & 4 & 5 \\ 1 & 2 & 3 & 4 & 5\end{array}$

12. Gelegenheid tot zelfstudie

- De stage liet voldoende ruimte voor zelfstudie.

12345 
13. Algemeen oordeel over de stage (schoolcijfer 1-10)

- Geef een schoolciifer voor de werksfeer.

- Geef een schoolciifer voor de leerzaamheid.

- Geef een schoolciifer voor de organisatie.

14. Tijdsbesteding tiidens de slage

- Het aantal uren dat ik gemiddeld per week in het ziekenhuis aanwezig was (inclusief diensten) bedroeg ..... uren per week.

- Buiten miin stagewerktijd studeerde ik nog gemiddeld ..... uren per week.

- Het aantal uren dat ik aan niet leerzame activiteiten besteedde nam gemiddeld uur per week in beslag.

\subsection{Samenvatting}

In dit hoofdstuk is de constructie van het meetinstrument besproken. Uit onderzoek blijkt dat kenmerken van de stageplaats, met name de begeleiding, het meest bepalend zijn voor een effectieve stages. Op het gebied van klinisch onderwijs is er weinig onderzoek vitgevoerd dat gericht is op kwaliteitskenmerken in brede zin. Onderzoek naar kenmerken van klinische settings richt zich hoofdzakelijk op kenmerken waaraan begeleiders dienen te voldoen. Op basis van deze studies zijn veertien domeinen onderscheiden waaraan co-assistentschappen zouden moeten voldoen. Deze domeinen hebben als uitgangspunt gediend voor de constructie van een instrument om de kwaliteit van co-assistentschappen te meten. 


\section{Interpretatie van evaluatiegegevens}

In het voorafgaande hoofdstuk is de constructie van de vragenlijst voor stage-evaluatie besproken. Het instrument bevat 14 domeinen, die geoperationaliseerd zijn in items. Om zicht te kriigen op kwaliteit van een stage, kennen studenten na afloop van elke stage aan 53 items en eventueel enkele stagespecifieke items een score toe. Een volgende stap is om deze scores re interpreteren. De centrale vraag hierbij is wanneer een score "voldoende" of "onvoldoende" is. Deze interpretatie vereist de beschikbaarheid van normen. In paragraaf 6.1 wordt een algemene toelichting gegeven bij het interpreteren van evaluatiegegevens. Paragraaf 6.2 . geeft een overzicht van de verschillende typen normen. Paragraaf 6.3 beschriift het gebruik van normen in de praktijk. In paragraaf 6.4 volgt een samenvatting.

\subsection{Interpretatie van gegevens: een inleiding}

In het kader van deze studie is een vragenlijst geconstrueerd die bedoeld is als hulpmiddel om uitspraken re doen over de kwaliteir van stages. Dit instrument heeft primair een evaluatieve functie. De vitkomsten moeten helderheid geven van datgene dat in een stage moet veranderen. De vragenlijst bestaat uit 53 items die bij alle stages aan de orde komen. Daarnaast zijn er 7 items die gekoppeld zijn aan bepaalde stages. De items hebben betrekking op 14 domeinen. Aan het einde van elke stage vullen de studenten een vragenlijst in. De volgende stap is om scores te berekenen en hieraan betekenis te geven. Ten behoeve van de interpretatie zijn twee uitgangspunten geformuleerd. In de eerste plaats moeten de vitspraken betrekking hebben op de afzonderlijke domeinen. Een domein bevat items die betrekking hebben op één en hetzelfde gebied. Bij de samenstelling van domeinen is zoveel mogelijk gestreefd naar herkenbare eenheden. Bijvoorbeeld tot het domein van de "faciliteiten" behoren irems met betrekking tot de beschikbare leermiddelen op de stageplaats, de kwaliteit van de leermiddelen, en de beschikbare studieruimte. Een en ander met hel oog op de mogelijkheid 
van berekening van gemiddelde scores per domein. Daarnaast zijn scores op itemniveau noodzakelijk om gedetailleerde aanwijzingen te krijgen van de aspecten die moeten veranderen. Stel de totaalscore voor het domein "Faciliteiten" is laag, dan moet vastgesteld worden welke aspecten relatief laag scoren, bijvoorbeeld: moet dit resultaat toegeschreven worden aan de beschikbare leermiddelen, de kwaliteit van de leermiddelen, of aan de beschikbare studieruimte? Kortom itemscores vormen een goed startpunt voor concrete veranderingen. Het tweede uitgangspunt is dat uitspraken gedaan kunnen worden op twee niveaus. Enerzijds kunnen uitspraken gedaan worden op het niveau van de stage, bijvoorbeeld de stage interne geneeskunde, en anderziids op het niveau van de stageplaats, bijvoorbeeld de stage interne geneeskunde binnen het Academisch Ziekenhuis Maastricht. Hierbij is de volgende gedachtengang gevolgd. In het vijfde en zesde jaar lopen de studenten, afgezien van de psychomedische stage, co-assistentschappen binnen acht verschillende klinische disciplines. Elke slage heeft specifieke kenmerken. Dat vraagt mogelijkerwijs om maatregelen, die disciplineafhankelijk zijn. Bijvoorbeeld de stage interne geneeskunde zal andere eisen aan de voorkennis van studenten stellen dan de stage oogheelkunde. Om in deze vitspraken te kunnen doen, zijn gegevens op het niveau van de stage vereist. De onderzoeksbetreffende stages worden gelopen in ziekenhuizen. Elke stageplaats heeft zijn eigen kenmerken, wat bij negatief afwijkende scores vraagt om bijstellende maatregelen, specifiek toegesneden op het desbetreffende ziekenhuis. Bijvoorbeeld wanneer de score voor het domein "faciliteiten" voor de stage interne geneeskunde in het Academisch Ziekenhuis Maastricht laag is, vraagt dit om faciliteiten verbeterende maatregelen op deze lokatie. Gegevens op het niveau van de stageplaats zijn hiervoor noodzakelijk. Hieruit volgt dat na de interpretatie van gegevens, rapportage moet plaatsvinden voor de afzonderlijke domeinen onderscheiden naar stage én naar stageplaats.

Het vertrekpunt voor de interpretatie zijn de waarderingen van de studenten. Over de feitelijke situatie wordt aan de hand van een aantal items door studenten een oordeel gegeven. Een domeinscore komt tot stand door de gemiddelde scores van de items behorende tot hel betreffende domein te middelen. Dit betekent dat een domeinscore evenals de itemscores minimaal 1 en maximaal 5 bedraagl. Een vitzondering hierop vormt het domein "algemeen oordeel". De student beoordeelt de drie hiertoe behorende items met behulp van een schoolciifer van 1 lot 10. Dit betekent dal de domeinscore voor het algemeen oordeel bestaat uit het gemiddelde van de scores op deze items, dat varieert lussen 1 en 10 . De berekening van de domeinscore op het niveau van de stage gebeurt door hierin 
de waarderingen van alle studenten te betrekken. De berekening van de domeinscore op het niveau van de stageplaats betreft vitsluitend de waarderingen van die sludenten die stage hebben gelopen op de betreffende lokatie. De interpretatie van scores vindt altijd plaats door een feitelijke situatie (F) re vergelijken mel een gewenste situatie $|G|$. De gewenste situatie wordt geoperationaliseerd in een norm. De norm geeft de minimale score aan die behaald moet worden om van acceptabele kwaliteit te kunnen spreken. Vergelijking van de feitelijke situatie met de norm brengt eventuele discrepanties aan het licht. Drie uitkomsten zijn mogelijk. De eerste is dat er geen discrepanties zijn, dat wil zeggen: de feitelijk gegevens zijn conform de gestelde normen $(F=G)$. De tweede mogelijkheid is dat de feitelijke gegevens boven de gewenste situatie liggen, dat wil zeggen: er is sprake van een positieve discrepantie. In deze beide gevallen is er geen directe aanleiding om veranderingen in de stage aan te brengen ( $F>G)$. In de derde plaats kan sprake zijn van een negatieve discrepantie, dat wil zeggen: de feitelijke gegevens liggen onder de norm voor de gewenste situatie. Dit vraagt om voorstellen tot optimalisering van de stage die de discrepantie opheffen $[\mathrm{F}<\mathrm{G}]$, leidend tot maatregelen ter verbetering van de feitelijke situatie, bijvoorbeeld door de begeleiding binnen stages beter te organiseren, meer ruimtelijke faciliteiten voor studenten beschikbaar te stellen. Een andere mogelijkheid is om de normen bij te stellen. Dat kan nodig zijn als pogingen lot verbetering over de hele linie gefaald hebben. De bijgestelde norm is dan blijkbaar wat haalbaar is in de betreffende stage. In figuur 3 zijn de mogelijke beslissingen schematisch weergegeven (Provus, 1971).

Mogelijke beslissingen op basis van discrepanties

Figuur 3 tussen de feitelijke en gewenste situatie

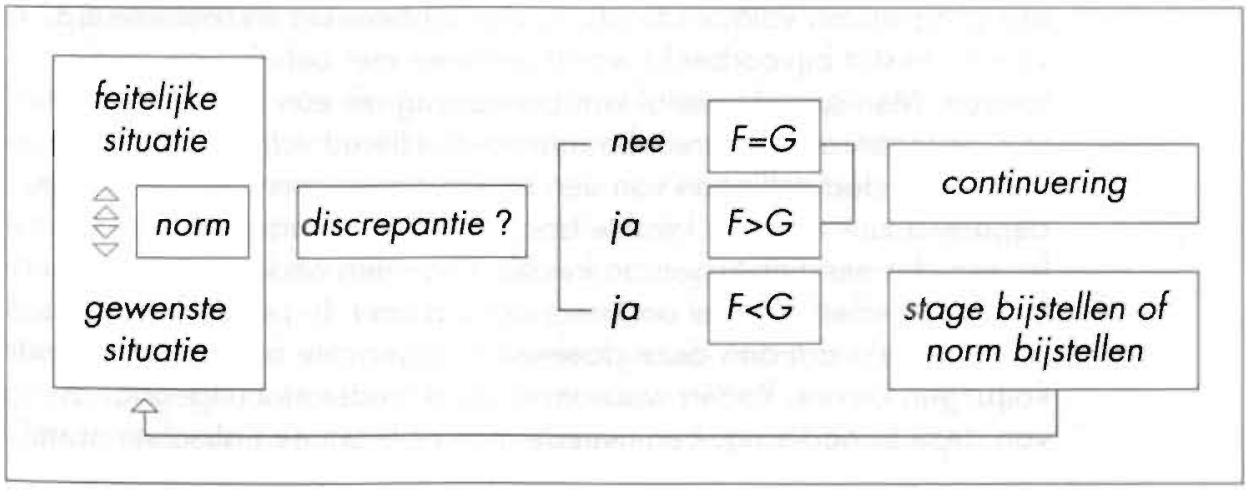


Er zijn diverse manieren om tot normen te komen. Op de wijze waarop de norm in deze studie gedefinieerd wordt, gaat de volgende paragraat nader in.

\subsection{Normen}

Door de ideale situatie met de feitelijke situatie te vergelijken wordt een waarde-oordeel over de kwaliteil gegeven in termen van een "voldoende" of "onvoldoende". Dit vraagt om het stellen van normen waartegen het feitelijke resultaat van de evaluatie afgezet kan worden. De vraag is hoe hoog de scores moeten zijn, wil nog van een voldoende kwaliteit gesproken worden. De norm geeft de score aan die minimaal behaald moet worden, wil van acceptabele kwaliteit gesproken worden. Het is natuurlijk mogelijk om een dergelijke norm op intuitieve gronden vast te stellen. Uiteraard is het beter om dit op grond van rationele motieven te doen. Normen kunnen op diverse wijzen bepaald worden. In de literatuur wordt een onderscheid gemaakt in drie methoden 1) absolute normering 2) relatieve normering 3) zelfgerichte normering (de Grool \& van Naerssen, 1969; Livingston \& Zieky, 1982; Mehrens \& Lehman, 1984; Wijnen, 1977). Het hiernavolgende beschrijft de kenmerken van relatieve, absolute en zelfgerichte normen en de betekenis hiervan voor de stage-evaluatie.

\subsubsection{Absolute normen}

Het kenmerk van absolute normeringsmethoden is dat scores vergeleken worden met een vooraf gedefinieerde norm. Absolute normen komen op directe of op indirecte wijze tot stand. De eerste mogelijkheid wordl gepropageerd door aanhangers van de doelstellingengerichte benadering (Tyler, 1950). In hun optiek is de kwaliteit van een programma voldoende als de doelen bereikt zijn. Beheersing van studiestof bijvoorbeeld wordt gemeten met behulp van studietoetsen. Men spreekt veelal van beheersing als een leerling $80 \%$ van de toetsvragen correct beantwoordt. Hieruit volgt dat de mate waarin de doelstellingen van een onderwijsprogramma bereikt zijn, bepalend zijn voor het kwaliteitsoordeel van het programma. $\mathrm{Zij}$ leggen dus een link iussen de kwaliteit van een onderwijsprogramma en het effect van het onderwijsprogramma. In paragraaf 4.2 is reeds gesteld dat aan deze doelstellingengerichte benadering tekortkomingen kleven. Reden waarom in deze studie niet uitgegaan is van deze benadering. Een tweede manier is om een absolute norm 
af te leiden uit de inhoud van het evaluatieinstrument. Een relevante respondentgroep - veelal docenten - geeft aan welke scores minimaal behaald moeten worden wil van acceptabel onderwijs gesproken worden. Een dergelijke benadering hanteert het ISEK-systeem, dat uitspraken doet over de kwaliteit van cursussen (Jansen, 1990). De docenten geven per item een zogenaamd grenspercentage aan Onder dit percentage verstaat men het percentage antwoorden dat voor de docent de grens markeert fussen problematische en niel problematische uitkomsten. Het voordeel van absolute normen is dat docenten duidelijk expliciteren aan welke eisen een programma moet voldoen en daardoor een directe relatie legt met het gegeven onderwijs. Bij het vaststellen van een absolute norm komt de "gewetensvraag" aan de orde van de eigenlijke minimum eisen waaraan een onderwijssetting zou moeten voldoen (de Groot \& van Naerssen, 1969). Het nadeel van absolute normen is dat het zeer moeilijk is om de eisen waaraan een programma moet voldoen exact in een score vit te drukken. Al naar gelang de betrokkenheid bij het onderwijs zullen de meningen hierover verschillen, zodat het moeilijk is om toł aanvaardbare normen te komen. Uit een onderzoek dat verricht is naar begeleiding tijdens het co-assistentschap gynaecologie/obstetrie blijkt dat studenten aan andere aspecten van de begeleiding belang hechten dan artsen en onderwijsdeskundigen (Wolfhagen et al., 1992). Gevolg is dat het moeilijk is om tot een eenduidige norm te komen. Een ander daarmee samenhangend probleem is wanneer docenten voorgeschreven normen als niet-realistisch ervaren. In dergelijke gevallen werken normen contra-productief. Bii het vaststellen van de norm zal daarom terdege rekening gehouden moeten worden met datgene wat docenten reëel én haalbaar vinden. Bovendien is onbekend wat de schaalwaarden in absolute zin voorstellen, daarom wordt bij evaluaties veelal gebruik gemaakt van relatieve normen.

\subsubsection{Relatieve normen}

Het kenmerk van relatieve normeringsmethoden is dat de norm ontleend wordt aan de resultalen van een referentiegroep. Als referentiegroep fungeert een groep die representatief is voor het onderwerp waarover een vitspraak gedaan wordt. De norm wordt vastgesteld op basis van de scores die de referentiegroep heeft behaald. $\mathrm{Bii}$ studietoetsen wordt veel gebruik gemaakt van relatieve normen. Hierbij fungeert de jaargroep of leeftijdsgroep veelal als referentiegroep (Dousma \& Horsten, 1980; Rommes, 1978; Wijnen, 1971). Ook bij evaluatie van onderwijsprogramma's wordt veelvuldig 
gebruik gemaakt van relatieve normen. Het SEEQ-systeem vergelijkt cursussen onderling om vast te stellen of een cursus goed of slecht gefunctioneerd heeft (Marsh, 1982). Systemen voor cursusevaluatie zoals hel IOWO-DOE systeem en OSO maken gebruik van relatieve normen; zij het gecombineerd met een absolute norm. Ook Gijselaers (1988) maakt bii de evaluatie van onderwijsprogramma's gebruik van relatieve normen. Door onderwijsprogramma binnen een jaarcohort onderling te vergelijken, worden slecht scorende programma's gesignaleerd. Het nadeel van relatieve normen is dat oordelen over de kwaliteit van een programma afhankelijk gemaakt worden van de kwaliteit van andere programma's. Wanneer de kwaliteif van alle programma's laag is, resulteert dit in lage normen met dientengevolge lage kwaliteitseisen. Een ander nadeel is dat de norm bepaald wordt door studenten die het programma hebben gevolgd. De docenten hebben daardoor geen invloed op de normstelling, waardoor de discussie over wat goed onderwijs is, op de achtergrond raakt. Het voordeel van relatieve normen is, dat deze ontleend worden aan de vigerende praktijk en daardoor realistisch zijn. Met andere woorden er wordt rekening gehouden met datgene wat blijkbaar haalbaar is in stages, wat een stimulans zal zijn om maatregelen te treffen die de kwaliteit van de stage verhogen. Het is problematisch om bij het vaststellen van relatieve normen een geschikt criterium te vinden. Bij het ontbreken hiervan wordt binnen de testheorie veelal "het gemiddelde" als de beste schatter beschouwd van wat blijkbaar haalbaar is. Dit principe kan naar de programma-evaluatie vertaald worden. Een programma is van onvoldoende kwaliteit als de score te veel onder de gemiddelde score ligt. Hoe groot de toegestane afwiiking mag zijn om nog van voldoende kwaliteit te spreken, ligt niet eenduidig vast. Hiervoor zijn wederom diverse methodes ontwikkeld. Een veel gehanteerde manier is om de toelaatbare afstand tot het gemiddelde van de respondentgroep te definiëren met behulp van de standaardmeeffout. Hierbij houdt men rekening mel de onbetrouwbaarheid van de meting. Vaak wordt uitgegaan van een $95 \%$ betrouwbaarheidsinterval dat wil zeggen een score is voldoende als de gemiddelde score voor een programma gelijk is aan het gemiddelde van de referentiegroep minus twee standaardmeetfoulen (Wijnen, 1971). 


\subsubsection{Zelfgerichte normering}

Een laarste mogelijkheid ter normering is om normen te ontlenen aan voorafgaande metingen, die bij hetzelfde object hebben plaatsgevonden. In feile is hier ook sprake van een relatieve norm. Deze methode is bruikbaar als er de beschikking is over meerdere metingen. Voortuitgang of achteruitgang van een programma kan vastgesteld worden door metingen onderling te vergelijken. Gijselaers (1988) gebruikt deze methode om vast te stellen of veranderingen in een programma geleid hebben tot het beoogde effect. Het voordeel van deze methode is dat de kwaliteit van een programma over een tijdsperiode gevolgd kan worden. Deze methode signaleert wanneer er verhoging c.q. verlaging van de kwaliteit is opgetreden. Een nadeel is dat er niet gerefereerd wordt naar andere programma's, waardoor de kwaliteitseisen uitsluitend ontleend worden aan het eigen programma. Zelfgerichte normen kunnen dan ook nooit een volledige vervanging zijn maar zullen altijd gebruikt worden naast absolute of relatieve normen, waarbij bijvoorbeeld de jaargroep als referentiegroep wordt gehanteerd.

\subsubsection{Samenvatting}

Uit het voorgaande is duidelijk geworden dat elke normeringsmethode naast zijn merites zijn tekortkomingen kent. In figuur 4 zijn de voor-en nadelen met kernwoorden weergegeven.

Voor- en nadelen van de verschillende normeringsmethoden

\begin{tabular}{|lll|}
\hline Normen & Voordeel & Nadeel \\
\hline Relatief & $\begin{array}{l}\text { Haalbaarheid voor } \\
\text { iedereen }\end{array}$ & Normvervaging \\
Absoluut & $\begin{array}{l}\text { Continue discussie } \\
\text { over onderwijs }\end{array}$ & Niet altijd realistisch \\
Zelfgericht & Effecten vaststellen & $\begin{array}{l}\text { Geen relatie met andere } \\
\text { programma's }\end{array}$ \\
\hline
\end{tabular}


Uit figuur 4 valt af te leiden dat er eigenlijk geen ideale normeringsmethode bestaat. Het is zaak om zoveel mogelijk te profiteren van de voordelen van elke methode. Dit pleit om bij de stage-evaluatie gebruik te maken van gecombineerde normen. Relatieve normen bieden de meeste voordelen. Daarom is besloten om deze bij de interpretatie als vertrekpunt te nemen. Een essentiële vraag hierbij is welke referentiegroep bij de stage-evaluatie het meest adequaat is. Hierbij moeten de uitgangspunten voor de interpretatie in acht worden genomen (zie paragraaf 6.1). Informatie moet beschikbaar zijn per domein op het niveau van de stage én de stageplaats. Bij coassistentschappen zijn diverse referentiegroepen mogelijk. Als referentiegroep zouden de beoordelingen van alle studenten over de diverse klinische stages kunnen fungeren. Immers deze stages hebben met elkaar gemeenschappelijk dat ze allen in een klinische setting plaatsvinden. De opzet is in wezen identiek en ze moeten strikt genomen aan dezelfde eisen voldoen. Een indicatie van de kwaliteit kan verkregen worden door deze klinische stages onderling te vergelijken. Deze methode geeft een algemene indicatie van de kwalireit van een stage in relatie tot de andere stages. Het voordeel daarvan is dat de normen ontleend worden aan het gehele klinische onderwijs. Het nadeel is dat geen rekening gehouden wordt met de specifieke aspecten van een discipline en met de locatie. Daarom verdient het aanbeveling om daarnaast gebruik te maken van een tweede mogelijkheid waarbij men stages binnen een dezelfde discipline als referentiegroep beschouwt. Het voordeel daarvan is dat rekening wordt gehouden met de eigenschappen van een discipline. Het nadeel is dat geen rekening wordt gehouden met de eigenschappen van de stageplaats (ziekenhuis). Hieruit komt de derde mogelijkheid voort om de stageplaats zelf als referentiegroep te beschouwen. Elke stageplaats zal afdelings- en disciplinegebonden kenmerken hebben. Vanuit deze visie ligt het voor de hand om een sterkte-zwakte-analyse te maken van een stage in een bepaald ziekenhuis zonder andere stageplaatsen hierbij te betrekken. Een kwaliteitsindicatie van de domeinen wordt verkregen door de scores op de domeinen onderling te vergelijken. Bij de keuze van de referentiekaders verschuift de functie van evaluatie van algemene screening naar specifieke taxatie. Afhankelijk van de doelstelling zal gewerkt worden met drie verschillende referentiekaders: klinische stages, disciplines en/of de "eigen" stageplaats. Een nadeel van relatieve normen is dat deze kunnen leiden tot lage kwaliteitseisen ingeval door de referentiegroepen lage scores toegekend worden. Om dit te voorkomen wordt een absolute ondergrens ingesteld. Een score beneden deze ondergrens is in ieder geval onvoldoende, ongeacht de scores van de referentiegroepen. De vragenlijst bestaat vit items 
in de vorm van stellingen die voorzien zijn van een vijfpuntsschaal. Score 3 geeft de "neutrale positie" op de schaal weer. De domeinscore bestaat uit het gemiddelde van alle betreffende itemscores. Daarom is besloten om een score van lager dan 3 in ieder geval als kritieke grens op te vatten, ongeacht de hoogte van de relatieve norm.

Stage-evaluatie is een continue proces. Van elke slage zijn gegevens op meerdere meetmomenten beschikbaar. Om de vooruitgang c.q. achteruitgang van een stage vast te stellen, behoort het gebruik van zelfgerichte normen tot de mogelijkheden. Hierbij worden meerdere opeenvolgende metingen onderling vergeleken. Bovenstaande overwegingen leiden tot het gebruik van relatieve normen, waarbij een absolute ondergrens gehanteerd wordt. Om veranderingen binnen een stageplaats vast te stellen wordt daarbii gebruik gemaakt van zelfgerichte normen.

\subsection{Toepassing van normen in de praktijk}

In het hiernavolgende wordt aan de hand van enkele praktiikvoorbeelden geillustreerd op welke wijze normen gehanteerd worden. De interpretatie van gegevens gebeurt aan de hand van diverse typen profielen, die geanalyseerd worden. Hoe deze procedure werkt zal worden geillustreerd (Gijselaers \& Wolthagen, 1989; Wolfhagen, Gijselaers, Stalenhoef \& Essed, 1989; Wolfhagen \& Gijselaers, 1990).

Van alle klinische stages worden voor de onderscheiden domeinen jaarlijks profielen gemaakt. In een profiel staan horizontaal de scores vermeld (1-5) en verticaal de stages. Het profiel geeff de gemiddelde domeinscore grafisch weer. De domeinscores komen tot stand door de scores op de bijbehorende items te middelen. Inspectie van de profielen laat voor elk domein zien welke stages relatief laag, gemiddeld of hoog scoren. Hiermee wordt dus een algemene kwaliteitsindicatie verkregen en kunnen aandachtspunten op disciplineniveau geformuleerd worden. Deze informatie is met name voor beleidsmakers van belang. Bijvoorbeeld, welke stage scoort voor het domein "persoonsgebonden begeleiding" laag in vergelijking met de andere disciplines. Wat is hiervan de oorzaak? Moeten hiervoor maatregelen genomen worden? In figuur 5 is een voorbeeld van een profiel afgebeeld voor het domein "persoonsgebonden begeleiding". 


\section{Domein}

Dermatologie

KNO

Oogheelkunde

Neurologie

Kindergeneeskunde

Gynaecologie/verloskunde

Chirurgie

Interne geneeskunde

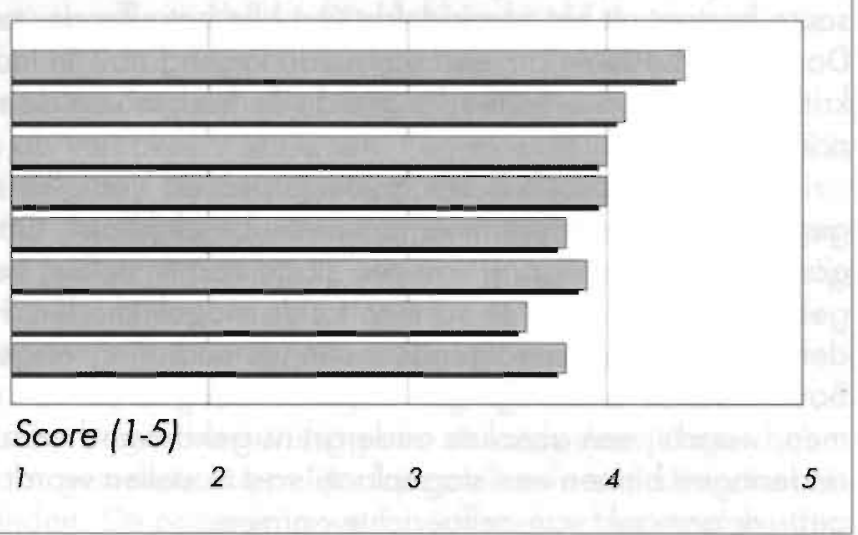

Figuur 5 Overzicht van de scores voor het domein "persoonsgebonden begeleiding" van klinische stages (data 1991)

Uit figuur 5 blijkt dat er tussen stages geen grote verschillen zijn. In het voorbeeld scoort de stage chirurgie relatief laag en de stage dermatologie relatief hoog. Absoluut gezien liggen alle scores boven de als ondergrens gestelde norm. Echter op basis hiervan verkrijgt men geen uitsluitsel over eventuele verschillen tussen stageplaatsen. Een volgende stap is dan ook om per discipline inzicht te krijgen in mogelijke verschillen tussen ziekenhuizen. Daarom wordt per discipline een profiel voor de onderscheiden domeinen gemaakt. In een dergelijk profiel staan horizontaal de scores (1-5) en verticaal de ziekenhuizen vermeld. Het profiel geeft de gemiddelde domeinscore per ziekenhuis grafisch weer. De domeinscores komen tot stand door de scores op de bijbehorende items per stageplaats te middelen. Inspectie van de profielen laat zien welke stageplaatsen relatief laag, gemiddeld of hoog scoren. Hiermee wordt dus een kwaliteitsindicatie verkregen op het niveau van de discipline onderscheiden naar ziekenhuis en kunnen aandachtspunten per stageplaars geformuleerd worden. Deze informatie is met name voor de ziekenhuizen van belang. Bijvoorbeeld, in welke ziekenhuis scoort de persoonsgebonden begeleiding laag in vergelijking met de andere ziekenhuizen. Wat is hiervan de oorzaak? Hoe is de begeleiding gerealiseerd in het betreffende ziekenhuis? In figuur 6 is een voorbeeld van een profiel afgebeeld voor het domein "persoonsgebonden begeleiding" van de slage chirurgie. Deze stage vindt plaats op vier verschillende lokaties. 


\section{Ziekenhuis}

affiliatie 3

affiliatie 2

affiliatie 1

$A Z M$

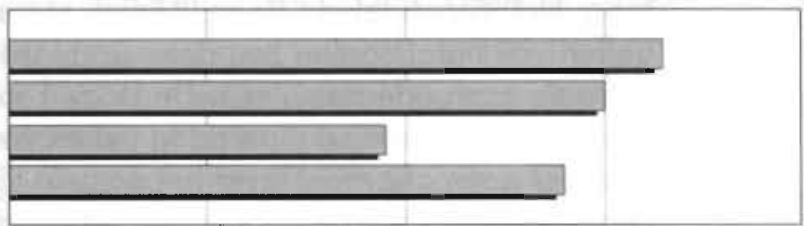

Score (1-5)

1

Grafische weergave van score voor het domein "persoonsgebonden begeleiding" van de stage chirurgie per ziekenhuis (data 1988)

Uit figuur 6 blijkt dat er fussen de ziekenhuizen verschillen zijn. In dit voorbeeld scoort de persoonsgebonden begeleiding in affiliatieziekenhuis 1 relatief laag. Bovendien is de score ook absoluut gezien laag. Hiervit kunnen aandachtspunten voor een stage op ziekenhuisniveau geformuleerd worden. De overige ziekenhuizen worden beter beoordeeld. Hieruit volgt dat een hogere beoordeling haalbaar is. Bij het treffen van maatregelen zal viteraard rekening gehouden worden mel de situatie in hel betreffende ziekenhuis.

Een volgende mogelijkheid is om voor de stageplaats een profiel te maken waarin alle domeinen zijn afgebeeld. In het profiel staan horizontaal de scores (1-5) en verticaal de domeinen vermeld. Dit profiel geeft de gemiddelde domeinscore grafisch weer. De domeinscores komen tot stand door per stageplaats de scores op de bijbehorende items te middelen. Inspectie van de profielen laat zien welke domeinen binnen een stageplaats relatief laag, gemiddeld of hoog scoren. Er vindt mel andere woorden een sterkte-zwakte analyse plaats. Op basis hiervan kan bepaald worden welke aspecten van een stageplaats verbeterd kunnen worden. Het voordeel hiervan is dat niet alle slecht-scorende aspecten tegelijkertijd "aangepakt" behoeft te worden, maar dat prioriteit gegeven kan worden aan het (relatief) laagst scorende domein. Dit heeft voor docenten een motiverende werking, doordat gericht aan de verbetering van de desbetreffende domeinen kan worden gewerkt. In figuur 7 is ter illustratie het profiel van het co-assistentschap chirurgie voor affiliatieziekenhuis 1 afgebeeld. 
In figuur 7 scoren de begeleiding medisch-technisch, de aandacht voor patiënt en context en de zelfstudie zowel absoluut als relatief laag. Het stageboek en de polikliniek scoren relatief hoog. Bij het treffen van maatregelen zou deze stage prioriteit moeten geven aan de laagstscorende domeinen. De stage kan deze gegevens gebruiken om een activiteitenplan op te stellen voor de komende jaren. $\mathrm{Er}$ zijn hier geen gegevens over hel domein tijdsbesteding opgenomen. Deze gegevens worden normaliter separaat vermeld.

Met hel oog op kwaliteitsbewaking is het zinvol om regelmatig evaluatiegegevens te verzamelen en de desbetreffende scores minimaal jaarlijks met voorgaande metingen te vergelijken zodat vastgesteld kan worden of er wijzigingen in de situatie zijn opgetreden. In figuur 8 is ter illustratie de score voor persoonsgebonden begeleiding op vijf meetmomenten afgebeeld. Horizontaal staan de scores (1-5) vermeld en verticaal de diverse meetmomenten.

Figuur 7 Voorbeeld van een profiel van de stage chirurgie in affiliatieziekenhuis I (data 1989)

Domein

Algemeen oordeel

Zest $F_{\text {studie }}$

Stagebeoordeling

Studiefuciliteiten

Polikliniek

Patiëntgebonden leersituaties

Aanbod patiëntproblemen

Onderwijsactiviteiten

Aandacht patiënt + context

Begel. medisch-fechnisch

Persoonsgebonden begel.

Stageboek

Voorbereiding

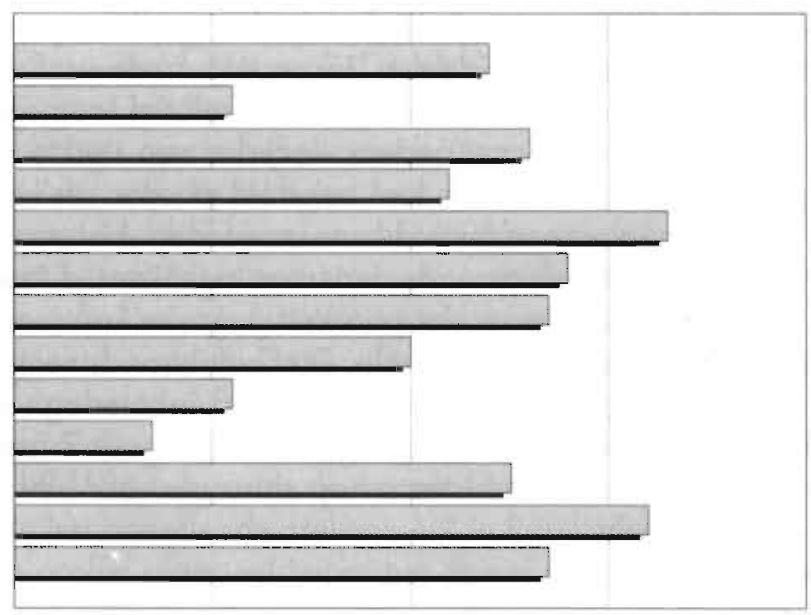

Score (1.5)

1

2

3 
Uit figuur 8 blijkt dat het domein "persoonsgebonden begeleiding", in 1988 een dip vertoont. Eind 1988 zijn vervolgens maatregelen getroffen om de begeleiding te verbeteren. Dit heeft in 1989 een stijging van de score tol gevolg, die voortzet in 1990. In 1991 is er wederom een afname. Voor het betreffende ziekenhuis moet dit een signaal zijn om de nodige aandacht blijven te besteden aan de begeleiding zodat de kwaliteit gewaarborgd bliift. Opgemerkt dient te worden dat progressie in een score niet automatisch behoeft te betekenen dat verdere verbetering overbodig is. Een domeinscore kan in vergelijking met soortgelijke stageplaatsen en/of met alle klinische stages nog steeds aan de lage kant zijn en heeft dan speciale aandacht nodig. Daarom is het zinvol om de scores van een bepaalde stage ook te vergelijken met die van andere stages. Uiteraard is het belangrijk om na te gaan in hoeverre de verschillen van betekenis zijn en niet het gevolg zijn van meetfouten. Daarom is het belangrijk een indicatie te hebben van de standaardmeetfout. In hoofdstuk 9 wordt hierop nader ingegaan.

Vergeliiking van de scores voor het domein "persoonsgebonden begeleiding" van de stage chirurgie in affiliatieziekenhuis 1 op vier meetmomenten (1987.1991)

Jaar

1991

1990

1989

1988

1987

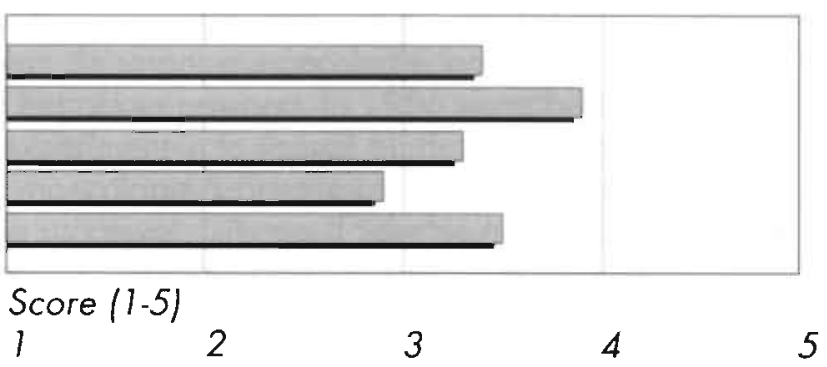




\subsection{Samenvatting}

De studenten vullen aan het einde van elke stage een vragenlijst in over de kwaliteit van de stage. De gegevens moeten indicaties geven voor de verbetering van stages. Met het oog op de praktische bruikbaarheid is gekozen voor rapportage per domein, onderscheiden naar de stage èn de stageplaats. De evaluatiegegevens worden in profielen weergegeven, die vervolgens geanalyseerd worden. Dit vereist de beschikbaarheid van normen. Hier worden drie typen normen onderscheiden, namelijk relatieve, absolute en zelfgerichte. Elk type kent zijn voor- en nadelen. Om zoveel mogelijk gebruik te maken van de voordelen van elk type, is hier gekozen voor gecombineerde normen. Relatieve normen zijn het vertrekpunt voor de interprelatie, waarbii gebruik gemaakt wordt van drie referentiekaders. Allereerst dat van de stages om een algemene kwaliteitsindicatie te kriigen. Ten tweede dat van de discipline om een beeld te krijgen van de stageplaatsen in de diverse ziekenhuizen. Ten derde dat van de eigen stageplaats om inzicht te kriigen in de sterke en zwakke punten binnen een stageplaats. Naast relatieve normen geldt een absolute ondergrens ter bewaking van een zeker minimumniveau. Om effecten binnen een stage of stageplaats vast te stellen wordt gebruik gemaakt van zelfgerichte normen ter signalering van voorvitgang of achteruitgang. 


\section{Stage-evaluatie in de praktijk}

In 1987 stelde de Faculteit der Geneeskunde dat het aanbeveling verdiende de kwaliteit van alle klinische stages met eenzelfde instrument te evalueren. De bedoeling was om op basis van deze evaluatie een indicatie te krijgen van de kwaliteit van de stages en aanwijzingen te ontvangen over sterke en zwakke aspecten ten behoeve van kwaliteitsverbetering. Stage-evaluatie vond voordien op vrijwillige basis bij slechts enkele stages. Invoering op grote schaal kan in zoverre als een vernieuwingsactiviteit beschouwd worden. Dit vroeg om maatregelen die de invoering én het gebruik van een sysrematische evaluatie in alle stages zouden bevorderen. Dit hoofdstuk beschrijft de realisatie van de stage-evaluatie in de praktijk. Paragraaf 7.1 gaat in op de voorgeschiedenis van programma-evaluatie. Paragraaf 7.2 beschrijft factoren die van invloed zijn op vernieuwingen. In paragraaf 7.3 geeft aan op welke wijze deze factoren vertaald zijn in concrete maatregelen. Paragraaf 7.4 geeft aan de hand van drie voorbeelden een illustratie van de wijze waarop de evaluatiegegevens een functie kunnen vervullen binnen het onderwijs.

\subsection{Inleiding}

Sedert de oprichting van de Medische Faculteit Maastricht werd de nodige aandacht besteed aan de evaluatie van programma's. Deze evaluatie richtte zich hoofdzakelijk op het onderwijs in de eerste vier studiejaren. Vanaf 1986 breidden de evaluatieactiviteiten zich uit naar studiejaar 5 en 6 . Bij de ontwikkeling van de vragenlijst waren de coördinatoren van de stages gynaecologie/obstetrie en kindergeneeskunde actief betrokken geweest. In 1986 werd besloten om de vragenliist als experiment in te voeren bij deze beide stages. Zowel bij de stage gynaecologie/obstetrie als kindergeneeskunde verliep de invoering succesvol. Uiteraard speelde het hierbii een rol dat de betreffende coördinatoren geparticipeerd hebben bij de ontwikkeling van het instrument (zie hoofdstuk 5). De stagecoördinatoren waren van mening dat de gegevens zicht gaven op de 
sterke en zwakke aspecten van hun stage en aanwijzingen verschaften voor veranderingen. Op basis van deze positieve ervaringen werd in 1987 besloten de vragenlijst op grote schaal in te voeren. Aan alle stagecoördinatoren werd gevraagd om de studenten aan het einde van de stage een dergelijke evaluatielijst te laten invullen. Het al dan niet verstrekken van evaluatieformulieren aan studenten werd hierdoor athankelijk van de stagecoördinatoren. In 1987 was hel aantal ingevulde vragenlijisten voor de stages gynaecologie/obstetrie en kindergeneeskunde hoog, respectievelijk $84 \%$ en $82 \%$. Voor de andere stages varieerde de respons van $20 \%$ to $61 \%$. Het was onduidelijk op welke gronden studenten een lijst al dan niet hadden ingevuld.

Een geringe respons behoeft nier automatisch behoeft te betekenen dat de gegevens onbruikbaar zijn. Immers wanneer een kleine groep studenten aspecten van een stage onvoldoende beoordeeld, dan is dit in ieder geval een signaal om nadere aandacht aan het betreffende aspect te besteden. Wanneer vooraf afspraken zijn gemaakt over de wijze van steekproeftrekking, is het overigens niet noodzakelijk dat de hele populatie aan het einde van hun stage een vragenlijst invult. Het is mogelijk at random een aantal studenten een lijst te laten invullen, bijvoorbeeld door alle studenten met een "even" studentnummer de lijsten te laten invullen. In dergelijke gevallen kan met een geringer aantal lijsten volstaan worden en kunnen de gegevens als representatief voor de hele populatie beschouwd worden (Janssens, 1983). Hoofdstuk 9 gaat nader in op het aantal studenten dat toereikend is om een betrouwbare vitspraak over de stage te kunnen doen. De evaluatiegegevens werden - ongeacht de hoogle van de respons - met de betreffende stagecoördinator besproken. In de praktijk bleek een lage respons een belemmering om de coördinatoren te stimuleren acties te ondernemen. Bij negatieve resultaten suggereerden zij dat mogelijkerwijs uitsluitend de studenten met "negalieve ervaringen" de vragenlijst zouden hebben ingevuld. Hel gevolg was dat de gegevens geen aanleiding vormden om acties te ondernemen en weinig impact hadden. Deze situatie was voor de toenmalige onderwijscommissie aanleiding om maatregelen te treffen, die tot een hogere respons zouden leiden en de stage-evaluatie formeel zou inbedden in de totale onderwijsorganisatie. In 1987 besloten de onderwijscommissie en de klinisch onderwijscoördinator in overleg met de medewerkers van het project programma-evaluatie om bij de werkzaamheden prioriteit le geven aan de invoering van de stage-evaluatie in studiejaar 5 en 6. 


\subsection{Creëren van een evaluatieklimaat}

Het gebruik van een instrument om systematisch te evalueren en op basis hiervan maatregelen te treffen kan als een vernieuwingsactiviteit gezien worden. Voorheen was er immers nauwelijks aandacht voor een systematische evaluatie van de stages. Studies naar het verloop van innovaties maken duidelijk dat een verandering slechts kans van slagen heeft als aan een aantal voorwaarden is voldaan (Dalin, 1978; Fullan, 1982; Fullan \& Park, 1980; Fullan \& Pomfret, 1977). De volgende elementen zijn noodzakelijk voor een systematisch vernieuwingsproces.

1. Het afsluiten van een contract. Een dergelijk contract behoeft niet noodzakelijkerwijs een schriffelijk document te zijn, maar veeleer een "gentlemen agreement", waarbij de betrokkenen de intentie tonen veranderingen te willen invoeren, bijvoorbeeld door hierin tijd en energie te steken en/of door deelname aan specifieke scholingsactiviteiten. In het kader van de stage-evaluatie moest afgesproken worden welke personen betrokken zouden worden bij de evaluatie en welke groep als overlegorgaan c.q. platform zou gaan fungeren. Om een zo groot mogelijk bereik te hebben zouden in deze groep alle relevante groeperingen vertegenwoordigd moeten zijn.

2. Het analyseren van de situatie. De betrokkenen moeten bereid zijn de bestaande situatie te analyseren. Dit betekent een vergelijking van de feitelijke situatie met de gewenste situatie. Op basis hiervan worden er knelpunten gesignaleerd, die veranderingen behoeven. Een dergelijke analyse vereist systematisch verzamelde evaluatiegegevens door derden, bijvoorbeeld onderzoeksinstituten, adviesbureaus, specifieke diensten en dergelijke. Er zijn diverse onderzoeken uitgevoerd, waarin nagegaan wordt welke factoren een adequaat gebruik van evaluatiegegevens bevorderen (Balla, Gibson \& Biggs, 1989; Cooley \& Bickel, 1986; Cousins \& Leitwood, 1986; Levinton \& Hughes, 1981; Stufflebeam et al., 1971). De bruikbaarheid neemt toe naarmate:

de betrokkenen de evaluatiegegevens als relevant zien. Dit betekent dat gegevens inhoudelijk voor betrokkenen van betekenis moeten zijn én beschikbaar moeten zijn op het moment dat de gebruiker hieraan behoefte heeft;

de communicatie fussen de evaluator(en) en de gebruiker(s) effectief is. Daarom moet er tussen de evaluator en gebruiker regelmatig contact zijn. De evaluator 
raakt hierdoor beter geïnormeerd over de behoeften van de gebruiker en is meer in staat hierop in te spelen. Directe communicatie, zonder tussenkomst van derden, is positief gecorreleerd met het gebruik van evaluatie-effecten;

de presentatie van de informatie duidelijk is. Een heldere rapportage, die aansluit bij het kennisniveau van de gebruikers, is onmisbaar. Bijvoorbeeld, het presenteren van geavanceerde statistische informatie verliest zijn functie wanneer de gebruiker deze niet kan interpreteren;

- de evaluatiegegevens geloofwaardig overkomen. De wijze waarop de gegevens verzameld en geïnterpreteerd zijn, moeten bij de gebruiker aannemelijk overkomen. Wanneer de gebruikers twijfels heeft over de betrouwbaarheid en validiteit van de evaluatie, vormt dit een reden om de gegevens niet te gebruiken; de gebruiker betrokken is bij het evaluatie-onderzoek. Wanneer de gebruiker vanaf het begin meer betrokken is bij de opzet en vitvoering van het onderzoek, neemt het gebruik van evaluatiegegevens toe.

3. Het voeren van een dialoog. De interpretatie van de verzamelde evaluatiegegevens moet zorgvuldig gebeuren en aanleiding zijn om te discussiëren over mogelijke oplossingen. Veranderingsvoorslellen zullen op hun voor-en nadelen bekeken moeten worden. Alle betrokken dienen deel te nemen aan deze discussie.

4. Het opstellen van een actieplan. De voorgaande stap dient te resulteren in een actieplan. Het actieplan dient een voorstel met veranderingen te bevatten en bij voorkeur in de vorm van concrete activiteiten.

5. Het regelmatig toetsen. Het uiteindelijk doel is dat acties uitmonden in verbeteringen. Het vastslellen van het resultaat is daarom essentieel. Afhankelijk van de effecten zullen wederom maatregelen getroffen moeten worden. Dit leidt tot de afsluiting van een nieuw contract en vervolgens zal de beschreven cyclus zich herhalen.

Evaluatie is een continue proces, waarbij de vijf stappen steeds opnieuw doorlopen moeten worden. In figuur 9 staan de stappen van het veranderingsproces schematisch weergegeven (Dalin, 1978). 


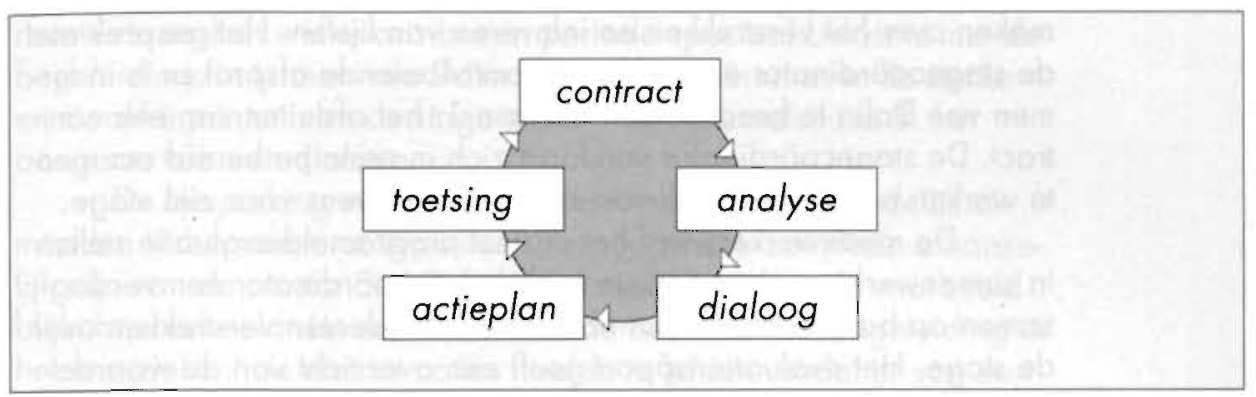

Stappen in het veranderingsproces volgens Dalin

Figuur 9

\subsection{Innovatie in de praktijk}

In samenspraak met de toenmalige onderwijscommissie is een actieplan opgesteld voor het optimaal aanwenden van evaluatiegegegevens. Hiertoe zijn een aantal activiteiten ondernomen, waarbij rekening is gehouden met de context van de stages. In 1988 vond tussen de stagecoördinator, de klinisch onderwijscoördinator en een medewerker van het project programma-valuatie een informatief gesprek plaats over het belang van stage-evaluatie. Aan de orde kwam het belang van een systematische evaluatie voor de kwaliteitshandhaving van stages. Het resultaat hiervan was dat alle coördinatoren zich bereid verklaarden de studenten te stimuleren de vragenlijsten in te vullen en om de gegevens te gebruiken voor de bijstelling van hun stage. Voorts werden met de stagecoördinatoren afspraken gemaakt over de wijze van rapportage en het tijdstip van rapportage. De gesprekken maakten duidelijk dat de informatieoverdracht niet beperkt moest blijven tot de stagecoördinatoren in het AZM maar zich ook moest richten op de coördinatoren van de diverse stages in de affiliatieziekenhuizen. Hieruit kwam de beslissing voort om de reeds bestaande planningsgroepen van elke stage als overlegorgaan te gebruiken. De contactpersonen van de diverse ziekenhuizen en de studenten waren daarin vertegenwoordigd. De stageplanningsgroep kwam gewoonlijk een à twee maal per jaar bij elkaar om de stage te bespreken (zie hoofdstuk 4). De stagecoördinatoren stemden toe om voortaan een vast agendapunt te reserveren voor de bespreking van evaluatiegegevens. De veronderstelling was dat het nut van een optimale respons door studenten én artsbegeleiders zou worden onderkend, als de resultaten van de evaluatie regelmatig aandacht zouden kriigen. Afgesproken werd om tijdens de eerst volgende bijeenkomst van de planningsgroep de opzet van de programma-evaluatie te introduceren en afspraken te 
maken over het verstrekken en inleveren van lijsten. Het gesprek met de stagecoördinator en de hieruit voortvloeiende afspraken is in termen van Dalin te beschouwen als fase 1: het afsluiten van een contract. De stagecoördinator verklaart zich in principe bereid om mee te werken aan het gebruik van evaluatiegegevens voor zijn stage.

De medewerkers van het project programma-evaluatie stellen in samenwerking met de klinisch onderwijscoördinator een verslag samen op basis van de informatie die de studenten verstrekken over de stage. Het evaluatierapport geeft een overzicht van de waarderingen van de sludenten voor de diverse aspecten van een slage. Hef verslag beschrijft zaken die verandering behoeven, bijvoorbeeld de introduclie is slecht georganiseerd of de student krijgt onvoldoende gelegenheid om patiënten zelfstandig te onderzoeken. Voorts maakt hel verslag melding van positieve aspecten van de stage, bijvoorbeeld de begeleiding die studenten ontvangen is van uitstekende kwaliteit, de studenten ontvangen regelmatig feedback op hun werkzaamheden of nabesprekingen vinden regelmatig plaats. Van zaken die onvoldoende scoren wordt een aandachtspunt gemaakt. De leden van de planningsgroep ontvangen allen een verslag. In termen van Dalin is het samenstellen van een verslag te beschouwen als fase 2: analyse van gegevens. De bedoeling is om de leden van de planningsgroep heldere informatie te verschaffen over de kwaliteit van de stage.

Vanaf 1989 volgt in de planningsgroepen een jaarlijkse presentatie en bespreking van de evaluatiegegevens. Tijdens deze bijeenkomst komen zwakke en sterke punten van de stage aan de orde. Hel is belangrijk om verklaringen te vinden voor zwakke punten. De oorzaken zullen mede bepalend zijn voor het soort maatregelen dal getroffen werd. Bijvoorbeeld in een ziekenhuis was de persoonsgebonden begeleiding van studenten met een onvoldoende beoordeeld. Bij navraag bleek dat een van de artsen lange tijd afwezig was geweest door ziekte, waardoor minder artsen dezelfde hoeveelheid werk moesten verrichten. Het gevolg was dat de begeleiding van studenten in de verdrukking raakte. Inmiddels had de betreffende arts zijn werk herval en was er als vanouds voldoende tijd beschikbaar voor de begeleiding. In een dergelijk geval was dus sprake van een tijdelijke probleemsituatie. Uiteraard was het onnodig om in dit geval maatregelen te treffen. Anders is het wanneer een lage waardering voor de begeleiding voortkomt uil structurele problemen. Bijvoorbeeld bij een andere stage die onvoldoende beoordeeld was voor de persoonsgebonden begeleiding, bleek dat er duidelijke afspraken ontbraken over wie verantwoordelijk was voor deze begeleiding. Dit vraagt om een beleid waarbij afspraken gemaakı worden over begeleidingstaken, bijvoorbeeld door een 
rooster te maken welke arts in een periode speciaal belast is met de begeleiding. In lermen van Dalin is het discussiëren over de sterke en zwakke punten van de stage te karakteriseren als fase 3: hel aangaan van een dialoog.

De bespreking van het evaluatieverslag moet uiteindelijk uitmonden in bepaalde actiepunten. Het soort actie zal mede afhankelijk zijn van de omstandigheid. Uit het reeds beschreven voorbeeld blijkt bijvoorbeeld dat een onvoldoende beoordeelde begeleiding in het ene ziekenhuis niet tot acties hoefde te leiden omdat er van een tijdelijk probleem sprake was en in een ander ziekenhuis leidł tot overleg met de diverse artsen op de afdeling. Bij het soort acties zal dus altijd rekening gehouden moeten worden met de context, mogelijkheden en omstandigheden. Actiepunten kunnen zoals in het voorbeeld stagegebonden zijn maar ook stage-overstijgend. Bijvoorbeeld in een stage zetten studenten vraagtekens bij de wijze waarop de mondelinge toetsing aan het einde van de stage plaatsvond. De zwaarte van de examens zou sterk athankelijk zijn van de betreffende examinator. Dit leidt tot acties om de inhoud van de toetsen nader te bekijken, de eindcijfers te analyseren op mogelijke verschillen tussen examinatoren en duidelijke richtlijnen te formuleren voor de inhoud van de toets. De stagecoördinator legt de gemaakte afspraken vast in de vorm van een besluitenlijst. In termen van Dalin is het noteren van actiepunten te beschouwen als fase 4 : het opstellen van actieplan.

De verwachting is dat acties een effect tot gevolg hebben. Om het resultaat vast te stellen, spreekt de planningsgroepen af om in de volgende bijeenkomst te kijken of de gemaakte afspraken zijn nagekomen en tot het gewenste resultaat hebben geleid. Bijvoorbeeld door vast te stellen of er inderdaad richtlijnen zijn geformuleerd om meer eenheid aan te brengen in de toetsing. Athankelijk van het resultaat van de acties worden nieuwe activiteiten afgesproken. De onderwijscoördinatiecommissie en de affiliatiecoördinatoren ontvangen alle evaluatieverslagen mel de bijbehorende besluitenlijst. Op deze manier raken ook de betrokkenen op beleidsniveau geinformeerd over de stand van zaken. Zij kunnen deze gegevens meenemen tijdens hel jaarlijkse overleg in de onderwijscommissie met de verschillende ziekenhuizen en/of gebruiken voor de bijstelling van het beleid (hoofdstuk 4). Desgewenst stuurt de onderwijscoördinatiecommissie een reactie naar de betreffende planningsgroep. In termen van Dalin is het controleren van afspraken te beschouwen als fase 5 : het regelmatig loetsen.

Deze procedure zorgt ervoor dat alle betrokkenen worden geïnformeerd en hun inbreng hebben bij de besluitvorming namelijk op het niveau van de stage via de planningsgroep, op het niveau 
van hel ziekenhuis via de onderwijscommissie en op het niveau van de faculteil via de onderwijscoördinatiecommissie. Elk niveau heeft ruimte voor zijn eigen inbreng en kan acties ondernemen die behoren bij hun niveau van werken, uitvoerend en/of beleidsmatig. $\mathrm{Er}$ vindt een voortdurende toetsing plaats door de effectiviteit van maatregelen te bekijken. In figuur 10 is de informatiestroom schematisch weergegeven.

Figuur 10 Informatiestroom evaluatiegegevens

Samenstelling van het concept-verslag door een medewerker van het project programmaevaluatie

Bespreking van het concept-verslag met de klinisch onderwijscoördinator

Vaststelling van het definitieve verslag

Mondelinge en schriftelijke rapportage aan de planningsgroep

Vaststelling van actiepunten en het samenstellen van de besluitenlijst

Toezending van het verslag en de besluitenlijst aan de affiliatiecoördinatoren en onderwijscommissie

Bespreking van het verslag in de onderwijscoördinatiecommissie en onderwijscommissie van de ziekenhuizen

Eventueel een reactie van de onderwijscoördinatiecommissie naar de planningsgroepen 
In deze manier van werken zijn de verschillende fasen, die Dalin (1978) in het veranderingsproces onderscheidt, te herkennen. Hiermede zijn voorwaarden gecreëerd om de stage-evaluatie in te voeren. De beschreven procedure is in 1988 ingevoerd. De stage-evaluatie is inmiddels een vast agendapunt bij planningsgroepsvergaderingen. Het aantal geretourneerde vragenlijsten is in de loop van de jaren zichtbaar geslegen: van $50 \%$ in 1988 naar $88 \%$ in 1990

Opgemerkt dient te worden dat in 1989 het affiliatiecontract met een aantal afdelingen van ziekenhuizen niet meer verlengd is. Op het moment dat de betreffende coördinatoren hiervan op de hoogte waren, stimuleerden zij de studenten niet meer om de vragenlijsten in te vullen. Immers de evaluatiegegevens konden toch niet meer vertaald worden in concrete acties voor hun stage. Dit drukte de respons bii enkele stages. In tabel 2 is een overzicht van het aantal geretourneerde vragenlijsten opgenomen. Een volgende vraag is op welke wijze de gegevens in praktijk een functie vervullen. Paragraaf. 7.4 beschrijft drie voorbeelden vit de praktijk.

Aantal geretourneerde vragenlijsten (1987.1990)

\begin{tabular}{|c|c|c|c|c|c|c|c|c|}
\hline & $\begin{array}{r}1987 \\
\text { freq }\end{array}$ & $\%$ & $\begin{array}{r}1988 \\
\text { freq }\end{array}$ & $\%$ & $\begin{array}{r}1989 \\
\text { freq }\end{array}$ & $\%$ & $\begin{array}{r}1990 \\
\text { freq }\end{array}$ & $\%$ \\
\hline Interne geneeskunde & 32 & 20 & 71 & 62 & 108 & 92 & 116 & 94 \\
\hline Chirurgie & 41 & 35 & 69 & 60 & 108 & 71 & 79 & 69 \\
\hline Gynaecologie & 95 & 84 & 119 & 92 & 119 & 96 & 116 & 90 \\
\hline Kindergeneeskunde & 99 & 82 & 98 & 77 & 108 & 92 & 113 & 90 \\
\hline Neurologie & * & * & 45 & 74 & 102 & 91 & 174 & 92 \\
\hline Oogheelkunde & * & * & 52 & 85 & 115 & 85 & 109 & 82 \\
\hline KNO & 70 & 61 & 100 & 79 & 104 & 83 & 124 & 98 \\
\hline Dermatologie & 57 & 46 & 79 & 63 & 102 & 84 & 100 & 84 \\
\hline Totaal & 394 & 50 & 633 & 73 & 866 & 87 & 871 & 88 \\
\hline
\end{tabular}




\subsection{Praktiiksituaties}

Aan de hand van drie praktijkvoorbeelden wordt geillustreerd op welke wijze de gegevens gebruikt worden. Studie 1 en 2 hebben betrekking op een stage in een affiliatieziekenhuis. Studie 3 heeft een ziekenhuisoverstijgend karakter.

\subsubsection{Studie 1: Dermatologie in een affiliatieziekenhuis}

\section{Doel}

Deze case-studie illustreert welke invloed een nieuwe stagecoördinator kan hebben op de kwaliteit van een co-assistentschap en op welke wijze dit in de evaluatiegegevens zichtbaar wordt.

\section{Situatieschets}

Het betreft hel co-assistentschap dermatologie in een affiliatieziekenhuis. De duur van deze slage is drie weken. Vanaf 1987 klaagden de studenten geregeld over het betreffende co-assistentschap. Alhoewel er binnen het co-assistentschap geen slechte sfeer heerste, was het leereffect volgens de studenten gering: de stage zou saai zijn, de activiteiten van de studenten zouden beperkt blijven tol "meelopen en meekijken met de artsen" en organisatorisch waren er de nodige kritiekpunten. De onderwijscoördinatiecommissie overwoog om het affiliatiecontract met betrekking tot dit co-assistentschap niet te continueren. Echter hel was bekend dat er op kort termijn een nieuwe stagecoördinator zou worden aangesteld. Dit was aanleiding voor de onderwijscoördinatiecommissie om de beslissing uit te stellen en te bekijken of er in de nabije toekomst verandering zou optreden. Eind 1988 werd een nieuwe coördinator benoemd. Met de coördinator heeft een gesprek plaatsgevonden waarin duidelijk werd ingegaan op de klachten van de stage. Hij deed de toezegging de begeleiding meer gestructureerd te laten plaatsvinden en organisatorisch een aantal veranderingen aan te zullen brengen.

\section{Evaluatiegegevens}

Sedert 1988 werden er regelmatig evaluatiegegevens verzameld over dit co-assistentschap. In tabel 3 staan de scores voor de onderscheiden domeinen vermeld. 


\begin{tabular}{|lcccc|}
\hline & $\begin{array}{r}1988 \\
\text { Gem }\end{array}$ & $\begin{array}{r}1989 \\
\text { Gem }\end{array}$ & $\begin{array}{r}1990 \\
\text { Gem }\end{array}$ & $\begin{array}{r}1991 \\
\text { Gem }\end{array}$ \\
\hline 1 Voorbereiding & & & & \\
\hline Stageboek & 2.7 & 3.5 & 3.7 & 3.4 \\
\hline Persoonsgebonden begeleiding & 3.4 & 3.4 & 4.2 & 3.9 \\
\hline 4 Begeleiding medisch-technisch & 2.7 & 4.4 & 4.8 & 4.8 \\
\hline 5 Aandacht patiënt en context & 2.1 & 2.6 & 4.4 & 4.5 \\
\hline Onderwijsactiviteiten & - & 2.3 & 3.6 & 3.5 \\
\hline 7anbod patiëntproblemen & 4.1 & 4.6 & 4.6 & 3.2 \\
\hline 8atiëntgebonden leersituaties & 3.8 & 4.6 & 4.3 & 4.9 \\
\hline 9 Polikliniek & 2.9 & 3.6 & 4.8 & 5.0 \\
\hline 10 Studiefaciliteiten & 4.1 & 3.6 & 4.4 & 4.4 \\
\hline 11 Stagebeoordeling & 3.8 & 4.7 & 4.8 & 4.6 \\
\hline 12 Gelegenheid tot zelfstudie & 4.1 & 4.1 & 4.4 & 4.7 \\
\hline 13 Algemeen oordeel & 3.3 & 3.8 & 4.2 & 4.4 \\
\hline
\end{tabular}

Domeinscores (1-5) voor de stage dermatologie in een affiliatiezie Tabel 3 kenhuis (periode 1988-1991)

In 1988 zijn de beoordelingsgegevens voor een aantal aspecten laag; ook in vergelijking met de stages in andere ziekenhuizen Deze gegevens zijn een afspiegeling van de geruchten over deze stage. In 1989 is er reeds over de hele linie een duidelijke stijging in de waardering waarneembaar voor de betreffende stage. De waardering voor domein 2 "het stageboek", is in 1989 constant gebleven. Dit valt te verklaren omdat het stageboek niet veranderd was. In 1989 heeft het betreffende ziekenhuis meer poli-ruimte beschikbaar gekregen. Dit heeft een stijging tot gevolg op domein 9 "polikliniek". In 1990 is gedurende het hele jaar met de uitgebreide poli-ruimte gewerkt en dit vindt zijn weerslag in de score op domein 9. In 1990 stijgt de waardering over de hele linie. Inmiddels heeft het stageboek ook aanpassingen ondergaan en dit komt ook lot viting in de score van domein 2. Het is opmerkelijk dat de score voor het domein 1 "voorbereiding", bij de komst van de nieuwe stagecoördinator stijgt, terwijl er in het curriculum van jaar $1 \mathrm{t} / \mathrm{m} 4$ geen wezenlijke veranderingen hebben plaatsgevonden. Op de overige stageplaatsen is er geen stijging ten aanzien van de voorbereiding. De stagecoördinator geeft aan dat hij het als een gegeven beschouwd dat studenten weinig voorkennis hebben, maar tijdens 
de begeleiding hiermee rekening houdt en deze afstemt op de doelgroep. Momenteel behoort deze stage tot de beste van alle klinische co-assistentschappen.

\section{Conclusie}

Uit de evaluatiegegevens van deze praktijksituatie blijkt dat de stagecoördinator een sterke invloed kan hebben op de kwaliteit van een co-assistentschap. Voorts wordt duidelijk geillustreerd dat de onderscheiden domeinen duidelijk manipuleerbaar zijn en door inzet van in dit geval de stagecoördinator geoptimaliseerd kunnen worden. De evaluatiegegevens laten duidelijk het effect van getroffen maatregelen zien. Ook blijkt dat de begeleider een "compense rende" invloed kan uitoefenen in geval de voorkennis van studenten laag is.

\subsubsection{Studie 2: Kindergeneeskunde in een affiliatie- ziekenhuis}

\section{Doel}

Deze studie illustreert op welke wijze evaluatiegegevens gebruikt kunnen worden om een sterkte-zwakte-analyse van een co-assistentschap te maken.

\section{Situatieschets}

Hel betreft het co-assistentschap kindergeneeskunde in een affiliatieziekenhuis. De duur van deze stage bedraagt zes weken. Vanaf 1985 waren er in de "wandelgangen" geluiden van studenten te horen over de kwaliteit van het betreffende co-assistentschap. Het co-assistentschap zou erg passief ziijn en de sludenten weinig satisfactie geven mede doordat de studenten niet als eerste de anamnese bij patiënten mochten afnemen en het onderzoek verrichten. Empirische gegevens die afkomstig zijn van een representatieve groep studenten kunnen meer inzichl geven in de ernst en omvang van de problemen. $V$ an de betreffende stage werd daarom een profiel gemaakt.

\section{Evaluatiegegegevens}

Met behulp van profielanalyse werd getracht duidelijk te krijgen op welke fronten de problemen lagen en werd gepoogd meer inzicht te krijgen in de ernst van de problemen. Tevens werd nagegaan in hoeverre dit co-assistentschap afwijkend scoorde van de stages binnen dezelfde discipline. In figuur 11 is het profiel van de betreffende stage weergegeven en is de gemiddelde score (doorlopende lijn] van andere kindergeneeskundige stages weergegeven. 


\section{Domein}

Algemeen oordeel

Zelfstudie

Stagebeoordeling

Studiefaciliteiten

Polikliniek

Patiëntgebonden leersituaties

Aanbod patiëntproblemen

Onderwijsactiviteiten

Aandacht patiënt en context

Begel. medisch-rechnisch

Persoonsgebonden begel.

Stageboek

Voorbereiding

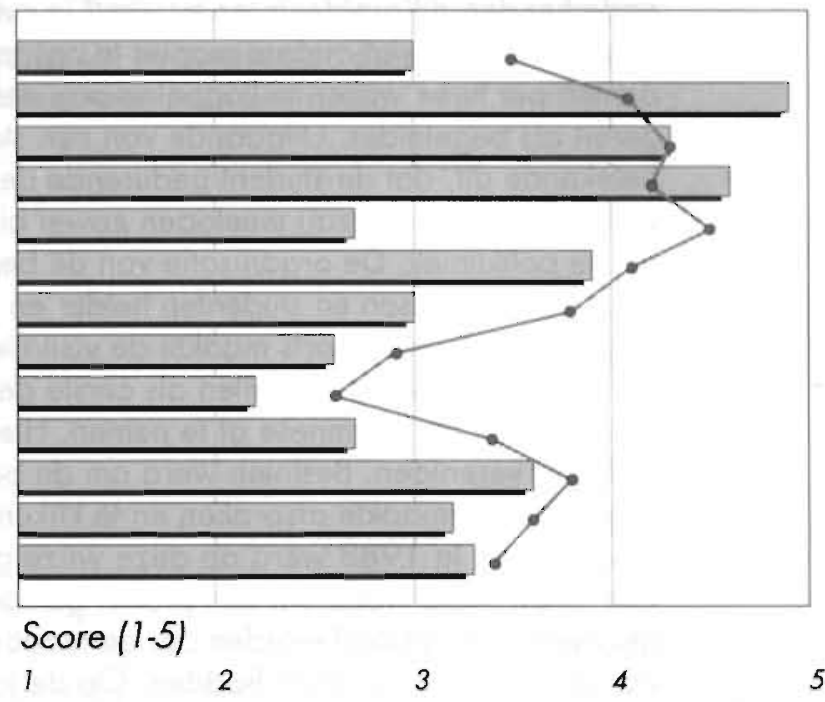

Profiel van de stage kindergeneeskunde in een affiliatieziekenhuis (data 1987)

Het profiel laat zien dat deze stage in vergelijking met de andere stages binnen dezelfde disciplines over de hele linie relatief lager scoort. De domeinen: begeleiding medisch-technisch handelen, oandacht gericht op patiënt en context, onderwijsactiviteiten, aanbod patiëntproblemen, polikliniek en algemeen oordeel, scoren zowel absoluut als relatief laag. De lage waardering voor deze stage was aanleiding voor onderwijscoördinatiecommissie om een "visitatiecommissie" in te stellen, die de taak kreeg samen met de verantwoordelijke kinderartsen van het betreffende ziekenhuis te bekijken hoe de stage verbeterd kon worden. Tijdens het gesprek zijn de problemen van het co-assistentschap uitvoerig met de betreffende coördinaior besproken en zijn afspraken gemaakt ten aanzien van moge lijke veranderingen. Er kwam naar voren dat er geen duidelijke afspraken waren over de begeleiding, welke daardoor voor studen. ten waarschijnlijk erg ondoorzichtig was. Er waren drie artsen op de afdeling werkzaam, waarmee de studenten konden "meelopen". Over de wijze waarop dat diende te gebeuren, waren geen strikte afspraken gemaakt. Het gevolg was dat de begeleiders zich niet uitdrukkelijk verantwoordelijk voelden voor een bepaalde student en 
de studenten niet wisten tot wie ze zich moesten en konden wenden. Dit resulteerde in een inadequate manier van begeleiden. De artsen onderkenden dit probleem en er werd in overleg afgesproken om de begeleiding op een andere manier te organiseren namelijk door studenten per twee weken te koppelen aan een vaste arts, die zou fungeren als begeleider. Uitgaande van een stageduur van 6 weken betekende dit, dat de student gedurende de stageperiode met drie verschillende artsen zou meelopen zowel bij visites op de afdeling als de polikliniek. De organisatie van de begeleiding werd daardoor voor de artsen en studenten helder en zou de kwaliteit van de stage bevorderen. Voorts maakte de visitatiecommissie kenbaar dat het gewenst was dat studenten als eerste de nieuwe patiënten zouden zien om de anamnese af te nemen. Hiermee konden de artsen zich niet verenigen. Besloten werd om de begeleiding te realiseren volgens de gemaakte afspraken en te kijken wat de effecten hiervan zouden zijn. In 1988 werd op deze wijze gewerkt. Aan het einde van 1988 werd wederom een profiel gemaakt. Op basis van deze gegevens kan gesteld worden dat de maatregelen op het gebied van de begeleiding effect hadden. Op de jaarlijkse bijeenkomst van de planningsgroep werd het betreffende ziekenhuis medegedeeld dat de waardering voor dit co-assistentschap een stijgende lijn vertoonde en werd besloten deze manier van begeleiden te continueren (zie tabel 4). Een jaar later, in 1989, is er een daling van de scores waar te nemen. Domein 2 "stageboek", domein 5 "aandacht patiënt en context", domein 6 "onderwijsactiviteiten" en domein 9 "polikliniek" scoren nog steeds laag. Het blijkt dat de extra aandacht die aanvankelijk gegeven werd aan de begeleiding weer gedeeltelijk is weggezakt en er dus geen sprake is van incorporatie van de vernieuwing. Deze gegevens vormden aanleiding om opnieuw een gesprek te arrangeren. Hieraan werd deelgenomen door de kinderartsen (2 van de 3), de stagecoördinator kindergeneeskunde, de klinisch onderwijscoördinator en de onderwijskundige van het project programma-evaluatie. Tijdens dit gesprek bleek dat de aanvankelijk genomen maarregelen ten aanzien van de begeleiding verwaterd waren en de begeleiding wederom ondoorzichtig was. Het patiëntenaanbod was nog steeds aan de lage kant. Dit leidde opnieuw tot afspraken over de begeleiding en het vitdrukkelijke verzoek om studenten bij nieuwe patiënten als eerste de anamnese en het lichamelijk onderzoek te laten verrichten en de afspraak dat er gerichte patiëntbesprekingen gepland zouden worden die uit zouden uitmonden in suggesties voor zelfstudie. Na zes maanden blijkt er geen vooruitgang te zijn. De betreffende opleiders geven aan het affiliatiecontract met ingang van 1991 niet meer te willen verlengen, omdat zij zich niet kunnen vinden in de voorwaarden die de 
medische faculteit Maastricht stelt - zoals studenten als eerste bij nieuwe patiënten de anamnese te laten afnemen en het lichamelijk onderzoek te laten verrichten. Dit betekent dat het affiliatiecontract in januari 1991 beëindigd is. De gegevens van de programma-evaluatie vormen mede een basis voor deze beslissing.

Domeinscores (1-5) voor de stage kindergeneeskunde in een affiliatieziekenhuis (periode 1987-1990)

\begin{tabular}{|c|c|c|c|c|}
\hline & $\begin{array}{c}1987 \\
\text { Gem }\end{array}$ & $\begin{array}{r}1988 \\
\text { Gem }\end{array}$ & $\begin{array}{r}1989 \\
\text { Gem }\end{array}$ & $\begin{array}{r}1990 \\
\text { Gem }\end{array}$ \\
\hline 1 Voorbereiding & 3.3 & 3.7 & 3.6 & 3.7 \\
\hline 2 Stageboek & 3.2 & 3.5 & 2.9 & 3.5 \\
\hline 3 Persoonsgebonden begeleiding & 3.5 & 4.1 & 3.5 & 3.5 \\
\hline 4 Begeleiding medisch-technisch & 2.7 & 3.3 & 3.1 & 2.6 \\
\hline 5 Aandacht patiënt en context & 2.2 & 2.5 & 2.4 & 2.2 \\
\hline 6 Onderwijsactiviteiten & 2.6 & 2.8 & 2.7 & 3.7 \\
\hline 7 Aanbod patiëntproblemen & 3.0 & 3.7 & 3.0 & 2.9 \\
\hline 8 Patiëntgebonden leersituaties & 3.9 & 3.9 & 3.8 & 3.2 \\
\hline 9 Polikliniek & 2.7 & 2.7 & 2.6 & 2.4 \\
\hline 10 Studiefaciliteiten & 4.6 & 4.6 & 4.5 & 4.6 \\
\hline 11 Stagebeoordeling & 4.3 & 4.2 & 4.3 & 4.2 \\
\hline 12 Gelegenheid tot zelfstudie & 4.9 & 4.7 & 4.9 & 4.7 \\
\hline 13 Algemeen oordeel & 3.0 & 3.6 & 3.2 & 3.3 \\
\hline
\end{tabular}




\section{Conclusie}

Dit praktijkvoorbeeld laat zien dat in eerste instantie sprake is van voorvitgang op aspecten waar duidelijk verandering is aangebracht. Het effect heeft slechts een tijdelijk karakler. Voorts wordt duidelijk dat uitgangspunten van de faculteit waar de artsen van de stageplaats niet volledig achterstaan niet vitmonden in acties. Hiermee wordt geillustreerd dat alle betrokkenen het belang van veranderingen moeten onderschrijven.

\subsubsection{Studie 3: Voorbereiding op de stage}

\section{Doel}

Het doel van deze case-studie was na te gaan voor welke co-assistentschappen studenten onvoldoende zijn voorbereid op het gebied van theorie en/of vaardigheden.

\section{Situatieschets}

De bedoeling is dat de eerste fase en de tweede fase van de opleiding inhoudelijk op elkaar aansluiten. De studenten wordt aan het einde van de stage gevraagd aan te geven in hoeverre ze zich op het gebied van kennis en vaardigheden voldoende voorbereid voelden op een co-assistentschap. In tabel 5 is de mate van voorbereiding voor de stage aan de hand van betreffende domeinscores weergegeven.

Tabel 5 Domeinscore voor voorbereiding stages (periode 1987-1990)

\begin{tabular}{|c|c|c|c|c|}
\hline 20 & $\begin{array}{r}1987 \\
\text { Gem }\end{array}$ & $\begin{array}{c}1988 \\
\mathrm{Gem}\end{array}$ & $\begin{array}{c}1989 \\
\text { Gem }\end{array}$ & $\begin{array}{r}1990 \\
\text { Gem }\end{array}$ \\
\hline Interne geneeskunde & 3.6 & 3.7 & 3.7 & 3.5 \\
\hline Chirurgie & 3.9 & 3.9 & 3.7 & 3.6 \\
\hline Gynaecologie/obstetrie & * & * & 3.7 & 3.6 \\
\hline Kindergeneeskunde & 3.5 & 3.5 & 3.6 & 3.6 \\
\hline Neurologie & ** & 3.4 & 3.2 & 3.2 \\
\hline Oogheelkunde & ** & 3.1 & 3.2 & 3.2 \\
\hline KNO & 3.4 & 3.3 & 3.4 & 3.4 \\
\hline Dermatologie & 3.0 & 3.1 & 3.1 & 3.2 \\
\hline 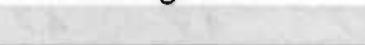 & & & & 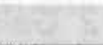 \\
\hline
\end{tabular}


Uit tabel 5 blijkt dat de studenten zich met name voor de kortdurende co-assistentschappen - neurologie, oogheelkunde, KNO en dermatologie - het minst goed voorbereid voelden. Het domein "voorbereiding" bestaat uit twee items: voorbereiding op het gebied van kennis en voorbereiding op hel gebied van vaardigheden. In tabel 6 zijn de resultaten uitgesplitst voor beide items.

Itemscores voor voorbereiding op het gebied van vaardigheden (V) en voorbereiding op het gebied van kennis (K)

\begin{tabular}{|c|c|c|c|c|c|c|c|c|}
\hline & \multicolumn{2}{|c|}{1987} & \multicolumn{2}{|c|}{1988} & \multicolumn{2}{|c|}{1989} & \multicolumn{2}{|c|}{1990} \\
\hline & $V$ & $K$ & V & K & V & $k$ & $V$ & $K$ \\
\hline Interne geneeskunde & 4.0 & 3.2 & 4.1 & 3.3 & 4.0 & 3.4 & 3.8 & 3.2 \\
\hline Chirurgie & 4.2 & 3.6 & 4.1 & 3.6 & 4.0 & 3.4 & 3.9 & 3.4 \\
\hline Gynaecologie/obstetrie & * & 3.7 & * & 3.8 & 3.8 & 3.5 & 3.9 & 3.4 \\
\hline Kindergeneeskunde & 4.0 & 3.0 & 4.0 & 3.1 & 4.0 & 3.1 & 4.0 & 3.2 \\
\hline Neurologie & ** & ** & 4.1 & 2.7 & 3.8 & 2.6 & 3.7 & 2.8 \\
\hline Oogheelkunde & ** & ** & 3.8 & 2.4 & 3.9 & 2.4 & 3.6 & 2.8 \\
\hline KNO & 4.0 & 2.8 & 3.9 & 2.7 & 3.9 & 2.8 & 3.9 & 3.0 \\
\hline Dermatologie & 4.0 & 2.1 & 4.1 & 2.2 & 3.9 & 2.2 & 3.8 & 2.6 \\
\hline
\end{tabular}


Uitsplitsing op itemniveau laat zien dat er voor bepaalde stages een aanmerkelijke discrepantie is tussen de scores op beide items. Over het geheel genomen voelen studenten zich op het gebied van de vaardigheden redelijk goed voorbereid. Ten aanzien van kennis ligt dit anders. Deze gegevens dienen als signaal naar de onderwijscoördinatiecommissie om het programma in jaar $1 \mathrm{l} / \mathrm{m} 4$ naar inhoud te bekijken en na te gaan of bepaalde disciplines ten onrechte onderbelicht zijn. Met name de voorbereiding voor de stage dermatologie laat te wensen over. Nadere analyse van het curriculum van de eerste vier studiejaren (Snellen-Balendong, 1984) laat zien dat er op dit terrein weinig leerstof aan de orde komt. In het academiejaar $1988 / 1989$ is een grootscheepse vernieuwing van het curriculum gestart (Nota Rode draad III, IV, 1987, 1989) en besloten is om aan het vakgebied dermatologie extra aandacht te besteden. In studiejaar 3 is een blok geplaatst getiteld "Het binnenste van buiten" (Hulsmans e.a., 1989) waarin dermatologie centraal aan de orde komt. Het blok is in het studiejaar 1990/1991 gestart en dit zou betekenen dat vanaf het studiejaar 1993/1994 het co-assistentschap dermatologie geconfronteerd zal worden met studenten die aanzienlijk beler voorbereid zijn op die stage. Uiteraard zal dit een stijging van de scores op domein 1 "voorbereiding" teweeg moeten brengen.

\section{Conclusie}

Deze manier laat zien dat evaluatiegegevens mede gebruikt kunnen worden om hiaten in het curriculum op te sporen. Uiteraard zal niet alleen op stage-evaluatiegegevens beslist moeten worden een studieprogramma te wijzigen maar zullen er aanvullende gegevens verzameld moeten worden.

\subsection{Samenvatting}

In dit hoofdstuk is een beschrijving gegeven van maatregelen die zijn getroffen om de evaluatie een plaats te geven binnen de stages. Om een adequaat gebruik van gegevens te bevorderen zijn een aantal randvoorwaarden geschapen. Hierbij is zoveel mogelijk rekening gehouden met factoren waarvan bekend is dat ze van invloed zijn op het slagen van veranderingen. Tenslotte is aan de hand van een drie praktijkvoorbeelden geillustreerd op welke wijze evaluatiegegevens een functie kunnen vervullen in de praktijk. 


\section{Validiteit van het instrument}

In het vorige hoofdstuk is de constructie van een instrument ten behoeve van de meting van de kwaliteit van stages beschreven. Van meetinstrumenten wordt de nodige validiteit en betrouwbaarheid vereist. In dit hoofdstuk staat de validiteit van de vragenliist centraal. In paragraaf 8.1 wordt een inleiding gegeven op de validiteit. In paragraaf 8.2 volgt een beschrijving van een studie die uitgevoerd is naar de structuur van de vragenlijst. Er wordt nagegaan of de op inhoudelijke en pragmatische gronden a-priori gespecificeerde multidimensionale structuur in de vragenlijst ook in de verzamelde data tot uitdrukking komt. Hiervoor wordt gebruik gemaakt van toetsende factoranalyse. In paragraaf $8.3 \mathrm{komt}$ aan de orde in hoeverre het instrument eenzelfde latente structuur vertoont bij afname over verschillende jaren. Dit geeft een indicatie omtrent de stabiliteit van de onderscheiden domeinen. Om hierover een uitspraak te kunnen doen worden de correlatiematrices van 1989 en 1990 op invariantie getoetst. Paragraaf 8.4 geeft een samenvatting.

\subsection{Inleiding validiteit}

Een van de eisen waaraan een meetinstrument dient te voldoen is dat het valide is. Validiteit verwijst naar de mate waarin een instrument aan zijn doel beantwoordt (Drenth, 1985). In deze algemene definitie wordt gerefereerd naar de beoogde doelstelling van het instrument: een instrument kan valide zijn voor een bepaald doel en niet voor een ander doel. Afhankelijk van het doel van een instrument zal het begrip validiteit verschillend geoperationaliseerd worden. Uit de koppeling van de validiteit aan het doel van het meten vloeit tevens een relevant indelingsprincipe in soorten validiteiten voort.

Gewoonlijk onderscheidt men drie typen validiteiten: predictieve validiteit, inhoudsvaliditeit en constructvaliditeit. Predictieve georiënteerde validiteiten zijn gericht op het doen van uitspraken of met een instrument correcte voorspellingen gedaan kunnen. De feiten kunnen in de toekomst liggen, of in het heden, of zelfs in het ver- 
leden. Het gaal hier steeds om een relatie tussen een (test)score met een criteriumvariabele. Een instrument is meer valide naarmate het sterker correleerl met een extern criterium, bijvoorbeeld studieprestaties. Dit type validiteit valt of staat met de kwaliteit en relevantie van het criterium. Welke eigenschap her instrument meet is van ondergeschikt belang. Dit in tegenstelling bij de volgende twee groepen validiteiten, waarbij het te meten begrip zelf van essentieel belang is en men bij de validering uitspraken wil doen over de inhoud ofwel het achterliggende construct van het instrument. Inhoudsvaliditeiten zijn bedoeld om aan te geven of het instrument op een adequate wijze het universum van de meting representeert. De inhouds. validiteit wordt veelal vastgesteld aan de hand van oordelen van deskundigen over de inhoud van het instrument in relatie mel datgene wat men beoogt te meten. Drenth (1985) stelt dat bij deze methode een zwaar appèl wordt gedaan op het subjectieve oordeel van deskundigen en vraagt zich af of de inhoudsvaliditeit als een aspect van de validiteit beschouwd mag worden. Constructvaliditeiten zijn bedoeld om uitspraken te doen over het meten van de trek of eigenschap die van belang geacht wordt. De vraag is of de test de bedoelde eigenschap meet. Om de constructvaliditeit te bepalen moeten de theoretische relaties tussen de variabelen gespecificeerd worden. Deze relaties tussen de variabelen worden empirisch onderzocht. Op basis hiervan stelt men vast of de onderzoeksresultaten de hypotheses bevestigen of ermee in strijd zijn (Cronbach \& Meehl, 1955). Binnen elk type kunnen diverse valideringsmethoden onderscheiden worden. Van Berkel (1984) heeft een inventarisatie gemaakt van verschillende te onderscheiden valideringsmethoden die te onderkennen zijn. Hij komt tot ruim 70 manieren om instrumenten te valideren.

In het licht van de doelstellingen van het in deze studie geconstrueerde instrument zal vastgesteld moeten worden welk(e) soort(en) validiteit en methoden relevant zijn. Het doel is als volgt geformuleerd: "Het instrument is een hulpmiddel om een valide vitspraak te doen over sterke en zwakke punten van de stages met de bedoeling betrokkenen van adequate feedback te voorzien ". Uit deze doelstelling volgi dat de inhoudsvaliditeit en de constructvaliditeit van essentieel belang zijn. De interpretatie van scores is direct gerelateerd aan de betekenisvolheid van de inhoud, opdat deze vertaald kunnen worden naar maatregelen in de praktijk. Predictieve validiteiten zijn in dit kader van minder belang, omdat het instrument niet pretendeert voorspellingen te doen. Aan de inhoudsvaliditeit is reeds in hoofdstuk 5 de nodige aandacht besteed. De inhoud van de vragenlijst is tot stand gekomen enerzijds op basis van literatuurstudies naar kenmerken van stages en anderzijds in nauw over- 
leg met inhoudsdeskundige stagecoördinatoren. Op basis hiervan is reeds een indicatie verkregen van de inhoudsvaliditeit. De construckvaliditeit vormt het onderwerp van de hiernavolgende studies.

\subsection{Studie 4: Constructraliditeit}

\subsubsection{Inleiding}

Constructvaliditeit verwijst naar de mate waarin het meetinstrument in staat is een achterliggende trek of eigenschap te meten. De beoordelingslijst voor stage-evaluatie is een hulpmiddel bij het doen van uitspraken over de kwaliteit van stages. Kwaliteit is gedefinieerd in termen van voorwaarden waaraan een stageplaats moet voldoen. Deze voorwaarden zijn omschreven in 14 benoembare domeinen, geoperationaliseerd in items (hoofdstuk 5). Studenten kennen aan deze items een waarde-oordeel toe. Het begrip kwaliteit is daardoor meetbaar gemaakt. Deze domeinen zijn zowel vanuit theoretisch als pragmatisch perspectief zinvol, theoretisch omdat zij refereren aan de wijze waarop het begrip kwaliteit is geoperationaliseerd op basis van literatuurstudies en de inbreng van deskundigen, pragmatisch omdat zij verwijzen naar de praktische bruikbaarheid van de operationalisering in de zin dat de domeinen dusdanig zijn gedefinieerd dat ze herkenbaar, relevant en manipuleerbaar zijn. Hieruit volgt dat er duidelijke verwachtingen geformuleerd kunnen worden over de structuur van de vragenlijst. Interessant is om na te gaan in hoeverre deze veronderstelde theoretisch-pragmatische factorstructuur eveneens empirisch waarneembaar is. Een manier om hierover vitspraken te doen is het gebruik van toetsende factoranalyses [Goldstein \& Hersen, 1984). Aan toetsende factoranalyses ligt de assumptie ten grondslag dat er vooraf duidelijke verwachtingen geformuleerd zijn over achterliggende structuren. Dit in tegenstelling tol exploratieve factoranalyses, waarbii op voorhand geen duidelijk gedachten gevormd ziin over de structuur (Kim \& Mueller, 1982).

Een veel gebruikte methode voor toetsende factoranalyse is de LISREL- methode (Jöreskog \& Sörbom, 1978). Hiermee kan nagegaan worden in hoeverre de gepostuleerde structuur afwijkt van de empirisch gevonden structuur. In een dergelijke procedure wordt volgens een a-priori gepostuleerd model een correlatiematrix geproduceerd. Het l.ISREL-programma toetst in hoeverre de correlaties russen geobserveerde variabelen kunnen worden gereproduceerd door het a-priori gespecificeerd model. Het produceren van een correlatiematrix veronderstelt een specificatie van drie matrices: de LAMBDA. $\mathrm{X}$ matrix die de factorladingen bevat, de $\mathrm{PHI}$ matrix die de correlaties tussen de factoren bevat, en de THETA-DELTA matrix die de 
unieke varianties ofwel de meeffouten van ieder geobserveerde variabelen bevat. Parameterschattingen uitgevoerd met de maximum-likelyhoodmethode leveren een statistic op die een $\mathrm{CHI}-\mathrm{kwad}$ raat-verdelingsvorm heeft. $\mathrm{Bij}$ het maken van een afweging of een model past bij de data zijn de volgende gegevens van belang (Saris \& Stronkhorst, 1984):

De CHI-kwadraat waarde $\left(\chi^{2}\right)$. Deze geeft de passing van het model weer bij de geobserveerde data met een bepaalde overschrijdingskans (p). Normaliter worden modellen waarbij de ratio $\left(\chi^{2} / \mathrm{df}\right)$ groter is dan 2 als niet passend beschouwd; De grootte van de residuen. De index die hiervoor in aanmer. king komt is de Root Mean Squared Residual (RMSR). De RMSR is de wortel uit het gemiddelde van de gekwadrateerde residuen. De RMSR is een maat voor de gemiddelde grootte van de niet door het model verklaarde residuen. Hoe kleiner de waarde RMSR, hoe beter de passing van het model. De RMSR benadert 0 wanneer de correspondentie tussen model en werkelijkheid bijna perfect is. Als vuistregel wordt vaak gehanteerd dat RMSR-waarden kleiner dan .07 op een goede passing duiden;

De Goodness-of-Fit Index (GFI) en de gecorrigeerde versie ervan, de zogenaamde Adjusted Goodness-of-Fit-Index (AGFI). Een GFI respectievelijk AGFI zijn verbijzonderingen van de RMSR. Het verschil bestaat hierin dat in de gecorrigeerde GFI rekening wordt gehouden met het aantal te schatten parameters (vrijheidsgraden). GFI kan variëren tussen 0 en 1. Een goed passend model heeft een GFI-waarde die de optimaal te bereiken grens van 1 nadert. In de regel streeft men naar waarden groter dan 80 .

$\mathrm{De} \mathrm{CHI}-\mathrm{kwadraat}$ is afhankelijk van de grootte van de steekproef. $\mathrm{Bij}$ grote steekproeven kunnen modellen met een redelijke fit toch significant van de geobserveerde data afwijken. Als aanvulling op de $\chi^{2}$ is het zinvol om een alternatieve "fit-index" te berekenen die steekproefonathankelijk is. Een bruikbare index hiervoor is de Tucker-Lewis index: rho. Als de waarden van rho groter zijn dan .90 dan is dit een aanwijzing dat de empirische data overeenstemmen met het gepostuleerde model (Marsh \& Hocevar, 1983). Wanneer op basis van bovenstaande maten wordt geconcludeerd dat de gepostuleerde en geobserveerde malrix significant van elkaar afwijken dan moet worden aangenomen dat het model onjuist is gespecificeerd en moel worden verworpen. Voor een uitgebreide bespreking van de LISREL-procedure wordt verwezen naar Jöreskog en Sörbom (1978) en naar Saris en Stronkhorst (1984). 


\subsubsection{Methode}

Het programma LISREL versie V (Jöreskog \& Sörbom, 1978) is gebruikt om na te gaan of de gekozen indeling in domeinen op empirische gronden is te rechtvaardigen. $\mathrm{Er}$ is gebruik gemaakt van de data die in 1989 bij de studenten op itemniveau verzameld zijn. In de analyses zijn uitsluitend de items betrokken die bij alle stages deel vitmaakten van de vragenlijst. De stagegebonden vragen zijn achterwege gelaten. Dit betekent dat er de beschikking was over 875 bruikbare waarnemingen. In hoofdstuk 5 is aangegeven dat de vragen lijst 14 domeinen kent. In deze analyse worden drie domeinen niet meegenomen. Het betreft:

het domein tijdsbesteding omdal dit open vragen betreft. De studenten vermelden het aantal uren dat ze op de stageplaats aanwezig zijn en het aantal uren dat zij aan individuele studie besteedden en het aantal uren dat in beslag genomen werd door niet-leerzame werkzaamheden;

het domein onderwijsactiviteiten omdat een grote groep studenten de hiertoe behorende vragen niet beantwoord had. Onderwijsbijeenkomsten ontbraken op diverse stageplaatsen; het domein zelfstudie omdat dit bestond uit één item en een grote non-respons vertoonde.

Voorts zijn er geen items in de analyses betrokken die een beschrijvend oordeel van de studenten over de stage vragen en kwalitatieve informatie leveren. Het betreft de vragen: "welke zaken zou je in de stage veranderd willen zien?" en "welke aspecten van de stage vond je erg goed?". Hieruit volgt dat er 11 domeinen zijn betrokken in de toetsende factoranalyse. De analyse is uitgevoerd op de correlatiematrix van 4.7 items, waarbij elk domein minimaal 2 items en maximaal 12 items bevat. In tabel 7 staan de domeinen met het bijbehorend aantal items vemeld. Een uitgebreide toelichting bij de domeinen is gegeven in hoofdstuk 5 . 
1 Voorbereiding op de stage

2 Stageboek

3 Persoonsgebonden begeleiding

4 Begeleiding medisch-technisch

5 Aandacht patiënt en context

6 Onderwijsactiviteiten

7 Aanbod patiëntproblemen

8 Patiëntgebonden leersituaties

9 Polikliniek

10 Studiefaciliteiten

11 Stagebeoordeling

12 Zelfstudie

13 Algemeen oordeel

14 Tijdsbesteding

Totaal

* niet meegenomen in de factoranalyse

Tabel 7 Overzicht van de domeinen en het aantal items

\section{Getoetste modellen}

Op inhoudelijke gronden zijn er sterke motieven om voor een indeling in 11 domeinen te kiezen. De eerste vraag was dan ook in hoeverre deze indeling ook op empirische gronden te rechtvaardigen is. Daarnaast is het interessant om te onderzoeken in hoeverre andere indelingen eveneens acceptabel zouden zijn. Daarom is gekozen voor een enigszins exploratieve benadering, waarbij uitgegaan werd van de correlatiematrix van de 11 domeinscores. Nagegaan werd in hoeverre deze aanwijzingen bevatte om bepaalde domeinen te clusteren. Eventueel zou dit een reden kunnen zijn om domeinen alsnog samen te voegen. De correlatiematrix van de items is als input gebruikt, waarbij de indeling in 11 domeinen als vertrekpunt voor de LISREL-procedure werd gebruikt. Vervolgens is nagegaan in hoeverre andere indelingen eveneens acceptabel zouden kunnen zijn. Daarom is een correlatiematrix van de gemiddelde domeinscores gemaakt, waarbij uitgegaan is van de gedachte dat domeinen die hoog met elkaar correleren, mogelijkerwijs als één en hetzelfde domein beschouwd zouden kunnen worden. In tabel 8 is de correlatiematrix van de domeinscores weergegeven. 
domeinen

$\begin{array}{lllllllllll}1 & 2 & 3 & 4 & 5 & 7 & 8 & 9 & 10 & 11 & 13\end{array}$

1 Voorbereiding

2 Stageboek $\quad .15$

3 Persoonsgebonden begeleiding .07 .42

4 Begeleiding medisch-technisch .17 .35 .63

5 Aandacht patiënt en context $\quad .20 .36 .50 .70$

7 Aanbod patiëntproblemen $\quad .18 .22 .40 .37 .26$

8 Patiëntgebonden leersituaties $\quad .09 .17 .37 .38 .32 .16$

9 Polikliniek $\quad 06.21 .22 .18 .11 .20 .08$

10 Studiefaciliteiten $\quad .14 .20 .24 .22 .14 .15 .16 .10$

11 Stagebeoordeling $\quad .14 .31 .46 .37 .28 .28 .18 .21 .24$

13 Algemeen oordeel $\quad .10 .30 .60 .51 .43 .41 .33 .20 .17 .30$

Correlaties tussen de gemiddelde domeinscores van $1989(\mathrm{~N}=875)$

Inspectie van de correlatiematrix laat zien dat de samenhang tussen een aantal domeinen redelijk hoog is. Dit zou een aanwijzing kunnen zijn dat aan een aantal domeinen hetzelfde construct ten grondslag ligt, wat een argument zou zijn om domeinen samen te voegen. Een andere verklaring zou kunnen zijn, dat bij het invullen sprake is geweest van het "Halo-effect". Hiermee doelt men op het verschijnsel dat beoordelaars soms impliciet relaties aangeven russen bepaalde aspecten, die van invloed kunnen zijn op het oordee van het object, bijvoorbeeld wanneer een student de begeleiding onvoldoende waardeert en alle overige aspecten van de stage eveneens onvoldoende beoordeeld worden (Larson, 1979). Indien er sprake is van het Halo-effect dan zullen de correlaties tussen de daaraan onderhevige domeinen hoog zijn. Uit tabel 8 valt af te leiden dat een aantal domeinen onderling laag correleert. Aangenomen wordt dan ook dat bij het invullen geen sprake is geweest van een Halo-effect over alle domeinen.

De volgende modellen zijn met behulp van de LISREL-methode getoetst.

Op theoretisch-pragmatische gronden is gesteld dat er 11 domeinen onderscheiden kunnen worden in de vragenlijst. Dit heeft ertoe geleid om een model met elf domeinen te toetsen. 
De begeleidingsdomeinen (D3, D4, D5) correleren onderling sterk $(r>.50)$. Dit ligt in de lijn van de verwachting. Op inhoudelijke gronden is een samenhang te verwachten tussen domeinen die allen betrekking hebben op begeleidingsaspecten. Hieruit volgi dat hel verdedigbaar is om alle begeleidingsitems tot een hetzelfde domein te rekenen. Dit zou pleiten voor een model waarbij uitgegaan wordt van negen domeinen.

$\mathrm{Er}$ is een redelijke correlatie $(r>43)$ tussen de begeleidingsdomeinen (D3, D4, D5) en het algemeen oordeel (D13). Ook dit is verdedigbaar. Het is niet onwaarschijnlijk dat de begeleiding zeer bepalend is voor het oordeel over een stage. Het algemeen oordeel zal dan ook hoog correleren met deze domeinen. Dit zou pleiten voor een model waarbij uitgegaan wordt van acht domeinen waarbii enerzijds de D3, D4, D5 en D1 3 tezamen als een hetzelfde domein beschouwd worden en anderzijds de overige domeinen als afzonderliike beschouwd worden

Tussen de domeinen D3, D4, D5, D8 en D1 3 is een redelijke correlatie $(r>.30$ en $r<.70)$. Deze domeinen hebben betrekking op de begeleiding, de patiëntgebonden leersituaties en het algemeen oordeel. Dit zou pleiten voor een model bestaande uit zeven domeinen waarbij D3, D4, D5, D8, D1 3 rezamen als een domein beschouwd worden en de overige domeinen als afzonderliike.

Domein 1 (voorbereiding), domein 9 (polikliniek) en domein 10 (faciliteiten), correleren zeer laag met alle overige domeinen. Hieruit volgt dat domein 1, 9 en 10 in ieder geval afzonderliike domeinen zijn. Domein 13 (algemeen oordeel) correleert redelijk tot sterk met domein 2 (stageboek), domein 3 (persoonsgebonden begeleiding), domein 4 (begeleiding medisch-technisch), domein 5 (aandacht voor patiënt en conlext\}, domein 7 (aanbod patiëntproblemen), domein 8 (patiëntgebonden leersituaties) domein 11 (stagebeoordeling). Domein 1, 9 en 10 correleren nauwelijks met domein 13. Op basis hiervan is het verdedigbaar vit te gaan van een model met vier domeinen: DI (voorbereiding), D9 (polikliniek), D 10 (faciliteiten) en de overige domeinen als een gezamenlijke domein.

Domein 13 (algemeen oordeel) correleert sterk met de begeleidingsdomeinen (>.43). Dit pleit voor een model met twee domeinen, waarbij enerzijds D3, D4, D5, D1 3 als één en hetzelfde domein beschouwd worden en anderzijds D1, D2 D7, D8, D9, D 10, D 11 tezamen als een tweede domein. 
Tenslotte is het nul-model getoetst waarbij aangenomen wordt dat alle domeinen ongecorreleerd zijn en er geen samenhang is.

In tabel 9 staan de diverse modellen weergegeven.

Aantal domeinen

Elf domeinen

Negen domeinen

Acht domeinen

Zeven domeinen

Vier domeinen

Twee domeinen

Nul-model nummers domeinen

D1-D2-D3-D4-D5-D7- D8-

D9. D10-D11-D13

$D 3+D 4+D 5$

D1-D2-D7-D8-D9-D10-D11-D13

$D 3+D 4+D 5+D 13$

D1-D2-D7-D8-D9-D10. D11

$D 3+D 4+D 5+D 8+D 13$

D1-D2-D7-D9-D10-D11

$D 2+D 3+D 4+D 5+D 7+D 8+D 11+D 13$

D1- D9. D10

$D 3+D 4+D 5+D 13$

$D 1+D 2+D 7+D 8+D 9+D 10+D 11$

ongecorreleerd

De beschreven modellen zijn getoetst met behulp vain de LISREL-methode 


\subsubsection{Resultaten}

De USREL-methode is toegepast om na te gaan of het beoogde modiel en de alternatieve modellen passen bil de geobserveerde data. in tabel 10 sitoan de relevante gegevens voor de verschillende foetsingen vermeld.

Uit tabel 10 blijkt dat de CHI-kwadraat in alle gevallen significant is. Op basis van deze maal zou geconcludeerd moeten worden dat alle gepostuleerde modellen atwiliken van de geobserveerde data. De GFl en de AGF ziin matig. De RMSR is voor het model met 11 onderscheiden domeinen acceptabel en ligt onder het criterium van .07 dat normaliter gehanteerd wordt. Rho ligt voor de modellen met $7,8,9$ en 11 onderscheiden domeinen boven de 80 , wat zeer redelik is. Over het geheel genomen zịn de fikindices het gunstigs? woor het model met 11 domeinen. Ahoewel ook hiervoor de ratio $X^{2} / \mathrm{df}$ aan de hoge kant (4.5) is, zipn de GFl, de AGFl en de RMSR redelijk. De alternatieve index rho is bij het model met $\|$ domeinen .89 , wat zeer acceptabel is. In het voorgaande is reeds gewezen op de invloed van de groofte van de steekproef op de $\chi^{2}$ waarde. Kleine steekproeven leiden sneller tot een niet-significante $\chi^{2}$. Het model met 11 domeinen is daarom nogmads vitgevoerd op een beperkle a-selecte steekproef $(\mathrm{N}=200)$ van het databestand.

Deze resultaten laten een aanmerkelijke daling van $\chi^{2} /$ dif-ratio zien. De $\chi^{2} / \mathrm{df}$ ratio bedraagt 1 , hetgeen niet significant is. Bij een kleine steekproef blijkt er dus geen significante afwijking meer te zijn tussen model en de geobserveerde data. De GFI en de AGFI zijn stabiel, deze zijn onafhankelijk van de steekproefgrootte $\left(x^{2}=1006.40, p=.27, d f=979\right)$.

Tabel 10 Resultaten modeltoetsingen

\begin{tabular}{|lrlllllll|}
\hline $\begin{array}{l}\text { oantal } \\
\text { domeinen }\end{array}$ & $d f$ & $\chi^{2}$ & $p$ & GFI & AGF & RMSR & rho \\
\hline 0 & 132 & 4173.37 & .00 & .578 & $*$ & .247 & $*$ \\
\hline 2 & 1033 & 9142.98 & .00 & .595 & .558 & .087 & .74 \\
4 & 1028 & 9032.60 & .00 & .587 & .547 & .085 & .74 \\
7 & 1013 & 7009.52 & .00 & .625 & .582 & .076 & .81 \\
8 & 1006 & 6676.06 & .00 & .634 & .589 & .075 & .82 \\
9 & 998 & 6556.95 & .00 & .640 & .590 & .075 & .82 \\
11 & 979 & 4420.06 & .00 & .721 & .678 & .059 & .89 \\
\hline & & & & & & & \\
\hline
\end{tabular}


Op basis hiervan kan geconcludeerd worden dat het model met 11 domeinen op empirische gronden het best past. Alhoewel de overeenstemming tussen dit model en de data niet optimaal is, blijkt het zeker in vergelijking met alternatieve modellen zeer acceptabel. Er zijn dan ook geen zwaarwegende argumenten om het model met 11 domeinen te verwerpen. Besloten wordt om gezien de duidelijke rationale die aan het instrument ten grondslag ligt en de pragmatische bruikbaarheid het model in de voorgestelde vorm te handhaven. Om aan te geven dat de domeinen op statistische gronden niet zondermeer identificeerbaar zijn, blijven we de term domeinen hanteren en niet de term factoren.

\subsection{Studie 5: Invariantie van correlatiematrices}

\subsubsection{Inleiding}

Op basis van de analyses die zijn weergegeven in de vorige paragraaf kan geconcludeerd worden dat het gepostuleerde model van 11 domeinen matig tot redelijk past bij de empirische data. Een volgende stap is om na te gaan in hoeverre deze structuur consistent is over verschillende jaren. Wanneer correlaties tussen domeinen constant zijn over opeenvolgende jaren en dus onathankelijk zijn van het jaar waarin de metingen hebben plaatsgevonden, is dit een aanwiizing voor de constructvaliditeit. Deze studie toetst of de correlatiematrices invariant zijn. Hierbij wordt verondersteld dat er geen essentiële veranderingen in de opzet van de programma's van de stages hebben plaatsgevonden (Gijselaers, 1988; Marsh \& Hovecar, 1983).

\subsubsection{Methode}

Met behulp van het programma LISREL $V$ werden de correlatiematrices van $1989(N=875)$ en $1990(N=851)$ op hun invariantie onderzocht (Jöreskog \& Sörbom, 1978). De vraag is dus of alle elementen uit matrices van 1989 en 1990 gelijk zijn. Geobserveerde verschillen zijn dan random flucluaties. Op basis hiervan wordt antwoord verkregen op de vraag of het construct stabiel is over opeenvolgende jaren en niet afhankelijk is van toevalsfluctuaties. Er waren respectievelijk 875 en 851 waarnemingen beschikbaar (zie bijlage 2). Evenals in studie 4 is uitgegaan van 11 domeinen.

LISREL toetst in hoeverre de correlaties tussen geobserveerde variabelen kunnen worden gereproduceerd door een a-priori gespecificeerd causaal model. Om invariantie te onderzoeken wordt op basis van de correlatiematrices van 1989 en 1990 een nieuwe correlatiematrix gereproduceerd: correlatiematrix SIGMA (model H). 
Dit veronderstelt de specificatie van drie matrices: de LAMBDA-X matrix, de PHI matrix en de THETA-DELTA matrix. Vervolgens wordt de originele matrix met de volgens het model gereproduceerde matrix vergeleken. Een significante $\mathrm{CHI}$-kwadraat is een teken voor verschillen fussen de originele en gereproduceerde matrix.

\subsubsection{Resultaten}

Als nulmodel werd gekozen voor een siluatie waarbij alle domeinen ongecorreleerd zijin en de correlaties buiten de diagonaal dus nul zijn. Als uitgangspunt voor de modelfit werd eerst onderzocht of de buitendiagonaal-correlaties van de originele correlatiematrices substantieel waren (groter dan 0). Een significante $\chi^{2}$ is een teken voor verschillen tussen de originele en gereproduceerde matrix. Zoals reeds gezegd kan een goede fit bij grote populaties toch tor een significante CHI-kwadraat leiden. Andersom kan bij een kleine steekproef een slechte fit tor een non-significante $\chi^{2}$ leiden. Daarom is ook in deze studie de alternatieve index rho berekend die steekproefonafhankelijk is. Als de waarde van rho groter is dan .90 dan is er weinig tot geen verschil tussen de originele en gereproduceerde correlatiesmatrices. In tabel 11 zijn de resultaten weergegeven (Marsh \& Hocevar, 1983)

Tabel 11 Samenvatting van de getoetste modellen

\begin{tabular}{|lrrrr|}
\hline & $\chi^{2}$ & $d f$ & $p$ & rho \\
\hline Nulmodel & & & & \\
Model H (SIGMA) & 4173.37 & 132 & .00 & \\
Verschil & 124.56 & 66 & .00 & .97 \\
& 4048.81 & 66 & .00 & \\
\hline
\end{tabular}


Het nulmodel leverde een $\chi^{2}$ toets met het volgende resultaat: $\mathrm{CHI}$ kwadraat $=4173.73, d f=132, p=0.000$. Een toets van gelij|ke $\mathrm{PHI}-$ matrixen, dat wil zeggen waarin de correlaties tussen de onderscheiden domeinen voor beide jaren identiek zijn, leverde de volgende resultaten op: $\chi^{\prime}=124.56, d f=66, p=0.00$. Het model $\mathrm{H}$ heeft een $\mathrm{CHI}-\mathrm{kwadraat}$ van 1.88 per vrijheidsgraad, hetgeen nietsignificant is. De waarde van rho is 97 , eveneens een indicatie voor niet-significantie. Het verschil met het nulmodel is daarentegen wel significant; een $\mathrm{CHI}-\mathrm{kwadraat}$ van 61 per vrijheidsgraad. Hieruit volgt dat niet voldaan wordt aan het nul-model. Uit dit resultaat kan geconcludeerd worden dat de correlaties tussen de onderliggende domeinen van de vragenlijst stabiel zijn over een bepaalde tijdsperiode (in dit geval twee jaren). Kortom deze gegevens zijn een indicatie dat de geobserveerde correlatiematrices met betrekking tot de jaren 1989 en 1990 invariant zijn en onafhankelijk van het jaar waarin de metingen plaatsvonden. De uitkomsten van deze studie kunnen eveneens als een aanwijziging voor de constructvaliditeit van het meetinstrument gezien worden.

\subsection{Samenvatting}

In dit hoofdstuk zijn twee studies naar de validiteit van het instrument besproken. In studie 4 is met behulp van toetsende factoranalyse onderzocht in hoeverre de op inhoudelijk-pragmatisch gebaseerde indeling in domeinen ook op empirische gronden aanwijsbaar is. Op inhoudelijke gronden is het niet onwaarschijnliik dat de domeinen niet geheel onafhankelijk van elkaar zijn. Daarom zijn een aantal alternatieve modellen onderzocht, waarbij domeinen samengevoegd zijn. Op basis van de fit-indices kan geconcludeerd worden dat het gehanteerde model acceptabel is, zeker in vergelijking met de alternatieve modellen. Op basis hiervan is besloten de voorgestelde indeling in domeinen te handhaven. In studie 5 is onderzocht in hoeverre de indeling in domeinen over verschillende jaren stabiel is. Hiertoe is de invariantie tussen de correlatiematrices van 1989 en 1990 onderzocht. Op basis hiervan kan geconcludeerd worden dat de structuur redelijk stabiel is. Beide studies vormen een indicatie voor de constructvaliditeit van het instrument. 


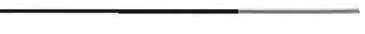




\section{Betrouwbaarheid van het instrument}

In het vorige hoofdstuk is validiteit van het instrument besproken. Geconcludeerd kon worden dat het instrument gezien de doelstelling voldoende valide is. In dit hoofdstuk wordt ingegaan op de betrouwbaarheid van de scores. De betrouwbaarheid wordt onderzocht met behulp van de generaliseerbaarheidstheorie. Paragraaf 9.1 geeft een algemene inleiding over het begrip betrouwbaarheid, bezien vanuit de klassieke testheorie. Paragraaf 9.2 gaat in op de achtergronden van de generaliseerbaarheidstheorie. Paragraaf 9.3 tot en met 9.6 geven een beschrijving van drie generaliseerbaarheidsstudies die zijn uitgevoerd naar de betrouwbaarheid. In paragraaf 9.7 word afgesloten mel een samenvatting.

\subsection{Inleiding betrouwbaarheid}

Betrouwbaarheid verwijst naar de precisie van gegevens verkregen met behulp van een meetinstrument (Drenth, 1985). Evenals bij de validiteit zijn er verschillende wegen om tot een schatting van de betrouwbaarheid te komen. Men moet zich bezinnen op de aard van het instrument en van de te meten eigenschap om op grond daarvan de meest geschikte betrouwbaarheidsbepaling te kiezen. De basis van betrouwbaarheidsberekeningen is gelegen in de klassieke testheorie. De klassieke testtheorie veronderstelt dat een geobserveerde score, verkregen met een meetinstrument, de resultant is van de ware score en allerlei fouten in het meetproces (de errorscore) (Lord \& Novick, 1968). Deze relatie kan als volgt weergegeven worden:

$$
O=W+E
$$

$\mathrm{O}=$ geobserveerde score

$W=$ ware gedeelte van de score

$E=$ het toevallige gedeelte van die score, de meetfout. 
De variantie van de geobserveerde score is gelijk is aan de som van varianties van de ware scores en de errorscores: Var $O=\operatorname{Var} W+$ Var $E$. De betrouwbaarheid van een meting is gelijk aan de ratio van de variantie van de ware scores en de variantie van de geobserveerde scores. Naarmale er meer sprake is van errorvariantie zal de coëfficiënt een lagere waarde aannemen.

Aan de berekening van de betrouwbaarheid in de klassieke testtheorie ligt het concept van parallelle metingen ten grondslag. Er worden twee hoofdwegen tot het schatten van de betrouwbaarheid onderscheiden. Ten eerste de weg van het herhaald testonderzoek en ten tweede bewerkingen van een enkel testonderzoek (Drenth, 1985). Bij herhaald testonderzoek wordt een uitspraak gedaan over de betrouwbaarheid door van eenzelfde respondentgroep de scores op een test te correleren met de scores op een andere soortgelijke test die veronderstelt hetzelfde te meten. Een hoge correlatie is een indicatie dat beide instrumenten hetzelfde meten. Men spreekt in dit geval van paralleltestbetrouwbaarheid, vitgedrukt in een a-specificiteitscoëfficiënt. Een andere methode die gestoeld is op hetzelfde principe als de paralleltestbetrouwbaarheid is de testhertestbetrouwbaarheid. Hierbij wordt eenzelfde test tweemaal bij dezelfde groep respondenten afgenomen. Wanneer men de test zelf een tweede maal afneemt wordt dit als een soort paralleltest van zichzelf gezien. Dit leidt tot de vraag hoe stabiel datgene is wat gemeten wordt. De betrouwbaarheid wordt bepaald door de correlaties tussen de testprestaties bij de eerste en tweede afname te berekenen. De testhertest-betrouwbaarheid wordt uitgedrukt in de stabiliteitscoëfficiënt. Bij bewerkingen van testen op basis van een enkel testonderzoek berekent men de betrouwbaarheid via een bewerking van de gegevens die binnen een toetsafname zijn verwerkt. De splithalf-betrouwbaarheid gaat vit van een random splitsing van de toets in twee helften, die dan als het ware als twee parallelvormen worden beschouwd. Bij deze procedure verkriigt men een schatting van de mate waarin twee testhelften onderling samenhangen en de test in vergelijking van de ene helft met de andere helft een consistent beeld vertoont. Deze methode levert een coëfficiënt voor interne consistentie op. Een tweede vitvoering gaat uit van het idee de test op te splitsen in meerdere gelijke delen. Uiteindelijk komt men dan terecht op het niveau van de afzonderlijke items en men berekent hoeverre van item tot item precies hetzelfde wordt gemeten. Deze methode is gebaseerd op itemanalyse en leidt tot de coëfficiënt van itemconsistentie of homogeniteit. Uitgaande van een methode is het binnen de klassieke testheorie niet mogelijk om de errorscore te specificeren in verschillende soorten foutenbronnen en uitspraken te doen over de mate waarin deze bijdrage tot de totstandkoming van 
de geobserveerde score.

In hoofdstuk 6 is reeds aan de orde gekomen dat de interpretatie van de scores van de vragenlijst per domein op twee niveaus plaatsvindt. Allereerst op het niveau van de stages (bijvoorbeeld interne geneeskunde), vervolgens op het niveau van de stageplaats (bijvoorbeeld interne geneeskunde binnen AZM). Afhankelijk van het niveau waarop uitspraken gedaan worden zullen andere bronnen bijdragen tot de ware variantie en de errorvariantie, bijvoorbeeld op het niveau van de stages zijn we geïnteresseerd in verschillen tussen stages en niet in verschillen tussen ziekenhuis. Op disciplineniveau zijn verschillen tussen ziekenhuizen juist wel relevant. Voor elk niveau dienen dan ook verschillende betrouwbaarheidsschattingen verricht re worden. Dit vraagt om een theorie waarmee het mogelijk is een uitsplitsing te maken van een diversiteit aan relevante variantiebronnen en zelf te bepalen wat als errorvariantie opgevat wordt. Met de klassieke testtheorie is het niet mogelijk een dergelijke vitsplitsing in variantiebronnen te maken. Een theorie die dit wel mogelijk maakt is de generaliseerbaarheidstheorie.

De generaliseerbaarheidstheorie is een uitbreiding van de klassieke testtheorie (Cronbach et al., 1972). Het concept van betrouwbaarheid, zoals opgevat in de klassieke testheorie, is vervangen door een ruimere en meer flexibelere opvatting van betrouwbaarheid, namelijk generaliseerbaarheid. In plaats van de vraag hoe accuraat geobserveerde scores de ware scores reflecteren, wordt bij de generaliseerbaarheidstheorie ingegaan op de vraag hoe accuraat geobserveerde scores toestaan te generaliseren over het object van de meting. In de generaliseerbaarheidstheorie is het gebruikelijk om van reproduceerbaarheidscoëfficiënten te spreken in plaats van betrouwbaarheidscoëfficiënten (Shavelson et al., 1989, 1991; van der Vleuten \& Wijnen, 19911.

\subsection{Generaliseerbaarheidstheorie}

Bij de generaliseerbarheidstheorie is evenals in de klassieke lestheorie sprake van een ware score ("universe score") en een geobserveerde score. De reproduceerbaarheidscoëfficiënt wordt bepaald door de verhouding ware variantie en de geobserveerde variantie. Deze coëfficiënt toont hoe accuraat de generalisatie is van een geobserveerde score naar een universum en is vergelijkbaar met de indices (bijvoorbeeld alpha) uit de klassieke testheorie. De ware variantie wordt bepaald door het object van meting - datgene waarin men variantie wenst te vinden - bijvoorbeeld de variantie tussen stages of tussen stageplaatsen. De geobserveerde variantie is afhan- 
kelijk van de uitspraken die de onderzoeker wenst te doen. Afhankelijk van het universum waarnaar de onderzoeker de resultaten wil generaliseren, worden alle variantiebronnen die voor dat doel verstorend zijn, in de geobserveerde variantie meegenomen. Daarbij gaat het er bijvoorbeeld om vast te stellen of met dezelfde items een vergelijkbare score wordt verkregen bij dezelfde populatie studenten dan wel of een vergelijkbare score verkregen wordt met dezelfde items bij een andere populatie. Met andere woorden belangrijk is vast te stellen over welke én hoeveel condities (studenten en/of irems) de onderzoeker wil generaliseren. Een omschrijving van het gebruiksdoel van het instrument is daarom noodzakelijk. Voor elk gebruiksdoel wordt een reproduceerbaarheidsindex berekend.

\section{Vraagstellingen}

Het instrument voor stage-evaluatie is bedoeld om uitspraken te doen over de kwaliteit van co-assistentschappen. Hel doel van de generaliseerbaarheidsstudies in deze context is tweeledig:

ten eerste om een indicatie te krijgen van de betrouwbaarbaarheid (accuraatheid) van de scores en van beslissingen die genomen worden met behulp van het instrument; ten tweede om vast te stellen hoeveel waarnemingen van studenten nodig zijn om een betrouwbaar oordeel te kunnen geven.

De laatst genoemde informatie kan leiden tol een efficiënte(re) opzet van de dataverzameling, bijvoorbeeld door het aantal studenten te beperken dat de vragenlijst aan het einde van een stage moet invullen. Het is viteraard ook mogelijk om studies uit te voeren, waarbij het aantal items per domein varieert. Op basis hiervan zou vastgesteld kunnen worden met hoeveel items elk domein uitgebreid of ingekort zou kunnen worden voor een acceptabele betrouwbaarheid. In deze studie is van deze optie afgezien, omdat we vitgaan van de tot op heden gebruikte vragenlijst.

In hoofdstuk 6 is gesteld dat met behulp van het instrument uitspraken op twee niveaus gedaan worden, namelijk op het niveau van de stages èn de stageplaatsen. Hieruit volgt dat er twee gebruiksdoelen zijn (figuur 12). 


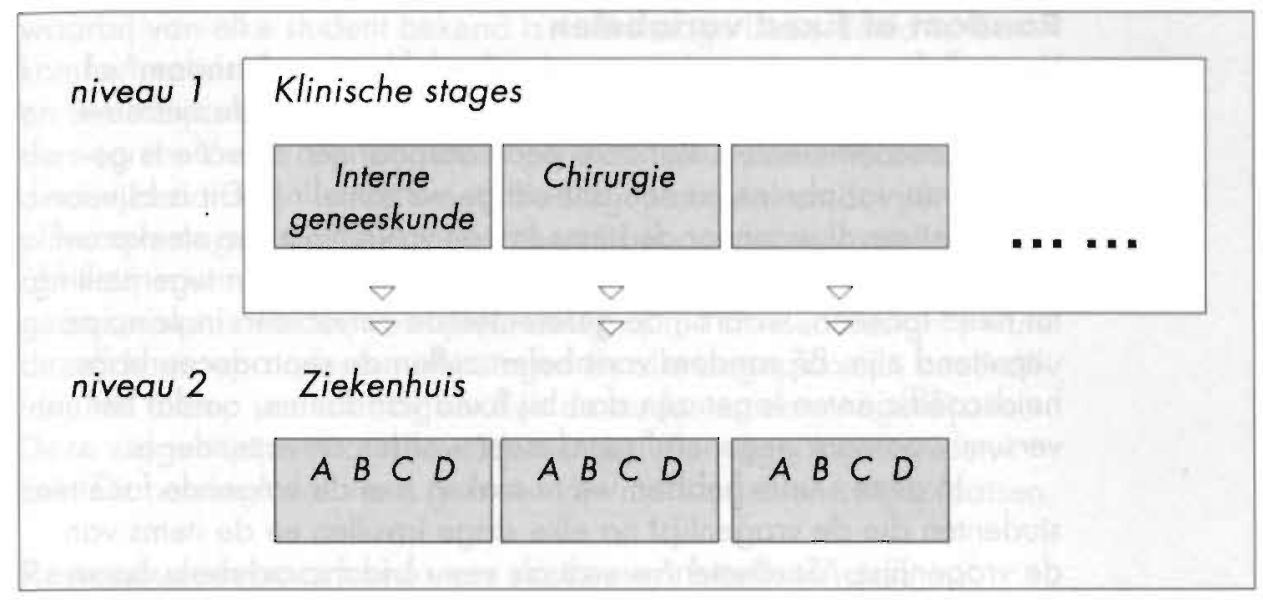

Schema van de gebruiksdoelen

Figuur 12

De betrouwbaarheidsvragen moeten op het niveau van de stage èn de stageplaats beantwoord worden. Elk gebruiksdoel heeft een ander object van meting, waardoor de ware variantie verschilt. Op niveau 1 zijn we geïnteresseerd in de variantie tussen stages. Op niveau 2 in de variantie tussen stageplaatsen binnen een en dezelfde discipline. Bii de schattingen van de betrouwbaarheid worden steeds andere foutenbronnen meegenomen. Wat tot foutenbronnen wordt gerekend, is afhankelijk van de vitspraken die men op basis van de gegevens wil doen. Foutenbronnen worden in de generaliseerbaarheidstheorie aangedvid als "facetten".

\section{G-studies en D-studies}

Een betrouwbaarheidsstudie die gebruik maakt van de generaliseerbaarheidstheorie bestaat in feite vit twee stappen: de generaliseerbaarheidsstudie (G-studie) en besluitvormingsstudie (decision-study; D-studie). In de G-studie worden alle variantiebronnen van zowel de foutenbronnen als de gewenste variantiebronnen in kaart gebracht. Variantiecomponenten op basis van ANOVA mean-squares worden geschat volgens standaardprocedures (Cronbach et al., 1972). In de D-studie worden de variantiecomponenten van de G-studie vervolgens gebruikt om concrete betrouwbaarheidsberekeningen uit te voeren. Wanneer uit de G-studie bekend is hoe groot de verschillende variantiecomponenten zijn, kan worden nagegaan met welke aantallen (studenten, items) gewerkt dient te worden voor het behalen van een aanvaardbare betrouwbaarheid (Brennan, 1983; Crocker, Llabre \& Miller, 1988; Cronbach el al. 1972; Shavelson, Webb \& Rowley, 1989; van der Vleuten \& Wijnen, 19911. 


\section{Random of fixed variabelen}

Voor elk facet moet aangegeven worden of het een "random" of "fixed" variabele betreft, omdat dit van invloed is op de betrouwbaarheidscoëfficiënten. Random geeft aan dat een selectie is gemaakt van variabelen uit een oneindige verzameling. Dit is bijvoorbeeld hel geval wanneer de items in een vragenlijst een steekproef zijn uit een grote verzameling van mogelijke items. Dit in regenstelling tot fixed facetten, waarbii de geselecteerde variabelen in principe uitputtend zijn. Bij random variabelen zullen de reproduceerbaarheidscoëfficiënten lager zijn dan bij fixed variabelen, omdat het universum waarnaar gegeneraliseerd moet worden omvattender is.

In deze studie hebben we te maken met de volgende facetten: studenten die de vragenlijst na elke stage invullen en de items van de vragenlijst. "Studenten" wordt als een random variabele opgevat, omdat de studentenpopulatie elk jaar varieert en de stages steeds door andere studenten vit de populatie doorlopen worden. "Items" worden eveneens als een random variabele opgevat, omdat voor elk domein in principe meerdere items denkbaar zijn en de verzameling in zoverre niet uitputtend is (zie hoofdstuk 5). Het zou overigens verdedigbaar zijn om items als een fixed variabele op te vatten, omdat getracht is een zo volledig mogelijke dekking van het domein te geven en de studenten elk jaar exact dezelfde vragenlijst voorgelegd krijgen. Gekozen is hier voor de meest "ongunstige" (kwetsbaarste) opstelling, zodat de betrouwbaarheidsgegevens in de hiernavolgende studies eerder een onderschatting dan een overschatting van de werkelijkheid zullen zijn.

\section{Gekruiste of geneste designs}

Per facet moet aangegeven worden of sprake is van kruising of nesling mel andere facetten. Bij kruising kunnen geïsoleerde uitspraken gedaan worden over alle mogelijke foutenbronnen. Een voorbeeld van een gekruist design is wanneer dezelfde groep studenten alle stages en alle stageplaatsen op dezelfde items beoordeelt. Voor alle facetten kunnen dan afzonderlijk de foutenbronnen geschat worden. Bij nesting daarentegen zijn een aantal bronnen niet meer te isoleren omdat een verstrengeling heeft plaatsgevonden, bijvoorbeeld als studenten slechts over een beperkt aantal stageplaatsen uitspraken doen. Hieruit volgt dat bij gekruiste designs de meest genuanceerde informatie verkegen wordt. In de praktijk is het echter niet altijd haalbaar om alle factoren te kruisen en zal veelal sprake zijn van geneste designs.

In deze studie zijn studenten genest binnen co-assistentschappen. Alhoewel studenten in principe alle stages doorlopen in een periode van twee jaar, is er niet de beschikking over een dataset 
waarbij van elke student bekend is welke stage beoordeeld is. Dit komt enerzijds doordat studenten de vragenlijsten anoniem invullen en anderzijds doordat de gebruikte dataset gebaseerd is op meerdere jaren. Voorts zijn studenten genest binnen ziekenhuizen. Studenten beoordelen immers niet alle stageplaatsen, omdat per discipline een stage wordt gelopen in hetzij het academisch ziekenhuis of hetzij in een van de affiliatieziekenhuizen. Dit betekent dat er géén sprake is van een compleet design ("full crossed design") waar dezelfde groep studenten alle stages én alle stageplaatsen beoordelen. Na afloop van elk stage vullen de studenten een vragenlijst in. Deze vragenlijst is voor alle studenten én alle stageplaatsen identiek. Dit betekent dat items gekruist zijn met stages en stageplaatsen.

\section{Reproduceerbaarheid van scores en beslissingen}

De interpretatie van de scores, die met behulp van het instrument verkregen worden, kan op diverse wijzen plaatsvinden, namelijk vanuit een een relatiefgeoriënteerd perspectief en vanuit een absoluutgeoriënteerd perspectief. Afhankelijk van het soort benadering zullen andere foutenbronnen als error opgevat worden en dus van invloed zijn op de betrouwbaarheidscoëfficiënten. Betrouwbaarheid vanuit een relatiefgeoriënteerd perspectief geeft de scores van stages betekenis in relatie tot elkaar, bijvoorbeeld welke stage of welke stageplaats behoort tot de beste en welke tot de slechtste. Bii de berekening van de betrouwbaarheid worden uitsluitend foutenbronnen opgenomen die de rangorde van stages respectievelijk stageplaatsen wat betreft hun kwaliteit benvloeden. De betrouwbaarheidscoëfficiënt volgens een relatiefgeoriënteerd perspectief wordt vitgedrukt in een generaliseerbaarheidscoëfficiënt. Betrouwbaarheid vanuit een absoluutgeoriënteerd perspectief geeft een absolute betekenis aan scores (zie hoofdstuk 6). Scores van stageplaatsen worden hierbij niet vergeleken met de scores van andere stageplaatsen. $\mathrm{Bij}$ de berekening van de betrouwbarheid vanuit een absolute interpretatie worden zowel verschillen tussen studenten als verschillen tussen items als mogelijke foutenbronnen opgevat. De betrouwbarheidscoëfficiënt volgens een absoluutgeoriënteerd perspectief wordt vitgedrukt in een phi-coëfficiënt. Een alternatieve benadering vanuif een absoluutgeoriënteerd perspectief is om niet uit te gaan van de reproduceerbaarheid van de scores, maar van de reproduceerbaarheid van beslissingen. Dit betekent dat aangegeven wordt welke stageplaats onder een bepaalde grenswaarde liggen. De onderzoeker geeft zelf aan wat de grenswaarde is. De betrouwbaarheidscoëfficiënt volgens een beslissingsgeoriënteerd perspectief wordt vitgedrukt in een adjusted-phi-coëfficiënt. Figuur 13 bevat een overzicht van de mogelijke reproduceerbaarheidscoëfficiënten. 


\begin{tabular}{|lll|}
\hline Benadering & Kenmerk & $\begin{array}{l}\text { Reproduceerbaar- } \\
\text { heidscoëfficiënt }\end{array}$ \\
\hline Relatiefgeoriënteerd & $\begin{array}{l}\text { onderlinge vergelijking } \\
\text { tussen stages/stageplaatsen }\end{array}$ & G-coëfficiënt \\
\hline Absoluutgeoriënteerd - absolute verschillen & Phi-coëfficiënt \\
tussen scores & - afwijking t.o.v. grensscore & Adjusted phi-coëfficiënt \\
\hline
\end{tabular}

Figuur 13 Overzicht van de mogelijke benaderingen en bijbehorende reproduceerbaarheidscoëfficiënten

In deze studie zijn we allereerst geïnteresseerd in onderlinge vergelijkingen, dus op gebruiksdoel niveau 1 welke stages relatief goed, gemiddeld of slechr zijn, op niveau 2 welke stageplaatsen binnen een discipline relatief goed, gemiddeld of slecht zijn. Voor deze relatieve benadering is gekozen omdat onbekend is wat de schaalwaarden in absolute zin betekenen. Om een bepaald minimumniveau te garanderen wordt daarnaast gebruik gemaakt van een absolute benadering, waarbii een grensscore gedefinieerd is. Hierdoor kan een scheiding aangebracht worden tussen stages en stageplaatsen met een onvoldoende score en een voldoende score (zie paragraaf 6.2.11. Hierbij is het niet van belang hoeveel een gemiddelde score van een stage of stageplaats onder een waarde ligt, maar of een score onder de kritieke grens ligt. Indien een gemiddelde score van een stage of stageplaats onder de absolute grenswaarde ligt, vraagt dit altijd om maatregelen. Dit vereist de definiëring van een absolute grenswaarde. Hierbij is de volgende redenering gevolgd. De beoordeling door studenten vindt plaats aan de hand van een viifpuntsschaal (1-5). Als absolute ondergrens is gesteld dat een gemiddelde score voor een domein van lager dan 3 onvoldoende is en in ieder geval aanleiding moet zijn om verandering in een stage aan te brengen. Een vitzondering hierop vorm domein 13 (algemeen oordeel over de stage). De hierbii behorende score wordt vitgedrukt in een tienpuntsschaal. Als absolute ondergrens voor dit domein geldı score 6 . Naarmale de cesuur verder verwijderd ligt van de gemiddelde behaalde score verandert de betrouwbaarheid van de beslissing aanzienlijk (van der Vleuten \& van Luyk, 1988). 
Samenvattend: In deze studie worden de reproduceerbaarheidscoëfficiënten berekend vanuit een relatief georiënteerd perspectief (Gcoëfficiënt) en vanuit een beslissingsgeoriënteerd perspectief (adjusted phi-coëfficiënt). De berekening hiervan vindt plaats aan de hand van de volgende formules:

$$
\begin{aligned}
& \text { Generaliseerbaarheidscoëfficiënt }=\quad \frac{\hat{\sigma}^{2}(T)}{\hat{\sigma}^{2}(T)+\hat{\sigma}^{2}(\delta)} \\
& \text { Adjusted } \text { p-coëfficiënt }=\quad \frac{\hat{\sigma}^{2}(T)+(\mu-\lambda)^{2}}{\hat{\sigma}^{2}(T)+(\mu-\lambda)^{2}+\hat{\sigma}^{2}(\Delta)} \\
& \begin{array}{ll}
\hat{\sigma}^{2}(T) & =\text { ware variatie } \\
\hat{\sigma}^{2}(\delta) & =\text { relatieve errorvariatie } \\
\hat{\sigma}^{2}(\Delta) & =\text { absolute errorvariatie } \\
\mu \quad & =\text { gemiddelde score } \\
\lambda \quad & =\text { grenswaarde }
\end{array}
\end{aligned}
$$

\section{Standaardmeetfout}

Bij het doen van uitspraken over stages gaat het natuurlijk om de bepaling van de ware score. Dat is datgene waarin we zijn geïnteresseerd. Wat we krijgen is slechts de geobserveerde score voor een stage of stageplaats. Hoe groter de spreiding van de verkregen scores rond de ware score, hoe groter de meeffout en hoe onbetrouwbaarder de meting met dit instrument. Met andere woorden een goede indicatie voor de betrouwbaarheid is de standaarddeviatie van de meetfout. Deze standaarddeviatie wordt de standaardmeeffout (standard error of measurement: SEM) genoemd. Indien de standaardmeetfout voor de onderzochte stages bekend zou zijn, zouden we in elk geval een idee hebben of de ware score ver van score $X$ verwijderd ligt of niet. Het zal duidelijk zijn dat enerzijds de standaardmeetfout voor welk doel dan ook zo laag mogelijk dient te zijn, anderzijds de conclusies aan waarde verliezen naarmate deze groter wordr (Drenth, 1985; Mehrens \& Lehmann, 1984). De SEM geeft dus de marge aan waarbinnen de ware score gevonden kan worden, gegeven de geobserveerde score. Stel dat de gemiddeld geobserveerde score voor een verzameling items score 3 bedraagt en de standaardmeeffout .5, dan kan gezegd worden dat er $95 \%$ kans bestaat dat de ware score voor dat cluster van items valt tussen $3+/-1.96 \times .5$ of ruwweg tussen 2 en 4 valt. De standaardmeetfout geeft dus de grenzen van het bereik aan, waarbinnen een 
score zich bevindt. Hier wordt vitgegaan van een waarschijnlijkheid van $95 \%$. In deze studie wordt een verschil van een schaalpunt tussen de ware score en geobserveerde score toelaatbaar geacht. Dit betekent dat de ware score maximaal lussen een halve score boven of onder de geobserveerde score ligt. Om mel een redelijke precisie uitspraken te kunnen doen zal bij een waarschijnlijkheid van $95 \%$ $(.5 / 1.96)$ de SEM voor de domeinen met een vijfpuntsschaal kleiner dan 26 moeten zijn. Bij domein 13 (algemeen oordeel) is gebruik gemaakt van een tientpuntsschaal. Dit betekent dat de SEM voor dit domein kleiner dan .50 moet zijn (Heller, 1978). De SEM is gelijk aan de wortel uit de relatieve errorvariantie. In formule:

Standaardmeetfout $=\quad \hat{\sigma}^{2}(\delta)$

$\hat{\sigma}^{2}(\delta)=$ relatieve errorvariatie

Aan de cruciale betekenis van de standaarmeetfout wordt in deze studie dan ook de grootste betekenis gehecht. Immers dan is duidelijk of de meting met dit instrument voldoende precies is, gegeven een acceptabele waarschijnlijkheid en dus een basis biedt om beslissingen re nemen.

\section{Methode}

De feitelijke generaliseerbaarheidsstudies zijn vitgevoerd met behulp van het programma GENOVA (Crick \& Brennan, 1983). Voor de vitvoering van de berekeningen is gebruik gemaakt van de data die van $1987 \mathrm{t} / \mathrm{m} 1990$ verzameld zijn. Het aantal waarnemingen dat per stage voor de onderscheiden domeinen vit de vragenlijst beschikbaar is, verschilt per stage ten gevolge van nonrespons, het ontbreken van bepaalde items in bepaalde jaren en het niel beschikbaar zijn van een identiek aantal waarnemingen voor elk stageplaats. Immers in affiliatieziekenhuizen wordt door minder studenten stage gelopen dan in het AZM. Voor de uitvoering van de analyses met GENOVA is een gebalanceerd aantal waarnemingen van studenten nodig. Dit betekent dat voor elke studie gestratificeerd naar hel object van meting studentwaarnemingen zijn getrokken uit hel totale databestand. Bij elke studie is aangegeven hoeveel studenten viteindelijk in de analyses betrokken zijn. Er volgł een bespreking van drie generaliseerbaarheidsstudies. 


\subsection{Studie 6: Generaliseerbaarheid over stages}

In deze eerste generaliseerbaarheidsstudie worden de reproduceerbaarheidscoëfficiënten en standaardmeetfouten geschat, ervan vitgaande dat uitspraken gedaan worden op het niveau van de stages in zijn algemeenheid. Hieruit volgt dat het object van meling de coassistentschappen zijn. Er is sprake van twee factoren, studenten en items. Het object van meting: de co-assistentschappen, wordt niet als aparte factor meegerekend. Variantiebronnen kunnen berekend worden voor de hoofdeffecten: co-assistentschappen (c), studenten genest binnen co-assistentschappen (s:c) en items (i) en twee interacties (i(s:c) en ci). Volgens de theorie is hier sprake van een twee factoren design: $\mathrm{c} \times(\mathrm{s}: \mathrm{c}\rangle) \mathrm{i}$.

\subsubsection{Analyseprocedure}

De analyses zijn uitgevoerd per domein. $E r$ is vastgesteld hoeveel waarnemingen per stage bruikbaar zijn. Vervolgens is nagegaan voor welke stage het minst aantal waarnemingen beschikbaar was. Uitgaande van dit aantal is voor alle stages een identieke random steekproef van studenten uit het totale bestand getrokken. Hierdoor ontstond een gebalanceerd design, met een gelijk aantal studentwaarnemingen per stage. Bijlage 3 bevat een overzicht van het aantal studenten dat gebruikt is voor de steekproeftrekking ten behoeve van de analyses. De variantiecomponenten zijn per domein allereerst voor de afzonderlijke stages berekend en vervolgens gemiddeld om een schatting van de totale effecten over alle stages te verkrijgen. De ware variantie, de relatieve en absolute variantie bevatten de volgende componenten:

$$
\begin{aligned}
& \hat{\sigma}^{2}(T)=\hat{\sigma}^{2} c \\
& \hat{\sigma}^{2}(\delta)=\hat{\sigma}^{2} s: c / n_{s}+\hat{\sigma}^{2} i(s: c) / n_{i} n_{s}+\hat{\sigma}^{2} c i / n_{i} \\
& \hat{\sigma}^{2}(\Delta)=\hat{\sigma}^{2} s: c / n_{s}+\hat{\sigma}^{2} i / n_{i}+\hat{\sigma}^{2} i(s: c) / n_{i} n_{s}+\hat{\sigma}^{2} c i / n_{i}
\end{aligned}
$$

\subsubsection{Resultaten}

\section{Variantiecomponenten}

Tabel 12 bevat de geschatte variantiecomponenten uitgesplitst per domein. 


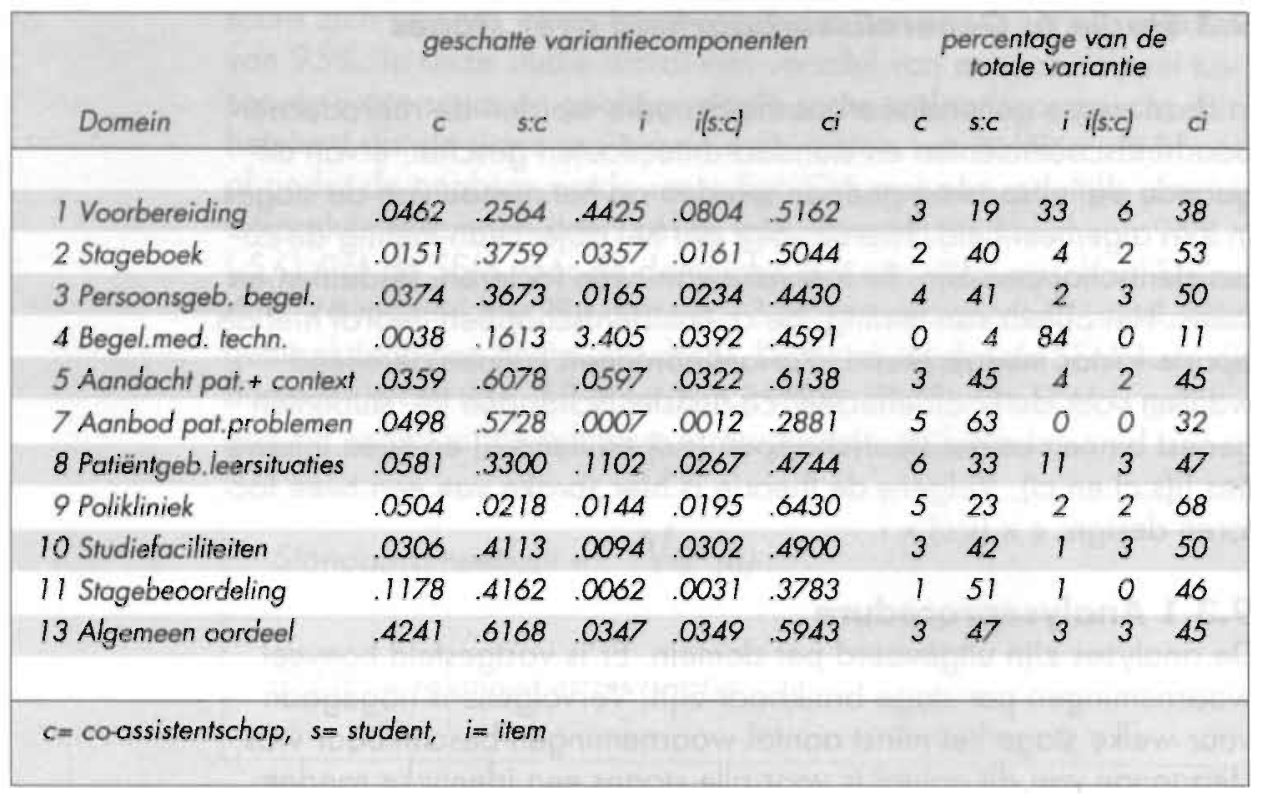

Tabel 12 Overzicht van de geschatte variantiecomponenten (studie 6)

Zoals meestal gebruikelijk is, bestaat voor het merendeel van de domeinen de grootste variantiebron uil error. Tussen stages blijken relatief weinig verschillen te zijn. Ook de variantiecomponenten voor ifems zijn relatief klein, blijkbaar zijn er tussen de items weinig gemiddelde verschillen met uitzondering van domein l (voorbereiding stage) en domein 4 (begeleiding medisch-technisch). De interpretatie van domein 1 moet gedifferentieerd zijn naar items, enerzijds op de voorbereiding op het gebied van kennis en anderzijds op het gebied van vaardigheden. Hetzelfde geldt voor domein 4 . $\mathrm{Bij}$ het geven van feedback aan docenten over deze domeinen is het belangrijk om aandacht te besteden aan de afzonderlijke items. Vergeleken met de overige variantiecomponenten is de variantiecomponent $(\mathrm{s}: \mathrm{c}$ ) voor studenten binnen co-assistentschappen aanzienlijk. Blijkbaar verschillen de beoordelingen van studenten onderling en over co-assistenschappen heen in ruime mate van elkaar. Om deze variantiecomponent exact te kunnen interpreteren, dient in overweging genomen le worden dat sludenten genest zijn binnen co-assistentschappen met als gevolg dat de afzonderlijke effecten van studenten (s) en het interactie-effect studenten $\times$ co-assistentschappen (sc) niet afzonderlijk geschat kunnen worden. Doordat er sprake is van een genest design en daardoor de interactiecompo- 
nent van "studenten met co-assistentschappen" (sc) verweven is in de component "studenten binnen co-assistentschappen" $(\mathrm{s}: \mathrm{c})$ is deze term relatief groot. Het is niet mogelijk de inconsistentie in de beoordeling over verschillende stages te schatten. Indien de beschikking was over een full-crossed design zou het wel mogelijk zijn geweest deze effecten te isoleren. Hierbij dient aangetekend te worden dat nesting voor de praktijk gunstig is, omdat dan niet steeds de gegevens ter beschikking behoeven te zijn over eenzelfde groep studenten die steeds dezelfde co-assistentschappen beoordeelt.

\section{Reproduceerbaarheid van scores}

De schattingen van de variantiecomponenten uit tabel 12 vormden de basis voor de schatting van de reproduceerbaarheidscoëfficiënten en de standaardmeetfouten, geprojecteerd naar verschillende studentaantallen. In tabel 13 staat het resultaat vermeld.

Overzicht van de G-coëfficiënt, SEM en adjusted phi-coëfficiënt (studie 6)

\begin{tabular}{|c|c|c|c|c|c|c|}
\hline $\begin{array}{l}\text { aantal } \\
\text { studenten }\end{array}$ & $\begin{array}{l}l \\
\text { voorbe- } \\
\text { reiding } \\
\text { G SEM adj }\end{array}$ & $\begin{array}{l}2 \\
\text { stogeboek } \\
\text { G SEM adj }\end{array}$ & $\begin{array}{l}3 \\
\text { pers.geb. } \\
\text { begeleiding } \\
\text { G SEM adj }\end{array}$ & $\begin{array}{l}4 \\
\text { begeleiding } \\
\text { med.fechn. } \\
\text { G SEM adj }\end{array}$ & $\begin{array}{l}5 \\
\text { aandacht } \\
\text { pat.+cont. } \\
\text { G SEM adj }\end{array}$ & $\begin{array}{l}7 \\
\text { aanbod } \\
\text { pat.probl. } \\
\text { G SEM adi }\end{array}$ \\
\hline 25 & .43 .25 .11 & .40 .15 .94 & .65 .14 .98 & .38 .19 .87 & .55 .17 .49 & .63 .17 .97 \\
\hline 50 & .48 .22 .12 & .54 .11 .96 & .76 .11 .99 & .48 .16 .90 & .69 .13 .62 & .77 .12 .98 \\
\hline 75 & .50 .22 .12 & .61 .10 .96 & .81 .10 .99 & .51 .15 .91 & .76 .17 .68 & .83 .10 .99 \\
\hline 100 & .51 .21 .12 & .65 .09 .97 & .83 .09 .99 & .54 .14 .92 & .79 .10 .71 & .87 .09 .99 \\
\hline 125 & .51 .21 .12 & .68 .08 .97 & .91 .06 .99 & .55 .14 .92 & .81 .09 .73 & .88 .08 .99 \\
\hline
\end{tabular}

\begin{tabular}{|c|c|c|c|c|c|}
\hline $\begin{array}{l}\text { oantal } \\
\text { studenter }\end{array}$ & $\begin{array}{l}8 \\
\text { pat. geb. } \\
\text { leersituaties } \\
\text { G SEM adj }\end{array}$ & $\begin{array}{l}9 \\
\text { polikliniek }\end{array}$ & $\begin{array}{l}10 \\
\text { studie } \\
\text { faciliteiten } \\
\text { G SEM adj }\end{array}$ & $\begin{array}{l}11 \\
\text { stage } \\
\text { beoordeling. } \\
\text { G SEM adi }\end{array}$ & $\begin{array}{l}13 \\
\text { algemeen } \\
\text { oordeel. } \\
\text { GSEM od }\end{array}$ \\
\hline 25 & .61 .19 .89 & .62 .18 .89 & .48 .18 .97 & .34 .15 .98 & .49 .21 .98 \\
\hline 50 & .70 .15 .90 & .71 .14 .99 & .59 .15 .98 & .50 .11 .99 & .60 .17 .98 \\
\hline 75 & .74 .15 .91 & .75 .13 .99 & .63 .13 .98 & .59 .09 .99 & .65 .15 .99 \\
\hline 100 & .75 .14 .90 & .77 .12 .99 & .66 .13 .98 & .65 .08 .99 & .68 .14 .99 \\
\hline 125 & .76 .13 .91 & .78 .12 .99 & .68 .12 .98 & .69 .07 .99 & .70 .13 .99 \\
\hline
\end{tabular}


Uit tabel 13 blijkt dat uitgaande van relatieve posities van co-assistentschappen, nogal wat studenten nodig zijn voor het verkrijgen van een acceptabele betrouwbaarheid. Bij 50 waarnemingen is de betrouwbaarheid voor twee domeinen aanvaardbaar ( $G$ >.75); bij 75 waarnemingen voor vier domeinen en bij 100 waarnemingen voor vijf domeinen $(3,5,7,8,9)$. Bij de overige domeinen blijft de generaliseerbaarheidscofficiët ongeacht het aantal studenten laag. De verklaring hiervoor is dat er weinig variantie is tussen co-assistentschappen, waardoor randordening op één schaalpunt verschil niet mogelijk is. Gezien de minimale verschillen in gemiddelde domeinscores heeft dit in de praklijk ook weinig nut.

De standaardmeetfouten (SEM) zijn weergegeven in de eenheden van de oorspronkelijk schaal (viifpuntsschaal; tienpuntsschaal bij domein 13). Het blijkt dat de SEM bij 25 studenten van acceptabele grootte is en binnen het $95 \%$ betrouwbaarheidsinterval ligt.

Voor een beslissingsgerichte aanpak kan volstaan worden met 25 studenten, hetgeen aanmerkelijk minder is dan de gevonden generaliseerbaarheidscoëfficiënt. Domein 1 (voorbereiding) en domein 5 (aandacht patiënt en context) vormen hierop een vitzondering. De gemiddelde score was voor alle domeinen, met uitzondering van domein 5 (aandacht voor patiënt en context) boven de score 3 (bijlage 4). Dit betekent dat de criteriumscore ver van het gemiddelde ligt, waardoor stages met een lage score makkelijk betrouwbaar gesignaleerd kunnnen worden. Bij het merendeel van de domeinen komt hel zelfs niet voor dat de gemiddelde score beneden de criteriumscore ligt.

Op basis van deze studie kan geconcludeerd worden dat gezien de hoogte van de SEM met de vragenlijst betrouwbare scores verkregen worden over de stages. Ook is het mogelijk om extreem slechte stages te identificeren.

\subsection{Studie 7: Generaliseerbaarheid over stageplaatsen}

In deze tweede generaliseerbaarheidsstudie worden reproduceerbaarheidscofficiënten berekend, ervan uitgaande dat vitspraken gedaan worden op het niveau van de stages in ziekenhuizen. Hiervit volgl dat het object van meting de stageplaatsen zijn. Er is sprake van twee factoren: studenten genest binnen ziekenhuizen en items. Variantiebronnen kunnen berekend worden voor de hoofdeffecten: ziekenhuizen $(z)$, studenten genest binnnen ziekenhuizen $(s: z)$, items (i) en de interacties $i(s: z)$ en (zi). Er is sprake van een twee factoren design: $z \times(s: z) \times \mathrm{i}$. 


\subsubsection{Analyseprocedure}

De analyses zijn vitgevoerd per domein en per discipline. Binnen elke discipline is nagegaan voor welk ziekenhuis het kleinst aantal studentwaarnemingen beschikbaar was. Ulitgaande van dit aantal is voor alle ziekenhuizen binnen een discipline een identieke random steekproef van studenten uit het totale bestand getrokken. Hierdoor ontstond een gebalanceerd design, met een identiek aantal waarnemingen per ziekenhuis. Bijlage 5 bevat een overzicht van het aantal studenten dat gebruikt is voor de steekproeftrekking ten behoeve van de analyses. De variantiecomponenten zijn per domein voor de afzonderlijke stageplaatsen berekend en vervolgens gemiddeld, gewogen naar het aantal ziekenhuizen. De ware variantie, de relatieve errorvariantie en de absolute errorvariantie bevatten de volgende componenten:

$$
\begin{aligned}
& \hat{\sigma}^{2}(T)=\hat{\sigma}^{2} z \\
& \hat{\sigma}^{2}(\delta)=\hat{\sigma}^{2} s: z / n_{s}+\hat{\sigma}^{2} i(s: z) / n_{s} n_{i}+\hat{\sigma}^{2} z i / n_{i} \\
& \hat{\sigma}^{2}(\Delta) \quad=\hat{\sigma}^{2} s: z / n_{s}+\hat{\sigma}^{2} i / n_{i}+\hat{\sigma}^{2} i(s: z) / n_{s} n_{i}+\hat{\sigma}^{2} z i / n_{i}
\end{aligned}
$$

\subsubsection{Resultaten}

Variantiecomponenten Tabel 14 bevat de geschatte variantiecomponenten uitgesplitst per domein. 


\begin{tabular}{|c|c|c|c|c|c|c|c|c|c|c|}
\hline \multirow[b]{2}{*}{ Domein } & \multicolumn{5}{|c|}{ geschatte variantiecomponenten } & \multicolumn{5}{|c|}{$\begin{array}{l}\text { percentage van de } \\
\text { totale variantie }\end{array}$} \\
\hline & $z$ & s.z & $i$ & $i(s: z)$ & $z i$ & $z$ & $5: z$ & i & $i(s: 2)$ & $z i$ \\
\hline I Voorbereiding & .0058 & .2600 & 4671 & 4983 & .0048 & 1 & 21 & 38 & 40 & .0 \\
\hline 2 Stageboek & .0269 & 3514 & .0639 & .5022 & .2487 & 3 & 36 & 7 & 52 & 3 \\
\hline 3 Persoonsgeb. begel. & .0516 & .3469 & .0285 & .4283 & .0318 & 6 & 39 & 3 & 49 & 4 \\
\hline 4 Begel.med. techn. & .0589 & .4455 & .0753 & .5256 & .0198 & 5 & 40 & 7 & 47 & 2 \\
\hline 5 Aandacht pat.+ context & .0598 & .5538 & .0808 & .6017 & .0198 & 5 & 42 & 6 & 46 & 2 \\
\hline 7 Aanbod pat.problemen & .0827 & .4914 & .0004 & .2493 & .0074 & 10 & 59 & 0 & 30 & 1 \\
\hline 8 Patiëntgeb.leersituaties & .0159 & .2999 & .0579 & .4262 & .2076 & 2 & 37 & 7 & 52 & 3 \\
\hline o Polikliniek & .2680 & .1007 & .0728 & .5832 & .4027 & 19 & 7 & 5 & 41 & 28 \\
\hline 10 Studiefaciliteiten & .0663 & .3468 & .0314 & .4451 & .0734 & 7 & 36 & 3 & 46 & 8 \\
\hline 1) Stagebeoordeling & .0083 & .3862 & .0460 & .3886 & .0057 & 1 & 48 & 6 & 45 & 1 \\
\hline 13 Algemeen oordeel & .0989 & .6153 & .1015 & .5382 & .0698 & 7 & 43 & 7 & 38 & 5 \\
\hline$z=$ ziekenhuis, $s=$ student & $i=i t e$ & & & & & & & & & \\
\hline
\end{tabular}

Tabel 14 Overzicht van de geschatte variantiecomponenten (studie 7)

Voor het merendeel van de domeinen bestaat de grootste variantiebron uit de error. De variantiecomponenten voor s:z is relatief grool. Blijkbaar zijn er fussen studenten onderling en tussen studenten over stageplaarsen heen aanzienlijke verschillen. Bij vergelijking van de variantiecomponten over de verschillende domeinen valt de hoge ilemcomponent op voor domein 1 (voorbereiding). Dit wijst op een groot verschil in gemiddelde scores op dit item.

\section{Reproduceerbaarheid van scores}

De schattingen van de variantiecomponenten uit tabel 14 vormden de basis voor de schatting van de betrouwbaarheid en de standaardmeetfout geprojecteerd naar verschillende aantallen studenten. Het resultaat staat in tabel 15. 


\begin{tabular}{|c|c|c|c|c|c|c|}
\hline $\begin{array}{l}\text { aantal } \\
\text { studenten }\end{array}$ & $\begin{array}{l}\text { l } \\
\text { voorbe- } \\
\text { reiding } \\
\text { G SEM adi }\end{array}$ & $\begin{array}{l}2 \\
\text { stageboek }\end{array}$ & $\begin{array}{l}3 \\
\text { pers.geb } \\
\text { begeleiding } \\
\text { G SEM adj }\end{array}$ & $\begin{array}{l}4 \\
\text { begeleiding } \\
\text { med.techn. } \\
\text { G SEM adi }\end{array}$ & $\begin{array}{l}5 \\
\text { aandacht } \\
\text { pat.+cont. } \\
\text { G SEM adi }\end{array}$ & $\begin{array}{l}7 \\
\text { aanbod } \\
\text { pat.probl. } \\
\text { G SEM adj }\end{array}$ \\
\hline 5 & .05 .32 .96 & .22 .31 .99 & .37 .29 .99 & .35 .33 .99 & .33 .35 .90 & .39 .35 .00 \\
\hline 10 & .10 .23 .97 & .35 .22 .99 & .53 .21 .99 & .51 .24 .99 & .49 .25 .99 & .56 .26 .99 \\
\hline 15 & .14 .23 .97 & .43 .19 .99 & .62 .18 .99 & .60 .20 .99 & .59 .20 .99 & .65 .21 .99 \\
\hline 20 & .17 .19 .97 & .49 .17 .99 & .67 .16 .99 & .66 .17 .99 & .65 .18 .99 & .71 .19 .99 \\
\hline 25 & .20 .17 .97 & .54 .15 .99 & .71 .14 .99 & .71 .16 .99 & .70 .16 .99 & .74 .17 .99 \\
\hline 30 & .23 .15 .97 & .57 .14 .99 & .74 .13 .99 & .74 .15 .99 & .73 .15 .99 & .77 .16 .99 \\
\hline 40 & .28 .14 .97 & .62 .13 .99 & .78 .12 .99 & .78 .13 .90 & .78 .13 .99 & .81 .14 .99 \\
\hline 50 & .31 .12 .97 & .66 .12 .99 & .80 .11 .99 & .81 .12 .99 & .81 .12 .99 & .84 .13 .99 \\
\hline
\end{tabular}

\begin{tabular}{|c|c|c|c|c|c|}
\hline $\begin{array}{l}\text { aantal } \\
\text { studenten }\end{array}$ & $\begin{array}{l}8 \\
\text { pat.gebonden } \\
\text { leersituaties } \\
\text { G SEM adi }\end{array}$ & $\begin{array}{l}9 \\
\text { Golikliniek }\end{array}$ & $\begin{array}{l}10 \\
\text { studie } \\
\text { faciliteiten } \\
\text { G SEM adj }\end{array}$ & $\begin{array}{l}11 \\
\text { stage } \\
\text { beoordeling } \\
\text { G SEM adi }\end{array}$ & $\begin{array}{l}13 \\
\text { algemeen } \\
\text { oordeel } \\
\text { G SEM adi }\end{array}$ \\
\hline 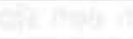 & & 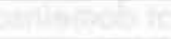 & 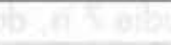 & 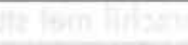 & 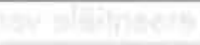 \\
\hline 5 & .12 .34 .99 & .49 .53 .97 & .35 .35 .99 & .07 .32 .99 & .35 .43 .97 \\
\hline 10 & .20 .25 .99 & .53 .49 .97 & .47 .27 .99 & .14 .23 .99 & .49 .32 .98 \\
\hline 15 & .26 .21 .99 & .54 .48 .97 & .54 .24 .99 & .18 .19 .99 & .56 .28 .99 \\
\hline 20 & .31 .19 .99 & .55 .47 .97 & .57 .22 .99 & .23 .16 .99 & .61 .25 .99 \\
\hline 25 & .34 .18 .99 & .55 .46 .97 & .60 .21 .99 & .27 .15 .99 & .64 .23 .99 \\
\hline 30 & .37 .17 .99 & .56 .46 .97 & .62 .20 .99 & .31 .14 .90 & .67 .22 .99 \\
\hline 40 & .41 .15 .99 & .56 .46 .97 & .64 .19 .99 & .36 .12 .99 & .70 .21 .99 \\
\hline 50 & .44 .14 .99 & .56 .46 .97 & .66 .19 .99 & .41 .11 .99 & .72 .20 .99 \\
\hline
\end{tabular}

Reproduceerbaarheid van scores bij verschillende aantallen studen- Tabel 15 ten voor normgeoriënteerde interpretatie (generaliseerbaarheidscoëfficiënt: G), bijbehorende standaardmeeffouten (SEM) en beslissingsgericht perspectief (adjusted phi-coëfficiënt)

Uit tabel 15 blijkt dat uitgaande van een relatieve positie van ziekenhuizen, nogal wat studenten nodig zijn voor het verkrijgen van een acceptabele betrouwbaarheid. Bij 30 waarnemingen is de betrouwbaarheid voor een domein van een aanvaardbaar niveau; bij 40 warnemingen in totaal voor vier domeinen $(3,4,5,7)$. Voor de overige domeinen zijn aanmerkelijk meer waarnemingen nodig. Blijkbaar zijn de verschillen voor een aantal domeinen zo 
minimaal, dat rangording op basis op éen schaalpunt verschil onmogeliịk is. De standaardmeetfouten zijn weergegeven in de eenheden van de oorspronkelijke schaal. Het blijkt dat de SEM bij 10 studenten van acceptabele grootte is en binnen het $95 \%$ betrouwbaarheidsinterval ligt. Een vitzondering hierop vormt domein 9 (polikliniek) en domein 10 (studiefaciliteiten). Bii een beslissingsgerichte aanpak kan volstaan worden met viff studenten, hetgeen aanmerkelijk minder is dan bij de generaliseerbaarheidscoëfficiënt. In bijlage $\sigma$ is een overzicht van de gemiddelde scores opgenomen. Het blijkt dat de gemiddelde domeinscores over het geheel genomen boven de grenswaarde (3) liggen. Indien een stageplaats een lage score heeft, kan dit makkelijk gesignaleerd worden. Op basis van deze studie kan geconcludeerd worden dat gezien de hoogte van de SEM met de vragenlijst betrouwbare scores over stageplaatsen verkregen worden. Ook is het mogelijk om extreem slechte stageplaatsen te identificeren.

In hoofdstuk 6 is gesteld dat van elk stageplaats een sterktezwakte analyse gemaakt wordt middels een profiel. Dit profiel geeft per domein de gemiddelde scores en maakt het mogelijk de domeinscores van een stageplaats onderling te vergelijken. Het essentiële verschil met studie 7 is, dat domeinscores binnen een siageplaats vergeleken worden en niet met andere stageplaatsen. Het perspectief van interpretalie is dus anders. Studie 8 gaat hierop nader in.

\subsection{Studie 8: Generaliseerbaarheid over stageplaats}

In de derde generaliseerbaarheidsstudiestudie worden de reproduceerbaarheidscoëfficiënten berekend, ervan uitgaande dat uitspraken gedaan worden op het niveau van de stageplaats. Hieruit volgt dat het object van meting de domeinen zijn. We zijn geinteresseerd naar kwaliteitsverschillen binnen stages middels stageprofielen. Er is een factor: studenten. De domeinen zijn gekruist met studenten, omdat hier dezelfde groep studenten alle domeinen van een stageplaats beoordeeld heeft. Variantiebronnen worden berekend worden voor de hoofdeffecten: domeinen (d) en studenten (s) en het interactieffect (ds). Dit resulteert in een één factor model: $d x s$.

\subsubsection{Analyseprocedure}

De analyses zijn uitgevoerd per stageplaats over alle domeinen. Binnen elke stageplaats is nagegaan welk domein het kleinst aantal waarnemingen had. Hiervan uitgaande is voor alle domeinen binnen een stageplaats een identieke random steekproef van studenten 
vit het totale bestand getrokken. Hierdoor ontstond een gebalanceerd design. Bijlage 7 bevat een overzicht van het aantal studenten dat gebruikt is voor de steekproeftrekking ten behoeve van de analyses. De variantiecomponenten zijn voor de afzonderlijke stageplaatsen berekend en vervolgens gemiddeld om een schatting van het totale effect te krijgen. Ter vergelijking van alle domeinen onderling, is voor alle domeinen vitgegaan van een viffpuntsschaal. Dit belekent dat de scores van domein 13 (algemeen oordeel) voor dit doel zijn omgezet in een vijfpuntsschaal. Berekening vanuit een beslissingsgericht perspectief is in deze studie niet aan de orde, omdat dit dezelfde uitkomsten geeft als studie 7. De ware variantie en de relatieve errorvariantie bevatten de volgende variantiecomponenten.

$$
\begin{aligned}
& \hat{\sigma}^{2}(T)=\hat{\sigma}^{2} d \\
& \hat{\sigma}^{2}(\delta)=\sigma^{2} d s / n_{s}
\end{aligned}
$$

\subsubsection{Resultaten}

Variantiecomponenten

Tabel 16 bevat de geschatte variantiecomponenten.

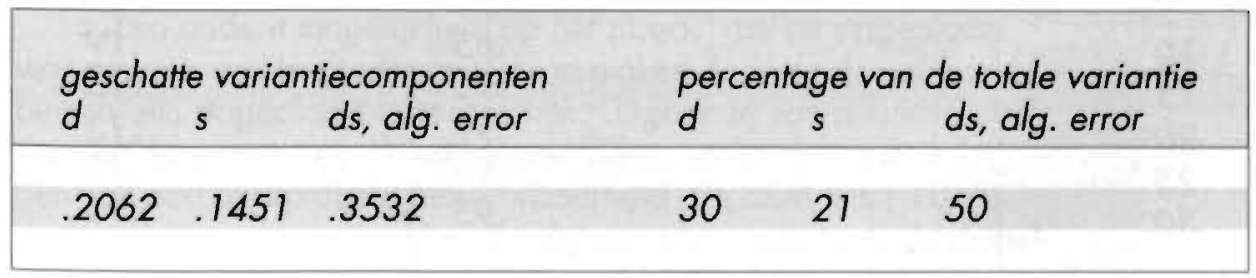


De variantie voor het interactieëfect en algemene error is het grootst. De variantie voor de domeinen is relatief hoog. Blijkbaar is er verschil tussen de gemiddelde scores van de domeinen. Dit betekent dat er weinig waarnemingen nodig zullen zijn om beslissingen te nemen over zwakke domeinen.

\section{Reproduceerbaarheid van scores}

De schattingen van de variantiecomponenten uit label 16 vormden de basis voor de schatting van de betrouwbaarheid en standaardmeetfout, geprojecteerd naar verschillende aantallen studenten.

Uit tabel 17 blijkt dat uitgaande van relatieve posities van domeinen, 10 studenten nodig zijn voor het verkrijgen van een acceptabele betrouwbaarheid. Dit maakt rangordening van domeinen mogelijk. De SEM is bij 10 studenten eveneens van acceptabele grootte. Op basis van deze studie kan geconcludeerd worden dat met 10 waarnemingen per stageplaats een sterkte-zwakte-analyse gemaakt kan worden, waarbij rangordening van domeinen binnen een stageplaats tot de mogelijkheden behoort. Uit studie 7 bleek reeds dat vanuit een beslissingsgerichte benadering op basis van 5 studenoordelen eveneens betrouwbare beslissingen genomen kunnen worden ten aanzien van domeinen die onvoldoende beoordeeld worden.

Tabel 17 Reproduceerbaarheid van scores bij verschillende aantallen studenten voor normgeoriënteerde interpretatie (generaliseerbaarheidscoëfficiënt: G), en biibehorende standaardmeetfouten (SEM)

\begin{tabular}{|lll|}
\hline aantal studenten & G-coëfficiënt & SEM \\
\hline & & \\
\hline 5 & .74 & .26 \\
10 & .85 & .19 \\
15 & .90 & .15 \\
20 & .92 & .13 \\
25 & .94 & .12 \\
30 & .95 & .11 \\
\hline
\end{tabular}




\subsection{Algemene conclusie}

Uitspraken over stages (niveau 1) gebaseerd op relatieve posities van co-assistentschappen, vragen om grote aantallen studenten. Bii 100 waarnemingen is voor 5 domeinen de generaliseerbaarheidscoëfficiënt van een aanvaardbaar niveau. Bij de overige domeinen bliift de generaliseerbaarheidscoëfficiënt laag, ongeacht het aantal studenten. Het aanbrengen van een rangorde in stages op basis van re subtiele verschillen wordr dan ook afgewezen. Uitspraken op één schaalwaarde verschil zijn daarentegen wel mogelijk, gezien de standaardmeetfout. Aan de standaardmeetfout dient meer waarde worden te gehecht, omdat deze een indicatie geeft van de betrouwbaarheid van de scores. De SEM is bij 25 studenten van acceptabele grootte. Voor een beslissingsgerichte aanpak ter signalering van stages met extreem lage domeinscores, kan eveneens volstaan worden met 25 studenten. De vitspraken op dit niveau hebben betrekking op de stages in totaliteit en zijn daardoor zeer globaal. Deze informatie is voor beleidsdoeleinden bruikbaar, omdat deze een indicatie geeft welke stages op bepaalde aspecten aandacht verdienen, bijvoorbeeld de voorbereiding ten aanzien van de stage dermatologie. Voor stagecoördinatoren is meer gerichte informatie gewenst. Hierover geven de analyses voor de stageplaatsen (niveau 2) vitsluitsel.

Uitspraken over stages gebaseerd op relatieve posities van stageplaatsen binnen een discipline, zijn voor de domeinen $3,4,5$ en 7 bij 40 studentoordelen per stageplaats mogelijk. Voor de overige domeinen bliift de G-coëfficiënt laag. Hiervit volgt dat rangordening van stages bij verschillen van $<1$ niet mogelijk is. Bij een verschil van één schaalwaarde is dit wel mogelijk, gezien de standaardmeetfout. De SEM is bij $\theta$ studentoordelen van acceptabele grootte. Een uitzondering hierop vormt domein 9 (polikliniek) en domein 10 (studiefaciliteiten). Dit is een indicatie dat de kwaliteit van de polikliniek en studiefaciliteiten afhankelijk zijn van de stageplaats. Vanuit een beslissingsgerichte aanpak ter signalering van extreem slechte stageplaatsen zijn 5 waarnemingen voldoende voor een acceptabele betrouwbaarheid. Uit de gemiddelde scores blijkt dat het zelden voorkomt dat een stageplaats een lage score behaalt voor een domein alleen.

Een andere mogelijkheid op het niveau van de stageplaats was om een sterkte-zwakte-analyse te maken door de domeinscores binnen een stageplaats te vergelijken. Uitgaande van relatieve posities van domeinen, zijn 10 studentoordelen nodig voor het verkriigen van een acceptabele betrouwbaarheid. De SEM is bij 10 studentoordelen voldoende. Hieruit volgt dat per stageplaats de domei- 
nen betrouwbaar geordend kunnen worden. Op basis hiervan kan elke coördinator aangeven welke aspecten binnen de stageplaats prioriteit hebben wat betreft kwaliteitsverbetering. Tabel 18 geeft een overzicht van de resultaten.

Tabel 18 Overzicht van het aantal studenten dat nodig is om op de diverse niveaus vanuit verschillende perspectieven uitspraken te doen

\begin{tabular}{|c|c|c|c|}
\hline Uitspraken & G-coëfficiënt & SEM & Adjusted phi-coëfficiënt \\
\hline $\begin{array}{l}\text { Niveau } 1 \\
\text { stages }\end{array}$ & $\begin{array}{l}50: \text { d. } 3-7 \\
75: \text { d. } 5-9 \\
100: \text { domein } 8\end{array}$ & 25 & 25 \\
\hline $\begin{array}{l}\text { Niveau } 2 \\
\text { stageplaatsen } \\
\text { binnen een discipline }\end{array}$ & $\begin{array}{l}30: \text { d. } 7 \\
40: \text { d. } 3-4-5\end{array}$ & 10 & 5 \\
\hline $\begin{array}{l}\text { Sterkte en zwakte } \\
\text { analyse van een } \\
\text { stageplaats }\end{array}$ & 10 & 10 & * \\
\hline
\end{tabular}


Wat betekenen de resultaten voor de metingen die tot op heden hebben plaatsgevonden? Per jaar lopen gemiddeld 130 studenten stage per discipline. Deze studenten worden verdeeld over diverse ziekenhuizen. Dit betekent een aantal van 12-60 studenten per stageplaats, afhankelijk van de capaciteit van de betreffende ziekenhuizenafdeling. Tot op heden werd alle studenten verzocht een vragenlijst in te vullen aan het einde van de stage. Uitgaande van een respons van $80 \%$ betekent dit dat per stagediscipline ongeveer 100 vragenlijst werden ingevuld en per stageplaats $10-50$ vragenlijsten. Deze gegevens zijn de laatste jaren gebruikt om uitspraken te doen over de kwaliteit van stages en stageplaatsen en op grond daarvan aanbevelingen te formuleren ter kwaliteitsverbetering. Op basis van de uitgevoerde studies kan geconcludeerd worden dat bij deze aantallen studenten betrouwbare metingen verricht zijn en verantwoorde beslissingen genomen zijn. Zeker als we hierbij bedenken dat de variabele "items" in deze studie als een random variable is opgevat. Zoals reeds eerder betoogd, hebben we bij de stage-evaluatie voor de "kwetsbaarste" opstelling gekozen, zodat de betrouwbaarheidscoëfficiënten eerder een onderschatting dan een overschatting van de werkelijk zijn. In andere soortgelijke (bijvoorbeeld Gijselaers, 1988; Feldman, 1977) worden items uit vragenlijsten veelal als fixed variabele opgevat.

Is het mogelijk de dataverzameling in de toekomst efficiënter op te zetten met behoud van betrouwbaarheid? Uit deze studies blijkt dat de G-coëfficiënt aan de lage kant is. De SEM en de adjusted-phi-coëfficiënt zijn reeds bii beperkte aantallen studenten acceptabel. Daarom zou volstaan kunnen worden mel minder studentoordelen. Een aantal van tenminste 10 studentoordelen per stageplaats is voldoende om betrouwbare uitspraken te kunnen doen op het niveau van de stageplaats. Uitgaande van vier stageplaatsen geeft dit de beschikking over 40 studentoordelen per discipline. Dit aantal is eveneens voldoende om betrouwbare uitspraken op het niveau van de discipline te doen. Uiteraard is het belangrijk dat een at-random groep studenten gevraagd wordt om de lijsten in te vullen, zodat de steekproef representatief is voor de populatie co-assistenten.

\subsection{Samenvatting}

Na een inleiding over methode en analysevorm en vraagstelling van onderzoek geeft dit hoofdstuk een beschrijving van drie studies naar de betrouwbaarheid van het instrument, uitgaande van de generaliseerbaarheidstheorie. Het doel van deze studies is tweeledig. Ten 
eerste om een indicatie te krijgen van de betrouwbaarheid van de scores en van beslissingen die genomen worden met behulp van het instrument. Ten tweede om om vast te stellen hoeveel waarnemingen van studenten nodig zijn om tenminste een betrouwbaar oordeel te kunnen geven door het aantal studenten te variëren. Interpretalie van de scores gebeurt vanuit een relatiefgeoriënteerde benadering en een beslissingsgerichre benadering. Een relatiefgeoriënteerde benadering gaat bij de interpretatie van gegevens uit van onderlinge verschillen tussen stages. Een beslissingsgerichte benadering geeft aan of een score onder de kritieke grens ligt. De schatting van de betrouwbaarheidsindices heeft vanuit beide benaderingen plaatsgevonden. De uitgevoerde drie studies hebben betrekking op het niveau van de stage én de stageplaats. De resultaten wijzen uit dat het instrument betrouwbare metingen mogelijk maakt op alle niveaus van interpretatie. In de toekomst zou derhalve met behoud van betrouwbaarheid, met minder waarnemingen volstaan kunnen worden. 


\section{Discussie en conclusies}

Het aanwenden van evaluatiegegevens om onderwijs te verbeteren binnen klinische stages staat nog in de kinderschoenen. Er ziin slechts enkele studies bekend waarbij evaluatiegegevens expliciet gebruikt zijn bij de inrichting van deze stages. Voorbeelden hiervan zijn de studie van Bouhuijs (1983) naar de inrichting van de stage huisartsgeneeskunde en de studie van Van Rossum (1977) naar de inrichting van de stage gynaecologie/obstetrie. De laatste jaren is een toenemende aandacht voor het evalueren van stages. Op diverse universiteiten zijn aanzetten om een systematische stage-evaluatie te realiseren, maar vaak blijft het gewenste effect achterwege. De visitatiecommissie geneeskunde maakt in haar eindrapportage melding van problemen die optreden bij de interne kwaliteitszorg zoals de geringe respons van studenten, het ontbreken van procedures die borg staan voor de vertaling van evaluatiegegevens naar de prakrijk, het ontbreken van continuiteit in de evaluatie en een gebrek aan communicatie fussen betrokkenen (VSNU, 1992).

De vraag is waarom het evalueren van klinische stages over het geheel genomen nationaal en internationaal onvoldoende van de grond komt. De verklaring hiervoor moet wellicht in de geschiedenis van het medisch onderwijs gezocht worden. Hoofdstuk 2 beschrijt dat tol aan hel begin van deze eeuw de opleidingen tot arts georganiseerd was volgens het meester-gezel principe, waarbij de gezel in de loop van de leerperiode de praktische bekwaamheid van de meester verwierf. De stage viel niet onder directe verankwoordelijkheid van de faculteit maar was een aangelegenheid van de individuele hoogleraar, die vrijwel autonoom kon handelen (Goudsmit, 1978). De arts-opleiders duldden geen inmenging en er was weinig overleg met de faculteit. Externe evaluatie was dan ook ondenkbaar. Een andere verklaring legt verband met de setting van ziekenhuizen waarbinnen stages plaatsvinden. Een ziekenhuis kan gekarakteriseerd worden als een dynamische werkomgeving, waarin werkzaamheden voor een groot deel momentgebonden, onvoorspelbaar en bovendien sterk afhankelijk van het patiëntenaanbod zijn. Hierdoor wordt planning en structurering van werkzaamheden bemoeilijkt. De combinatie van de autonomie van de arts-opleider 
en de dynamiek van de onderwijsomgeving leidt tot de veronderstelling dat een systematische evaluatie van klinische stages niet haalbaar zou zijn. Deze opvatting kan op basis van de studies, die in dit proefschrift gepresenteerd worden, verworpen worden. Met behulp van een vragenlijst voor studenten, die identiek is voor alle stages, wordt informatie verzameld over de kwaliteit van klinische stages. De vragenlijst bestaat voor het merendeel uit gesloten vragen die voorzien zijn van een vijfpunts-ofwel Likertschaal. De items hebben betrekking op inhoudelijke domeinen, die een operationalisatie zijn van de voorwaarden waaraan stages moeten voldoen. Studenten vullen aan het einde van elke stage deze vragenlijst in. Op basis van de antwoorden van de studenten wordt voor elk domein een gemiddelde scores berekend, onderscheiden noar stage en stageplaats. Deze domeinscores geven een indicatie van sterke en zwakke punten van een stage en vormen de basis om beslissingen te nemen voor eventuele veranderingen ter kwaliteitsverbetering van de stage. De beschreven praktijkvoorbeelden in hoofdstuk 7 illustreren dat met behulp van dit instrument gegevens verkregen worden die een basis kunnen zijn voor het aanbrengen van dergelijke gerichte veranderingen.

De vraag is dan waarom evalualie van stages aan de Faculteit der Geneeskunde van de Rijksuniversiteit Limburg wel haalbaar blijkt. In hoofdstuk 4 hebben we geconstateerd dat vanaf de oprichting in 1974 is getracht het onderwijs zo rationeel mogelijk vorm te geven. Bij stages is getracht de autonomie van de individuele opleider te doorbreken door meerdere mensen verantwoordelijk te maken voor de stages door middel van de instelling van planningsgroepen en overlegorganen op het niveau van de disciplines, de ziekenhuizen en de faculteit. Daarnaast zijn er maatregelen getroffen om het onderwijs planmatig te laten verlopen, bijvoorbeeld door het aanstellen van slagecoördinatoren, het gebruik van stageboeken, een uniforme structuur, het streven naar eenduidige toetsvormen en afspraken over onderwijsactiviteiten. Het resultaat hiervan is dat de stages van de Medische Faculteit Maastricht in redelijke mate controleerbaar en beheersbaar zijn. Bovendien worden stages beschouwd als een essentieel onderdeel van de opleiding, dat onder verantwoordelijkheid valt van de faculteit, maar waarvan de vitvoering gedelegeerd is aan de ziekenhuizen. We hebben dat een "rationalistische" organisatie genoemd, waarbij verantwoordelijkheden van artsdocenten omschreven zijn. Hiermee wordt onderschreven dat evaluatie meer kans van slagen heeft in onderwijsorganisaties waaraan een rationalistisch model ren grondslag ligt (DarlingHammond et al., 1983; Gijselaers, 1988\}

Het doel van stage-evaluatie is om slerke en zwakke punten 
van de stages vast te stellen en een basis te verschaffen om veranderingen te bewerkstelligen. Dit proefschrift beschrijft de constructie van een instrument, dat de vorm heeft van een vragenlijst, die studenten aan het einde van elke stage invullen. Ten behoeve van de constructie is een omschrijving gemaakt van wat onder de kwaliteit van een stage verstaan wordt. Zoals in hoofdstuk 4 is beschreven kan aan het begrip kwaliteit invulling worden gegeven vanuit een procesgerichte en/of vanuit een produktgerichte invalshoek. Een procesmatige benadering richt zich op de voorwaarden waaronder leren plaalsvindt. Een produkigerichte benadering legt het accent op het vaststellen van de beoogde leereffecten. In deze studie is gekozen voor een procesgerichte benadering, waarbij kwaliteit is geoperationaliseerd in termen van randvoorwaarden ofwel vormkenmerken waaraan klinische stages moeten voldoen. Dit heeft geresulteerd in 14 inhoudelijke domeinen, die vertaald zijn in items. Het betreft de volgende domeinen: de voorbereiding van de student op de stage, de kwaliteit van de informatie die studenten ontvangen over de inhoud en de opzet van de stage, de kwaliteit van de persoonsgebonden begeleiding, de kwaliteit van de medisch-technische begeleiding, de aandacht voor patiënt en context, de kwaliteit van onderwijsactiviteiten, het aanbod van patiëntproblemen, de kwaliteit van patiëntgebonden leersituatiës, de kwaliteit van de polikliniek, de kwaliteit van studiefaciliteiten, de kwaliteit van stagebeoordeling, de gelegenheid tot zelfstudie, de tijdsbesteding tijdens de stage en het algemeen oordeel van de stage. Kwaliteit is niet benaderd vanuit een produktgerichte benadering omdat bij een dergelijke benadering geen indicatie verkregen wordt over "wat" mankeert aan het onderwijs. Bovendien ontbreekt het aan betrouwbare indicatoren - toetsen - om het effect van medisch onderwijs vast te stellen. De constructie van valide toetsen die een operationalisering zijn van de beoogde doelen van een słage is momenteel sterk in ontwikkeling. Het gebrek aan zulke toetsen komt mede doordat doelstellingen in het praktisch medisch onderwijs onderbelicht zijn waardoor een basis ontbreekt voor de contructie. De gedachte heerst veelal dat het formuleren van doelen overbodig zou zijn. Betrokken partijen menen op de hoogte te zijn van de doelen van klinische stages, waardoor een verdere discussie over de inhoud van de opleiding achterwege blijt. Deze opvatting vindt eveneens haar verdere wordels in de geschiedenis van het medisch onderwijs waarbij arts-docenten vrij autonoom konden handelen en wisten wat goed voor een student zou zijn. Doelstellingen leken enerzijds onmogelijk door het sterk fluctuerende patiëntenaanbod en werden anderzijds overbodig geacht. Abrahamson (1989) verwoordt dit op uitstekende wijze aan de hand van wat hij omschrijft als een mythe: "our educational 
goals are clear to us and to our students". Echter deze gedachte verliest terrein. In Maastricht zijn reeds voor het merendeel van de stages doelen geformuleerd. Op landelijk niveau (BOC-project) ziet men al meer de trend om de beoogde leereffecten in kaart te brengen (Metz, Bulte \& Paridon, 1990). Ook in Maastricht zijn er casestudies uitgevoerd waarbij de haalbaarheid van doelstellingen op disciplineniveau nader wordt bekeken (Wolfhagen et al., 1992; Schaper et al., 1992). Deze studies wijzen uit dat er geen volledige overeenstemmming is over de doelen van een stage, maar dat het tot de mogelijkheden behoort om tot een nadere concretisering te komen. Gezien deze ontwikkelingen is het in de nabije toekomst niet ondenkbaar dat kwaliteit zowel vanuit een procesgerichte als vanuit een produktgerichte benadering onderzocht kan worden.

Informatie over de kwaliteit van stages kan bij diverse groepen verzameld worden. Mogelijke respondenten zijin ; artsen, bestuurders van de faculteit, externe deskundigen en studenten. Artsbegeleiders en studenten hebben als voordeel dat ze beiden als "directe" participanten van het onderwijs beschouwd kunnen worden. Het oordeel van bestuurders en externe deskundigen (bijvoorbeeld visitatiecommissies) zal altijd indirect zijn omdat zij op afstand betrokken zijn bij het onderwijs en voor hun oordeelsvorming grotendeels afhankelijk zullen zijn van informatie van derden. Uit onderzoek blijkt dat studenten zeer wel in staat zijn onderwijs op hun merites te beoordelen (Giiselaers, 1988; Marsh, 1984; Stillman, 1983). Er is weinig onderzoek bekend waarin op grote schaal gebruik gemaakt word van oordelen van docenten om de kwaliteit van stages te beoordelen. Dit neemt niet weg dat andere respondentgroepen eveneens in staat zijn om bruikbare informatie te leveren over de kwaliteit van stages, Afhankelijk van het soort betrokkenheid zullen personen mogelijkerwijs de kwaliteit anders beoordelen. Eventuele discrepanties in oordelen tussen diverse respondentgroepen zouden onderwerp van discussie moeten zijn en desgewenst moeten resulteren in verder onderzoek. Het is bijvoorbeeld denkbaar dat studenten vinden voldoende voorbereid te zijn op de stage wat betreft hun kennis en hun vaardigheden, terwijl de arts-begeleiders een andere mening zijn toegedaan. De vraag is dan wat de verklaring is voor deze discrepantie. Om hierover een uitspraak te kunnen doen, is nader explicitering van de voorkennis vereist. Vervolgens kan nagegaan worden in hoeverre de eisen van de opleiders en studenten overeenkomen met dalgene wat op grond van de vooropleiding verwacht mag worden van studenten. Afhankelijk van de uitkomst daarvan zou dit kunnen leiden tot bijstelling hetzij van de eisen aan de zijde van de artsen of hetzij veranderingen van het voorafgaande curriculum (Schaper et al. 1992; Scherpbier et al. 1992). 
Het is van belang om allen die betrokken zijn bij de realisering van stages zoveel mogelijk in te schakelen bij de opzet en vitvoering van de evaluatie ervan. Uit innovatiestudies (Dalin, 1987; Fullan, 1982) is bekend dat een sterke betrokkenheid bevordert dat evaluatiegegevens ook daadwerkelijk vertaald worden in concrete acties en resulteren in het gewenste effect. Hoofdstuk 5 beschrifft op welke wijze gepoogd is om zoveel mogelijk participanten van stages in te schakelen bij de evaluatie. Allereerst is bij de constructie van het instrument een beroep gedaan op de inbreng van studenten, bestuurders en arts-begeleiders. Ten tweede is benadrukt dat zowel artsen, bestuurders als studenten belang hebben bij kwalitatief goede stages en daarom zorg dienen te dragen voor het creëren van voorwaarden die het invullen van de vragenlijsten bevorderen. Ten derde worden evaluatierapporten op zowel beleids- als uitvoerendniveau besproken. Tijdens dergelijke bijeenkomsten krijgen alle partijen de gelegenheid om hun visie te geven en wordt bij het treffen van maatregelen rekening gehouden met verschillende standpunten. De studies in hoofdstuk 7 onderschrijven het belang van betrokkenheid bij de stage-evaluatie. Een van de beschreven studies illustreert dat veranderingen waar opleiders niet voldoende achter staan weinig kans van slagen hebben. In een dergelijk geval ontbreekt de motivatie om maatregelen te nemen. Hieruit volgt dat het van essentieel belang is om op de hoogte te zijn van aspeclen die de betrokkenen zelf binnen een słage belangrijk vinden. Dergelijke informatie kan gebruikt worden bij het opstellen van actieplannen. In dit kader heeft aan de Medische Faculteit Maastricht een exploratieve studie plaatsgevonden. Een van de doelen hiervan was om meer inzicht te krijgen in de eisen die arts-begeleiders, bestuurders en studenten stellen aan de stagebegeleiding (Wolfhagen et al., 1992). Op basis van de resultaten van deze studie kan ondermeer geconcludeerd worden dat er verschillen zijn fussen datgene waar studenten, bestuurders en artsen de meeste waarde aan hechten. Deze informatie is zeer bruikbaar, wanneer blijkt dat de begeleiding naar het oordeel van studenten onvoldoende is en gezocht moet worden naar mogelijkheden om de begeleiding te verbeteren. Uitbreiding van dergelijk onderzoek naar de eisen die artsen, bestuurders en studenten stellen aan de diverse aspecten van slages zou zeer zinvol zijn, bijvoorbeeld ten aanzien van de eisen die aan een werkplek gesteld zouden moeten worden en/of aan de stagebeoordeling.

Tegenstanders van het systematisch evalueren van stages gebruiken hiervoor wel eens het argument dal stages plaatsvinden in een relatief ongestructureerde omgeving. Dit impliceert dat elke stage uniek is en ervaringen van studenten sterk persoonsgebonden 
zijn. Gesuggereerd wordt dat het daarom mogelijk is om tot een valide en betrouwbaar eindoordeel per stageplaats te komen. De resultaten van de onderhavige studie geven een duidelijke indicatie dat evaluatie ook in minder gestructureerde onderwijssituaties haalbaar is. De validiteit van het meetinstrument is onderzocht door met behulp van toetsende factoranalyse (LISREL) na te gaan in hoeverre de op inhoudelijke en pragmatische gronden gespecificeerde structuur ook empirisch waarneembaar is. Bovendien is nagegaan in hoeverre het construct dat aan hel instrument ten grondslag ligt over opeenvolgende jaren stabiel is. De resultaten van deze studies zoals beschreven in hoofdstuk 8 tonen aan dat de constructualiditeit van het instrument meer dan redelijk is. Met behulp van de generaliseerbaarheidstheorie is nagegaan of met het instrument betrouwbaar gemeten kan worden en op grond van deze metingen betrouwbare vitspraken gedaan kunnen worden. De resultaten in hoofdstuk 9 wijzen uit dat ondanks de diversiteit van stageplaatsen met relatief weinig studentoordelen - 10 per stageplaats - betrouwbare metingen en vitspraken gedaan kunnen worden. Blijkbaar zijn er in alle stages elementen waarneembaar waarover voldoende eenduidige meningen bestaan. Studies die zijn uitgevoerd naar de beoordeling van docenten in meer gestructureerde onderwijssituaties, bijvoorbeeld in colleges en onderwijsgroepen, rapporteren dat de betrouwbaarheid van gemiddelde studentoordelen - gebaseerd op 10 studenten varieert tussen .70 en .75 (Feldman, 1977; Gijselaers, 1988; Marsh, 1982). De resultaten van de onderhavige studies naar de meeteigenschappen van het instrument vormen dus een indicatie dat ook in minder gestructureerde settings zoals stages systematisch geëvalueerd kan worden.

Ondanks de inzet van stagecoördinatoren om evaluatie te vertalen in concrete maatregelen en resultaten zichtbaar te maken, blijft het gewenste effect toch vaak achterwege. Een eerste verklaring voor dit fenomeen moet gezocht worden in het feit dat evaluatiegegevens vaak van indirecte betekenis zijn. Evaluatiegegevens fungeren in eerste instantie binnen de diverse platforms als aanzet voor een discussie, zonder hoofdzakelijkerwijs uit te monden in voorstellen voor concrete veranderingen. De discussie richt zich bijvoorbeeld op vragen als: "waarom wordt de begeleiding onvoldoende beoordeeld door studenten?", "wat voor eisen stellen studenten aan de begeleiding?", "zijn deze eisen haalbaar?", "hoe wordt door de artsen gedacht over de wijze waarop de begeleiding zou moeten plaatsvinden?". Dergelijke vragen zijn aanleiding om na te gaan hoe de begeleiding er vit zou moeten zien, en leiden vaak tot uitwisseling van gedachten tussen de arts-begeleiders. In een later stadium resulteert dit soms in concrete voorstellen voor ver- 
andering. Het effect van programma-evaluatie is dus in een dergelijk geval indirect. Deze manier van omgaan met evaluatiegegevens vertoont onvereenkomsten met het onderscheid dat Cooley en Bickel (1986) maken in instrumenteel versus conceptueel gebruik van evaluatiegegevens. Instrumenteel gebruik verwijst naar situaties waarin de resultaten expliciet betrokken worden in de besluitvorming. Met conceptueel gebruik wordt bedoeld dat evaluatiegegevens van invloed zijn op de gedachtengang van personen die geacht worden beslissingen te nemen zonder dat de beslissing het directe resultaat hoeft te zijn van de gepresenteerde evaluatieve informatie. Het oproepen van een discussie naar aanleiding van evaluatiegegevens kan als een eerste stap in de richting van kwaliteitsverbetering beschouwd worden. Een tweede verklaring is gelegen in het feit dat onderwijs niet bij alle artsen hoge prioriteit heeft. In ziekenhuizen hebben artsen veelal een onderwijs-, onderzoeks- en patiëntenzorgtaak. Dit leidk tot een voor het onderwijs niet altijd even gunstig prioriteitsstelling. Schretlen (1981, p. 1097) typereert deze situatie als volgt: "Het onderwijs in de geneeskunde staat vaak in de schaduw van de patiëntenzorg en medische research; de relatief geringe belangstelling hiervoor weerspiegelt de waarde die eraan gehecht wordt". Uiteraard geldt dit niet voor alle klinische docenten. Een van de gevolgen van deze prioritering is dat onderwijsactivifeiten zich vaak in één persoon concentreren. Personen die sterke affiniteit voelen met onderwijs, vertegenwoordigen de afdeling in de planningsgroepen waar de de resultaten van de stage-valuatie besproken worden. De bedoeling is dat de vertegenwoordigers in de planningsgroepen hun collega"s vervolgens informeren en overtuigen van het nut van bepaalde veranderingen. Het verwachte effect hiervan blift vaak achterwege omdat de achterban onvoldoende binding voelt met onderwijs, andere proriteiten heeft en daardoor minder genegen is bepaalde wijzigingen door te voeren. Dit verklaart waarom bepaalde voorstellen tot veranderingen geen of onvoldoende ingang vinden en dus niet slagen. Daarom zou bij artsen een attitude ontwikkeld moeten worden, waaruit blijkt dat onderwijs aan toekomstige collegae belangrijk is en een taak van allen. Met name bij klinische stages is het belangrijk dat het hele afdelingsteam betrokken is bij onderwijs. Impliciet is de aanname dat elke arts, die bekwaam is op het gebied van de patiëntzorg en research, ook in staat is studenten te begeleiden. In de praktijk blijken deze capaciteiten niet altijd samen te gaan. De begeleiding wordt door artsen gegeven, die veelal niet didaclisch geschoold zijn. Ook begeleiden vraagt specifieke deskundigheid. Het is dan ook opmerkelijk dat binnen opleidingsziekenhuizen weinig gedaan wordt aan de didactische scholing van artsen. Om het belang van onderwijs te onder- 
strepen zou het aanbeveling verdienen curcussen te organiseren, die leiden tot een verdere professionalisering van de begeleiders. Hiermee geeft de instelling aan dat begeleiden speciale vaardigheid vereist en dat waarde gehecht wordt aan deskundige opleiders.

Op basis van de resultaten van het hier gepresenteerde onderzoek lijkt het gerechtvaardigd om te stellen dat systematische evaluatie van klinisch onderwijs mogelijk is en bovendien bruikbare informatie biedt om de kwaliteit van stages te bewaken en te bevorderen. 


\section{SAMENVATTING}

Het thema van dit proefschrift is de ontwikkeling van een systeem voor kwaliteitszorg van het klinisch onderwijs, dat wil zeggen de praktisch-medische stages/co-assistentschappen in ziekenhuizen. In Hoofdstuk 1 staat de context waarbinnen deze studie verricht is centraal en komt de vitwerking van de probleemstelling aan de orde. Ook binnen het universitaire onderwijs is er een toenemende belangstelling voor de kwaliteit van het onderwijs. Dit komt met name door een aantal maalregelen (HOAK, 1985; HOOP, 1987) van het ministerie van Onderwijs en Wetenschappen waarbij de universiteiten gevraagd wordt verantwoording af te leggen over de kwaliteit van hun onderwijs. Een logisch gevolg van deze vraag naar informatie is dat binnen het hoger onderwijs behoefte was aan systemen die dit mogelijk zouden maken. Aan de Rijksuniversiteit Limburg werd al geruime tijd voordat de kwaliteitszorg van onderwijs in Nederland actueel werd, gewerkt aan de ontwikkeling van systemen voor kwaliteitszorg. De redenen hiervoor zijn dat deze faculteit relatief jong is en een onderwijsstrategie - probleemgestuurd leren - hanteerl die afwijkt van die van de zusterfaculteiten. Omdat de benadering van hel onderwijs anders was, ontstond binnen haar eerste faculteit te weten die der geneeskunde behoefte aan informatie over de kwaliteit van het onderwijs ter ondersteuning van curriculumontwikkeling. Daarnaast was het doel verantwoording af te leggen aan zusterfaculteiten en de overheid. Aanvankelijk richtte de aandacht zich voornamelijk op de eerste vier studiejaren, maar sedert 1987 ook op het viifde en zesde studiejaar. Gedurende deze twee laatste studiejaren lopen studenten stages binnen ziekenhuizen, huisartspraktijken en instellingen van de gezondheidszorg, de zogenaamde "co-assistentschappen". De problematiek die in dit proefschriff aan de orde wordt gesteld heeft betrekking op de ontwikkeling van een systeem voor kwaliteitszorg voor klinische co-assistentschappen in studiejaar 5 en 6 . De doelstellingen zijn als volgt gespecificeerd: de ontwikkeling van een instrument voor een valide en betrouwbare beoordeling van co-assistentschappen; het creëren van voorwaarden voor de invoering van dit instrument in de onderwijspraktijk;

het bevorderen van het gebruik van het instrument en het op grond van empirische gegevens doen van voorstellen om het onderwijs te verbeteren. 
Hoofdsfuk 2 beschrijft de historische ontwikkeling van het medisch onderwijs en geeft een overzicht van vernieuwingen. Betoogd wordt dat al enige honderden jaren kritische geluiden klinken over de inrichting van het medisch onderwijs. Na een periode van betrekkelijke stabiliteit na de Tweede Wereldoorlog wordt steeds duidelijker dat studenten onvoldoende toegerust zijn voor "de gezondheidszorg van de toekomst" en alleen al daarom de opleiding aanpassing verdient. Het huidige streven is om onderwijs te realiseren dat aansluit bij de behoeften van de maatschappij en uitgaat van een studentgerichte benadering. Deze geluiden ziin niet uniek voor Nederland, maar zijn ook elders te beluisteren. Internationaal zijn er initiatieven genomen om het onderwijs te vernieuwen. De oprichting van het Network of Community-Oriented Educational Institutions for the Health Sciences (1979) is hiervan een voorbeeld (Schmidt et al., 1991). Een toonaangevend rapport waarin ideeën over de richting van mogelijke veranderingen zijn verwoord, is het Report of the Panel of the General Professional Education of the Physician and College Preparation for Medicin (Association of American Medical Colleges; GPEP-rapport, 1984). De ideeën van het Network en het GPEP-report zijn in vele landen actueel en vormen basis voor de herziening van veel medische curricula. Ook in Nederland heeft zich dit gemanifesteerd in aanzetten tot nieuwe ontwikkelingen binnen het onderwijs zoals studentgericht onderwijs, "community-based" onderwijs, aandacht voor psycho-sociale aspecten naast medischetechnische aspecien, uitbreiding van het keuze-onderwijs en het aanbrengen van een onderwijskundig verantwoorde structuur in de opleiding.

Hoofdstuk 3 beschrijft de opbouw van het onderwijs in de geneeskunde. Hierbij is uitgegaan van het onderwijsprogramma aan de Faculteit der Geneeskunde van de Rijksuniversiteit Limburg. Ingegaan word op de basisfilosofie van de Medische Faculteit Maastricht. Vervolgens wordt de opzet van de eerste vier studiejaren beschreven. Omdat deze studie betrekking heeft op de stages in studiejaar 5 en 6 , is een uitvoerige beschrijving gegeven van de betreffende klinische stages.

Hoofdstuk 4 gaat in op de voorwaarden waaraan een organisatie moet voldoen om evaluatie van stageprogramma's mogelijk te maken. De invoering van een gesystematiseerde evaluatie stelt eisen aan de context. Deze context kan men enerzijds beschrijven aan de hand van het organisatieklimaat en anderzijds aan de hand van rolopvattingen van docenten. In de literatuur wordt een onderscheid gemaakt in rationalistische en natuurlijke organisatiemodellen (Dar- 
ling-Hammond \& Wise en Pease, 1983). Bij een rationalistisch model zijn regels en bevoegdheden op centraal niveau duidelijk vastgelegd en is de organisatie gekenmerkt door een planmatige opbouw van programma's. Bij een natuurlijk model ligt de verantwoordelijkheid voor het onderwijs bij de individuele docent en is er op centraal niveau slechts een beperkte regelgeving. Bovendien maken Darling-Hammond et al. (1983) een onderscheid in vier rolopvattingen van docenten: "teaching as labor", "teaching as craft", "teaching as art" en "teaching as profession". Het essentiële verschil tussen deze opvattingen is de mate waarin de docent autonoom kan handelen. Bii "teaching as labor" en "teaching as craft" is de autonomie van handelen vrijwel afwezig. Bij "teaching as profession" beschikt de docent over een zekere autonomie, maar binnen bepaalde grenzen. Bii "teaching as art" is de docent volledig autonoom in zijn handelen. Door de organisatie en rolopvattingen aan elkaar te relateren kan vastgesteld worden of de context geschikt is voor een systematische evaluatiebenadering. Een rationalistisch organisatiemodel zal samengaan met rolopvattingen waarbii docenten minder autonoom kunnen handelen, terwijl een natuurlijk organisatiemodel gekenmerkt wordt door rolopvattingen waarbij docenten meer autonomie hebben. Een modelmatige evaluatiebenadering ligt het meest voor de hand in een rationalistisch model, omdat zowel de organisatie, de inhoud als de vitvoering in detail omschreven en vastgelegd zijn.

Middels een analyse van het organisatieklimaat en de docentopvattingen die binnen de klinische stages van de Medische Faculteit Maastricht heersen werd geconstateerd dat er een duidelijke regelgeving is en taken en verantwoordelijkheden van docenten omschreven zijn. Hieruit volgt dat de situatie in Maastricht gekarakteriseerd kan worden als een rationalistische organisatie waarbij de raken en bevoegdheden van docenten omschreven zijn en de artsdocenten niet volledig autonoom kunnen handelen. Een modelmatige evaluatie van stages behoort dan ook tot de mogelijkheden.

Onderzoek naar de kwaliteit van onderwijs kan uitgaan van een procesgerichte of produktgerichte benadering. De operationalisering van het begrip kwaliteit verschilt al naar gelang het betrekking heeft op het onderwijsleerproces of de vitkomslen daarvan. Bij een procesgerichte benadering wordt de nadruk gelegd op de condities waaronder leren plaatsvindt. Bij een produktgerichte benadering concentreert men zich op het uiteindelijke resultaat van het leerproces. Evaluatie wordt in deze studie invulling gegeven vanuit een procesbenadering. Het belangrijkste argument hiervoor is dat vanuit een procesbenadering aanwijzingen verkregen worden over het "waarom" van de opbrengsten en daardoor specifieke informatie 
wordt verkregen over de richting van gewenste veranderingen. Vanuit deze invalshoek is een instrument geconstrueerd, waarbij kwaliteit gedefinieerd is als de voorwaarden, waaraan een stage naar onderwijskundige maatstaven moet voldoen.

In hoofdstuk 5 staat de constructie van het instrument centraal. De voorwaarden waaraan stages zouden moeten voldoen, zijn daartoe nader geconcretiseerd. Hierbij is gebruik gemaakt van studies, die zich richten op kenmerken van stages in het beroepsonderwijs en het medisch onderwijs. Een viteindelijke beschrijving van de voorwaarden heeft plaatsgevonden door hiervan een vertaling te maken naar de huidige co-assistentschappen. Dit resulteerde in 14 inhoudelijke domeinen die kenmerkend zijn voor kwaliteit. Het betreft de volgende domeinen:

1. de voorbereiding van de studenten op de stage inzake kennis en vaardigheden;

2. de informatie die studenten ontvangen over de inhoud en opzet van de stage in de vorm van een stageboek;

3. de persoonsgebonden begeleiding die studenten ontvangen met betrekking tot hun stagewerkzaamheden;

4. de begeleiding die de student ontvangt bij het medisch-technisch handelen;

5. de aandacht die tijdens de stage gegeven wordt aan zaken die niet patiëntgebonden zijn, maar betrekking heeft op alle aspecten die te maken hebben met de patiënt en context;

6. de kwaliteit van onderwijsactiviteiten, die speciaal voor studenten georganiseerd worden en inhoudelijk expliciet zijn afgestemd op de doelgroep;

7. het aanbod van patiëntproblemen met betrekking tot het aantal en het soort patiëntproblemen waarmee de studenten in aanraking komen;

8. de kwaliteit van patiëntgebonden leersituaties die plaatsvinden in een stage, zoals verblijf op de afdeling, het meelopen met afdelingsvisites, pathologie-besprekingen en röntgenbesprekingen;

9. de kwaliteit van de polikliniek wat betreft de beschikbare ruimle om zelfstandig patiënten te kunnen onderzoeken en de leerzaamheid;

10. de kwaliteit van studiefaciliteiten die beschikbaar zijn tijdens de stage, zoals ruimtelijke voorzieningen en leermiddelen;

11. de kwaliteit van stagebeoordeling die studenten aan het einde van een stageperiode ontvangen van de opleider; 
12. de gelegenheid tot zelfstudie die aan studenten gegeven wordt om naar aanleiding van praktijkervaringen zelfstudie te verrichten;

13. de tijdsbesteding tijdens de stage;

14. hel algemeen oordeel van de student over de stage ten aanzien van de sfeer, de organisatie en de leerzaamheid.

Deze domeinen zijn vervolgens geoperationaliseerd in ilems. Het viteindelijke meetinstrument kreeg de vorm van een vragenlijist, die studenten na afloop van elk stage dienen in te vullen. De vragenlijst is identiek voor alle stages en bestaat voor het grootste deel vit gesloten items die voorzien zijn van een vijfpunts- of Likertschaal. Voor elk item en voor elk domein wordt een gemiddelde score berekend. De domeinscores vormen de basis om beslissingen te nemen over aspecten van een stage die verandering behoeven.

Hoofdstuk 6 gaat nader in op de wijze waarop gegevens geïnterpreteerd worden. Personen die betrokken zijn bij de inrichting, uitvoering en controle van het klinisch onderwijs ontvangen een rapport, waarin de evaluatiegegevens met de bijbehorende interpretatie zijn opgenomen. Het is belangrijk dat deze rapportage helderheid geeft over datgene dat verandering behoeft in een stage en herkenbaar is voor de gebruikers. Daarom zijn voor de rapporlage twee vitgangspunten geformuleerd. Ten eerste wordt bij de rapportage uitgegaan van de onderscheiden domeinen. Dit zijn immers inhoudelijk clusters van vragen waarvan iedereen een duidelijke voorstelling heeft. Ten tweede wordt gerapporleerd op het niveau van de stage (bijvoorbeeld de stage interne geneeskunde) én het niveau van de stageplaats (bijvoorbeeld interne geneeskunde binnen het Academisch Ziekenhuis Maastricht).

Voor het geven van een betekenis aan de domeinscores wordt gebruik gemaakt van normen. Er kan een onderscheid gemaakt worden in drie typen normen: relatieve, absolute en zelfgerichte. Bij relatieve normen is de norm ontleend aan de scores van een referentiegroep. $\mathrm{Bij}$ absolute normen worden de scores vergeleken met een vooraf gedefinieerde standaard. Zelfgerichte normen, eveneens behorende tot de relatieve normen, worden ontleend aan voorafgaande metingen bij hetzelfde object. Elke type heeft zijn voor-en nadelen.

$\mathrm{Bij}$ de normen voor de stageevaluatie is getracht om zoveel mogelijk le profiteren van de voor-en nadelen van elk type. Dit heeft geresulteerd in het gebruik van gecombineerde normen. Relatieve normen zijn het vertrekpunt voor de inlerpretatie. Om ervoor te zorgen dat een bepaald minimumniveau gegarandeerd blifft, geldt naast een relatieve norm een absolute norm als ondergrens. Zelfge- 
richte normen, tenslotte, dienen om ontwikkelingen van een stage of stageplaats over een langere periode vast te stellen. Scores van opeenvolgende meermomenten worden hierbij vergeleken. De relatieve beoordeling vindt plaats op drie niveaus. Ten eerste worden stages onderling vergeleken. Hierdoor krijgt men per domein een algemene kwaliteitsindicatie. Ten tweede worden verschillende stageplaatsen binnen een en dezelfde discipline vergeleken. Hierdoor krijgt men specifieke informatie over de stageplaats. Ten derde wordt een sterkte-zwakte-analyse van een stageplaats gemaakt. De gemiddelde domeinscores van een stageplaats worden hierbii onderling vergeleken waarbij de stageplaats fungeert als haar eigen referentiekader. De beschreven voorbeelden illustreren het gebruik van normen in de praktiik.

Hoofdstuk 7 beschriift de realisatie van de stage-evaluatie in de praktijk. Het invoeren van een systematische evaluatie van alle stages met eenzelfde instrument kan als een vernieuwing beschouwd worden. Immers het evalueren van stages gebeurde nog niet systematisch en was sterk afhankelijk van het belang dat de individuele opleider hieraan hechtte. Studies naar het verloop van innovaties maken duidelijk dat een vernieuwing meer kans van slagen heeft als aan een aantal voorwaarden is voldaan (Dalin, 1978; Fullan \& Park, 1980). Binnen de instelling zijn daarom maatregelen getroffen. Er hebben gesprekken met stagecoördinatoren plaatsgevonden die er toe leidden dat iedereen in principe zijn volledige medewerking toezegde aan het doen slagen van de stage-evaluatie. Voorts zijn afspraken gemaakt over het verzamelen van gegevens, de wiize van rapportage en de verantwoordeliikheden van de betrokkenen. De instelling is erin geslaagd een klimaat te creëren waarin stage-evaluatie mogelijk is. De bruikbaarheid van evaluatiegegevens wordt geillustreerd aan de hand van praktijkstudie 1, 2 en 3.

Hoofdstuk 8 beschrifft twee studies naar de constructvaliditeit van het instrument. De constructvaliditeit verwijst naar de mate waarin de vragenlijst voor stage evaluatie de bedoelde eigenschap meet. Kwaliteit is in deze studie gedefinieerd in termen van voorwaarden waaraan een stageplaats moet voldoen. Deze voorwaarden zijn omschreven in 14 benoembare domeinen en vervolgens geoperationaliseerd in items. Het begrip kwaliteit is daardoor meetbaar gemaakt. Deze domeinen zijn zowel vanuit theoretisch als pragmatisch perspectief zinvol: theoretisch refereert naar de wijze waarop her begrip kwaliteit is geoperationaliseerd op basis van literatuurstudies en de inbreng van deskundigen; pragmatisch verwijst naar de praktische bruikbaarheid in die zin dal de domeinen dusdanig zijn 
gedefinieerd dat ze herkenbaar, relevant en manipuleerbaar zijn. Hieruit volgt dat er duidelijke verwachlingen geformuleerd kunnen worden over de structuur van de vragenlijst.

In studie 4 werd nagegaan in hoeverre deze op inhoudelijk en pragmatisch gespecificeerde structuur ook op empirische gronden te rechtvaardigen is. Hierbij is gebruik gemaakt van toetsende factoranalyse (LISREL), die is vitgevoerd op de data die in $1989 \mathrm{bii}$ alle stages verzameld zijn $(N=875)$. In de analyse zijn 11 van de 14 domeinen betrokken. Drie domeinen werden niet meegenomen, daar de hiertoe behorende items open vragen waren en/of bepaalde scores ontbraken. Naast de in de praktijk gehanteerde indeling in domeinen, zijn vijf alternatieve indelingen getoetst. Voor elk model zijn de volgende indices berekend: $\mathrm{CHI}$-kwadraat waarde, de grootte van de residuen (RMSR), de Goodness-of-Fit Index (GFI), de adjusted Goodness-of-Fit Index (AGFI) en de rho-waarde. Op basis hiervan is vastgesteld welke indeling op empirische gronden het beste te rechtvaardigen is. De resultaten wijzen uit dat de overeenstemming tussen het beoogde model en de data redelijk is en zeker in vergelijking met alternatieve modellen zeer acceptabel is. Besloten is om het model in voorgestelde vorm te handhaven, mede gezien de duidelijke rationale die aan het instrument ten grondslag ligt en de bruikbaarheid.

In studie 5 is onderzocht of de structuur van de vragenlijst over opeenvolgende jaren constant is. Daartoe is de invariantie tussen de correlatiematrices van de domeinen met betrekking tot 1989 $(N=875)$ en 1990 ( $N=851)$ onderzocht. Geconcludeerd kan worden dat de correlaties tussen de domeinen van de vragenlijst stabiel zijn over een bepaalde periode (in dit geval twee jaar). De resultaten van beide studies vormen een duideliike indicatie voor een redelijk goede constructvaliditeit.

Hoofdstuk 9 doet verslag van de betrouwbaarheid van het instrument. Om hierover uitspraken te doen zijn generaliseerbaarheidsstudies uitgevoerd. Het doel hiervan is tweeledig. Ten eerste om een indicatie te krijgen van de betrouwbaarheid en daarmee indirect van de accuraatheid van de scores én van de beslissingen die genomen worden op basis van de metingen met het instrument. Ten tweede om vast te stellen hoeveel waarnemingen van studenten nodig zijn om tenminste een betrouwbaar oordeel te kunnen geven door het aantal studenten te variëren. De opzet en vitvoering van de studies is athankelijk van datgene warnaar gegeneraliseerd wordt, dus van het gebruiksdoel. Zoals in hoofdstuk 6 werd betoogd, kent het instrument drie gebruiksdoelen. Hieruit volgt dat drie generaliseerbaarheidsstudies zijn uitgevoerd, respectievelijk gericht op het 
doen van vitspraken op niveau van de stage (studie 6), op het niveau van de stages in ziekenhuizen (studie 7) en op het niveau van de stageplaatsen, uitgaande van een sterkte-zwakte-analyse (studie 8). De beantwoording van de betrouwbaarheidsvragen heeft plaatsgevonden vanuit een relatiefgeoriënteerd en beslissingsgericht perspectief. Bij een relatief georiënteerd perspectief worden - afhankelijk van het object van meting - stages, stageplaatsen of domeinen onderling vergeleken. De betrouwbaarheid wordt dan uitgedrukt in een generaliseerbaarheidscofficiënt (G-coëfficiënt). Bij een beslissingsgericht perspectief wordt uitgegaan van een absoluut criterium (onder grensscore). De betrouwbaarheid wordt dan uitgedrukt een adjusted-phi-coëfficiënt. Bovendien is de standaardmeetfout berekend. De berekeningen zijn uitgevoerd met het programma GENOVA (Crick \& Brennan, 1983). Belangriike informatie ten aanzien van de onderzoeksdesigns is dat studenten en items als random variabelen opgevat worden en studenten genest zijn binnen co-assistentschappen en gekruist met de items.

Uit de resultaten van studie 6 en 7 blijkt dat de G-coëfficiënten over het algemeen, ongeacht het aantal waarnemingen, aan dé lage kant zijn. Hieruit volgt dat rangording van stages en stageplaałsen naar één schaalwaarde verschil niet mogelijk is. De standaardmeeffouten zijn daarentegen zeer acceptabel, wat een indicatie is voor de nauwkeurigheid waarmee gemeten wordt. De adjusted-phi-coëfficiënten zijn reeds bij een gering aantal waarnemingen, 25 waarnemingen per stage en 5 waarnemingen per stageplaats, zeer bevredigend. Uit de resultaten van studie 8 blijkt dat de G-coëfficinten reeds bij 10 waarnemingen zeer acceptabel zijn, evenals de standaardmeetfouten. Hieruit volgt dat bij het maken van een sterkle-zwakle-analyse de domeinen naar één schaalwaarde verschil betrouwbaar geordend kunnen worden.

Op basis van de uitkomsten van deze studies kan geconcludeerd dat het mogelijk is om met dit instrument betrouwbare uitspraken te doen op alle niveaus van interpretatie. Hieruit volgt dat de beslissingen die tot nu genomen zijn op basis van de verzamelde evaluatiegegevens verantwoord zijn. Voorts kan uit de resultaten afgeleid worden dat het niet noodzakeliik is dat alle studenten na afloop van elke stage de vragenlijst invullen. In de toekomst behoort een efficiëntere opzet van de dataverzameling tot de mogelijkheden, waarbij een aantal van 10 a-selecte studentwaarnemingen per stageplaats toereikend is voor een betrouwbare evaluatie.

In hoofdstuk 10 volgt de discussie en een overzicht van de belang. rijkste conclusies. Ingegaan wordt op de setting waarbinnen medisch onderwijs plaatsvindt en de consequenties hiervan voor 
stage-evaluatie, de operationalisering van het begrip kwaliteit, het belang om alle relevante partijen te betrekken bij de stage-evaluatie, de mogelijkheden om te evalueren in een minder gestructureerde onderwijsomgeving, het achterwege blijven van directe effeclen bij stage-evaluatie en het belang van een verdere professionalisering van arts-begeleiders. Op basis van de resultaten van het hier gepresenteerde onderzoek lijkt het gerechtvaardigd om te stellen dat evaluatie van klinisch onderwijs mogelijk is en bovendien dat een dergelijke benadering in de geneeskunde bruikbare informatie biedt om de kwaliteil van stages te bewaken en te bevorderen. 


\section{SUMMARY*}

The aim of this dissertation is to describe the development of a system for quality care in clinical education, i.e. the clinical clerkships in hospitals. Chapter 1 provides a framework for this study and a (research) problem is defined. The increasing interest for quality of education in universities is highlighted. This interest is reflected and was stimulated by a number of policy measures initiated by the Dutch Ministry of Education (HOAK, 1985; HOOP, 1987) requiring universities to explicitly account for their educational quality. To provide for the necessary information evaluation systems were needed. Prior to the national interest, the University of Limburg had worked on the development of a system for quality control in education. The junior status of the university (founded in 1974) and the adoption of an innovative learning approach (problem-based learning) motivated the medical school to develop an evaluation system for quality of education. Originally the evaluation system focused on the preclinical years (year one through four), but after 1987 the attention also shifted to the clinical years (years five and six). In the clinical years students rotate through a number of clerkships in hospitals, family practices, and other institutions of health care. This dissertation addresses the development of such an evaluation system to assess quality of education in the clinical clerkships of year five and six. More specifically, the objectives are:

- to develop a reliable and valid instrument to assess the quality of education in clerkships;

to establish the enabling conditions to introduce such a sys-

tem;

to promote the use of this instrument and to propose improvements in education based upon empirical data.

In a more broader perspective, chapter 2 describes historical developments of medical education in The Netherlands. It is argued that medical education has been criticized for its structure and content for centuries. After Wold War II, following a relatively stable period in medical education, it becomes increasingly apparent that students are insufficiently prepared for modern health care. Education today is therefore progressively characterized by adapting to the needs of sociely in combination with a student centered approach. These developments are not unique for The Netherlands. The foundation of a Network of Community-Oriented Educational Institutions for the Health Sciences (Schmidt et al., 1991) is an appropriate illustration of this. Similarly, the publication of the Report of the Panel of the

* Met dank aan Cees van der Vleuten en Jeannet Kalk. 
General Professional Education of the Physician and College Preparation for Medicine (Association of American Medical Colleges; GPEP-report, 1984), declaring views on the requirements of the physician in the twenty-first century, became an authorative document. Both the Network and the GPEP-report have stimulated innovations in medical curricula. In The Netherlands they have inspired developments such as student-centered education, community-based education, more attention for psycho-social aspects of disease, expansion of electives in education, and the establishment of an educationally founded structure in educational programs.

Chapter 3 describes the structure of training programs in medicine in The Netherlands, using the Maastricht medical school as a frame of reference. The basic philosophy of the medical school is discussed. Subsequently, the program of the first four years are described. Given the aim of this dissertation, the program of year five and six are more elaborately discussed, including a description of the separate clinical clerkships.

Chapter 4 addresses the organizational requirements of evaluation of clinical clerkships. The introduction of a systematic evaluation system sets specific demands to the educational context. The context can be described by the organizational climate on the one hand and by the teaching conceptions of faculty on the other hand. The literature distinguishes between rationalistic and naturalistic organizational models (Darling-Hammond, Wise \& Pease, 1983). In a rationalistic model the rules and authorities are centrally defined. The organization is characterized by a coordinated structure and sequence of educational programs. In a naturalistic model individual teachers carry responsibility with limited central regulation. In relation to the leaching role Darling-Hammond et al. (1983) distinguish four conceptions, each varying in the degree of autonomy on the part of the teacher. In "leaching as labor" and "teaching as craft" hardly any autonomy exists, in "teaching as profession" the teacher has restricted autonomy within certain limits, whereas in "teaching as art" the teacher has more autonomy. Whether a systematic evaluation is achievable can be assessed by marching the organizational characteristics and the teaching conceptions. A rationalistic organization model is more likely associaled with less autonomous teaching conceptions and with more central regulation. A systematic approach to evaluation is best conceivable in a rationalistic model of organization.

An analysis of the organizational climate in the clinical program and the teaching conceptions of clinical teachers involved 
indicated to clear central regulations in which the tasks and authority of teachers were well defined. It was concluded that a systematic evaluation approach was potentially achievable.

The assessment of educational quality can be based on a process or oulcome oriented approach. The operationalization of the concept of quality will vary depending whether the focus is on the learning process or on the outcomes of that process. In a process oriented approach the conditions of learning are emphasized. In an outcome oriented approach the final outcome of that process is essential. In this study a process oriented strategy is adopted. The main motivation for this choice is that a process oriented approach provides insight into the causes of possible outcomes and therefore allows the derivation of specific information related desirable educational changes. From this perspective, an instrument has been developed in which quality is defined as a set of educational conditions to which a clerkship has to meet.

Chapter 5 entirely focusses on the construction of the instrument. The educational conditions to be met by the clerkships are further delineated by using studies aiming characterizing clerkships and apprenticeships in vocational training and medical education. A final definition of requisite educational conditions was established by transforming the generic literature findings to the situation of the clinical clerkships. This yielded fourteen different domains reflecting quality of education. These are:

1. preparation of students with regard to knowledge and skills;

2. received student information on content and structure of the clerkship in a formal clerkship manual;

3. personal supervision in general;

4. supervision especially of rechnical skill performance;

5. attention to non-patient related affairs (context of patient situation);

6. quality of educational activities directly organized for student learning;

7. patient mix in terms of problem variation and frequency;

8. quality of patient related learning situations, such as ward attendance, participation in patient rounds, pathology radiography seminars;

9. quality of the outpatients' clinic regarding available office facilities to independently examine patients;

10. quality of learning facilities available such as office facilities and learning resources;

11. quality of the clinical competence assessment give to student at the end of the clerkship; 
12. opportunity for self-study as a result of patient contacts;

13. spread of activities over time;

14. general student assessment of the clerkships quality in relation to armosphere, organization and instructiveness.

These domains are subsequently operationalized into items.

The final instrument was a uniform questionnaire which was administered at the end of all clerkships. The majority of items are in a fivepoint Likert type scale and a limited number required a write-in response from the students. For every item a mean score is calculaled across all sludent responses which are subsequently aggregated to domain scores. The domain scores are used to take decisions for improving the quality of clerkships.

Chapter 6 describes the way in which the evaluation data are interpreted. The people involved in design, realization and supervision of clinical education receive a report containing the evaluation data and their interpretation. Quite important is that the report clarifies possible suggestions for improvement amenable for change and recognizable for the target group(s). To achieve this clarity two principles are formulated. Firstly, the feedback is based upon the various dimensions, because they represent clusters of items reflecting intuitively clear conceptions of quality. Secondly, feedback is tuned to the specific clerkship (e.g. internal medicine) within location (e.g. internal medicine academic hospital Maastricht).

To interpret the domain scores standards are utilized. Three types of standards are generally employed: relative, absolute and self-directed standards. Relative standards are derived from scores of a reference group. The absolute standards are obtained by definition, usually based upon content or expertise, of required performance or scores. Self-directed standards, also a special kind of relative standards, are derived from previous measurements on the same object. Each type has its (dis)advantages, which has often resulted in combined or compromise standards. Relative standards are used in conjunction with absolute standards, the latter to guarantee a minimum requirement beyond which no compromises are made. Finally, self-directed standards are used to monitor longitudinal developments in clerkships over time.

The relative interpretation of scores here is conducted by using three different reference groups: 1] within the clerkship across domains, 2) other clerkships across all disciplines, 2) other clerkships within the same discipline. The first reference yields a profile of quality strengths and weaknesses within a clerkship, the latter two provide comparative information in relation to other clerkships. A number of practical illustrations are given in this chapter. 
In chapter 7 the practical implementation of the evaluation system is outlined. The implementation of a systematic evaluation across all clerkships can be considered as a significant innovation in the educational program, since in the existing situation evaluation occurred unsystematically and depended largely on the interest of the individual teacher. Studies of innovations indicate that success is associated with the fulfillment of a number of conditions (Dalin, 1978; Fullan \& Park, 1980]. A number of activities to create these conditions were therefore organized. To ensure full cooperation of the clerkship supervisors special briefing meetings were organized. Agreements were made on collection of data, ways of reporting these data and the responsibilities of those involved herein. This stimulated a climate in which clerkship evaluation became a fact. The chapter subsequently illustrates the usefulness of evaluation findings in three studies in practice (studies 1, 2, and 3).

Chapter 8 describes two studies on the construct validation of the instrument. Construct validity here refers to the extent to which the questionnaire reflects the concept intended to be measured. By defining quality in terms of required educational conditions in fourteen different quality domains, each operationalized into sets of items reflecting that dimension, quality has become measurable. The quality domains are both theoretically relevant and practically useful. Theoretically because the domains are founded in literature and expert judgement, and pragmatically because the domains are intuitive, relevant and amenable for manipulation. Hence, clear expectations can be hypothesized on the struclure of the questionnaire.

In study 4 the theoretical and pragmatic domains were tested on empirical evidence through confirmatory factor analysis (LISREL) on the 1989 data from all clerkships $(N=875)$. Three domains were discarded from analysis because of the use of write-in questions and/or problems with missing data. In addition to the hypothesized domain division, five alternative domain models were tested. A multitude of slatistical indices were used to judge the goodness-of-fit of the various models to the empirical data structure. The results indicated that the hypothesized model showed a reasonable fit and compared to the alternative models appeared best. It was concluded to mainlain the suggested model.

In study 5 the reproducibility of the factor structure was invesfigated. The domain correlation matrices were tested on invariance across the $1989(\mathrm{~N}=875)$ and $1990(\mathrm{~N}=851)$ data. The results showed a stable factor structure. Both studies therefore indicated to a positive construct validity of the instrument. 
Chapter 9 investigates the reliability of the evaluation instrument by using generalizability theory. The aim was twofold. First, the aim was to obtain an estimate of the reliability, i.e. the accuracy of derived scores and of decisions taken with the instrument. Second, to assess the number of observations required to achieve sufficiently reliable scores. Various generalizability studies were undertaken following the three perspectives on decision-making that were described in chapter 6 . These were studies to asses the reliability of scores for: 1) comparing clerkship quality in relation to other clerkships within the same discipline and hospital (study 6); 2) comparing clerkship quality in relation to other hospitals (study 7); 3 ) comparing the quality profile within a clerkship on the various domains (study 8). The interpretation of scores was both norm-referenced and mastery referenced. In a norm-referenced score interpretation scores are relatively compared across clerkships, hospitals or profiles, i.e. in relation to each other. Reliability is expressed in a generalizability coefficient (G-coefficients). In a mastery referenced perspective scores are interpreted in relation to a particular cut-off score (minimum quality) and, in stead of a score reliability, a decision reliability is estimated. Reliability is expressed in a adjusted phi-coefficient. In addition, the (norm-referenced) standard error of estimate was estimated. The results of study $\sigma$ and 7 indicated to fairly low G-coefficients, irrespective of the number of observations, due to rela-tively small clerkship variation. The standard errors of measurement, indicating to the amount of noise in the measurement, were on the other hand quite acceptable, allowing significant interpretation of a single scale value. This was achieved with approximately 25 observations for clerkships and 10 observations for hospitals. The adjusted phi-coefficients were all satisfying, even with small numbers of observations (25 for clerkships and 5 for hospitals). Siudy 8 yielded acceptable G-coefficients and standard errors of measurement starting even at 10 observations. The general conclusion was that the instrument allows for reliable inferences at all levels of interpretation and that the assembled evaluation data in this thesis are sufficiently reproducible. It was also concluded that more efficient data-gathering is plausible by restricting the number of observations to approximately ten randomly completed student questionnaires per clerkship.

Chapter 10 reviews the most important conclusions of this dissertation. It discusses the organizational context of medical education and its consequences for clerkship evaluation, the definition and operationalization of the quality concept, the importance of involving all parties in the evaluation, the possibilities of evaluation in less 
structured situations, lack of immediate effects of evaluation, and the importance of professional development and training of clinical supervisors. The results of this thesis warrants the conclusion that clerkship evaluation is feasible and useful to improve and maintain the educational quality of clerkships. 


\section{OVERZICHT BIJLAGEN}

Overzicht van domeinen

$1 \quad$ Vragenlijst praktisch medisch onderwijs

2 Correlatiematrices (studie 5)

3 Overzicht van het aantal studenten dat gebruikt is voor betrouwbaarheidsstudie (hoofdstuk 9, sludie 6)

$4 \quad$ Overzicht van de gemiddelde score en standaarddeviaties onderscheiden naar stage (hoofdstuk 9, studie 6)

5 Overzicht van het aantal ziekenhuizen en studenten dat gebruikt is voor betrouwbaarheidsstudie (hoofdstuk 9, studie 7$)$

6 Overzicht van de gemiddelde score en standaarddeviaties onderscheiden naar domein en stageplaats (hoofdstuk 9, studie 71

7 Overzicht van het aantal studenten dat gebruikt is voor betrouwbaarheidsstudie (hoofdstuk 9, studie 8) 


\section{OVERZICHT VAN DOMEINEN}

1. Voorbereiding op de stage

2. Stageboek

3. Persoonsgebonden begeleiding

4. Begeleiding medisch-technisch

5. Aandacht patiënt en context

6. (Onderwijsactiviteiten]

7. Aanbod patiëntproblemen

8. Patiëntgebonden leersituaties

9. Polikliniek

10. Studiefaciliteiten

11. Stagebeoordeling

12. (Zelfstudie)

13. Algemeen oordeel

14. (Tijdsbesteding)

(1) niet meegenomen in de analyses van hoofdsluk 8 (validiteit) en hoofdstuk 9 (betrouwbarheid) 


\section{BIJLAGE 1}

Aan: Co-assistenten jaar 5 en 6

Van: Ineke Wolfhagen

Betreft: Programmaevaluatie PMOK -

Beste co-assistent,

de faculteit der geneeskunde tracht verschillende gegevens te verzamelen over de gang van zaken in de klinische stages. Een zeer belangrijk gegeven hierbij is het oordeel dat studenten hebben over de gevolgde stage(s). Daarom zouden wij je willen verzoeken bijgaand evaluatieformulier in te vullen. De resultaten zullen worden gerapporteerd aan alle bij het klinisch onderwijs betrokkenen. Rapportage gebeurt op anonieme basis.

Het merendeel van de vragen bestaat uit beweringen, waarop je kunt reageren door omcirkeling van een cijfer.

$1=$ = "volledig oneens" mel de bewering

2 = "tamelijk oneens"

$3=$ "neutraal"

$4=$ "tamelijk eens"

$5=$ "volledig eens".

Indien je de vraag niet van toepassing acht, zet je een streep door het betreffende vraagnummer. Aan het eind van de vragenlijst vind je enkele open vragen.

We hopen op je medewerking.

Ineke Wolfhagen,

Project Programma-Evaluatie, vakgroep O. \& O., Faculteit der Geneeskunde Universiteitssingel 50

N.B.: dit is een algemene vragenlijst. De specifieke vragen per slage zijn hierin niet opgenomen. 
Naam:

Registratienummer:

Deze pagina wordt voor verwerking van de gegevens verwijderd.

Daar we een optimale respons willen hebben, willen we verzoeken om je naam te noteren. We kunnen dan controleren of iedereen het formulier heeft geretourneerd. Alle gegevens worden vertrouwelijk verwerkt en geanonimiseerd gepubliceerd. 


\section{Programma-evaluatie Praktisch Medisch Onderwijs}

De hierna volgende vragen hebben betrekking op de zojuist beëindigde stage.

1. Voltooide stages (aankruisen wat van toepassing is):

0 1. $\mathrm{PMOH}$

0 2. Interne Geneeskunde

0 3. Chirurgie

0 4. Gynaecologie/Verloskunde

0 5. Paediatrie

0 6. Neurologie

0 7. Oogheelkunde

0 8. KNO

0 9. Dermatologie

0 10. PMO-PMS

2. Deze vragenlijst heeft betrekking op de stage

3. Huidige stageplaats (aankruisen wat van toepassing is):
0 1. Maastricht
$0 \quad 5$ = Eindhoven
0 2. Heerlen
$0 \quad 6=$ Brunssum
0 3. Sittard
$0 \quad 7=$ Venlo
0 4. Roermond

4. Datum eind stage:

Voorbeeld:

dag mnd. jr.

dag mnd. ir.

03

1191
......
......

5. Datum waarop vragenlijst is ingevuld:

dag mnd. jr.

I Voorbereiding op stage

volledig

volledig

oneens eens

6. Over het geheel genomen was $i k$ op de benodigde vaardigheden voldoende voorbereid.

$\begin{array}{lllll}1 & 2 & 3 & 4 & 5\end{array}$

7. Over het geheel genomen was ik qua theoretische kennis voldoende voorbereid.

$\begin{array}{lllll}1 & 2 & 3 & 4 & 5\end{array}$ 


\section{Informatie over stage}

8. Uit het stageboek werd duidelijk welke kennis en vaardigheden aan het begin van de stage verwacht werden.

$\begin{array}{llll}2 & 3 & 4 & 5\end{array}$

9. Het stageboek gaf een duidelijk overzicht van de patiënlproblemen die van belang waren.

$\begin{array}{lllll}1 & 2 & 3 & 4 & 5\end{array}$

10. Uit het stageboek werd duidelijk op welke wijze de rol van co-assistent ingevuld zou worden (welke mate van verantwoordelijkheid, werkzaamheden etc.).

11. Het stageboek verschafte duidelijke informatie over de kennis en vaardig. heden, attitude en medisch denken en handelen die aan het einde van de stage verwacht werden.

12. Het stageboek verschafte een duidelijk overzicht over de wijze van beoordeling.

\section{Persoonsgebonden begeleiding}

13. Ik werd voldoende geïntroduceerd in de stageplaats.

$\begin{array}{lllll}1 & 2 & 3 & 4 & 5\end{array}$

14. Ik had een duidelijk takenpakket. $\quad \begin{array}{llllll}1 & 2 & 3 & 4 & 5\end{array}$

15. Het was mij duidelijk wie mijn begeleider(s) was (waren).

16. De begeleider(s) was (waren) op de hoogte van de uitgangspunten van het Maastrichise onderwijssysteem. $1 \begin{array}{llllll}1 & 2 & 3 & 4 & 5\end{array}$

17. De begeleider(s) was (waren) op de hoogte van de stagedoelen.

12345


18. Ik vond de begeleiding van voldoende kwaliteit.

19. Ik ben tevreden over frequentie en duur van de begeleiding.

\section{Begeleiding bii medisch-technisch handelen}

20. De begeleider(s) demonstreerde(n)

mij in voldoende mate een aantal

vaardigheden met de bedoeling om

mijn vaardigheden te optimali-

seren.

$\begin{array}{lllll}1 & 2 & 3 & 4 & 5\end{array}$

21. Ik kreeg nuttige adviezen m.b.t.

mijn functioneren.

12345

De doelen van deze stage in aanmerking genomen, werd door de begeleiders voldoende aandacht besteed aan:

22. Anamnese, lichamelijk onderzoek, interpretatie van gegevens, d.d., therapie en aanvullend onderzoek. $\quad \begin{array}{llllll}1 & 2 & 3 & 4 & 5\end{array}$

23. Verslaglegging. $1 \begin{array}{lllll}2 & 3 & 4 & 5\end{array}$

24. Fysisch diagnostische vaardigheden. $1 \quad 2 \quad 3 \quad 4 \quad 4 \quad 5$

25. Therapeutische varardigheden. $\quad \begin{array}{llllll}1 & 2 & 3 & 4 & 5\end{array}$

\section{Aandacht voor patiënt en context}

De doelen van deze stage in aanmerking genomen, werd door de begeleiders voldoende aandacht besteed aan:

26. Voorlichting aan patiënten.

$\begin{array}{lllll}1 & 2 & 3 & 4 & 5\end{array}$

27. Vervolgen resp. begeleiden van de patiënt.

$12 \quad 3 \quad 4 \quad 5$

28. Gesprekstechnische vaardigheden. $1420 \begin{array}{llll} & 2 & 4 & 5\end{array}$ 
29. Mijn omgang met patiënten.

$\begin{array}{lllll}1 & 2 & 3 & 4 & 5\end{array}$

30. Een integrale benadering van somatische en psychische aspecten.

$\begin{array}{lllll}1 & 2 & 3 & 4 & 5\end{array}$

31. Emoties die bij mij opgeroepen werden.

32. Organisatie gezondheidszorg. $\quad \begin{array}{llllll}1 & 2 & 3 & 4 & 5\end{array}$

33. Kostenaspect van de gezondheidszorg.

34. Samenwerken le en 2 e lijn.

35. Multidisciplinaire benadering van patiëntproblemen.

36. Medischelhische aspecten.

37. De samenwerking tussen artsen en verpleegkundigen.

\section{Kwaliteit onderwijsactiviteiten}

38. Het aantal specifiek voor het onderwijs in groepsverband georganiseerde bijeenkomsten (praatjes e.d.) was voldoende.

39. Deze bijeenkomsten vond ik leerzaam.

\section{Aanbod patiëntproblemen}

40. Het patiëntenaanbod was voldoende gevarieerd.

41. a. Het aantal patiëntproblemen waarmee ik geconfronteerd ben, was voldoende. 
b. Hoeveel patiënten heb je gemiddeld per week min of meer volledig bekeken (de $0 \quad 1-5$ anamnese afgenomen, onder- $0 \quad 6-10$ zoek verricht en evaluatie- $0 \quad 11-15$ plan opgesteld)? (S.v.p. aan- 0 16-20 kruisen wat van toepassing is]. 0 meer dan 20 per week

\section{Kwaliteit patiëntgebonden leersituaties}

$\begin{array}{lr}\text { niet } & \text { zeer } \\ \text { leerzaam } & \text { leerzaam }\end{array}$

42. Het meelopen van afdelingsvisites was:

$\begin{array}{lllll}1 & 2 & 3 & 4 & 5\end{array}$

43. De patiëntbesprekingen waren:

$\begin{array}{lllll}1 & 2 & 3 & 4 & 5\end{array}$

\section{Kwaliteit polikliniek}

44. Het verblijf op de poli was:

\begin{tabular}{lllll}
1 & 2 & 3 & 4 & 5 \\
volledig & & & volledig \\
oneens & & \multicolumn{2}{r}{ eens }
\end{tabular}

45. Er was op de poli een ruimte om zelfstandig een patiënt te kunnen onderzoeken.

$\begin{array}{lllll}1 & 2 & 3 & 4 & 5\end{array}$

\section{Kwaliteit studiefaciliteiten}

46. Er was een geschikte plaats om te studeren beschikbaar.

$\begin{array}{lllll}1 & 2 & 3 & 4 & 5\end{array}$

47. Als ik er behoefte aan had kon ik van de beschikbare leermiddelen gebruik maken.

48. De leermiddelen waren inhoudelijk van voldoende kwaliteit.

$\begin{array}{lllll}1 & 2 & 3 & 4 & 5\end{array}$

\section{Kwaliteit stagebeoordeling}

49. De stagebeoordeling vond plaats op het afgesproken tijdstip.

$\begin{array}{lllll}1 & 2 & 3 & 4 & 5\end{array}$




$$
\begin{array}{lr}
\text { volledig } & \text { volledig } \\
\text { oneens } & \text { eens }
\end{array}
$$

50. De wijze van stagebeoordeling vond plaats zoals afgesproken.

$\begin{array}{lllll}1 & 2 & 3 & 4 & 5\end{array}$

51. Het is mij duidelijk op grond van welke informatie ik beoordeeld ben. $\begin{array}{lllll}1 & 2 & 3 & 4 & 5\end{array}$

\section{Gelegenheid tot zelfstudie}

52. De stage liet voldoende ruimte voor zelfstudie.

\section{Algemeen oordeel}

53. Geef een schoolcijfer (van $1 \mathrm{t} / \mathrm{m}$ 10) voor de volgende aspecten m.b.t. deze stage in zijn totaliteit:

\section{Tijdsbesteding tijdens de stage}

54. Het aantal uren dat ik gemiddeld per week in het ziekenhuis aanwezig was (inclusief diensten) bedroeg: uren per week

55. Buiten de slagewerktijd (b.v. 's avonds en in het weekend) studeerde ik nog gemiddeld:

56. Hoeveel uren per week werden gemiddeld besteed aan nietleerzame activiteiten? uren per week

\section{Open vragen}

57. Wat vond je erg goed in de stage? 
58. Wat zou er veranderd moeten worden in de stage?

59. Eventuele suggesties voor studenten die deze stage nog moeten volgen (voorbereiding/activiteiten tijdens stage):

Bedankt voor je medewerking. 


\section{BIJLAGE 2}

\section{A. Correlatie-coëfficiënten ruwe scores 1989 ( $N=875)$}

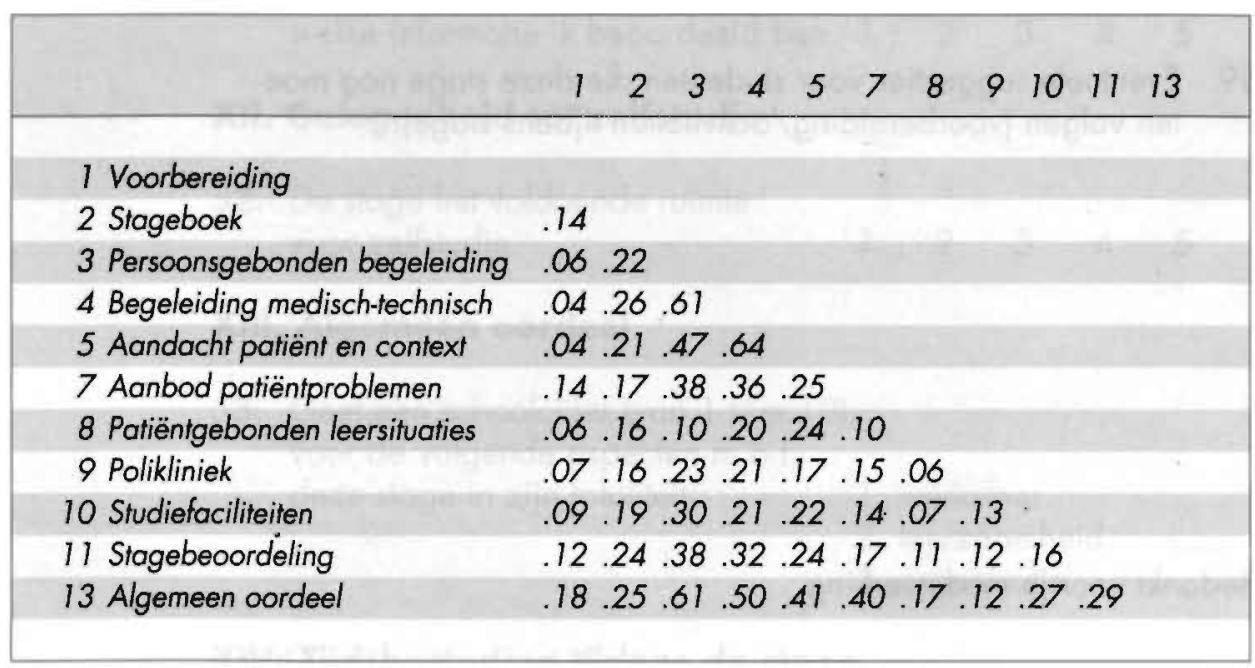

\section{B. Correlatie-coëfficiënten ruwe scores 1990 ( $N=851$ )}

\begin{tabular}{|c|c|c|c|c|c|c|c|c|c|c|}
\hline & 12 & 3 & 4 & 5 & 7 & 8 & 91 & & & 13 \\
\hline \multicolumn{11}{|l|}{1 Voorbereiding } \\
\hline 2 Stageboek & .13 & & & & & & & & & \\
\hline 3 Persoonsgebonden begeleiding & .18 .40 & & & & & & & & & \\
\hline 4 Begeleiding medisch-technisch & .17 .33 & 55 & & & & & & & & \\
\hline 5 Aandacht patiënt en context & .19 .31 & 43. & 66 & & & & & & & \\
\hline 7 Aanbod patiëntproblemen & .16 .18 . & 32 . & 31. & 31 & & & & & & \\
\hline 8 Patièntgebonden leersituaties & .12 .15 & 23. & 42 . & & 20 & & & & & \\
\hline Q Polikliniek & .16 .23$. & 21. & 16. & 13. & 17 & 02 & & & & \\
\hline 10 Studiefaciliteiten & .15 .17 & 25 . & 22 . & 13. & 03 & 10 & 12 & & & \\
\hline 11 Stagebeoordeling & .13 .25 . & 35 . & 30 . & 22 . & 22 & 06 & 21.2 & & & \\
\hline 13 Algemeen oordeel & .09 .28 & 53. & 45 . & 37. & 38 & 29 & 13.1 & & & \\
\hline
\end{tabular}




\section{BIJLAGE 3}

Overzicht van het aantal studenten dat gebruikt is voor betrouwbaarheidsstudie (hoofdstuk 9, studie 6)

\begin{tabular}{|lll|}
\hline $\begin{array}{l}\text { Naam } \\
\text { domein }\end{array}$ & $\begin{array}{l}\text { aantal } \\
\text { stages }\end{array}$ & $\begin{array}{l}\text { aantal studenten } \\
\text { per stage }\end{array}$ \\
\hline 1 Voorbereiding op de stage & 8 & \\
\hline 2 Stageboek & 8 & 253 \\
3 Persoonsgebonden begeleiding & 8 & 79 \\
\hline Begeleiding medisch-technisch & 8 & 128 \\
\hline 5 Aandacht patiënt en context & 8 & 238 \\
\hline Aanbod patiëntproblemen & 8 & 247 \\
8 Patiëntgebonden leersituaties & 8 & 236 \\
\hline Polikliniek & 8 & 248 \\
10 Faciliteiten & 8 & 241 \\
\hline 17 Stagebeoordeling & 8 & 238 \\
\hline Algemeen oordeel & 8 & 251 \\
\hline
\end{tabular}




\section{BIJLAGE 4}

\section{Overzicht van de gemiddelde scores en standaarddevia- ties onderscheiden naar stage (hoofdstuk 9, studie 6)}

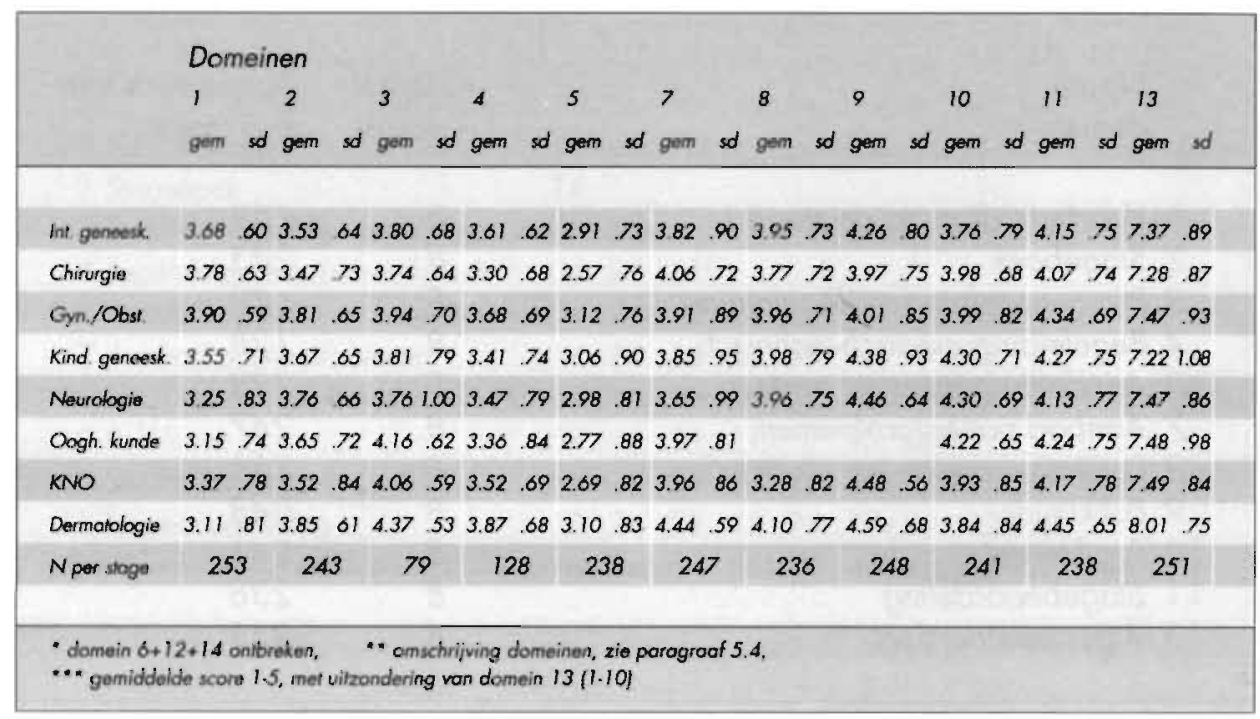




\section{BIJLAGE 5}

Overzicht van het aantal ziekenhuizen en studenten dat gebruikt is voor betrouwbaarheidsstudie (hoofdstuk 9, studie 7)

\begin{tabular}{|c|c|c|c|c|c|c|c|c|c|c|c|c|c|c|c|c|}
\hline & \multicolumn{2}{|c|}{ Domeinen } & \multirow{2}{*}{\multicolumn{2}{|c|}{3}} & \multirow[b]{2}{*}{4} & \multirow{2}{*}{\multicolumn{2}{|c|}{5}} & \multirow[b]{2}{*}{7} & \multirow[b]{2}{*}{8} & \multirow{2}{*}{\multicolumn{2}{|c|}{9}} & \multirow[b]{2}{*}{10} & & \multirow{2}{*}{\multicolumn{2}{|c|}{13}} \\
\hline & 1 & 2 & & & & & & & & & & & & 11 & & \\
\hline & $2 \hbar N$ & $V$ zh $N$ & $N$ zh & $N$ & $z h N$ & $N z h$ & $N$ & zh $N$ & $\sqrt{ } z h \Lambda$ & $N z h$ & $\operatorname{zh} N$ & ah & $N z$ & $z h N$ & $\sqrt{ } z h$ & 1 \\
\hline I Interne geneeskunde & 425 & 5425 & 542 & 25 & 424 & & 24 & 425 & 542 & 244 & 425 & & 22 & 367 & & 25 \\
\hline 2 Chirurgie & 426 & 426 & 642 & 27 & 427 & 74 & 27 & 427 & 7425 & 254 & 425 & & 26 & 425 & & 28 \\
\hline 3 Gynoec/Obsterie & 530 & 529 & 95 & 31 & 531 & 175 & 28 & 530 & $0 \quad 435$ & 355 & 529 & & 25 & 526 & & 31 \\
\hline 4 Kindergeneeskunde & 448 & 3446 & 64 & 48 & 449 & 194 & 46 & 449 & 9443 & 434 & 449 & & 46 & 448 & & 49 \\
\hline 5 Neurologie & 349 & 346 & 163 & 49 & 348 & & 46 & 349 & 945 & 493 & 346 & & 44 & 342 & & 48 \\
\hline 7 Oogheelkunde & 428 & 3521 & 15 & 22 & 425 & 154 & 23 & 522 & . & $\cdot 5$ & 520 & & 22 & 426 & & 28 \\
\hline $8 \mathrm{KNO}$ & 446 & 446 & 644 & 41 & 317 & 74 & 41 & 445 & 5330 & 304 & 444 & & 36 & 442 & & 45 \\
\hline 9 Dermatologie & 335 & 337 & 731 & 19 & 334 & & 33 & 340 & 0327 & 273 & 340 & & 37 & 338 & & 40 \\
\hline & & & & & 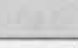 & & & & 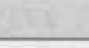 & & & & & & & \\
\hline$b_{0}$ & $N$ & - & 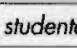 & 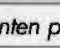 & 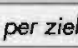 & ekenhu & & & & & & & & & & \\
\hline
\end{tabular}




\section{BIJLAGE 6}

Overzicht van de gemiddelde scores en standaarddeviaties onderscheiden naar domein en stageplaats (hoofdsłuk 9, studie 7)

\begin{tabular}{|c|c|c|c|c|c|c|c|c|c|c|c|c|c|}
\hline & & $\begin{array}{c}\text { Dome } \\
1 \\
\text { gem }\end{array}$ & inen & $\begin{array}{c}2 \\
\text { gem }\end{array}$ & sd & $\begin{array}{c}3 \\
\text { gem }\end{array}$ & sd & $\begin{array}{c}4 \\
g e m\end{array}$ & sd & $\begin{array}{c}5 \\
\text { gem }\end{array}$ & sd & $\begin{array}{c}7 \\
\text { gem }\end{array}$ & $s d$ \\
\hline \multirow[t]{4}{*}{ Int. geneesk. } & $z h i$ & 3.62 & .66 & 3.62 & .64 & 3.56 & .72 & 3.53 & .72 & 2.70 & .69 & 3.71 & .92 \\
\hline & zh 2 & 3.65 & .61 & 3.37 & .60 & 3.79 & .59 & 3.76 & .49 & 2.99 & .66 & 3.93 & .66 \\
\hline & $2 h 3$ & 3.64 & .76 & 3.38 & .67 & 4.15 & .52 & 3.70 & .64 & 3.21 & .61 & 4.26 & .70 \\
\hline & zh 4 & 3.75 & .67 & 3.44 & .46 & 3.40 & .64 & 3.31 & .59 & 2.97 & .58 & 3.80 & .61 \\
\hline \multirow[t]{4}{*}{ Chirurgie } & $z h l$ & 3.78 & .59 & 3.59 & .69 & 3.61 & .71 & 3.31 & .69 & 2.60 & .70 & 3.90 & .75 \\
\hline & zh 2 & 3.72 & .67 & 3.23 & 71 & 3.34 & .81 & 3.10 & .80 & 2.36 & .84 & 4.30 & .64 \\
\hline & xh 3 & 3.73 & .61 & 3.53 & .65 & 3.78 & .56 & 3.54 & .71 & 2.98 & .64 & 4.06 & .65 \\
\hline & zh 4 & 3.80 & .57 & 3.62 & .46 & 4.02 & .52 & 3.72 & .55 & 3.12 & .65 & 4.26 & .48 \\
\hline \multirow[t]{5}{*}{ Gyn/Obst. } & $z h 1$ & 3.83 & .61 & 3.84 & .64 & 3.98 & .62 & 3.58 & .67 & 3.04 & .71 & 3.78 & .91 \\
\hline & zh 2 & 3.95 & .45 & 3.76 & .70 & 3.89 & .60 & 3.46 & .76 & 2.96 & .80 & 4.34 & .67 \\
\hline & $\operatorname{ch} 3$ & 3.65 & .70 & 3.59 & .53 & 3.82 & .69 & 3.73 & .57 & 3.06 & .54 & 3.69 & .91 \\
\hline & zh 4 & 4.02 & .53 & 3.78 & .55 & 4.17 & .52 & 3.88 & .63 & 3.33 & .69 & 4.00 & .81 \\
\hline & zh 5 & 3.79 & .92 & 3.72 & .57 & 4.32 & .61 & 3.90 & .89 & 3.62 & .86 & 4. 12 & .82 \\
\hline \multirow[t]{4}{*}{ Kind. geneesk. } & $z h 1$ & 3.56 & .74 & 3.76 & .63 & 3.73 & .73 & 3.39 & .74 & 3.00 & .76 & 3.93 & .91 \\
\hline & th 2 & 3.56 & .74 & 3.72 & .65 & 4.04 & .85 & 3.43 & .80 & 3.18 & .85 & 4.17 & .77 \\
\hline & zh 3 & 3.62 & .68 & 3.28 & .64 & 3.63 & .82 & 2.99 & .89 & 2.65 & .92 & 3.25 & 1.11 \\
\hline & $z h 4$ & 3.51 & 78 & 3.49 & .60 & 4.30 & .53 & 4.05 & .69 & 3.38 & .74 & 4.27 & .77 \\
\hline \multirow[t]{3}{*}{ Neurologie } & $2 h 1$ & 3.21 & .90 & 3.66 & .63 & 3.73 & .72 & 3.27 & .87 & 2.97 & .83 & 3.39 & .97 \\
\hline & zh 2 & 3.32 & .81 & 3.93 & .70 & 4.05 & .66 & 3.45 & .72 & 2.83 & .80 & 3.92 & .85 \\
\hline & zh 3 & 3.18 & 71 & 3.71 & .65 & 4.13 & .58 & 3.80 & .63 & 3.23 & .81 & 3.76 & 1.10 \\
\hline \multirow[t]{5}{*}{ Oogh. kunde } & $x h 1$ & 3.07 & .75 & 3.79 & .71 & 4.12 & .63 & 3.37 & .77 & 2.72 & .85 & 3.81 & .87 \\
\hline & zh 2 & 3.33 & .82 & 3.93 & .59 & 3.99 & .90 & 3.57 & .88 & 3.04 & 1.14 & 4.00 & .64 \\
\hline & $z h 3$ & 3.46 & .81 & 3.37 & .74 & 4.02 & .42 & 3.46 & .42 & 2.99 & .76 & 4.17 & .78 \\
\hline & zh 4 & 3.27 & .73 & 3.44 & .63 & 4.50 & .45 & 3.81 & .83 & 2.98 & .89 & 4.27 & .78 \\
\hline & zh5 & 3.40 & .66 & 3.53 & .58 & 3.98 & .73 & 3.51 & .60 & 3.28 & .68 & 4.23 & .46 \\
\hline \multirow[t]{4}{*}{ KNO } & $z h$ l & 3.39 & .78 & 3.76 & .71 & 4.08 & .57 & 3.36 & .79 & 2.66 & .83 & 4.02 & .83 \\
\hline & zh 2 & 3.38 & .74 & 3.48 & .97 & 4.15 & .57 & 3.48 & .80 & 2.84 & .89 & 4.26 & 71 \\
\hline & th 3 & 3.48 & .84 & 2.85 & .94 & 4.02 & .77 & 3.41 & 1.01 & 3.36 & 1.01 & 3.77 & .90 \\
\hline & zh 4 & 3.31 & .79 & 3.32 & .80 & 4.16 & .51 & 3.35 & .76 & 2.87 & .75. & 3.77 & .89 \\
\hline \multirow[t]{3}{*}{ Dermatologie } & $z h 1$ & 3.06 & .84 & 3.90 & .56 & 4.45 & .48 & 3.75 & .63 & 3.03 & .78 & 4.32 & .59 \\
\hline & zh 2 & 3.17 & .72 & 3.73 & .67 & 4.38 & .52 & 3.91 & .66 & 3.22 & .80 & 4.70 & .48 \\
\hline & zh 3 & 3.34 & 1.12 & 3.78 & .80 & 4.52 & .51 & 3.80 & .93 & 3.39 & .93 & 4.50 & .57 \\
\hline
\end{tabular}




\section{Domeinen \\ $\begin{array}{llllll}8 & 9 & 10 & 11 & 13\end{array}$ \\ gem sd gem sd gem sd gem sd gem}

\begin{tabular}{ll|ll|lllllllll} 
Int. geneesk. 2 hl & 3.94 & .68 & 4.45 & .53 & 3.57 & .85 & 4.20 & .86 & 7.09 & .82
\end{tabular}

$\begin{array}{llllllllllll}\text { zh } 2 & 3.97 & .74 & 4.46 & .51 & 3.78 & .70 & 4.02 & .54 & 7.45 & .68\end{array}$

$\begin{array}{llllllllllll}\text { zh } 3 & 4.10 & .69 & 2.31 & 1.04 & 4.14 & .58 & 4.20 & .62 & 7.82 & .79\end{array}$

$\begin{array}{lllllllllll}z h 4 & 3.98 & .70 & 4.50 & .54 & 4.34 & .64 & 3.57 & .96 & 7.21 & .63\end{array}$

$\begin{array}{lllllllllllll}\text { Chirurgie } & z h & 3.84 & .71 & 4.11 & .67 & 3.88 & .67 & 4.05 & .75 & 7.17 & .81\end{array}$

$\begin{array}{lllllllllll}\text { zh } 2 & 3.94 & .70 & 3.21 & 1.08 & 4.09 & .74 & 3.84 & .92 & 7.33 & .89\end{array}$

\begin{tabular}{llllll|lllllll} 
zh 3 & 3.77 & .71 & 3.23 & .77 & 4.03 & .53 & 4.19 & .64 & 7.24 & .59
\end{tabular}

$\begin{array}{lllllllllll}\text { zh } 4 & 3.61 & .67 & 4.29 & .56 & 4.37 & .42 & 4.24 & .56 & 8.00 & .59\end{array}$

\begin{tabular}{ll|lllllll|llll} 
Gyn./Obst. & zh I & 3.98 & .65 & 4.44 & .62 & 3.82 & .84 & 4.36 & .73 & 7.26 & .93
\end{tabular}

$\begin{array}{lllllllllll}\text { zh } 2 & 3.77 & .76 & 3.89 & .85 & 4.22 & .70 & 4.14 & .84 & 7.60 & .82\end{array}$

\begin{tabular}{llllll|llllll} 
zh 3 & 3.51 & .87 & 4.11 & .70 & 4.16 & .55 & 4.25 & .60 & 7.56 & 1.00
\end{tabular}

$\begin{array}{lllllllllll}\text { zh } 4 & 3.95 & .74 & 3.24 & .84 & 4.07 & .87 & 4.25 & .67 & 7.94 & .75\end{array}$

$\begin{array}{lllllllllll}\text { zh } 5 & 3.94 & .74 & 3.67 & .77 & 3.60 & .86 & 4.50 & .54 & 8.42 & .91\end{array}$

$\begin{array}{lllllllllll}\text { Kind. geneesk. } z h 1 & 3.96 & .74 & 4.77 & .37 & 3.95 & .81 & 4.26 & .80 & 7.16 & 1.01\end{array}$

\begin{tabular}{l|lllllllllll} 
zh 2 & 3.93 & .81 & 4.79 & .36 & 4.48 & .57 & 4.09 & .77 & 7.70 & .88
\end{tabular}

$\begin{array}{llllllllllll}\text { zh } 3 & 3.74 & .77 & 2.69 & .71 & 4.64 & .42 & 4.24 & .80 & 6.53 & 1.13\end{array}$

$\begin{array}{llllllllllll}\text { zh } 4 & 4.22 & .81 & 4.81 & .35 & 4.53 & .55 & 4.44 & .69 & 7.75 & .67\end{array}$

$\begin{array}{llllllllllll}\text { Neurologie } & \text { zhl } & 3.97 & .71 & 4.60 & .50 & 4.09 & .77 & 3.97 & .90 & 7.20 & .80\end{array}$

$\begin{array}{llllllllllll}\text { zh } 2 & 3.71 & .88 & 4.69 & .36 & 4.59 & .50 & 4.22 & .73 & 7.64 & .86\end{array}$

$\begin{array}{llllllllllll}\text { zh } 3 & 4.32 & .51 & 3.71 & .81 & 4.23 & .63 & 4.13 & .81 & 7.73 & 1.03\end{array}$

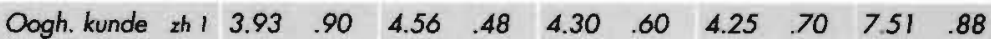

$\begin{array}{lllllllllll}\text { zh } 2 & 3.72 & 1.02 & 4.56 & .42 & 4.32 & .46 & 4.39 & .61 & 7.26 & 1.35\end{array}$

$\begin{array}{llllllllllll}\text { zh } 3 & 4.17 & .72 & 4.67 & .44 & 3.90 & .75 & 4.25 & .53 & 7.50 & .76\end{array}$

zh $4 \begin{array}{llllllllll}4.00 & .93 & 4.30 & .84 & 4.10 & .95 & 4.29 & 1.06 & 8.07 & .66\end{array}$

\begin{tabular}{l|lllllllllll} 
zh5 & 3.93 & .88 & 4.40 & .43 & 3.68 & .81 & 3.91 & 1.00 & 7.22 & 1.05
\end{tabular}

$\begin{array}{lllllllllllll}\text { KNO } & \text { zhl } & 3.34 & .82 & 4.73 & .38 & 3.84 & .80 & 4.23 & .75 & 7.64 & .76\end{array}$

\begin{tabular}{l|llllll|lllll} 
zh 2 & 3.10 & .93 & 4.79 & .35 & 3.77 & .99 & 4.31 & .66 & 7.66 & .69
\end{tabular}

$\begin{array}{llllllllllll}\text { th } 3 & 3.43 & .90 & 3.86 & 1.03 & 3.52 & 1.01 & 4.05 & .90 & 7.62 & .98\end{array}$

$\begin{array}{llllllllllll}\text { zh } 4 & 3.08 & .93 & 4.64 & .38 & 4.41 & .56 & 4.37 & .66 & 7.36 & .66\end{array}$

$\begin{array}{llllllllllll}\text { Dermatologie } z h l & 4.02 & .76 & 4.62 & .45 & 3.88 & .83 & 4.58 & .49 & 8.01 & .70\end{array}$

\begin{tabular}{l|llll|lllllll} 
zh 2 & 4.18 & .72 & 4.80 & .35 & 3.59 & .84 & 4.22 & .81 & 8.11 & .79
\end{tabular}

$\begin{array}{lllllllllll}\text { xh } 3 & 4.09 & .94 & 4.06 & 1.06 & 4.21 & .75 & 4.59 & .65 & 7.80 & 1.04\end{array}$ 


\section{BIJLAGE 7}

Overzicht van het aantal studenten dat gebruikt is voor betrouwbaarheidsstudie (studie 8)

\begin{tabular}{|c|c|c|c|c|c|}
\hline stage & $\begin{array}{c}\text { zieke } \\
1\end{array}$ & 2 & 3 & 4 & 5 \\
\hline Interne geneeskunde & 163 & 68 & 50 & 22 & - \\
\hline Chirurgie & 174 & 51 & 24 & 35 & - \\
\hline Gynaecologie/Obstetrie & 240 & 99 & 44 & 69 & 26 \\
\hline Kindergeneeskunde & 196 & 106 & 83 & 48 & - \\
\hline Neurologie & 115 & 78 & 45 & - & - \\
\hline Oogheelkunde & 131 & 18 & 12 & 15 & 15 \\
\hline KNO & 182 & 57 & 22 & 45 & - \\
\hline Dermatologie & 169 & 107 & 35 & - & - \\
\hline
\end{tabular}




\section{LITERATUUR}

Abrahamson, S. (1989). Myths and shibboleths in medical education. Teaching and learning in Medicine, vol. I, nr 1, 4-9.

Acherman, H. (1989). Kwaliteitsverbetering van hel onderwijs: de betekenis van de eerste ronde visitaties. Onderzoek van Onderwijs, februari, 3-6.

Albanese, M.A., Schuldt, S.S., Case, D.E. \& Brown, D. (1991). The validity of lecturer ratings by students and trained observers. Academic Medicine, 66, 26-28.

Association of American Medical colleges (1984). Physicians for the Twenty-First Century. Report of the Project Panel on the General Professional Education of the Physician and College Preparation for Medicine (GPEP-report). Washington.

Balla, J.I., Gibson, M. \& Biggs, J.B. (1989). Problems with curriculum implementation in in-service clinical education. Medical Education, 23, 282-289.

Basisfilosofie Medische Faculteit. Commissie voorbereiding medische faculteit (1972). Basisfilosofie achtsle medische faculteit. Medisch Contact, 33, 1-6.

Baumann, E.D. (1915). De dokter en de ontwikkeling der geneeskunde. Amsterdam: Meulenhoff.

Bentler, P.M. \& Bonett, D.G. (1980). Significance tests and goodness of fit in the analysis of covariance structures. Psychological Bulletin, 88, 588-606.

Berk, A.R. (1979). The construction of rating instruments for faculty evaluation. A review of methodological Issues. Journal of Higher Education, vol. 50, 5, 1137-172.

Berkel, H.J.M., van (1984). De diagnose van toetsvragen. Dissertatie Universiteit van Amsterdam. 
Bernards, J.A. (1983). Van coördinatie naar integratie. Ned Tiidschr Geneeskd, 27, 972-975.

Bie, D., de (1989). Een organisatorisch mirakel: de stage. HBOjournaal, februari, 46-48.

Bloom, B.S. (ed.) (1979). Taxonomy of educational objectives. Handbook I: Cognitive Domain. New York: Longman Green.

Borst-Eilers, E., Querido, A. \& Kock van Leeuwen, J.A.C., de (1989). Voorstel tot het invoeren van een algemene klinische vormingsperiode in het medisch onderwijscontinuüm. Zoetermeer: Ministerie van Onderwijs en Welenschappen.

Boshuizen, H.P.A. (1989). De ontwikkeling van medische expertise. Een cognitief-psychologische benadering. Dissertatie Rijksuniversiteit Limburg. Maastricht.

Bouhuijs, P.A.J. (1983). De ontwikkeling van het Praktisch Medisch Onderwijs in de Huisartspraktijk. Dissertatie Rijksuniversiteit Limburg. Maastricht.

Bouhuijs, P.A.J. (1990). Visitatie van de medische faculteiten. Medisch Contact, 35, 1033-1034.

Bouhuiis, P.A.J., Brouwer W. \& Mol, A.H.M. (1980). Praktisch Medisch Onderwijs in de Huisartspraktijk. Huisarts en Wetenschap, 23, 8-12.

Bouhuijs, P.A.J., Kok, W.G.C. \& Kolle L.F.J.Th.M. (1985). Affiliatie nu en in de toekomst. Medisch Contact, 40, 391-394.

Brennan, R.L. (1983). Elements of generalizability theory. lowa: American College Testing Program.

Bresters, D.W. (1990). Kwaliteitszorg in het Hoger Onderwijs. Bulletin Medisch Onderwiis, 9, 20-25.

Bruijn, E., de (1985). Onderzoekend leren over arbeid. Amsterdam: Stichting Centrum voor Onderwijsonderzoek.

Bureau Onderwijs Faculteit der Geneeskunde (1988). Onderwijsverslag 1988. Maastricht: Rijksuniversiteit Limburg. 
Bureau Onderwijs Faculteit der Geneeskunde (1991). Onderwijsverslag 1991. Maastricht: Rijksuniversiteit Limburg.

Byrne, N. \& Cohen, R. (1973). Observational study of clinical clerkship activities. Journal of Medical Education, 48, 919-927.

Cohen, P.A. (1981). Student ratings of instruction and student achievement: a meta-analysis of multisection validity studies. Review of Educational Research, 51, 281-309.

Colijn, A.W. \& Herbert, C.M. (1991). De co-assistent in het diepe. Medisch Contact, 35, 992-994.

Conrad, C.F. \& Blackburn, R.T. (1985). Program quality in higher education. In: Smart, J.C. (ed). Higher education: Handbook of theory and reserach. New York: Agathon Press, Inc, 238308.

Cooley, W.W. \& Bickel, W.E. (1986). Decision-Oriented Educational Research. Boston: Kluwer-Nijhoff Publishing.

Coombs, R.H. \& Boyle B.P. (1971). The transition to Medical School: Expectations versus Realities. In: Psychosocial Aspects of Medical training. Coombs, R.H. \& Vincent, C.E. (ed.). Springfield Illinois: Carles C. Thomas.

Cousins, J.B. \& Leitwood, K.A. (1986). Current empirical research on evaluation utilization. Review of Educational Research, 56, 331.364 .

Creemers, B.P.M. \& Hoeben W.Th.J.G. (ed.) (1992). Indicatoren van onderwijseffectiviteit. Groningen: Interuniversitair Centrum voor Onderwijsevaluatie en Onderwijseffectiviteit.

Creemers, B., Hoeben, W. \& Koops, K. (1983). De kwaliteit van het onderwijs. Groningen: Wolters-Noordhoff.

Crick, J.E. \& Brennan, R.L. (1983). Manual for GENOVA: A Generalized analyses Of Variance system. lowa City: ACT Technical Bulletin 43. American College Testing Program. 
Crocker, L., Llabre, M. \& Miller, M.D. (1988). The Generalizability of content validity ratings. Journal of Educational Measurement, 25, 4, 287-299.

Cronbach, L.J., Gleser, G.C., Nanda, H. \& Rajaratnam, N. (1972). The Dependability of behavioral measurements: generalizability for scores and profiles. New York: John Wiley and Sons.

Cronbach, L.J. \& Meehl, P.E. (1955). Construct validity in psychological tests. Psychological Bulletin, 52, 281-302.

Dalin, P. (1978). Limits to educational change. The Macmillan Press LTD.

Darling-Hammond, L., Wise, A.E. \& Pease, A.E. (1983). Teacher evaluation in the organisational context: a review of the literalure. Review of Educational Research, 53, 258-328.

Dokter, H.J. (1984). Verandering in doelstellingen ten behoeve van de opleiding tot basisarts in Rotterdam (1973-1983). Ned Tijdschr Geneeskd, 128, 1625-1628.

Dool, P.C., van den (1987). Beoordelen van stages. Specialistisch Bulletin. Arnhem: Centraal Instituut voor Toetsontwikkeling.

Dousma, T. \& Horsten A. (1980). Tentamineren. Onderwijskundige informatie voor het Hoger Onderwijs. Utrecht/Antwerpen: Het Spectrum.

Drenth, P.J.D. (1985). Inleiding in de testheorie. Deventer: Van Loghum Slaterus, B.V.

Drogendijk, A.C. (1977). De vitoefening van de genees- en heelkunde in het begin van de 19e eeuw te Enkhuizen. Ned Tijdschr Geneeskd, 121, 1966-1969.

Dunning, A.J. (1983). Dokteren aan de opleiding. Ned Tijdschr Geneeskd, 127, 637-638.

Dutrée, M.A. (1990). Mogelijkheden na het artsexamen. Utrecht: KNMG. 
Ebel, R.L. (1961). Must all tests be valid? American Psychologist, $16,640-647$.

Es, M., van \& Doef, S., van der (1990). "Dokter, zegt u het maar". Eisen te stellen aan een computersysteem om te leren diagnostiseren. Amsterdam: Stichting Centrum voor Onderwijsonderzoek.

Essed, G.G.M. (1987). Model stagewerkboek. Intern verslag. Maastricht: Rijksuniversiteit Limburg.

Essed, G.G.M. (1989). Verslag stagebeoordelingscommissie. Intern verslag. Maastricht: Rijkuniversiteit Limburg.

Eijkman, K.H. (1932). lets over de studie in de geneeskunde. Ned Tijdschr Geneeskd, 76, 1911-1914.

Feldman, K.A. (1977). Consistency and variability among college students in rating their teachers and courses: a review and analysis. Research Higher Education, 6, 223-274.

Festen, H. (1974). 125 jaar geneeskunst en maatschappij. Utrecht.

Fullan, M. (1982). The meaning of educational change. New York/London: Teachers College Press.

Fullan, M. \& Park, P. (1980). Curriculum Implementation: A foundafion Booklet. Ontario: Prepared for Ministery of Education.

Fullan, M. \& Pomfret, A. (1977). Research on Curriculum and Instruction Implementation. Review of Educational Research, 47, 335-397.

Gerritsma, J.G.M. \& Smal, J.A. (1974). Grensverschuivingen in het medisch onderwijs. Utrecht: Oosthoek, Scheltema \& Holkema.

Gerritsma, J.G.M. \& Smal, J.A. (1982). De werkwijze van huisarts en internist. Een vergelijkend anderzoek met behulp van een interactieve patiëntensimulatie. Dissertatie Rijksuniversiteit Utrecht. Utrecht: wetenschappelijke vitgeverij Bunge.

Giesbers, J.G.I. (1986). De rol van de faculleit bii de kwaliteitsbeheersing van het onderwijs. Universiteit en Hogeschool, 32, 284-296. 
Goldstein, G. \& Hersen, M. (ed.) (1984). Handbook of psychological assessment. New York: Pergamon Press.

Goodlad, S. (1984). Education for the professions. University Guildford: SRHE \& NFER-NELSON.

Goudsmit, J. (1978). Anderhalve eeuw dokteren aan de arts.

Geschiedenis van de medische opleiding in Nederland. Amsterdam: SUA.

Greep, J.M. (1979). Het onderwijs aan de medische faculteit te Maastricht. Medisch Contact, 34, 1107.1114.

Groot, A.D., de (1983). Is kwaliteit van onderwiis te beoordelen? In: Creemers, B., Hoeben, W. \& Koops, K. (ed.). De kwaliteif van onderwijs. Groningen: Wolters-Noordhoff.

Groot, A.D., de \& Naerssen, R.F., van (1969). Studietoetsen. Construeren, Afnemen, Analyseren deel 2. Den Haag: Mouton Publishers.

Gulden, J.W.J., van der (1984). Senior co-assistentschappen in Nederland. Een overzicht van de projectgroep Praktisch Klinisch Onderwijs. Medisch Contact, 36, 1141-1144.

Gulden, J.W.J., van der, Bulte, J.A. \& Metz, J.C.M. (1989). Vragen bij het onderwijs aan co-assistenten. Nederl Tijdschr Geneeskd, 133, 564-567.

Gijselaers, W.H. (1988). Kwaliteit van het onderwijs gemeten. Studies naar de betrouwbaarheid, validiteit en bruikbaarheid van studentoordelen. Dissertatie Rijksuniversiteit Limburg. Maastricht.

Gijselaers, W.H. \& Schmidt, H.G. (1990). The development and evaluation of a causal model of problem-based learning. In: Khattab, T., Schmidt, H., Nooman, Z. \& Ezzat, E. (ed.). Innovation in medical education: an evaluation of its present status. New York: Springer Publishing Company. 
Gijselaers, W.H. \& Wolfhagen, H.A.P. (1989). Implementing an method for quality control and quality assurance in clinical education. In: Bender, W., Hiemstra, R.J., Scherpbier, A.J.J.A. \& Zwierstra, R.P. (ed.) Teaching and assessing clinical competence. Groningen: Boekwerk Publications, TICTAC Foundation.

Hamilton, J.D. (1976). The MacMaster curriculum: a critique. British Medical Journal, 1, 1191-1196.

Harden, R.M. (1990). A fresh look at clinical teaching. In: Bender W., Hiemstra R.J., Scherpbier A.J.J.A. \& Zwierstra R.P (ed.). Teaching and assessing clinical comperence. Groningen: Boekwerk Publications, TICTAC Foundation.

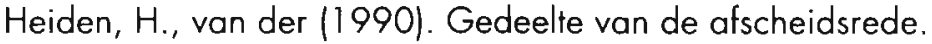
Bulletin Medisch Onderwijs, 9, 77.

Heller, K. (1978). Leistungsbeurteiling in der Schule. Heidelberg: Quelle \& Meyer.

Heringa, G.C. (1950). Open brief aan Prof Dr. J.J. van Loghem. Nederl Tiidschr Geneeskd 94, 271-273.

Heuvelmans, A.P.J.M. \& Verloop, N. (1986). Curriculumevaluatie, enige aandachtspunten en achtergronden. Specialistisch bulletin nr, 48. Arnhem: Centraal Instituut voor Toetsontwikkeling.

Heije, J.P. (1842). Over geneeskundige slaatsregeling. Archief voor geneeskunde.

Heijnen, G.W.H., Joosten, T.H. \& Vroeijenstijn, A.I. (ed.). Kwaliteitszorg, waarborg voor kwaliteit in het hoger onderwijs. Groningen: COWOG.

HOAK-nota. Hoger Onderwijs, Autonomie en Kwaliteit (1985). Zoetermeer: Ministerie van Onderwijs en Welenschappen. Staatsuitgeverij.

Hoogendam, I.J., Hulst, S.G.Th., Klatte, J.E., Schneider, H.J. \& Weel, F.A., van der (1984). Affiliatie toen, nu en in de toekomst. Syllabus symposium 25 mei 1984. 
HOOP-nota. Hoger Onderwijs en Onderzoek Plan (1987). Den Haag: Ministerie van Onderwijs en Wetenschappen. Staatsvitgeverij.

Hulsmans, R. e.a. (1989). Blokboek 3.4: het binnenste van buiten. Maastricht: Faculteit der Geneeskunde Rijksuniversiteit simburg.

Inspectie hoger onderwijs (1989). De Inspectie hoger onderwijs en haar meta-evaluatie taak binnen het stelsel van kwaliteitszorg in het hoger onderwijs. De Meern.

Interfacultair Overleg Geneeskunde (1967). Het interfacultaire overleg en de opleiding tot arts. Medisch Contact, 22, $1145-1152$.

Interfacultair Overleg Geneeskunde (1974). Raamplan 1974. Medisch Contact, 29, 1017-1021.

Irby, D.M. (1978). Clinical teacher effectiveness in medicine. Journal of Medical Education, 53, 808-815.

Irby, D.M. (1983). Evaluating Instruction in Medical Education. Journal of Medical Education, 58, 844-849.

Irby, D. \& Rakestraw, P. (1981). Evaluating clinical teaching in medicine. Journal of Medical Education, 56, 181-186.

Jansen, E.P.W.A.(1990). ISEK als instrument voor kwaliteitszorg. In: Heijnen, G.W.H., Joosten, T.H. \& Vroeijenstijn, A.I. (ed.). Kwaliteitszorg, waarborg voor kwaliteit in het hoger onderwijs. Groningen: COWOG.

Janssens, J.M.A.M. (1983). 'Ogen' doen Onderzoek. Een inleiding in de methoden van sociaal-wetenschappelijk onderzoek. Lisse: Swets \& Zeitlinger.

Jong, J.A., de (1982). "Ja maar miin mentor zegt ....". Harlingen: Flevodruk.

Jong, J.A., de, Laan, K., van der, Meertens, I. \& Sprong, S. (1984). Verslag onderzoeksfase 2 en 3 . Utrecht: Rijksuniversiteit Utrecht vakgroep onderwijskunde. 
Jong, T., de, Andel, J., van, Leiblum, M. \& Mirande, M.J.M. (1991). Courseware gids voor het hoger onderwijs. SUNCOO. Nijmegen: IOWO

Jöreskog, K.G. \& Sörbom, D. (1978). Analyses of Linear Structural Relationships by maximum likelihood and least squares methods. Version V. International Education Services.

Kane, M.T. (1982). The validity of licensure examinations. American Psychologist: vol. 37, 8, 911-918.

Kim, J. \& Mueller, C.W. (1982). Introduction to Factor Analysis. Beverly Hills, London: Sage publications.

Knegtmans, P.J. (1992). De Medische Faculteit Maastricht. Assen/Maastricht: Van Gorcum.

Koninklijke Nederlandse Maatschappii ter bevordering van de Geneeskunst [1951]. Rapport van de studiecommissie van de maatschappii inzake de Reorganisatie van het Hoger Onderwiis.

Kraan, H.F. \& Crijnen, A.A.M. (1987). The Maastricht Historytaking and advice checklist. Dissertatie Rijksuniversiteit Limburg. Amsterdam: Lundbeck.

Larson, J.R. [1979). The limited utility of factor analytic techniques for the study of implicit theories in student ratings of teacher behavior. American Educational Research Journal, 16, 201. 211.

Leske, G. \& Persico, J. (1984). Indicators of quality in cooperafive vocational education: a review and synthesis of research. St Paul Minnesota University.

Levine, H.G. (1978). Selecting evaluation instruments. In: Morgan and Irby (ed.). Evaluating clinical competence in the health professions. St Louis C.V. Hoofdstuk 4, 33-51.

Levinton, L.C. \& Hughes, E.F.X. (1981). Research on the utilization of evaluations. Evaluation Review, 5, 525-548.

Lieburg, M.J. (1978). Het Medisch onderwijs te Rotterdam (1467. 1967). Een kort historisch overzicht. Amsterdam: Rodopi N.V. 
Lieburg, M.J. (1984). Gilden, gestichten en gezondheidszorg. Vijftien opstellen over de medische stadsgeschiedenis van Rotterdam. Uitgegeven naar aanleiding van het 125 -jarig bestaan van de stichting ziekenfonds Rotterdam.

Lieburg, M.J. (1988). Bevorderlijk voor de kunst en nuttig voor de maatschappii. De geschiedenis van het Genootschap ter bevordering van Heel- en Verloskunde en van het Amsterdam Geneeskundig Genootschap. Amsterdam: Rodopi B.V.

Lindeboom, G.A. (1971). Inleiding tot de geschiedenis der geneeskunde. Haarlem: De Erven F. Bohn N.V.

Lindeboom, G.A. (1977). De artseneed in ons land voor 1865. Nederl Tiidschr Geneeskd 44, 1758-1761.

Linden, W.J. van der (1992). Indicatorensystemen voor de effectiviteit van onderwijs. In: Creemers, B.P.M., Hoeben, W.Th.J.G. (ed.). Indicatoren van onderwijseffectiviteit. Groningen: ICO.

Lissitz, R.W. \& Green, S.B. (1975). Effect of number of scale points on reliability. Journal of Applied Psychology, 60, 10-13

Livingston, S.A. \& Zieky, M.J. (1982). Passing Scores. A Manual for selting standards of performance on educational and occupational tests. Educational Testing Service.

Lodewick, L., Schmidt H.G. \& Lulofs, R. (1976). Het onderwijs in medische vaardigheden. Medisch Contact, 31, 775-777.

Loghem, J.J., van [1949]. Het aanzien van de geneeskundige stand. Nederl Tiidschr Geneeskd, 93, 4286-4289.

Loor, J.D., de (1988). Verbeter de geneeskunde, begin bij het onderwijs. Medisch Contact, 43, 1411-1414.

Lord, F.M. \& Novick, M.R. (1968). Statistical theories of mental test scores. Reading, MA: Addison-Wesly.

Mager, R.M. (1962). Preparing instructional objectives. Belmont.

Marsh, H.W. (1982). SEEQ: a reliable, valid and useful instrument for collecting students' evaluations of university teaching. British Journal of Educational Psychology, 52, 77-95. 
Marsh, H.W. (1984). Students' evaluations of university teaching: dimensionality, reliability, validity, porential biases, and utility. Journal of Educational Psychology, 76, 707-754.

Marsh, W.H. \& Hocevar, D. (1983). The factorial invariance of student evaluations of college teaching. American Educational Research Journal, 21, 341-366.

Mattern, W.D., Weinholtz, D. \& Friedman, C.P. (1983). The attending physician teacher. The New England Journal of Medicine, 308, $1129-1132$.

Mehrens, W.A. \& Lehman, I.V. (1984). Measurement and Evaluation in Education and Psychology. New York: The Dryden Press.

Mertens, F.J.H. (1981). Stages in een beroepsopleiding: het praktijkjaar in het Hoger Technisch Onderwijs. Dissertatie Universiteit van Amsterdam.

Metz, J.C.M. (1984). Medische competentie. Een onderzoek naar de betrouwbaarheid en de validiteit van het gestructureerde klinische examen. Dissertatie Katholieke Universiteit Nijmegen.

Metz, J.C.M., Bulte, J.A. \& Paridon, E.J.M. (1990). Basisarts: Bevoegd en bekwaam. Beleidsgericht onderzoek co-assistentschappen. Eindrapport. Zoetermeer: Ministerie Onderwijs en Wetenschappen.

Metz, J.C.M., Hermans, A.A.M. \& Lutterman, J.A. (1989). Een nieuw artsexamen in Nijmegen. Medisch Contact, 35, 1093-1096.

Metz, J.C.M. \& Scherpbier, A.J.J.A. (1989). Systematische vaardigheidstraining als voorbereiding op co-assistentschappen. Nederl Tijdschr Geneeskd, 133, 561-564.

Meijer, K. \& Lucassen, P. (1985). Effectieve stages in beroepsonderwiis. Stagiaires, docenten en begeleiders aan het woord. Den Haag: SVO.

Miller, G.E. (1961). Teaching and learning in Medical School. Cambridge, Massachusettes: Harvard University press. 
Moll, J. (1983). In Querido stijl. Bullefin Medisch Onderwijs, 2, 2-6.

Moll, J. \& Gerritsma, J.G.M. (ed.) (1983). Medisch onderwijs in discussie: luisteren naar huisartsen. Medisch Contact, 1, 25-28.

Moust, J.H.C., Bouhuijs, P.A.J. \& Schmidt, H.G. (1989). Probleemgestuurd leren. Hoger Onderwijs Reeks. Groningen: WoltersNoordhoff.

Nederlandsche Maatschappij ter bevordering der Geneeskunst (1909). Rapport. Nederl Tijschr Geneeskd, febr, 357-383.

Neufeld, V.R. \& Barrows, H.S. (1974). The "MacMaster philosophy": an approach to medical education. Journal of Medical Education, 49, 1040-1050.

Nijmegen (1970). Rapport van de commissie preklinische onderwijsfase. Uitgebracht project co-assistenten. Nijmegen: Faculteit der Geneeskunde.

Nijmegen (1982). Het curriculum 1982. Eindrapportage, voorbereid door de curriculumcommissie. Niimegen: Faculteit der Geneeskunde en Tandheelkunde.

Oakes, J. (1989). What educational indicators? The case for assessing the school context. Educational Evaluation and Policy Analysis, 11, 181-199.

Onderwijscommissie Faculteit der Geneeskunde Maastricht (1984). Nota praktische medische onderwijs in het viffde en zesde jaar. Maastricht: Rijksuniversiteit Limburg.

Onderwijscommissie Faculteit der Geneeskunde Maastricht (1987). Nota de Rode Draad III. Maastricht: Rijksuniversiteir Limburg.

Onderwijscommissie Faculteit der Geneeskunde Maastricht (1989). Nota de Rode Draad IV. Maastricht: Rijksuniversiteit Limburg.

Os, W., van (1987). Evaluatie van het hoger onderwijs. Hoger Onderwijs Reeks. Groningen: Wolters-Noordhoff.

Ostenk, J.H.A.M., Moerkamp T., Voncken E. \& Dool, P.C. van den (1990). Leerprocessen in stages. SCO-rapport 209. Amsterdam: Stichting Centrum voor Onderwijsonderzoek. 
Owens, T.R. \& Owen, S.K. (1982). Improving learning in the workplace. Journal of Cocperative Education, 57-6.5.

Parlett, M. \& Hamilton, D. (1977). Evaluation as, illumination: a new approach to the sludy of innovatory programs. In: Parleft, $M$. \& Dearden, G. Introduction to illuminative evaluation: studies in higher education.

Phaff, Ch. (1987). Het gebruik van simulatiepatienten in het vaardigheidsonderwijs. In: Dochy F.J. \& Luyk, S.J., van. Handboek vaardigheidsonderwijs. Lisse: Swets \& Zeilinger.

Postma, C.T. \& Metz, J.C.M. (1989). Het ALCO-schap in Nijmegen. Bulletin Medisch Onderwiis, 2, 68-71.

Prakken, J.R. (1977). Geschiedenis der geneeskunde. De strijdlustige chirurg Abraham Titsingh als veneroloog. Nederl Tiidschr Geneeskd, 121, 67-70.

Provus, M. (1971). Discrepancy evaluation: for educational program, improvement and assessment. Berkeley/California: McCutchan Pub.

Querido, A. (1970). Memorandum I: Verkenning der Problematiek. 's Gravenhage: Staatsuitgeverii.

Reinink, H.J. (1949). Het rapport van de staatscornmissie van het hoger onderwijs. Den Haag.

Richards, R. et al. (1987). Innovative schools for Health Personnel:

Report on Ten Schools Belonging to the Network of Community-oriented Educational Instifutions for Health sciences. WHO, rechnical report series. Switzerland: World Health Organization.

Roelink, H. (1980). De medische basisopleiding in een welvaartsstaat. Medisch Contact, 39, 1 199.1203.

Rommes, A.E.N. (1978). Scoring en beoordeling van prestaties op studietoetsen. Handboek voor de Onderwijspraktijk, afl. 3.

Ronteltap, C.F.M. (1990A). COO in medisch onderwijs vanuit cognitief perspectief. Bulletin Medisch Onderwiis, 1, 30-36. 
Ronteltap, C.F.M. (1990B). Toepassen en verwerven van kennis met behulp van de compuler. Bulletin Medisch Onderwijs, 2, 66-72.

Root, J., op het (1990). Aard en opzet van de stage Praktisch Medisch Onderwijs. Bulletin Medisch Onderwijs, 9, 4-13.

Rossum, H.J.M., van (1977). Medisch onderwijs: wegen zoeken en wegen. Dissertatie Rijksuniversiteit Groningen.

Rothman, A.I., Poldre P. \& Cohen, R. (1989). Evaluating clinical teachers for promotion. Academic Medicine, 64, 774-775.

Saris, W. \& Stronkhorst, H. (1984). Causal Modelling in Nonexperimental Research. Amsterdam: Sociometric Research Foundation.

Schaper, N. e.a (1992). Een enquête naar het onderwijs in de interne geneeskunde: algemene opzet onderzoek. Voordracht Gezond Onderwijs Congres Veldhoven november 1992.

Scheerens, J. (ed.) (1989). Evaluatie: om de kwaliteit van het onderwijs. Amsterdam/Lisse: Swets \& Zeitlinger B.V.

Scherpbier, A.J.J.A. (1988). The Ministerial consultation for medical education in Europe. Bulletin Medisch onderwijs, 9, 28-29.

Scherpbier, A.J.J.A. (1989). Een algemeen klinische vormingsperiode (1). Bulletin Medisch Onderwijs, 8, 131.

Scherpbier, A.J.J.A. (1990). Een algemeen klinische vormingsperiode (2). Bulletin Medisch Onderwiis, 1, 2-3.

Scherpbier, A.J.J.A. \& Koopal, S.A. (1990). Basisarts: Bevoegd en Bekwaam. Bulletin Medisch Onderwijs, 9, 99-101.

Scherpbier, A.J.J.A. \& Metz, J.C.M. (1989). Co-assistentschap: een stage? Bulletin Medisch Onderwijs, 2, 64-67.

Scherpbier, A.J.J.A. e.a. (1992). Resultaten van een enquête naar het onderwijs in de interne geneeskunde. Voordracht Gezond Onderwijs Congres Veldhoven november 1992. 
Schmidt, H.G. (1978). Probleem-georiënteerd onderwijs: leren aan de hand van problemen. Metamedica, 57, 4-16.

Schmidt, H.G. (1979). Leren met problemen, een inleiding in probleemgestuurd onderwijs. In: Vroon, A.G., et al. Handboek voor de onderwijspraktijk 1. Deventer: van Loghum Slaterus.

Schmidt, H.G. (1983). Problem-based learning. Rationale en description. Medical Education, 17, 11-16.

Schmidt, H.G., Neufeld, V.R., Nooman, Z.M. \& Ogunbode, T. (1991). Network of community-oriented educational institutions for the health sciences. Academic Medicine, 66, 259-263.

Schmidt, H.G., \& Volder, M.L, de (1984). Tutorials in problembased learning. A new direction in teaching the health profession. Assen: Van Gorcum.

Schretlen, I. (1981). Machteloosheid van de onderwijshervormers. Medisch Contact, 36, 1097-1 104.

Scriven, M.S. (1974). Pros and cons about goal free evaluation. Evaluation comment, 3, 1-4.

Shavelson, J.R. \& Webb, N.M. (1991). Generalizibility theory. Sage publications Inc.

Shavelson, R.J., Webb, N.M. \& Rowley, G.L. (1989). Generalizability theory. American Psychologist, 44, 992-932.

Sleegers, P. \& Bergen T. (1990). Deregulering en kwoliteitsbevordering van het onderwijs. Tijdschrift voor Lerarenopleiders, 11, 102-107.

Snellen-Balendong, H.A.M., Pollemans, M.C. \& Stalenhoef-Haling, B.F. (1984). Een analyse van het curriculum jaar $1 \mathrm{t} / \mathrm{m} 4$ $1981 / 1982$ van de Faculteit der Geneeskunde. Onderzoek van Onderwijs, interne reeks. Maastricht: Rijksuniversiteit Limburg.

Snoek, J. (1980). Stages in het beroepsonderwijs. In: Handboek Onderwijspraktijk, afl. 10. 
Stake, R.E. (1967). The countance of educational evaluation. Teachers College Record, 68, 532.540.

Starr, P. (1982). The social transformation of American Medicine. New York: Basic Books, Ic. Publishers.

Stillmann, P. et al. (1983). Effect of immediate student evaluations on a multi-instructor course. Journal of Medical Education, 58, 173-178.

Stritter, F.T., Hain, J.D. \& Grimes D.A. (1975). Clinical teaching reexamined. Journal of Medical Education, 50, 876-882.

Stufflebeam, D.L, Foley W.J., Gephart W.J., Guba, E.G., Hammond, R.L., Merriman, H.O. \& Provus, M.M. (1971). Evaluating evaluation and decisionmaking. Illinois: F.E. Peacock Publishers.

Swanborn, P.G. (1988). Schaaltechnieken. Meppel: Boom.

Sweeney, G.D., \& Mitchell, D.L.M. (1975). An introduction to the study of medicine: phase I of the MacMaster M.D. program. Journal of Medical Education, 50, 70-77.

Thorndike, R.L. (1982). Applied Psychometrics. Boston: Houghton Mifflin.

Tiddens, H.A., Willighagen, R.G.J.Y. Wijnen, W.H.F. (1975). Medisch Onderwijs in Ontwikkeling. Medisch Contact, 30, 1077-1085.

Tyler, R.W. (1950). Basic principles of curriculum and instruction. Chicago: University of Chicago Press.

Utrecht (1965). Nota over de artsopleiding. Utrecht: Faculteit der Geneeskunde.

Verbeek, H.A. (1982). Modernisering van het klinisch onderwijs. Nederl Tiidschr Geneeskd, 39, 1787-1790.

Vereniging van Samenwerkende Nederlandse Universiteiten (1990). Gids voor de Onderwiisvisitatie (herziene vitgave). Utrecht: VSNU. 
Vereniging van Samenwerkende Nederlandse Universiteiten (1992). Onderwijsvisitatie Geneeskunde en Gezondheidswetenschappen. Utrecht: VSNU.

Vleuten, C.P.M., van der (1989). Naar een rationeel systeem voor toetsing van studieprestaties in probleemgestuurd medisch onderwijs: studies naar betrouwbaarheid en validiteit van toetsen voor praktische vaardigheden Dissertatie Rijksuniversiteit Limburg. Maastricht.

Vleuten, C.P.M., van der \& Luyk, S.J., van (1988). Betrouwbaarheid van observatietoetsen voor praktische vaardigheden in het medisch onderwijs. Tijdschrift voor Onderwijsresearch, 13, 213-226.

Vleuten, C.P.M., van der \& Wijnen, W.H.F.W. (1991). Niets praktischer dan een goede theorie. Generaliseerbaarheidstheorie als instrument voor betrouwbaarheidsstudies. Bulletin Medisch Onderwijs, 10, 2-14.

Vries, B., de (1988). Het leven en de leer. Een studie naar de verbinding van leren en werken in de stage. Dissertatie Katholite ke Universiteit Nijmegen.

Vroeijenstijn, A.I. (1990). Autonomie en waarborg voor kwaliteit: keerzijden van dezelfde medaille. In: Heijnen, G.W.H., Joosten, T.H. \& Vroeijenstijn, A.I. (ed.). Kwaliteitszorg, waorborg voor kwaliteit in het hoger onderwijs. Groningen: COWOG.

Vroeijenstijn, A.I. (1991). De visitatiecommissie binnen het systeem van kwaliteitszorg. Tijdschrift voor Hoger Onderwijs, 1, 3241 .

Werff ren Bosch, J.J., van der (1973). Differentiatie in medisch onderwiip. Nederl Tiidschr Geneeskd, 117, 230-233.

Werkgroep Planning medisch wetenschappelijk onderwijs (1971). Memorandum II: Beschouwingen over enkele elementen die van betekenis zijn bij het ontwikkelen van een planningsmechanisme voor medisch wetenschappelijk onderwijs.

's Gravenhage: Staatsuitgeverii. 
Werkgroep Planning medisch wetenschappelijk onderwijs (1973). Memorandum III: Enkele aspecten van de samenhang tussen de gezondheidsstructuur en het medisch wetenschappeliik onderwijs. 's Gravenhage: Staatsuitgeverij.

Wiegersma, S. (1989). Innovatie van het hoger onderwiis. Hoger onderwijs reeks. Groningen: Wolters-Noordhoff.

Wittrock, M.C. (1986). Handbook of Research on Teaching. New York: MacMillan.

Wolfhagen, H.A.P. \& Essed G.G.M. (1989). Programmaevaluatie klinisch co-assistentschappen 1989. Maastricht. Intern rapport Faculteit der Geneeskunde. Riiksuniversiteit Limburg.

Wolfhagen, H.A.P. \& Gijselaers, W.M. (1990). Kwaliteit van coassistentschappen bepaald. Medisch Contact, 19, 621-623.

Wolthagen, H.A.P., Gijselaers, W.H., Stalenhoef, B.F. \& Essed, G.G.M. (1989). Programma-evaluatie van de co-assistentschappen. Bulletin Medisch Onderwijs, 8, 126-130.

Wolfhagen, H.A.P., Essed G.G.M., Nieuwland, R.K.M \& Wetten, A.F.A., van (1992). De begeleiding tijdens co-assistentschappen nader bekeken. In: Vleuten, C.P.M., van der, Scherpbier, A.J.J.A. \& Polllemans, M.C. (ed.). Congresboek Gezondonderwijs 1991. Boom: Staffleu.

Wolfhagen, H.A.P., Vleuten, C.P.M., van der, Höweler, C.J. \& Essed G.G.M. (1992). Een aanzet tot de formulering van eindtermen in een stage. In: Vleuten, C.P.M., van der, Scherpbier, A.J.J.A. \& Polllemans, M.C. (ed.). Congresboek Gezondonderwijs 1991. Boom: Staffleu.

World Federation for Medical Education (1989). The Edinburgh Declaration. Edinburght. Ann. Community-Oriented Education, $2,111.113$.

Wiinen, W.H.F.W. (1971). Onder of Boven de Maat. Amsterdam: Swers \& Zeilinger.

Wijnen, W.H.T.W. (1977). Toetsen en beslissen. Losbladig Onderwijskundig Lexicon, MK 1600, 1-14. Alpen aan den Rijn: Samson 
Zwieten, J., van (1985). Uit ervaring, theorie en praktiik over de leermogelijkheden van leerarbeidsplaatsen. Amsterdam: Stichting Centrum voor Onderwijsonderzoek. 


\section{CURRICULUM VITAE}

Ineke Wolfhagen werd geboren op 30 maart 1957 te Roermond. Zij voltooide haar HAVO-opleiding in 1974 aan de Scholengemeenschap "Sint Ursula" te Roermond. Vervolgens bezocht zij de Pedagogische Academie "Dr. van Gils" te Roermond, waar ze in 1977 haar diploma volledig bevoegd onderwijzeres behaalde. In datzelfde jaar startte zij de studie pedagogiek aan de Katholieke Universiteit te Nijmegen met als afstudeerrichting Interdisciplinaire Onderwijskunde. Deze studie werd in 1983 voltooid.

In de periode 1983-1988 was zij als onderwijskundige verbonden aan het Centraal Instituut voor Toetsontwikkeling (CITO) te Arnhem. Sedert 1988 is zii als universitair docent verbonden aan de vakgroep Onderwijsontwikkeling en Onderwijsresearch van de Rijksuniversiteit Limburg. Haar speciale aandachtsgebied is de programmaevaluatie van het medisch onderwijs. Daarnaast is zij sinds mei 1992 redactiesecretaris van de Hoger Onderwijs Reeks. 

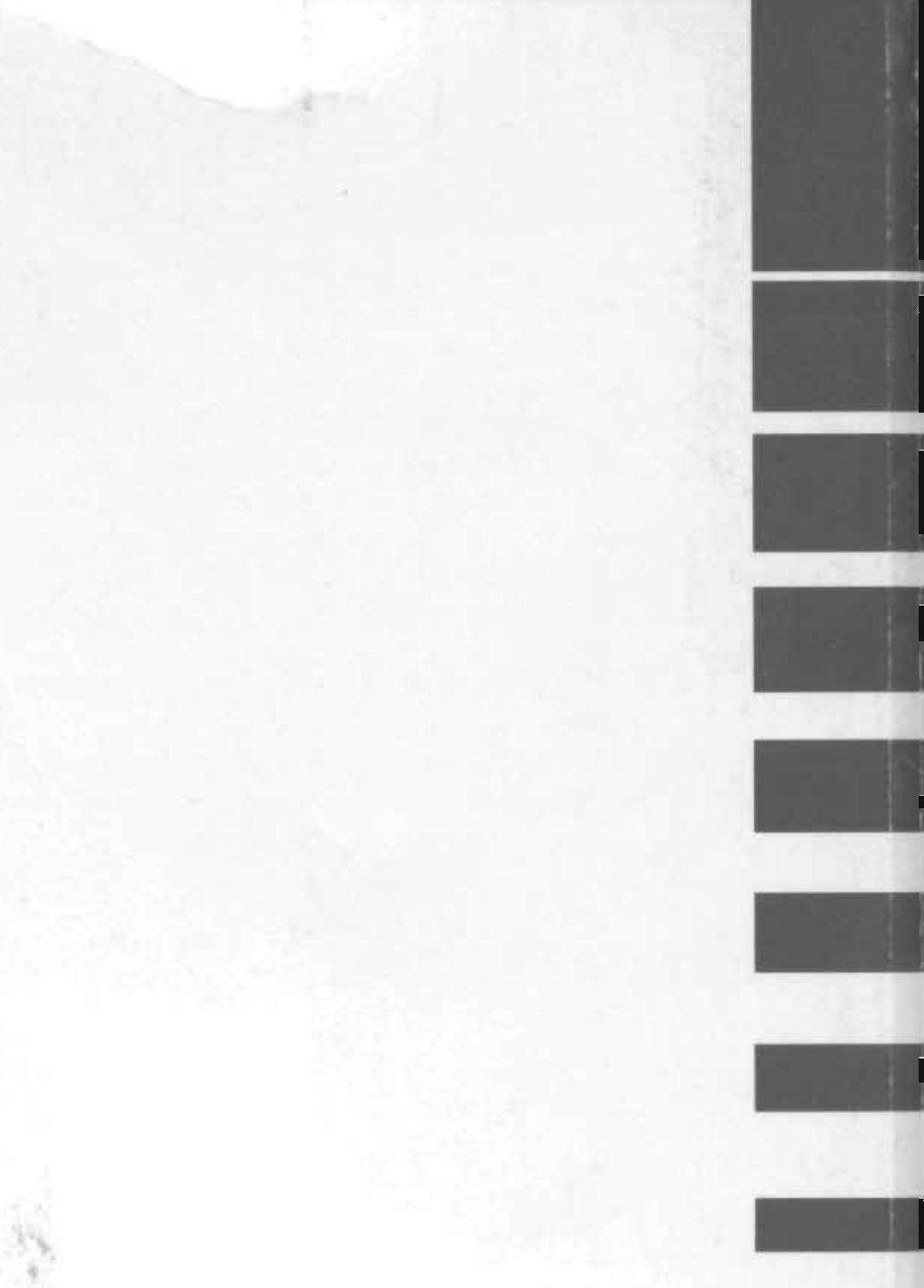

Datamyse / Universitaire Pers Maastricht ISBN $90-5278 \cdot 052 \cdot 8$ 